


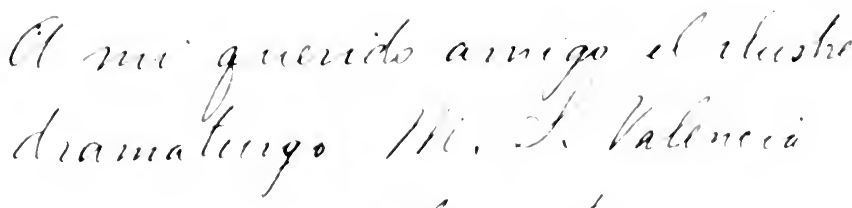

$$
\begin{aligned}
& \text { st a ullow. }
\end{aligned}
$$

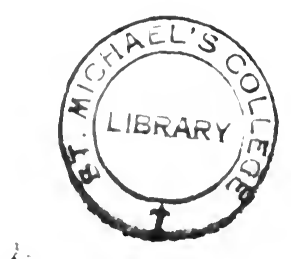







THE REVIVAL

OF SCHOLASTIC PHILOSOPHY 



\section{THE REVIVAL \\ OF SCHOLASTIC PHILOSOPHY \\ IN TIIE \\ NINETEENTH CENTURY}

III

JOSEPII LOUIS PERRIER, PH.D.

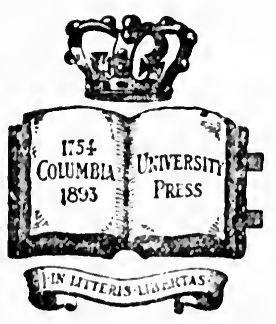

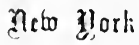

THE COIUMBIA UNIVERSITY PRESS

1909

All, rishts reseried 


\section{Copyright, 1909}

\section{By The Columbia University Press}

Printed from type March, Igo9 


\section{PREFACE}

The present work eonsists of two parts, the first of which may be described as definitional; the second, as historical.

The first part (Chapters I to VIII) is not intended to be a complete course of Seholastic philosophy. I limit myself to an exposition and a discussion of those principles of Scholasticism, a knowledge of which is indispensable to an understanding of the Scholastic revival. For an adequate knowledge of Scholastic philosophy, I would refor my readers to the masterly expositions of Urríburu, Mercier, and the Jesuits of Stonyhurst. 'The shorter treatises of Ginebra and Pécsi are also excellent.

In the historical part, I have divided the speculative world into races rather than into political divisions. I have thus included German Austria in the chapter on Germany and devoted a separate section to Hungary. I have likewise studied south American republies in connection with the neo-sicholastic movement in spain. It is into races, rather than into arbitrary tracts of land, that the world is divided. In spite of the ridiculous principle we call the Monroe doctrine, South American nations are and will always be esontially Spanish. With spain they speak, they think and they pray. They regard us as strangers, sometimes as barbarians. They amphatically refuse to acept the protection we would force upon them.

In completing this second part, I have derived considerable help from the following works:

Gonzale\%: Historin de la Filosofin.

Blanc's II istoire de la Philosophie et particulierement de la

Philosophie contemporaine.

Besse's lleut entres du mourement thomiste.

(iome\% l\%quierdo's II istoria de la Filosofia del siglo $X I A$, 
Ferreira-Deusdado's La Philosophie thomiste en Portugal, van Becelaere's la Philosophie en Amérique,

Garcia's Tomismo y Neolomismo,

Valverde 'Tellez's historieal works.

I tender my sincere thanks to the friends who have assisted me in the preparation of this book. In partieular, I acknowlelge my obligation to Professor John Dewey, of Columbia University.

New York, April, 1908.

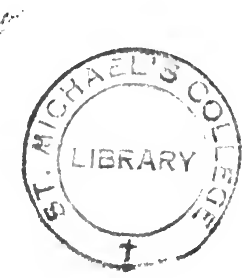

FEB 2: 


\section{CONTENTS}

INTROHCLTION

\section{('HAPTIER I}

What is ficholastic Pinosophy?

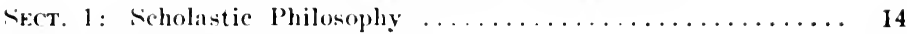

Sect. 2: Neo-sicholastic Philosophy ................ 34

('IAP'TER II

Sinolaste Logic

('HAP'TKR III

Soholaste Metaphysics

Sr.ct. 1: Existence of Metaphysies ................ 46

SECT. 2: Scholastic Theory of Act and Potency .......... 49

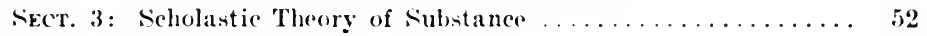

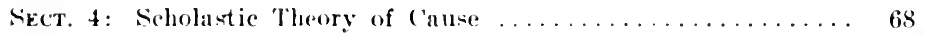

('IIAPTER W'

SCHOLASTIC Cosmologi

SEcT. 1: Chief llypotheses as to the constitution of Matter .... s2

Sect. 2: Nature and Properties of P'rimordial Matter ....... 86

SEcr. 3: Nature and Properties of the Substantial Form . . . . . 95.

SFot. 4: Modern Ficience and the Constitution of Matter ..... 100

\section{('IAAPTER V \\ SCHOLAstic Psychology}

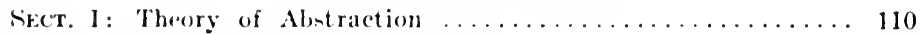

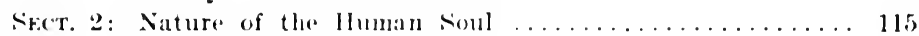

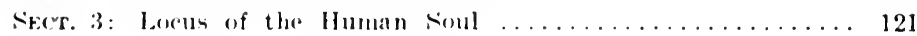

\section{('HAP'TER V'I}

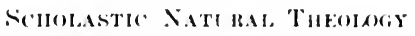

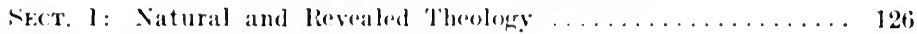

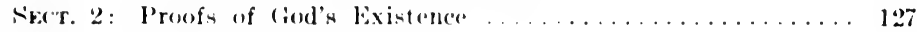

Sict. 3: Attributen of fiod .................... 131

('IAP'TER VII

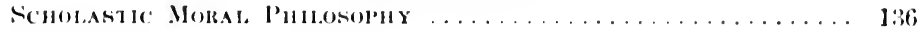

C'HAP'TER VIII

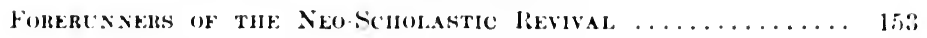




\section{viii}

\section{CIIAPTER IX}

The Neo-Scholastic Revival in Itam $\ldots \ldots \ldots \ldots \ldots \ldots \ldots \ldots$

('IIAP'TER X

The Neo-Scholastic Revival in Spaix, Pobtugal and Spanish America

SEct. 1: The Neo-Scholastic Revival in Spain ........... 174

Sect. 2: The Neo-Scholastic Revival in Portugal . . . . . . . . . 183

Sect. 3: The Neo-Seholastic Revival in Mexico ............ 18.7

Sect. 4: The Neo-Scholastic Revival in South America ....... 191

CHAPTER XI

The Neo-Scholastic Reviva, i. (immaxy avi distria . . . . 196 CHAPTER XII

The Neo-Scholastic Revival ix Frince . . . . . . . . . . . . . 203

CIIAPTER TIII

The Neo-Scholastic Revival in Belgili $\ldots \ldots \ldots \ldots \ldots \ldots \ldots$. 15 )

CHAPTER XIV

The Neo-Scholastic Reviral in other European Countries

Secr. 1: The Neo-Scholastic Revival in Hungary, Bohemia and the Netherlands ................... 224

SECT. 2: The Neo-Scholastic Revival in England ........... 228

CHAPTER XV

The Neo-Scholastic Revivat, in the Cxited States axi Canada

Sect. 1: The Neo-Sicholastic Revival in the Inited States . . . 23:

Secr. 2: The Neo-Scholastic Revival in Canada ............. 244

BIBLIOGRAPHY OF THE NEO-SCHOLASTIC IITERATURE . 249 


\section{INTRODECTION}

One of the movements that have excited the interest of the world of thought in the nineteenth eentury has been the revival of Sebolasticism. The philosophy of the Middle Ages had been, for centuries past, buried in deepest oblivion. It had been considered inconsistent with the development of natural science; and all, philosophers as well as scientists, deemed it dead-a most fitting end. It appeared to us, in the dim light of history, as an ill-shapen monster, which had wandered in the darkness of night, amid philters and mysterious juices, during the ages in which men seriously considered alchemy and the philosopher's stone. But the monster, thought we, had disappeared forever at the light of modern discoveries, like the ill-omened bird of night, which eannot abide the rays of the morning sinn.

suddenly, to the astonishment of all, Scholasticism has awaked from its slumber. It has appeared again in the face of the world, has been accepted by great minds, has been expounded and defended by powerful writers, and has given rise to a great number of interesting philosophical works. Its admirers have even tried, not only to prove its congruity with modern scientific results, but to show that it is the only system eapable of explaining them.

As was to be expected, such a revival has met with the most sovere criticism. Friedrich Paulsen, in the introduction to his work Immanuel Kant, comparing Scholasticism with the Kantian sretem, expreseses himself thus:

"If Sholastic philosophy is at present experiencing a kind of revival in the school of ('atholicism, this is due, not so much to its own inner vitality as to its supposed fitness to serve an ecclesiastical political system, which, through the favor of eircumstances,-pationtin lori et stultitu hominum, an old Luth- 
eran would say,-has attained again in our time to unexpected power. Moreover, there still remains the question whether continuance of existence is in general something of which a philosophy ean boast. Perhaps fruitfulness is a better characteristic and this the Kantian philosophy shows; it still gives rise to new systems of thought. Thomism, on the contrary, though of course a great achievement for its own time, yields to-day nothing except unfruitful repetitions. It does not set free the spirit, it enslaves it, which of course is just its intention."

In close connection with Paulsen's view stands the thesis recently defended by Mr. Picavet in his famous Esquisse d'une histoire générale et comparée des civilisations médiévales. For him, Scholastic philosophy and the body of Christian dogmas are identical; the existence of God and the immortality of the soul are the essential Scholastic doctrines. Accordingly, he seems disposed to widen the field of Scholasticism, and to include within its limits a certain number of men whom neoScholastics will probably be loath to welcome as brethren. Not only does he admit Deseartes and Locke, ${ }^{2}$ but also Rousseau and Voltaire. $^{3}$ He even feels inclined to add to his heterogeneous list the name of Robespierre. ${ }^{4}$ But the man to whom he directs our attention with the greatest insistence, whom he regards as a direct offspring of the Middle Ages, as a man " in the theological period still, a Christian, a Lutheran, a pietist, a Scholastic," is Immanuel Kant. ${ }^{5}$

Why not? Kant quotes the Bible; he develops the proof of the existence of God from final eauses, and he is fond of repeating the Hebrew meaning-God with us-of his name Immanuel. ${ }^{5}$ In religion, Kant is a supporter of the Christian doctrine; he advoeates the existence of free-will; when he under-

'Immanuel Kant, p. 11.

${ }^{2}$ Esquisse d'une histoire génerale et comparée des civilisations medievales, p. 239.

Itid., p. 240.

- Ibid., p. 247.

slbid., p. 241.

"Ibid., p. 242. 
takes his Critique of Pure Reason, he is morally certain of the existence of God and of another life. ${ }^{7}$ It is in Christian terms that he expresses the final conclusion he reaches, denouncing, as believers do, the insufficieney of speculative reason and ending with an act of faith." In one word, Kant's work is an apologetic and may be compared to St. Thomas's Summa contra Gentiles. "Son ceurre rappelle celle des apologistes, en particulier de saint Thomas qui, dans la Somme contre les Gentils, veut amener au catholicisme, avee le seul appui de la raison, les mahométans, les juifs, les hérétiques de toutes les muances. De même liant s'alresse aux athées et aux matérialistes, aux panthéistes at aux fatalistes, aux incrédules et aux esprits forts."

The impulse given to neo-Thomism by Leo XIII is for Pieavet as well as for Paulsen, primarily and essentially a politieal affair. In his survey of the progress of neo-Scholasticism in the different countries of Europe and in Ameriea, it is not a speculative, but a political point of view that is invariably taken. The acceptance of Thomistic speculation in Belgium is given as one of the causes of the political sucesses obtained by Catholies since 1884. The strength of the Catholic party in Germany is also insisted upon. In connection with the Thomistic revival, Picavet quotes the fact that Prince Bismarek was constrained to abandon the Kulturkampf, that the Catholic minority, giving toasts to the pope and to the emperor, becomes more powerful every day. ${ }^{10}$

Finally, it propos of neo-Scholasticism in the United States, Picavet limits himself to considerations about the growing political and soeial influence of ('atholies in this country, and speaks of Bishop Ireland, and of the condemnation of the propositions known as Americanism and contained in the "Life of Father Hecker."

'Ibid., p. 242.

"Ibial., p. 24ti.

- Ibid., P. 24li.

"Ibid., p. 281 .

"Ilid., Pए. 290292. 
In short, Pieavet and Paulsen are unanimous in regarding Scholasticism as a religious and political affair; but, whereas Paulsen restriets the denotation of the word to Roman Catholieism, Picavet seems ready to enlarge its usual aceeptation, so as to make it embrace all Christian denominations. Picavet, however, would probably distinguish between Protestant and Catholic Scholasticism, so that his views as to the revival of Thomism would closely resemble Paulsen's own views.

There are two points which both authors elearly distinguish and strongly insist upon:

1. The essential agreement of the Thomistic philosophical doctrine with the body of Catholic dogmas.

2. The political significance of the Scholastic revival.

We will presently examine each of these points separately.

With regard to the first, we may readily admit that there is a great deal of truth in the foregoing theories. That the immediate cause of the revival of Thomism is its real or apparent harmony with the body of theological doctrines of the Catholie Church, it would be vain to deny. The following considerations will dispel any doubt that might exist on this point:

1. The greater number of modern philosophical systems have been condemned by Catholic theologians as opposed to revealed truth, and many among the leaders of modern thought have seen their works placed on the Index Librorum Prohibitorum. We find in the Index the names of Descartes, Malebranche, Locke, Condillac, Ifume, Kant, Rosmini, ete.

2. The neo-Scholastic movement has been encouraged, since its very birth, by the visible head of the Catholic Church, Pope Iseo XIII. In the encyelieal Inscrutabile Dei Consilio, published in 18\%8, in the encyclieal Eterni Patris (1879), in briefs relating to the foundation of the Roman Academy of St. Thomas and of the Institut Supérieur de Philosophie of Louvain, as well as in many other writings, Leo XIII has promoted the study of the great medixval philosophers, and in particular of St. Thomas Aquinas. 
3. As will be seen in the part of this work dealing with the history of neo-Scholasticism, all the great writers of this school belong to the Roman Catholic faith; most of them, in fact, are Catholic priests.

4. Moreover, St. Thomas Aquinas, who has always been regarded by ('atholies as the greatest theologian, whose summa Theologica is, and has always been, widely studied in ecclesiastical institutions, is the very philosopher to whom the new movement unanimously adheres. It is his doctrine that is expounded and commented upon in all neo-Scholastic treatises of philosophy. The two words Thomism and Scholasticism have become synonymous; periodicals founded to foster the revival of mediaval thought have been called Dirus Thomas and Revue Thomiste; and, in countries in which neo-Scholasticism has been most flourishing, St. Thomas is considered as the patron saint of philosophers.

The element of truth we are actually considering ought not, however, to make us suppose that the Catholic faith and the Thomistic principles are necesarily bound together. The philosophy of Plato and St. Augustine has been the oflicial philosophy of the church for more than eight hundred years. And, at the appearance of St. Thomass works, a strong eurrent of opposition to his teaching arose within the Church, nay within his own order, and gave birth to Iuns Scotus's philosophy, which differs so widely from 'Thomism that it has been said that there is not a single proposition in the works of the Angelie Doctor which has not been controverted by his subtle rival. And despite this fact, scotists profess to be as decidedly orthodox as their opponents, and, quite reently, Séerétan has even gone so far as to defend the thesis that the philosophy of Inus scotus is more in harmony with the spirit of Christianity than the traditional 'Thomistic philosophy. ${ }^{12}$ 'This seems to be also the view of Mr. John I)ewey. ${ }^{13}$

\footnotetext{
${ }^{12}$ ('f. Secretan, La Restauration du Thomisme, Rerue Philosophique, Vol. 18, p. $6.4 \mathrm{tr}$.

${ }^{23}$ ('f. the article: Belief and Realities, Philos. Re'., March, 1906.
} 
In modern times, Catholic writers have repeatedly formulated systems of thought which can be harmonized without too much difficulty with Catholic dogmas. Descartes, Malebranche, Rosmini, Cousin, Lamennais, De Bonald, have had within the Church itself numerous and illustrious disciples. Cousin's eclecticism has been for many years the official philosophy of a great number of Catholic institutions. Finally, in our own day, despite the revival of 'Thomism and the encyclical of Leo XIII, many of the orthodox, many ecclesiastics, do not think it amiss to adhere to philosophical systems which, in their principles and in their methods, are widely divergent from the Thomistic doctrine. Suffice it to mention the adherence of so many members of the French elergy to the revival of Kantism, and the enthusiasm with which some eminent Catholics of the same country have welcomed the appearance of Pragmatism.

Passing now to the political significance of the Scholastic revival, we will certainly concede that all the beliefs of a nation have a more or less direct influence upon its political institutions. A nation is a great whole, a great social unit, whose spirit is gradually formed by the conjoint influence of all the elements at work among the race, is at the same time the effect and the cause of the educational system, of the philosophy, of the literature of the nation, of all and each one of the channels through which her very blood and life flows.

The political influence of the philosopher should not, however, be exaggerated. It is at once obvious that a man who pretends to rise above mediocrity in any special field must concentrate thereto the energies of his whole life. He who wants to become a great philosopher must not be anything else. A few neo-Scholastics have entered the political arena; but, in so doing, they have so little obeyed the spirit of neo-Scholasticism that their course of action has been deplored by the Scholastics themselves. A man who has been second to none in his perfect grasping of the intentions of Leo XIII, Cardinal Gonzalez, 
expressed his sincere regret when Orti y Lara abandoned the field of philosophy to devote his talent to public affairs. ${ }^{14}$

The fitnes: of scholasticism to sorve the Catholie ecelesiastical political system, which-pretientia Dei et stultitia hominumI'aulsen regards as the only eamse of the revival of Mediaval philosophy, cannot thus be its only cause, nor that which possesses the greatest significance in the history of human thought. Besides the fact that the Chureh can aceommodate itself to all forms of govermment, and that there is therefore no (atholic ecclesiastical political system-as was pointed out by Mr. Domet de Vorges in answer to Pieavet ${ }^{15}$-it must be borne in mind that Sicholasticism is, above all, a philosophy and must he characterized as a philosophy.

The question of the cause of the neo-Scholastic revival leads at once to the remark that it is not always possible to find in the general conditions of any given period a definite and neeessary cause for all the events which form its history. Historical facts are often eonnected with unimportant, even trivial occurrences, so that it sometimes seems to the thoughtful man that chance governs the world. Would ('harles I have been executed if young Oliver ('romwoll had not been prevented from embarking for Amorica: Would our civil war have taken place if Henry ('lay had defeated Polk in the elections of 184t? Would there have been a neo-sicholastic revival if sinneverino had died when a young man and Lo SIII had not been elected to sueceed Pius IX in the papal ser? 'These are questions to which I would not dare give an answer.

The conditions of the possibility of an event must undoubtelly exist at the moment in which the avent occurs: but there must also be found an oreasional cause which may fail to appear. in which ase the eonditions of possibility may remain indefinitely in the same state. without any artual orecurrence of the erent.

1" Cf. Conzale\%, Historia de la libosoffa, Vol. 4, p. 4ti2.

13 In La philosophie medievale dapres M. Piouvet, Rer. de Philos., $190 k$. 
If we thus understand by the cause of the revival of Scholasticism the conditions which made it possible, we will find it bound with a principle which is essential to the Catholic beliefs, and, more distinctly than any other, separates the Roman Church from all Protestant sects: the principle of the unity and immutability of truth. A brief exposition of St. Thomas's doctrine on this point will not be out of place here.

Truth, St. Thomas teaches, may be considered with regard to our mind or with regard to things. With regard to our mind, truth is in one sense multiple, because it consists in the conformity of our knowledge with the object, and there are as many conformities as there are objects. With regard to things, truth is also in one sense multiple, because the truth of a thing is the very essence of the thing, and there are as many essences as there are things. But truth is also one, in so far as the essence of a thing is eternal and necessary, so that of one thing there can be but one truth.

As regards the other property of truth, its immutability, St. Thomas teaches that truth considered in things is immutable in so far as the essential characteristies are concerned, and mutable only in the accidental elements. Truth, considered with regard to our mind, is essentially immutable and aceidentally mutable. It is mutable only in the sense that our mind may pass from error to truth. It is essentially immutable, because it is regulated by the truth of things, which is immutable. With regard to the Divine Mind, truth is essentially one and immutable. ${ }^{16}$

This theory as to the nature of truth has been always strongly defencled by Catholic writers. They have been unanimous in regarding internal change in a body of doctrine as an infallible sign of error. It is upon the variations that had taken place in Protestant creeds that Bossuet based his immortal Histoire des Variations. You change, said he to Protestants, therefore you err.

${ }^{16}$ (f. Thomas Aquinas, Summa Theol., (2. 16, art. 5-8. 
Now, this fundamental principle of the Catholic Church is essentially opposed to the individualism which has inspired modern philosophy. Since Descartes to our day, philosophy has not been considered as a stereotyped body of truths. Each philosopher has been the author of a particular system of thought, and there have thus arisen innumerable doctrines, often opposed, sometimes contradictory to one another. This result is essentially antipathetic to a Catholic mind and incompatible with the principle of the unity of truth. A Catholic will no doubt admit that the principle of authority in philosophy is of secondary importance. He will emphatically assert as well as any one else, that every man must think with his own head; but, as he maintains truth to be one and all human minds to be endowed with a faculty of reasoning which works in the sime way in all of us, he will assert that we must necessarily reach identical ronclusions in our philosophical investigations.

We need but to open the works of the early neo-Thomists to he convinced that they regard the ephemeral character of modern systems as the strongest argument in favor of scholastieism. cornoldi's Lectures on Scholastic Philosophy are especially interesting.

"There is such a variety and contradiction in the doctrines taught (in modern philosophy)," says he, "that one cannot adhere to one system without openly denying the others. The diversity which reigns in modern schools is so general that two professors can hardly be foumd, even in the same college, agreeing, I will not ray upon the whole field of philosophy, but simply upon its fundamental principles. Moreover, it becomes impossible to teach the same doctrine for ten years. There is a continunus change and contradiction. From the center of the circle, which is one and indivisible, an infinite number of radii may proceed and extend in all directions. In all fields of human speculation, innumerable errors may likewise be found to diverge more and more from the one and indivisible truth." ${ }^{\prime \prime}$

And after having shown the diversity which reigns among

"Cornoldi, Isecons de Philosophic Scolastique, p. 3. 
modern systems, Cornoldi appeals to the twenty centuries during which Scholasticism was taught, to prove that this system, and this system alone, can give an adequate explanation of scientific discoveries. ${ }^{18}$

Now, truth being one and immutable, philosophy, which may be described as a rational expression of the truth of things, will also be one and immutable. And if there arise several philosophical systems, one of them at most will be true.

The difficulty now will evidently lie in finding out the true philosophy. Why should the Catholic Church favor Scholasticism rather than any other system? To this question again, the principle of the unity of truth will furnish a satisfactory answer.

As will be seen in one of the chapters of this work, Catholics admit philosophy and theology to be distinct sciences, having different objects and different principles. They have different objects in so far as philosoplyy is simply concerned with the truths accessible to the light of human reason, whereas theology is chiefly concerned with truths of a supernatural order. They have different principles, in so far as philosophy is guided by human reason, and theology by the authority of God.

Although philosophy and theology are distinct sciences, they often tread on a common ground. Many principles of faith, many truths known from revelation are also accessible to reason. The immortality of the soul and the existence of God may be discussed by the philosopher as well as by the theologian.

The principle of the unity of truth being admitted, we must also admit that, whenever philosophy and theology tread on a common ground, they must be in perfect agreement. As truth is essentially one, a conclusion of human reason cannot contradict a truth revealed by God. Whenever there is disagreement, there is error on one side. But, as the error cannot lie in the revealed truth, inismuch as the authority of revelation rests upon the infinite secience and veracity of God, it follows that,

"Mid., p. 5. 
in all cases of disagreement between a philosophical prineiple and a theologieal dogma, the philosophical principle must be rejected.

The only true system of philosophy will, therefore, be in perfeet harmony with the body of revealed truths. That sicholastic philosophy is not the only system capable of being harmonized with religions dogmas, we have already shown. This is why. after the speculative prineiples of the Middle Ages were judged inadequate to meet the requirements of modern scienee, most ('atholies embraced other systems. But these systems have not possessed the character of immutability which, in the mind of Catholies, necessarily belongs to truth. Not only this. 'The philnsophical systems which have been suceesively accepted in European speeulation have departed-or have been believed to depart, which, for the point we are now diseussing, amounts to the same-more and more from the essential principles of Christianity. At the beginning of the nincteenth century, the materialism of the encyclopedists was the only philosophy still remaining in France. It was openly professed by cabanis, Broussais, Pinel and Bichat. It had displaced Cartesianism itself, though a very limited number of ecelesiasties still adhered to that sytem. At the same time, some of the emigrants whom the ferocity of the Revolution had compelled to soek a refuge abroad, were coming in contact with new-born Kantism, which they were destined to introduce into their native land.

It seems, at first blush, that the philosophy thus growing in Germany was more in harmony with the great truths of Christianity than the impious materialism of the eighteenth century. Whether the philosophieal systems of Kant and his successors may be interpreted from a ('hristian standpoint is a question which has been frequently discusied and does not admit of an easy solution. It is woll known that the modern defenders of Hegelian philosophy in America invoke St. 'Thomas's authority in support of their primeiples." For my part, I feel inclined

"('f. Royer, The conception of Ciod, p. 49; Harrie, Hegel's Logic, p. ix. 
to admit that their claim is not altogether devoid of foundation. Although St. Thomas and Hegel present evident points of eontrast, it may be seriously questioned whether there exists between the systems they have built that abyss which neo-Scholasties are wont to point out. Whatever the truth may be, there is no doubt that Kant and Hegel have been invariably regarded by Catholies as the most dangerous opponents of the fundamental Christian principles. "More than any other philosophical system, says Jules Didiot, Kantism has been a serious menace to faith and natural virtues in Catholic countries."'20 Didiot is more severe still with regard to Hegelianism:

"If he (Hegel) has not intended to mock at his pupils, at his readers, at his predecessors in subjectivism and monism, we must admit that his mind was at times in a state of delirium. It is a shame for the nineteenth century not to have rejected such a philosophy with indignation. . . . That Protestant ministers in Germany may have endeavored to harmonize the doctrines of Hegel and Schelling, of Fichte and Kant, with the logmas and laws of Christianity, ean perhaps be conceived; but that Catholic priests, such as Hermes, Baader, Günther, may have dared imitate them, even from afar and with a certain moderation, is indeed hard to understand.",21

This influence of Hegel among German Catholies, so vividly deplored by Didiot, was indeed a fact in the first half of the nineteenth eentury. The Holy See was obliged to interfere. Hermes's doctrines were condemned in 1835 and 1836, Günther's in $185 \%$ and 1860, Frohschammer's in 1862, pantheism and all forms of rationalism by the Syllabus of 1864 .

Meanwhile, some distinguished French writers had endeavored to oppose the anti-religious tendeney of the day, and to build systems of thought in harmony with the spiritualistie doctrines of the Catholic Chureh. Joseph de Maistre, Victor de Bonald and Félicité de Lamennais sineerely sought a new method by which Christian beliefs might be saved and impiety checked.

${ }^{20}$ In Siecle, p. $3 \pi 7$.

"Ibid., p. 389. 
Unhappily, they endeavored to build a monument to faith upon the ruins of reason. The ultimate criterion of certitude they sought in a primitive revelation. But as the truth of this revelation could not rest upon our mental faculties, which had been proclamed impotent, it had no sure basis and the brave effort of the traditionalists was doomed to beeome in the end a lamentable failure. 'Traditionalism was finally eondemned by the Church, and, in 185.5, its last great representative, Bonnetty, was compelled to subseribe to four propositions opposed to the errors he had maintained.

It is in such circumstances that the Catholic Church seriously thought of returning to the old Scholastic doctrine. An honest cndeavor to seek the true philosophy in modern systems had been made for several centuries. But, from a Catholic standpoint, this endeavor had completely failed. The systems which had arisen in the course of time had been gradually abandoned and replaced by others, so that, as pointed out by cornoldi, there had been a continuous change in the speeulative world. The most reent systems, Materialism, Kantism, Hegelianism, Positivism, were opposed to the Catholie faith. The influener of these systems had led many Catholies to adrance dangerous theories. A system born of the laulable intention to protect the religrious idcals had been a decided failure. Such being the case, was it not better to return frankly to the phitosophy which had reigned for centuries in the schools, to endeasor to reconcile it with modern discoveries, to find out whether the old Sicholastir philosophy was not the true sytem which, for so long a time, had been sought in vain? Such is, in my judgment, the fundamental idea which inspired the nero-Thomists. 


\section{CHAPTER I}

\section{WHAT IS SCHOLASTIC PHILOSOPHY?}

\section{Section I.-Scholastic Philosophy}

The word $\sigma \chi 0 \lambda a \sigma \tau \iota \kappa o$ s was already in use among the Greeks to denote a man devoted to study. Ueberweg notes it in a letter of Theophrastus to Phanias. ${ }^{1}$ Petronius seems to have introduced it among the Romans. Under Quintilian it meant a rhetor or professor of eloquence, and we read in St. Jerome that it was granted as a title of distinction to Serapio for his unusual talent. At the opening of the Mediæval schools, the term was soon restricted to a purely didactic meaning. The scholasticus became the instructor, and the system of thought expounded in the cathedra, the Scholastic philosophy.

A distinguished French scholar, Barthélemy Hauréau, based upon this etymology a definition of Scholastic philosophy which has been generally accepted; and, on the whole, is the best we now possess: Scholastic philosophy is the philosophy professed in the schools of the Middle Ages, from the establishment of these schools to the day in which the outside philosophy, the spirit of novelty disengaged from the bonds of tradition, came to dispute with it, and withdraw from its control the minds of men. "Ia philosophie scolastique est la philosophie professée dans les écoles du moyen âge depuis l'établissement jusqu'au déclin de ces écoles, e'est-ì-dire jusqu'au jour où la philosophie du dehors, l'esprit nouveau, l'esprit moderne, se dégageant des liens de la tradition, viendront lui disputer et lui ravir la conduite des intelligences."2

'Leberweg, History of Philosophy, Vol. 1, p. 356.

"Haurau. Histoire de la philosophie scolastique, tome 1, p. 36. 
Before we proced to examine the difficulties to which this definition gives rise, it will not be amiss to make a few observations, in order to dispel all possible misunderstandings.

First of all, it seems that the etymological considerations which lead us to identify Scholasticism with Mediaval thought, ought to make us step beyond the limits of the Middle Ages, and extend our definition to modern schools as well. If it is the meaning of the words that guides us, there is no reason why the philosophy taught from the eathedra of Koenigsberg by the author of the Critique of Pure Reason should be any less scholastic than the systems of Duns Scotus or Thomas Aquinas. And, indeed, some writers, following this conception, speak of an Hegelian, a Cousinian, a Schopenhauerian Scholasticism. The ridiculous outcome of this view is obvious to every eye. It transforms into Scholastics all our university teachers. It makes Scholastic philosophy co-extensive, not only with the doctrines of Kant, Hegel, Cousin and schopenhauer, but with all modern idealistie sistems; nay, with the whole field of philosophical thought. What system has not been expounded from a profesor's chair? What philosopher has not seen his doctrines espoused in some center of learning? And we would thus be compelled to enlarge without limit the field of Scholasticism, to open its gate, not only to Hegel or to William James, but also, and with equal right, to Descartes and to Burkeley.

And yet, were ot ymology our sole guide, we should accept this view, strange though it appear. But the original significance of a word does not suftice to give us the key to its actual meaning. Aceording to John Lache, men seem to have been guided ly wit rather than by judgment in the formation of names; and a grealt discrepance has thus often come to exist between the connotation of a term and its atymology. 'The (irock word

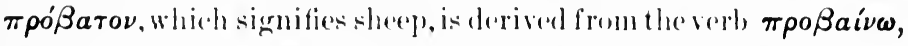
to walk forward. Still, no one would think of applying the word sheep to all heings walking forward, to include under that name, not only all our domestic animals, all denizens of the 
water and the air, save crabs and crawfishes, but our own selves.

Scholastic philosophy was originally the philosophy of the schools; and, as the name was given during the Middle Ages, it was applied to all Mediæval schools. When, at the beginning of the modern era, thought was suddenly engaged in another direction, and controlled by men who did not expound their principles from a professor's chair, a new philosophy arose, which was not scholastie, and which, after having controlled the minds of the new generation, took possession of the schools themselves, and dethroned the old philosophy, which, for centuries past, had exercised an undisputed sovereignty upon the intelligences. The philosophy of the schools thus ceased to be Scholastic, and the term acquired a definite meaning, and was henceforward exclusively applied to denote Mediæval speculation.

Scholastic philosophy, thus confined to a definite time, must also be limited with regard to space. It would be absurd to extend it to all the systems which arose in any point of our globe between the sixth and the fifteenth century, to make it embrace, not only the philosophical systems of the Arabs and the Jews, but also those of the Hindoos and of the Chinese. It must be limited to the speculation of the western world, which, in spite of numerous internal divergences, of many distinct and definite eurrents, formed a single whole, of which Paris was the center, which soon found in Aristotle an inspirer and a prophet, and in the dogmas of the Church a cynosure to direct the human mind in the perilous and unexplored regions it had so resolutely entered.

Our definition may be objected to upon the ground that it leaves us in total ignorance as to the import of the system we define. It does not throw any light upon its essential character, and may even be regarded as simply tautological, as equivalent to the statement that the Mediæval philosophy is the philosophy of the Middle Ages. We readily admit that, in defining Scholastic philosophy as the philosophy of the Middle Ages, we 
do not pretend to give what logicians would call an essential definition. But, is it possible to give an essential definition of a system of thought? Can we enclose within the narrow eompass of a definition the essential characteristics of a philosophy? It is related that Hegel, having been asked to give a brief exposition of his syitem, answered that it was not a thing that could be said in a few words. An essential definition of a philosophy is bound to be incomplete, and, in so far, erroneous. Mr. Maurice de Wulf who, in his remarkable work on neo-sicholasticism. has objected to Hauréalus definition on alecount of it: failure to give an insight into the Scholastic doctrine, has not been able to give the essential definition which the first chapters of his book had led us to expert. In point of fact, he has given no definition at all. He has exposed, in 64 octaro pages, what he considers the resential characteristies of scholastio philosophy, has summed up his exposition in a description which contains no less than ? 4 ? words, telling us that such a definition is still incomplete, that it contains only a few of the characters of Sidolastie philosophy, and that an integral definition should (omprise them all."

An attempt all a more aceeptable esential definition hals been made quite rexently by Mr. Elie Blane. He has defined sicholastic philosophy as a spirit, a method and a sestem:

"Il peut done semblere que lat philosophie secolastigure est

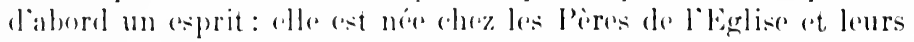
suceresemes du juste souci dareorder la raison et la foi. Elle ast ensulte une méthode rigonrense, empruntée surtout à Aristote, telle qu’il la fallait pour réaliser cet accord. Enfin elle aboutit à un sreteme toujours perfertible, dont les bases so trouvent surtout dans l'orure de saint 'Thomas."

Concerning this definition. I shall make the following romark: :

s('f. He Wulf, Introluction a la philosophio neo-secolastipue, pp. 191 192.

- Blance, Dictionnaire de philosophie ancienne. moderne et eontem. poraine, art. Scolastique. 
If, for the sake of brevity, we limit ourselves to saying that Scholastic philosophy is a spirit, a method and a system, our definition is not essential, because it leaves us in a complete ignorance as to what that spirit, that method and that system are; and is also worthless, because it can be applied to all philosophies, inasmuch as they all possess a spirit, follow a method, and constitute a definite system. It is true that Mr. Blanc explains what the spirit, the method and the system are. But the method is an extrinsic and unessential character. The spirit, consisting in a just endeavor to harmonize reason and faith, is extrinsic also. It simply refers to the relation Scholastic philosophy bears to another science, and ignores the fundamental principles of Scholasticism as a philosophy. Finally, the description of the Scholastic system as a perfectible system, whose bases are found chiefly in St. Thomas, equally fails to give us an insight into the contents of Scholastic philosophy. It does not tell us what the system is, what distinguishes it from modern thought, what constitutes it as a philosophy. Mr. Blanc's definition is no essential definition at all.

Moreover, does Mediæval philosophy possess any distinctive character, any idiosyncrasy which sets it apart from ancient as well as from modern thought? We fully realize that we here approach a difficult question, which has been already studied from different points of view, and not yet been satisfactorily answered.

Some writers have thought they could solve the difficulty by simply saying that Scholastic philosophy is no philosoply at all. 'This view was professed by the French encyclopedists of the eighteenth century, who no doubt had powerful personal motives of dislike for Mediæval speculation. They pitied all who lose their time in the study of such vain subtleties, and Diderot went so far as to say of Duns Scotus that a man who would know all that he has written would know nothing.

This kind of shallow contempt soon spread over all Europe. It became a point of fashion to deride the cloisters and the 
monks. The ass gloried in the kick he could give to the dying lion. In the second half of the eighteenth century, Briicker spoke of the introduction of Aristotle's philosophy into Europe as the signal of the most complete intellectual degeneration. More recently, Taine has given the epoch of the great masters of the thirteenth century as an age of stupidity: "Three centuries at the bottom of this black pit did not add a single idea to the human mind."'s Mr. Penjon has described the period which elapsed between the edict of Justinian (529) and the Renaissance as a sort of entracte during which there was no philosophy." Hegel himself, whose system presents so striking a resemblance with those of the Scholastics that one might be tempted to believe he has borrowed directly from them, does not hesitate to profess the same contempt. Speaking of Scholastic philosophy, he says: "It is not interesting by reason of its matter, for we cannot remain at the consideration of this; it is not a philosophy."

After modern erudition has had the courage to go back to the much-despised cra, and to remove the dense veil of ignorance which covered the works of its thinkers; after such men as Cousin, Haureau and Pieavet have displayed to the world the treasures of philosophical learning which lay concealed in those dusty folios, the superficial disdain of the preceding generation has disappeared, covered with shame. Men have repudiated the idea of a Medieval entracte, and have understood that the "dark ages" are not dark in themselves, but are dark simply for us on account of our ignorance.

There being thus nowadays no possibility of abiding by what the Germans have called: der syrung über das Mittelalter, and Scholastic philosophy being evidently something, the necessity of determining precisely what it is imposes itself upon us. And here the difficulty lies.

-Taine, Histoire de la littrature anglaise, t. I, pp. 223-22.5.

- Penjon, Prexis d'histoire de la philosophie, pp. 165. Cf. De Wulf, op. cit., pp. $11 \mathrm{fr}$.

'Hegel, Inectures on the History of Philosoplsy, Vol. 3, p. 39. 
It is unnecessary to say that Mediæval philosophy is not a single system. Embracing, as it does, several centuries of incredible intellectual activity, it must needs present that variety of opinions which is the invariable concomitant of all human speculation. A rapid glance at the whole field of Mediæval thought will not be out of place here, and will furnish us with an insight into the essential characteristics of Scholastic philosophy. We shall first examine the problem which has often been regarded as comprising within its limits the whole drift of Scholastic discussions: the problem of universals. Mr. de Wulf has recently blamed Hauréau for regarding it as the sole Scholastic problem. And indeed we agree with the distinguished professor of Louvain in admitting that the Mediæval thinkers did not confine their investigations to a single particular question, but embraced the whole field of philosophy. The problem of universals should not, however, be undervalued, as it contains in germ, not only the Medieval systems of thought, but likewise the answers which, in modern times, have been given to all great problems of philosophy.

If we start from nominalistic principles, if we atmit with Roscelin that the miversal is a mere name, a mere flatus rocis. and that nothing but the individual is real, the outcome of our philosophy will be materialism and phenomenalism. We will at first admit with John Stuart Mill that " a class, a universal, a genus or a species is neither more nor less than the individual substances themselves which are placed in the class; and that there is nothing real in the matter except those objects, a common name given to them, and common attributes indicated by the name." We shall next be bound to extend our theory to the relation of the whole and its parts; and-inasmuch as the whole bears to the parts the relation of a universal to a particular-we shall have to maintain that the parts alone possess reality and are themselves wholes. When Abelard, in his letter to the bishop of Paris, accused Roscelin of implicitly holding

8.J. S. Mili, System of Jogic, Bk. 2, chap. 2, sect. 2. 


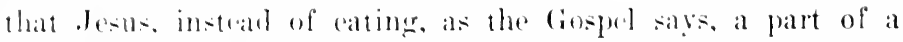
fish, ate a palt of a word, he was moloubtedly wrong. Roscelins assertion that the mniversal wats a mere word did not bind him to atmit that the fish was a mere worl. But it compelled him to profess that the fish as such had no reality that it was mothing but a complex of ultimate beings, or molecules: and that . Irens ate a tertain mumber of those molecules, which could he alleal farts of a fish only in virtue of our mental propensity to hild those miversals which are absolutely devolel of reality.

Xominalism thus leants us to materialism. It is radieally efpusend to the belief that the universe is a whole, and eamnot admit any other absolute than the molecules, the atoms. the ultimate divisions of matter, he whatever name we may ehoose to (all them.

Ind if from the objective, we pass to the subjective field, we shall see that nominalism is likewise the ancestor of empiriceism and phenomenalism. In the realm of mind, ats well as in the realm of matter, the individual will be the ultimate reality.

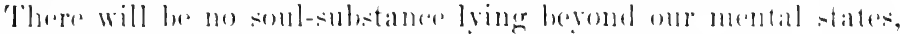

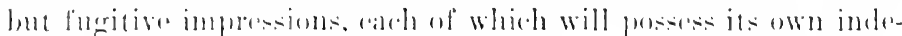
pembent axistenee. Experienees of memory themseldes will have no valielit! alpart from the present instant. and we shall

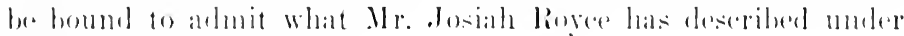

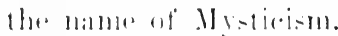

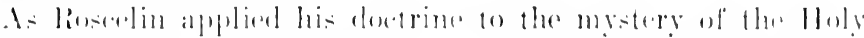

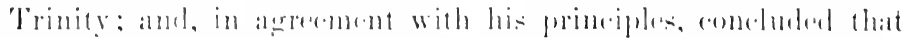
the omenes of the then divime fursons is not real: that the

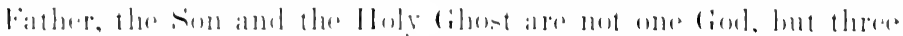

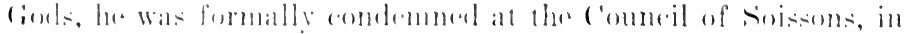

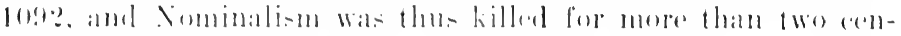

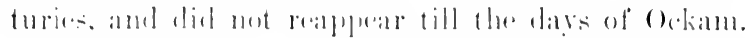

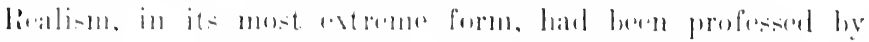

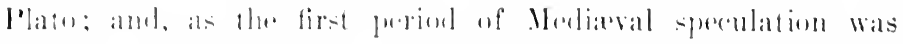

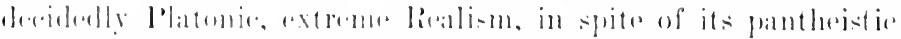

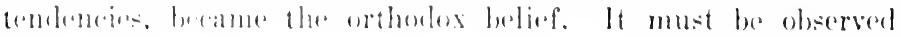


here that Mediæval realism has nothing in common with what we call realism to-day. It is the doctrine that the universal is not merely a mental construction, but possesses an objective reality; is, in point of fact, the only reality. Plato, as is well known, had taught that the real world is the world of ideas, and that the phenomenal world, our own world, possesses reality only in so far as it participates in the truth of the ideal world. This view, if logically followed out, will lead us to the conclusion that reality is of a mental nature. We shall be bound to admit with Hegel that "What is reasonable is actual, and what is actual is reasonable." We shall be incapable of avoiding monism in its most extreme form. If the universal possesses an objective reality, then being is real; and, as the universal term being can be applied to all things whatsoever, we shall have to admit that a being exists which contains all reality within itself. It is to realism therefore that most of the pantheistic systems of the Middle Ages must be traced back.

Prior to the formulation of the problem of universals, Scotus Erigena had already maintained that God is more than a creator, that he is in all things as their sole substance: "Cum ergo audimus Deum omnia facere, nihil aliud debemus intelligere quam Deum in omnibus esse, hoc est, essentiam omnium subsistere. Ipse enim solus per se vere est, et omne quod vere in his quæ sunt dicitur esse ipse solus est."

In spite of the incongruity of this view with the teaching of the Church-an incongruity which eventually led to the condemnation of Erigena's work in 1225, Pantheism again developed under the shadow of the traditional realistic doctrine, the antiqua doctrina, as Abelard had called it, displayed itself more or less timidly, according to the propitiousness of the times and the boldness of its supporters, and reached a definite form and expression in the teachings of the great Pantheistic school, which flourished at the end of the twelfth century, and counted

\footnotetext{
- Scotus Erigena, De Divisione Natura, cap. 72.
} 
as dist inguished members as Bernard of 'Tours, Amaury of Bene and I)avid of I)inant.

C'losely connected with Platonic realism are also the Mediaval mystics. Mystieism, or the doctrine that the real is the immediately felt, is, as we have seen, the logieal outcome of nominalism. It is interesting to notice that Medixval mysticism was reached by the opposite way. If we start from the assumption that the universal alone is real, we will be led to the conclusion that (iod alone possesses reality, and that everything else is mere worthless appearance. In what will man's perfection and final end then consist? Simply in the immediate union with the One, the Being, in whom all reality is centered: in a supreme contempt for all terrestrial things; in the rejection of all profane learning, of philosophy itself. And we have thus, in a nutshell, the line of reasoning followed by Mediæval mystics.

It was out of the teaching of William of Champeaux at the abbey of St. Victor that the mystic movement grew. Strengthened by the condemnation of Abelard (1121), openly protected by St. Bernarl, Mysticism found remarkable adherents in the whole Victorine school. Human reason was mercilessly condemned, dialectic was characterized as the devil's art, and Abelard, Peter Lombardus, (iilbert de la Porrée and Peter of Poitiers were denounced as "the four labyrinths of France,"10 because "they had treated with scholastic levity of the inefrable 'Trinity and the Incarnation."

Pantheistic doctrines having been repeatedly anathematized by the Church-as in the Council of Paris, in 1210, in which the teachings of David and Amaury were condemned and their works proscribed-and Aristotle having supplanted Plato as the inspirer and the guide of Medieval thinking, there appeared a modified form of realism, which had been already foreshadowed by st. Anselm, and probably also by Abelard, and which has remained since then the official Scholastic doctrine. Albert of

${ }^{10}$ In Walter of st. Victor's In Quatuor Labyrinthos Francine. Cf. Turner, History of Philosophy, pp. 302 fr. 
Bollstadt, usually known as Albert the Great, must be credited with its first satisfactory formulation. He distinguished three kinds of universals: First, the universale ante rem, existing in the mind of God; second, the universale in re, existing in the external onject; third, the unirersale post rem, existing in the known subject.

This new form of realism, which escapes the extravalyant issues of nominalism and extreme realism, has been too often ignored by modern writers, who have represented Scholasties as adhering $e n$ masse to the tenets of Plato and William of Champeaux. The new theory denies the existence of the universal as such outside the mind; but it admits in the olject a potential miversal, which may be regarded as the foundation, fundumentum in re, of the universal conecpt of the mind. There does not exist, as Plato maintained, an ideal man which contains the reality shared in a greater or less degree by all individual men; there exist only Peter, James and John; but there is in Peter, as well as in John and James, a peculiar nature, an eseence by which they are individuals of their own-not of another-species. The universal ceases to be a word devoid of meaning: it designates the vory essence of the thing itself.

The ideal world of Plato did not, howerer, completely vamish. It appeared in a new form which it had already assumed at the beginning of the Christian era. The world of ideas became the I)ivine Mind; and the essences of all things were regalded as preexisting in the asence of ciod, as reflecting more or less exactly the divine perfections. God's essence was thus described as the causa exemplaris, the infinite prototype of all reality. This is the meaning of Albert's unirersale ante rem.

Besides moderate realism, there arose between Platonic realism and nominalism another intermediate theory, known as conreptualism. The conceptualists were at one with the nominalists in denying all objective reality to the miversal; but, whereas the nominalists saw nothing in the universal but a meaningless name, the conceptualists recognized its validity as a concept. 
They atmitted that the universal is real and has a meaning, but only in the mint. Shelard has been regarded for a long time as the promoter of this view. The works of Rémusalt and (om-in would rathere lead us to regard him as a moderate realist. It all exents, conceptualism presents a striking historical interes on alcentut of its resemblance with the Kantian philosophy. It discrelates the mental aneepts from the ontside reality. It show: that the sinthetieal unity of apperention is the product of the mental watereries, and does not agrese with the thing-initsilf, which remains unknown and unknowable.

The prohlem of universals has thus led us thromgle all .llodiaeval sytems of thought, and might likewise lead us through the whole field of molern speculation. There are, however. in the Mildle Iges, als well as in modern philosopher some puestions which do not present so (dose a conneetion with the nominali-tie and realistie principles. Prominent amoner them is the dispute at to the superiority of the intellect or of the will. Thomals Aquinas was an intellectualist: louns siontus wals al

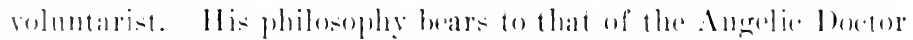
the retation that kant serstem hears to the ststem of llewel.

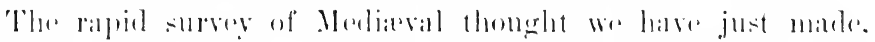
hewerere incomplete it may be, is more than sulterent to prove

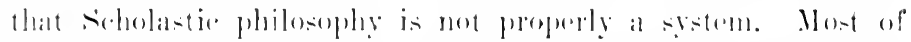

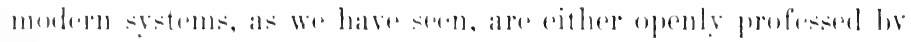

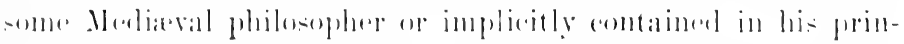

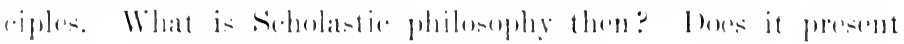
any chatratede by which it maly be distinguished from modern

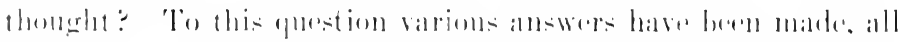
containing a certain anmont of truth, most of them heinge newertheles incomplete.

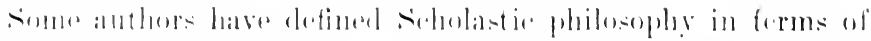

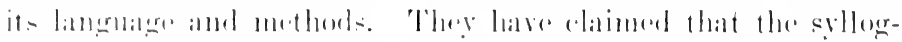

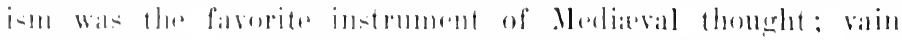

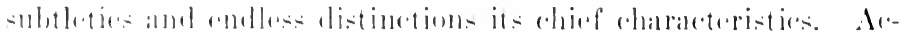

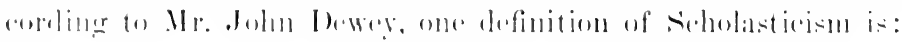


" any mode of thought characterized by excessive refinement and subtlety; the making of formal distinctions without end and without special point."11

These views are true to a certain extent. Syllogism was regarded by Mediæval philosophers, and is still regarded by some of their contemporary followers, as the most efficient form of argumentation. The syllogistic form, however, is simply a garb with which the schoolmen chose to clothe their ideas, and which they might have discarded without any essential change in their philosophy. It is a garb which is not peculiar to them alone. Besides the fact that all modern systems of philosophy could be presented in the syllogistic form without becoming scholastic, it must be borne in mind that Leibniz not only praised the syllogism, but used it in his discussions; that Spinoza expounded his philosophy in a form surpassing in strictly syllogistic, mathematical character, all that had been written during the Middle Ages. As for vain subtlety, it is certainly a most common blemish in the works of the schoolmen, a real defect, which often mars their most beautiful pages. But the student of post-Kantian idealism, who has been compelled to go over the works of Fichte, Hegel and Bradley, is little tempted to regard vain subtlety as a character peculiar to Scholasticism. He who has tried to clear the Fichtean statement that

"the reciprocal activity and passivity determines the independent activity and the independent activity determines the reciprocal activity and passivity";

its immediate consequence, namely that

"the independent activities of the Ego and Non-Ego do not reciprocally determine each other directly, but only indirectly, through their reciprocally determined activity and passivity";

and that

"In Baldwin's Dict. of Philosophy and Psychology; art. Scholasticism. Another definition of Mr. Dewey's will be discussed in this chapter. 
"the law of reciprocal determination is ralid only in so far as related to the reciprocal activity and passivity and independent activity; but is not valid as related to the independent activity alone ";

who has followed the author in the intricate applications of his principles under the conceptions of causality and substantiality; who has lost himself in that baffling labyrinth of distinetions and sub-distinctions which cover more than sixty pages of the Wissenschaftslehre; who has finally got the conviction that this eccentrie and repulsive show of analysis amounts to little more than nothing, can hardly accuse the Scholasties of monopolizing subtlety. Applying to Fichte a word which Diderot said of I)uns Seotus, he will assert with no more hesitation and with more justice than the French encyclopedist, that he who would know the whole Wissenschaftslehre would know nothing.

Another theory, more widely accepted, has defined Scholastic philosophy by its relation to theology. A formula, current during the Hiddle Ages, and regarding philosoply as ancilla theologire, has been produced; and Scholastic philosophy has been either identified with theology or characterized by its profesied agreement with the dogmas of the ('hurch.

The complete-identification-theory has been openly professed by IIegel. "The Scholastic philosophy, says he, is thus really theology, and this thoology is nothing but philosophy."12 'The same view has been adopted, in a slightly modified form, by Victor Cousin in his II istoire générale de la philosophie, and the fact that it has been recently maintained by men professing so diverent philosophieal beliefs as Alfred Weber in Germany, George 'Tyrrell in England, and John Dewey in this country, shows that it is far from being as yet completely dead:

"The ('hurch," says Weber, " is the predominant power of the Midlle Ages. Outside of the ('hurch, there an be no salvation and no science. 'The dogmas formulated by her represent the truth. From the mediaval point of view, to philosophize means

"Hegel, Lectures on the History of Philosophy, Vol. 3, p. 39. 
to explain the dogma, to deduce its consequences and to demonstrate its truth. Hence philosophy is identical with positive theology; when it fails to be that, it becomes heretical." "1:3

"By Scholasticism," says 'Tyrrell, "we mulerstand the application of Aristotle to theology, or the expression of the facts and realities of revelation in the mind-language of the peripatetics." 14

Finally, in Baldwin's Dictionary of Philosophy and Psychology, Mr. Dewey defines Scholasticism as

"the period of Medieval thought in which philosophy was pursued under the domination of theology, having for its am the exposition of christian dogna in its relation to reason."

In order to understand what amount of truth this theory contains, it is necessary to examine briefly the exact meaning given to the word plilosophy in ancient times, and the way in which the particular sciences have appeared and have been assigned a definite field.

Philosophy busied itself at first with the whole extent of human knowledge. In ancient Greece, Thales, Anaximander and Anaximenes were primarily scientists. Shmming the mythological explanations of the universe given in previous: time, they directed their efforts towards a cosmical theory more in harmony with the facts of experience. It is by an observation of the phenomena of nature-as Aristotle points out-that 'Thales was led to the assumption that all things are made out of water. Anaximenes explained the generation of fire, winds, rlouds, water and earth as due to a condensation of the first ground of all things, air. Anaximander formulated a theory of ecolution which bears a striking similarity to the conceptions of our contemporary naturalists. Aristotle himself dirl not regard any branch of human knowledge as lying beyourl his jurisliction. Ilis philosophy covers not only logie, metaphysies,

${ }^{13}$ Wober, History of Philosophy, New York, 1904, pp. 201-202.

"Tyroll. The Fath of the Millions, lst Siries. p. 22.t.

15 Baldwin's Diet. of Philosophy and Psychology, art. Scholastioism. 


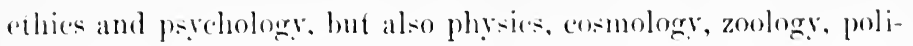
tic: and rhetoric.

When, in the course of human history, the field of knowledge was gradually extended: when it heame impossible for a single man to apply himself to all hranches of learning. particular seiences gradually acoguired a technique, and thms became independent. This movement towards specifieation was, howerer. very slow. Even in molern times, Bacon has held that the ohjects of philosophy are God, man and nature, and has included within its seope logie, physies and astronomy, anthropologr. ethers and polities; and Herbert sipencer has defined philosophy as a completely unified knowledge, and has published a sories of worlis, of which the titles: P'rinciples of Psychology. P'rinciples of Biology. Principles of Sociology, etc.. are sufficient to show that the philosophy of their author is in keeping with his definition.

At the beginning of the Christian era, the respective boundaries of theology and philosophy were not distinctly drawn. The two serenes were even generally identified. St. Augustine had said:

" Non aliam reso philosophiam, id est sappentiar studium, et aliam religionem, rum ii guormm doctrinam non approbamus ner salcramentat nohisemm enmmunieant."

Tertullian, it is true, had regarded philosephy as the mefher of heresies, and had not feared to formulate his famous: ('redo, quia absurdum. There is, loweser, exery reason to believe that he limited hit condemnation to pagan learning for he himself did not forar to philosophize. and he grave a sistem of ontology of which an irlea may he harl from the following quotations:

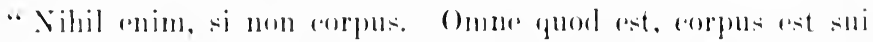
generis; nilhil est ineorporale, nisi qued non est." "17 "(uis enim

in De vera religione. cap. 5. (f. Turmer, op. cil., p. eqti.

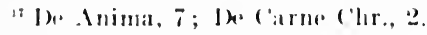


negaverit deum esse corpus, etsi deus spiritus est? spiritus enim corpus sui generis in sua effigie."18

The first period of Scholastic philosophy was a direct offspring of the patristic era and inherited its beliefs. Scotus Erigena regarded philosophy and theology as completely identical:

"Quid est alius de philosophia tractare nisi verae religionis, qua summa et principalis omnium rerum causa, Deus, et humiliter colitur, et rationabiliter investigatur, regulas exponere? Conficitur inde veram esse philosophiam veram religionem, conversimque veram religionem esse veram philosophiam."10

We have seen that Roscelin did not hesitate to apply his speculative theories to the mystery of the Blessed Trinity. For Abelard, as well as for Erigena, philosophy and theology were one and the same. It must be remarked, however, that, in Abelard's case, theology was not properly identified with, but reduced to philosophy. In other words, theology simply disappeared. Abelard's position was very much similar to that of the modern Hegelian school. Religious mysteries, if not provable by human reason, were mercilessly discarded. The words: "Nec quia Deus id dixerat creditur, sed quia hoc sic esse convincitur accipitur," 20 which so deeply offended St. Bernard's orthodoxy, may be taken as a perfect expression of Abelard's view.

The respective boundaries of philosophy and theology were soon, however, definitely fixed. The system of principles attainable by reason alone was clearly discriminated from the body of revealed truths. In Inselm's writings, although faith and reason are held in close connection, they are no longer identified. He says:

"Rectus ordo exigit ut profunda Christianae fidei credamus priusquam ea praesumamus ratione discutere. Negligentiae

sodv. Prax., 7.

Migne, Vol. exxii, col. 557.

${ }^{20}$ Introductio ad Theologiam; Migne, Vol. clxxviii, col. 1050. 
mihi esse videtur si postquam confirmati sumus in fide, non studemus quod credimus intelligere."'1

The great philosophers of the thirteenth century were at the same time theologians: and, in their most important works, they treated theological as well as philosophical questions. This fact may account for the erroncous conception which regards them as identifying the two sciences. The truth, however, is that they carefully distinguished them, and gave an account of their differences and relations which would not be surpassed by any theologian in our own day.

Philosophy differs from theology in its object and in its means: in its object, because, whereas philosophy is limited to the truths human reason can grasp, theology also embraces those which lie beyond the reach of our natural faculties; in its means, in so far as the instrument of philosophical researches is human reason, whereas theology is guided by the light of divine revelation.

These principles were recognized by all great masters of Mediaval thought, and have been so clearly expounded by St. Thomas in the first chapters of his Summa Theologica, that it is surprising they have been so often overlooked. In the very words by which the Summa opens, the respective boundaries of philosophy and theology are distinctly fixed. St. Thomas proposes the following objection:

"Videtur quod non sit necessarium prater philosophicas disciplinas aliam doctrinam haberi. Ad ea enim quae supra raltionem sunt, homo non debet conari, secundum illud Ecclesiast. 3: Altiora te ne quasieris. Sed a qua rationi subduntur sufficienter traduntur in philosophicis disciplinis: superfluum igitur videtur prater philosophicas disciplinas aliam doctrinam haberi."

To which he grives the following answer:

"Licet ea quae sunt altiora hominis cognitione non sint ab homine per rationem inquirenda: sunt tamen a leo revelata ") ('ur Denu Homo? 1, 1-2. 
suscipienda per fidem. Unde et ibidem subditur: Plurima supra sensum hominum ostensa sunt tibi. Et in hujusmodi sacra doctrina consistit." 22

With a far stronger foundation, some philosophers have thought that, although Scholastics clearly distinguished philosophy from theology and granted to the former a proper field of action, it is in the peculiar relation in which they regarded those two sciences that the idiosyneratic note of their philosophy must be found. The general acceptance this view has received from adherents as well as from opponents of Scholasticism, cannot but lead us to believe that it contains a good deal of truth. It has been accepted, among others, by Zeller, Ueberweg, Carra de Vaux, Elie Blanc, Zeferino Gonzalez in Europe, and by William 'Turner in this country.

"Scholasticism," says Ueberweg, "was philosoplyy in the service of established and accepted theological doctrines, or, at least, in such subordination to them that, where philosophy and theology trod on common ground, the latter was received as the absolute norm and criterion of truth. More particularly, Scholasticism was the reproduction of ancient philosophy under the control of ecclesiastical doctrine, with an accommodation, in case of discrepancy between them, of the former to the latter."

And William Turner, in his IIstory of Philosophy, regards the effort on the part of the schoolmen to unify philosophy and theology as the most distinctive trait of the philosophy of the schools. Therein he places the difference which divides Scholasticism from modern thought:

"Modern philosophy," says he-“ post-Reformation philosophy, as it may be called-was born of the revolt of philosophy against theology, of reason against faith. It adopted at the very outset the Averroistic principle that what is true in theology may be

" Summa Theologrica, Pars 1, Q. 1, art. 1, ad. 1. Cf. also: Art. 2, 3 and 5 , in which the nature and the relations of the two sciences are accurately discussed.

${ }^{23}$ Leberwegr. History of Philosophy, Vol. 1, p. 35.5. 
false in philosophy-a prineiple diancetreally opposed to the thought which inspired sidolasticism."

One of the characteristic notes of Mediaval philosphers is no doubt their cometant andeavor to harmonize their philosophial doetrines with the revealed truthes. It would not be fair. howerer, to fail to recognize a similar endeavor in some modern thinkers. One cannot without injustice ahsolutely assert that modern philosophers have adhered en masse to the Averrhoistic principle that what is true in theology may be false in philosophy. Malehranche, De Bonald, Gratry, Berkeley himself, have professed the same theological beliefs as Thomas Aquinas, and have tried, with as much earnestness as he, to harmonize their philosophy with their religious faith. It may be elaimed that they have not suceeded so woll; but the question now is not of success, but of profesed endeavor, and, in this respect. they are not escentially inferior to the Angelic Inoctor.

On the whole, Scholastic philosophy is primarily and essentially the philosophy of the Middle Ages, and reflects the esential characters of that time. The greatest power in the wostern world, from the ninth to the fifteenth century, was doubtless the Roman Church. The Vidlle Age's were above all an age of faith. It is faith that directerl the European armies to unknown eountries. It is faith that led myriads of younder men to the choisters where separated from the world, they devoted their lives to prayer and to study. Conder the shadow of faith, they thought of the great problems of the world. Tneler the shatow of faith they formulated their syetems of philosophy. It is for this reasem that the dogmas of the church were for them : grulde: that freedom of thomght was assigned certain limits it comld not overstep. For this reason also the harmony between

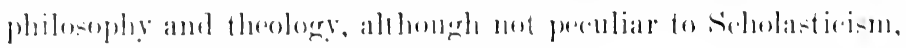
is rertaninly its mest distinctive trate.

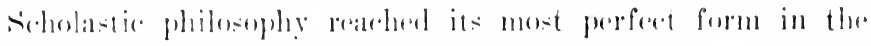

"Tormer, Hintory of Philosiphy. Ip. Hit 
thirteenth century; and, in the hands of Thomas Aquinas, became a definite system which might be deseribed as Scholastic more properly than all previous attempts. It is to this system that neo-Scholasticism universally adheres.

\section{Section 2.-Neo-Scholastic Philosopily}

The word neo-Scholastic has been opposed on many grounds.

Some men, to whom Scholastic philosophy appears as a bugbear, have been unable to reconcile themselves to the idea that such a philosophy might be revived. Behind the peaceful professor, who discusses the theory of Matter and Form, they have seen the papal power restored, the Church of Rome dethroning sovereigns and imposing her will upon nations, funeral piles erected anew, heterodox thinkers burned at the stake. As we have already spoken in our Introduction, of the relation of Scholastic philosophy to the dogmas of the Church and of the political influence of the Thomistic revival, this form of opposition to neo-Scholasticism shall not detain us any longer.

Other writers, believing that Scholastic philosophy is essentially a thing of the past, have asserted that the word neoScholasticism itself involves a contradiction. They have derided the idea of covering old theories with a new garb, of giving a modern form to antiquated doctrines. Their objection to the Thomistic revival would be perfeetly well grounded, if the historical evolution of the world were such as many writers on philosophy seem to profess. But a critical study of the various systems of thought which have appeared on our planet during the course of centuries will most likely render us distrustful in this respect. As pointed out by Mr. Woodbridge, "Aristotle reads so much like a modern that we ean conceive his writing after Hegel with no great change in his system." ${ }^{25}$ NeoScholastics believe that, amid some antiquated doctrines which must be discarded, Mediaval philosophy contains perennial ele-

${ }^{25}$ F. J. E. Woodbridge, The Problem of Metaphysics, Philos. Rev, 1903, 1. 368 . 
ments of truth: that the fundamental principles of the Pripatotic and Themistic philosophy an be fully harmonized with modern scientific results.

Even among the smpathizers of Sicholastic thought, the word nee-sedolatic has found opponents. Some have thought that the modern defenders of the philosophy of St. Thomas should not call themselves neo-seholastics, but simply Sidolastices, als the profix neo implies some modifieations in a system which should remain intact. St. Thomas's philosophy, lave they maintained, should be aceepted in its entirety or not be accepted at all. This thesis was defended by (C. M. Sichneider in the review suint-Thomasblatter. It has been defended more recently by Father Janvier, who would adopt, not only the teachings, but the very method and style of St. Thomas:

"Les mienx inspirés," says he, "prirent l'Eneyclique de Léon XIII à la lettre et sefforcèrent d'expliquer toutes les parties de la doctrine de saint Thomas en nsiant de sa méthode et an adoptant son style.".":

As was to be expected, such views have not met with a welcome acceptance. Some parts of St. Thomas's teaching are so avidently obsolete that it would be ridiculous to revive them to-day. His doctrine of the four elements, his belief in the influence of heavenly bodies upon generation, and many similar theories, cannot bereme again the object of philosophical dis'ussion. The method and language of the Sicholasties must also be modified. If the defenders of st. 'Thomas's philosophy want to come in contact with modern thought, if they want to see their dextrines discllswed in philosophical circles, they must needs adopt modern methods and modern forms of expresion. An "plosite course of action would ostracize them from the thinking world, and thereby render their work null.

It has bern finally claimed that the new scholastic movement, being ciscentially a revisal of st. 'Thomat's philosophy, ought to

"Ianvier, Lartion intellectuelle el politique de Ifon XIII, p. 49. 
take the name of neo-Thomism. To this objection also have neo-Scholasties successfully replied. The Scholastic revival follows chiefly St. Thomas because St. Thomas has brought Scholastic philosophy to its perfection. He has built a conerete system of thought which surpasses in coherence and grandeur all other Medixval systems. The adherence to St. Thomas is, however, neither servile nor exclusive. The tenets of the other Scholastics are carefully studied and given the preference whenever they prove more satisfactory to human reason. In point of fact, the words neo-Thomism and neo-Scholasticism are often regarded as convertible terms, although, strietly speaking, nenScholasticism is more proper.

The first task neo-Scholastics have assumed has naturally been an adequate and critical study of the Medixval philosophers. The works of St. Thomas have been edited anew and carefully studied. The same has been done with regard to all great Mediæval writers. Let us mention the Leonine edition of the works of Thomas Aquinas, begun at the order and under the protection of Pope Ieo XIII, and published in Rome in 1882; the edition of Duns Scotus's works, published in 1891, and comprising twenty-six volumes quarto; the edition of St. Bonaventure's works, published since 1882 by the Franciscans of Quaracchi, near Florence, and completed a few years ago; the collection: Beiträge zur Geschichte der Philosophie des Mittelalters, published in Münster, since 1891, under the direction of Mr. Baenmker; the collection: Les Philosophes du Moyen Age. begun quite recently at the University of Louvain.

These historical works are not, however, the most essential element of the neo-Scholastic program. The dearest aim of the neo-Scholastics is not to study Mediæval systems in themselves, to dissect them and present them to the eurions, as stuffed birds in a museum. It is to give them a new life, to make them meet the requirements of our day, to render them actual. In order to be successful in this task, they study the intrinsic value of the solutions proposed by the Mediæval thinkers to the great 
problems of the world, they reject those which the progress of molern science has shown to be erroneous, they discard useless questions, they aceommodate scholastic philosophy to the modcrn spirit. In so doing, they act in complete harmony with the instructions given by Le XIII in the encyclical Fterni P'atris, whose contents might be summed up in the formula universally anopted by neo-seholasties as the motto of their school: vetera noris augere.

The molifications introduced by neo-sidholasties on the philesophy of the lliddle Ages may be classified under three heads:

The first bears upon language and method. Distingruished nen-sidholistics, it is true, cling to the Lattin languagre and to the 'Thomistic method of argumentation. Some of the most important contributions to the Thomistic revival are written in Latin and do not greatly depart from st. Thomas's method. Let us mention the collection Philosophin lacensis and the works of the celebrated Spanish Jesuit Trraburm. Like st. Thomas in the summe Theologice, the authors of these works begin with an exposition of the varions opinions about each question, grive their own solution as the body of the chapter, and end with a resolution of the objections proposed by the antagonistic schools. The greater number of neo-scholasties, however, depart from this strictly Seholastie methed. They discard the syllogitic form of argumentation and writo their works in modrrn languages. The faret that the anthors who have thus morlified the siholatic method have succesded in attracting the attention of the non-sidnolastic world, whereas the learned treatires written in Latin haw been comparatively neglected, shows that modern languages and methods are nowadays more eflicarions instruments than latin for philosophical discussion. Latin is not known to-day : and, as the years go on, its importance will still dererease. This is an evil no dombt, but an evil we must acerpt. If we present to the world philosophical doetrines expresied in a languane which the world ignores, our uforts will be vain, our labor necless. 
With regard to history, neo-Scholasties have also somewhat departed from the attitude of their Medieval predecessors. Historical investigations were not neglected during the Middle Ages. They were, however, made from a point of view totally different from our own. When the old Scholastics studied the philosophical opinions of their predecessors, their aim was not so much the knowledge of the views of such or such a man as the knowledge of truth. 'They had not the idea that a man could study history for history's sake, could devote his time to an understanding of antagonistic philosophical systems, and expound opposite theories without professing any opinion of his own. The study of the tenets of the great thinkers of the past is no doubt a most powerful means of getting definite philosophical convictions. A philosophical problem can hardly be solved in a satisfactory manner, when the solutions given to the same question in previous time are ignored. The aim of the Scholastics in their study of history was thus most laudable, and, to a certain extent, must become our own aim.

Historical studies have, however, acquired in our day an importance which the Mediæval philosophers did not imagine. The doctrines of a thinker are now studied in and for themselves. We try to understand and to imbibe the very spirit of the philosophers. We are scrupulously careful not to attribute to them opinions which they did not profess.

Some of the early neo-Thomists have been loath to enter into this modern current. The late Spanish professor Orti y Lara regarded historical studies as a vain bibliomania. ${ }^{27}$ This inexcusable indifference has now wholly disappeared. Mr. de Wulf, in a recent work: Introduction à la Philosophie néo-Scolastique, in which the program of the neo-Scholastic movement is most definitely traced, strongly insists upon the importance of historical investigations. A similar insistence is found in the numerous articles, pamphlets, etc., published by Mgr. Mercier during the last twenty years. The important historical studies

${ }_{7}$ C'f. Lutoslawski, Kant in Spanien, Kantstudien, 1897, pp. $217 \mathrm{fr}$. 
published hy neo-s(holasties, and of which we have alrearly spoten, show that, on this point, they act in perfect conformity with their prineiples. Sot only have they studied the Middle Ages, but they have makr important contributions to the study of molern philosophical literature. Sutliee to mention the works of Mereier and sentroul on Kant, Ialleux's Evolutionisme en morale. which eontains a remarkable criticism on sipencer's System of Ethice. Janssens's treatise on Renouvier's meocriticism. Rickaby's recent study on Hobbes, Iocke, Ilume and Mill.

Ven-sicholasticism finally strives to keep abreast with modern scintitic progress. In so doing, it does not precisely depart from the attitude of the Mediaval philosophers. For too long a time it has been believed that the monks of the Middle Ages were unconeerned with science, and, regardless of the data of experience, built their systems a priori. This view cannot be helel to-day. It is well known that the great scholastie philosophers were enthusiastic investigators of nature: that Thomas Aquinas, Albert the Great, Roger Bacon, ete., were true seientists. The prodigrious development of seience in modern times has made it difficult for the philosopher to possess a deep seientific knowledge. Albert the Great and Roger Bacon could boast of having mastered all sciences. Not only would the same be impossible to-day, but philosophers are often apt to build their speculative systems without taking seientific data into account. And there thus result those strange philosephical theories which provoke the langhter of seientists and bring discredit upon philosophy itsolf.

Veo-selonasties hase not always escalped this danger. As wo shall se in our chapter dealing with neo-scholasticism in Italy, the arly Roman Thomists regarded seientifie investigations with the utmost eontempt. Their ignorance of science often led them to ridiculons assertions. Thus, ('ardinal Mazolla, defending in his Je lone creante. the view that the da! ss of creation are days of twonty-four hours. and somewhat perplexed 
by the fossils, which geology proves to have existed in the strata of the earth for long periods of time, does not hesitate to believe that God created them in statu perfecto, just as they are found to-day by the geologist. ${ }^{28}$ It is hardly necessary to say that such is not the position of the neo-Scholasties of the present day. The works of Farges, Urraburu, Pesch, Nys, Mercier, cte., evince a profound knowledge of all modern scientifie discoveries. The Institute of Philosophy of the University of Lourain in particular is worthy of praise in this respect. Is we shall see in one of the following chapters of this treatise, its scientifie department, as regards equipment and results, has got the start of some of the most famous European institutions.

Scholasticism is not thus a dead system studied only for its historical interest. It is a system endowed with as rivid a life as any modern current of thought, a system which must be studied in connection with modern theories, and whose answers to the great problems of philosophy can no longer be ignored. The following chapters will be devoted to an exposition and a discussion of its essential principles.

2s Mazella, De Deo Creante, pp. $156 \mathrm{fl}$. 


\section{CHAPTER II}

\section{SHOLASTE Lorite}

Whereas all other sebences nended long periods of time to areguire the definite, stetematic form they now posess. naye in many atses. fo find their right path. Hogide has hit at onde its legrtimate growelure, and has heren ahle to roaleh without delay its enmplete development. If it has not arlvanced al sinele step

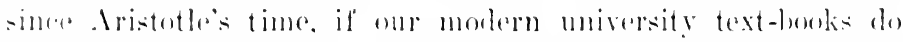
not grive us any more nor less than the dextrine of the stagrita. it is heranter logrie had hereme in his hamels a complete slsteme

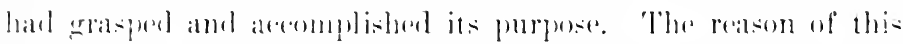

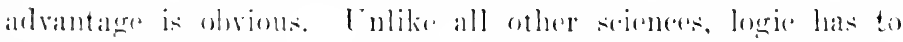
deal with the form. not with the content. of thomerht. It does not examine the immediate assmmptions from which we start; it is not concerned with the conclusions we terive from them: it deals only with the manner in which they are dorival. It is merely the art or the soremere of reasominger.

Xow, all men are endowed with simbla lateulties and reason in a similar way. The catuses of the divererenees of sperematare enclusions, of the incomplatibility of contratietory systoms, are not to lee found in the methods aceording to which these sistems arrehilt, hut in the fundamment prineiples which lie at their basis.

In morlern times. Howerer, the Aristotelian logic has heen sererely ceritioized. Eminnent anthors have condemmed its comrso of artion, deelaring its direction momatural, its mothods barren.

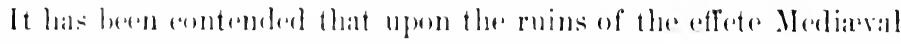
dialectie. a new sedeneer of loge had to he built. Induetion has

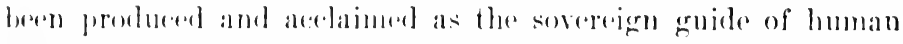

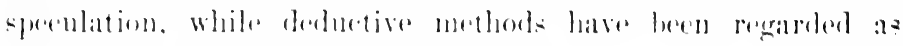

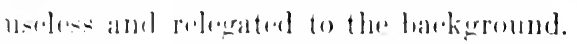


This view, due in great part to the progress of physical science, has found an able representative and defender in John Stuart Mill. The great significance of his System of Logic lies in the endeavor to reverse the process which considered the syllogistie logie as fundamental, and to subordinate the syllogism to the induction. This superiority assigned to the induction is a natural consequence of the nominalistic principles. If we start from the assumption that the individual is the only reality. and that the universal is a mere meaningless name, the syllogism loses its force and becomes a mere tantology.

The syllogism, in its most perfect form, starts from a universal, subsumes a particular under that universal, and reaches the conclusion that the attribute which belongs to the universal belongs to the particular also. Now, as the universal does not possess any validity for the nominalists, they must regard tha major premise as containing the conclusion not only formally, but materially, and henee the syllogism as devoid of all logical value.

In the example:

Man is mortal,

Socrates is a man,

therefore, Socrates is mortal,

the major premise: Man is mortal, is not. from a nominalistic point of view, a universal proposition. The term man is only a shorthand register of individual cases. It means John, Peter, Thomas, ete, and the proposition: Man is mortal, may be resolved into particular propositions, and formulated as:

John, Peter, Thomas, ete., are mortal.

Now, the subject Socrates of our conclusion either is or is not contained in the universal term man. If it is, then our reasoning is tautological, is even guilty of the fallacy caller petitio principii, inasmuch as it implieitly assumes the conclusion it pretends to prove. If, on the other hand, the term Socrates is not contained in the term man, it is by a process of induction that we extend the meaning of the term man, which 
included John, Peter and Thomas, to Socrates: and the induetion becomes the fommdation of all trutheul investigation. the basial stone of the syllogism itself.

That this depreciation of all syllogistie argumentation is openly professed hy Mill. is well known to all who have read his system of Logic:

" It must he granted," says he, "that in every syllugism, consillered as an argument to prove the conclusion, there is a petitio principii. When we say,

All men are mortal

Socrates is a man

therefore

Socrates is mortal;

it is unanswerably ured by the adversaries of the syllogistic theory, that the proposition, Socrates is mortal, is presupposed in the more general assumption, All men are mortal: that we cannot be assured of the mortality of all men, unless we were previously certain of the mortality of every individual man: that if it be still doubtful whether socrates, or any other individual you choose to name, be mortal or not, the same decree of uncertainty must hang ofer the assertion, All men are mortal: that the gencral principle, instead of being given as evidenee of the particular casc, cannot itself be taken for true without exerption, until every shadow of doubt which rould affect any ase comprised with it, is dispelled by evidence aliunde; and then what remains for the syllogism to prove? that, in short, no rasoning from generals to particulars an, as such, prove anything: since from a general principle gou camnot infer any particulars, but these which the principle itsolf assumes as foreknown."

This view, perfoctly enelusive for the adherents of nominalism, loses its value if, with the great scholastio masters, wo admit the valielity of the universal: if we regard the word man as meaning, not simply John, Proter and Thomas, but a moversal rerenere erommon to all posihle men. The error of the nominalists lies in the anfusing the denotation of a torm with it -

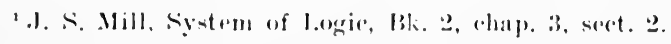


ronnotation; and, if Mill tries to clear himself from such an accusation, it is on account of an inconsistency which runs through the whole of his System of Logic, and appears as a continual puzzle to the uninitiated reader.

The conclusion of a syllogism is contained formally in the major premise, but not materially. As the universal term man denotes the essence common to all human beings, it also denotes the essence of the individual Socrates; and, if mortality is one of the characteristies of the human essence, it will undoubtedly be a characteristic of Socrates. The conclusion, Socrates is mortal, is, however, contained in the major premise implicitly only. We may be convineed of the truth of the assertion: Man is mortal, because we know that luman nature as such involves the element of mortality (the human body being an organism, and all organic beings being subject to growth, decay, and dissolution); and not lave realized that the individual Socrates is mortal also. The logical value of the syllogistic reasoning consists then in making explieitly known what was known implicitly, in enlarging indefinitely the field of our a priori knowledge. Inder its dominion lie all a priori sciences, pure mathematics as well as philosophy.

The induretive process was not unknown to the Mediaral philosophers. Without mentioning Roger Bacon, who not only insisted upon the use of observation and experience, but condemned all deductive reasoning, we find well conducted examples of induction in Thomas Aquinas, Duns Scotus and Albert the Great. A remarkable passage of the work De motibus animalium. ${ }^{2}$ in which Albert the Great maintains the thesis that the origin of all motions of animals is on the back of the head. might have been written after Mill's system of Logic without any essential change. ${ }^{3}$

These examples of induction in the modern sense were, how-

2Lib. 1, tract. 2, cap. 1, 2, 3.

' ('f. Mansion, Linduction chez Albert le Girand, Rev. Neo-Scol., 1906 , ip. $246 \mathrm{ff}$. 
ever, exceptional. 'Their amthors themselves ansidered them as of little importance: " The seience of nature, said . Mlhert the Cireat, must not simply gather facts, it must lowk for the aluses of the natural phenomenat."

This undervaluation of inductive reatsoning was due to the faret that the particoular soiences had not got aleguired a field of their own, and were rearaded as forming part of philosophy. Positive sedences, concerned with facts and laws. Wore al pot unknown.

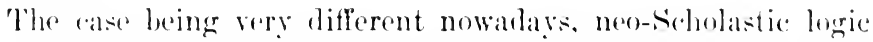
is not satisfied with a repetition of the logical doctrines of the Midlle Igres. In harmony with Leo XIIl's formula: Velern noris augere, it makes a thorough study of the inductive process.

Deductive reasoning, however, does not therely disalprear. It possesses a field of its own, in which induction has nothingr to do. Enjoying an undisputed sovereignty in the soience of nature, induction is absolutely powerless in the field of the a priuri scienees, such as mathematies; in the field of all those sciences which our mind in a certain sense creates.

- De mineralibus, lib. 2, tract. 2, cap. 1. 


\section{CHAPTER III}

\section{SCHOLASTIC METAPHYSICS}

\section{Section 1.-Existence of Metaphysics}

The word Metaphysics was unknown to Aristotle. It is probably due to Andronicus of Rhodes, a compiler of Aristotle's works, who was unable to reduce the fourteen books actually known as Metaphysies either to ethics, logic or physics. The word had therefore originally no intended meaning beyond a elassificatory purpose. Very soon, however, its connotation underwent a change and was taken to be, not what merely comes after, but what is essentially above physics. St. Thomas brings the two meanings together in the following words: "This science is called metaphysics because its study follows the study of physics, as we are naturally inclined to pass from sensible to supersensible things."1

General Metaphysics, also called Ontology, has often been defined by neo-Scholastics as: the science of Being in general, or of Being as Being. This definition has been opposed by Mgr. Mercier on the ground that the notion of being in general is analogical, and covers a multitude of things with which ontology has nothing to do. It embraces objects of totally diverse natures, such as substances and accidents. It even extends to the logical being. Now, the logical being has its proper place in logic. As for accident, it is not studied in metaphysics except in so far as it is related to substance. The proper object of metaphysics, according to Mercier, is thus real heing or substance. Metaphysics is not concerned with what Hegel alls "Pure Being," and shows to be equal to nothing.

${ }^{1}$ Thomas Aquinas, In lib. Boetii de Trinitate. q. 5, a. 1. Cf. Mercier, Ontologie. P'. .7-6. 
Its vital problem, as Mr. Woodbridge points out, is the nature or character of reality, and accident and logical being come within its field only in so far as they are regarded as real.

Scholastic metaphysies has met, in modern times, with powerful adversaries whe have tried, not only to deprive her of the sovereignty which, as queen of the sciences, she had so long exercised, but to banish her altogether from the world of thought. She who, for centuries, had seen the most powrrful geniuses prostrate at her feet, has been driven out, without merey, from the field of human speeulation. She has lingered for a long time, as an outlaw, in some obscure corner of her former realm, and to-day she reappears more resplendent than ever, and dares meet her old foes face to face.

The two great currents of thought which have rejected metaphysics as vain in its object and erroneous in its conclusions are Positivism and Kantism.

According to Auguste Comte, the attempt to grasp the essences of things is a futile endeavor. We cannot go berond actual facts and laws of facts. Identical are the views of Herbert spencer. For him, our knowledge is limited to appearances, and the reality lying behind those appearances is and must be unknown. ${ }^{3}$

Positivism thus rejects metaphysies, is even bound to reject it. I philosophy which professes not to step beyond the facts of sensible experience cannot reach the universal nature which is the object of all metaphysical speculation. It should even albandon all attempts at expresing the laws of facts, and be contented with the immediate, with the "this," which is the only thing devoid of all metaphysieal dement.

Kant, whose aim wats to combat llumes secepticism and thus to save metaphysices from utter destruction, has perhaps dealt her the most serere blows. He has tanght that our knowledge is conditioned hy our natural faculties, and that the reality

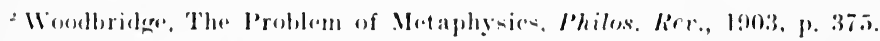

s'f. Prencer, First l'rinciples, (hap). 4. 
which we see through the forms of sensibility and the categories of understanding is necessarily distorted by these subjectivi conditions and never appears to us as it is in itself. It is phenomena that we know. The noumenon, the thing-in-itself, is alsiolutely unknowable. A science professing to deal with reality als it is becomes therefore meaningless and absurd.

Both Kantians and Positivists labor under the same misconception. All facts of experience have come to be divided into two great classes. Some are known as real, others as apparent. We have observed that a stick which looks straight in ordinary conditions looks crooked when immersed in water. As our sense of touch does not in this case corroborate the conclusions of our visual experience, we conclude that no real change has taken place in the stick itself, that it is still really straight, but appears crooked.

This division is swallowed up by all defenders of the absolute relativity of knowledge. They undo, as it were, the work of experience, and leave us at our starting-point, where we cannot escape the necessity of beginning our work over again. If reality lies altogether beyond our reach, it is as non-existent for us, and the appearances, the phenomena with which alone we have to deal, become the only possible object of research, the only reality. With them a new metaphysics must needs arise, which, upon close examination, will be found to be exactly the one we have rejected.

The positivistic and the Kantian positions are thus untenable. They are also illogical. Both positivists and Kantians reach conclusions that are metaphysical in themselves and unattainable without the help of metaphysies. They assert, for example, that all knowledge is relative and that reality is absolutely unknowable. This is a conclusion about the nature of reality itself, a conclusion which in so far is metaphysieal. And if we go on saying with Spencer that the unknowable force lying beyond our experience is the cause of our sense-impressions, or. with Kant, that the thing-in-itself is the necessary condition of 
the existence of the phenomenal world, if we know and deseribe the effects which the ahsolute reality produces, we thereby profess to know a good deal about this reality and can hardly describe it at absolutely unknowable.

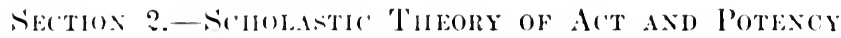

One of the most enlightened among neo-Scholastics, Mr. Althert Farges, regarals the doctrine of Act and Poteney as the foundation-stone of the peripapetic and Thomistic metaphysic:. "Ia théorie de lacte ct de la puissance. du moteur et du mobile at la rlef de voûte de tout ce gigrantesque édifice álevé à la gloire de la philosophice spiritualiste par le génie d'Aristote et de saint Thomas d'Aquin." ${ }^{4}$ This doctrine has been, however, so often derided in modern times that Mr. Farges's words will at first savor of paradox. The Scholastics have been accused of introducing into their philosophy mysterious entities, occult causes, and of moving thereby, in the most strange way as by means of invisible threads, the whole machinery of the world.

In order to remove all possible prejudices, it will be well. before proceeding to explain the theory of Act and Potency, to quote the opinion of two men who are certainly not biased in favor of Scholasticism. "The first of them is Mr. Vacherot. speaking of the peripatetic philosophy, he expreses himself thus:

"It is the sechoed of Aristotle eperecially, which is a school of serence and of positive philosophy. . . Xothing is less specelllative than his philesoplye, if the torm speculative is meant for a priori conception. . . The whole doctrine of Aristothe rests upon a formula, which is the most ahes ract and the highest expresion of experience: Poteney and Act, two words which sum "1, his thought and explain wergthing:.".

Mr. Bontrous likewiere, although a sincere Kantian, not only does full justion to Aristotle, hut soems to profor his teathing

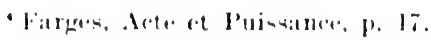

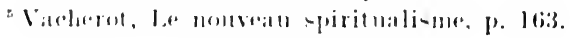


to the doctrine of Kant himself. He recognizes that Aristotle's philosophy answers particularly to the scientific preoccupations of our time, " répond particulièrement aux préoccupations scientifiques de notre époque."

The exposition of the doctrine of Act and Potency demands, as an indispensable pre-requisite, an analysis of the concept of motion.

The existence of motion or change was denied by the old Eleatic school. It is said that Aristotle, in answer to certain sophists of his time, who endeavored to revive Parmenides's and Zeno's arguments, simply began to walk. 'This answer, so trivial in appearance, was as profound and irrefutable as could be. It meant that motion is a fact of our experience, and cannot be denied, because it is there and constantly forces itself upon us. Should it even be said that all movements and changes are deceitful appearances and that reality is immutable, one is compelled to admit that those appearances are still there, are real and must be explained.

Aristotle, in his Physics, distinguishes three classes of movement: a movement purely local or of translation; a change in quality, which he calls alteration; a change in quantity, or development and reduction of mass. ${ }^{\top}$

Wovement is thus understood in a broad sense and cannot be identified with local motion. Change of place is rather an effect of motion than motion itself. The essence of motion rather consists, to use Farges's words, in a tendency, a becoming, an instrument of evolution for the material forces of nature, "une tendance, un devenir, un instrument d'évolution pour les forecs matériclles de la nature."

Now, the changes we observe in our universe do not take place at random, but according to definite laws. Whenever an object is placed in determinate conditions, it begins to act in such a

- Grande Encyclopedie, art. Aristote.

'Phys., 1V, e. 2, sect. 10.

' Farges, Acte et Puissance, Sect. V. 
way as to show that it possesses a peculiar nature, that it is a unique individual. In other words, we are bound to admit the existence of purpose in our world. The word purpose has now come to mean a conscions scheme. It has been identified with design. The old scholastics did not hesitate to use it in a broader sense. They spote of intentio nature or appetitus naturalis to derignate the uneonscious tendencies of lower beings.?

When we say that our univerese is purposive, we do not therefore mean that it is made aceording to a plan; that it is designed by a suprente being who directs everything to his ends, who, hidden behind the scenes, moves the whole mechanism. Our world may be thus designed, it is true, but this is not the question now. We only mean that the individuals of our world are controlled by their own character, that they naturally tend to a definite result. Te may thus consider in each individual two different states: the one in which it is still underdoped, determinable, has not acquired the foll perfection it naturally tends to the other in which it is already determined, perfected, has reached it: final goal. The first of these states is called potential by the scholastics, the second actual. A potential being is thus an imperfect, but perfectible being. An actual being is a being alreaty perfected. The acorn is potentially an oak.

No myterious astumption, I believe, is needed to reach these conchusions. Potentiality is not an oceult cause existing behind the arorn and aeting upon it in some unthinkable manner; it is the peculiar character whieh the acorn pessesses as an individual, and by when it is distinguished from all other individuals, the property which enables it to become an wak and nothing else. It mav be imporsible to tell beforehand the nature of the aletuality ceward which a potential lecing tents. I microsecopical examination of the acorn will not show us anything resembling an vak. Ln amalysis of the potential will not give us the actual. It is the aretual itcelf that will crince the potentialities of the being which galse it birth. The vary fact, however, that the

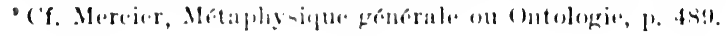


acorn, and the acorn alone, invariably becomes an oak, compels us to admit that the acorn possesses some individual propertics which a pea does not possess, that it contains potentially an oak, while the pea does not. Nothing further than this do the Scholastics maintain.

We are now in a position to understand Aristotle's famous definition of motion as "the act of the potential being as potential."

Between the purely potential state of the being which is not as yet tending towards an end, and its final condition after the end is reached, there are intermediate stages. The new-born child is potentially a Kantian philosopher, although he has not yet done anything towards an insight of the Kantian theory. Between the state of his mind then and its final condition when the three Critiques are adequately grasped, a long period of time will probably elapse. There will be the university stage, in which the young student will learn with amazement that space is in his mind, the following years of struggle against a thought strange in itself and untowardly presented, epochs of failure and discouragement, epochs of partial success.

The new-born child possesses the Kantian philosophy potentially; the full-grown philosopher who has mastered the three Critiques possesses it actually; the university student is in a state of movement.

Motion is thus an act of the potential being; an act, because the potential being which is merely potential does not yet tend towards its end, is not yet in motion; an act of the potential being, beeause if the being is already actual, has completed its coolutionary process, it is not in motion any longer. Motion is an act, but an imperfect act; an act which has not yet reached its full degree of actuality, and is now completing itself.

Section 3.- Scholastid 'Thery of Substance

'The simplest observation upon the objects of our experience, shows that they may be divided into two great classes. Some, 
as a horse, a trow, a man, we conceive as existing by themselves. Others, as walking. amnot exist hut in something else. The former are called substances by the scholatsties, the second, alceidents, qualities, attributes. Sicholastic philosophy thus defines

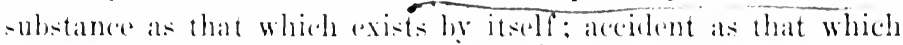
annot exist he iterlf, hut alwals exists in something else.

The etrmology of the word substance (sub-stantia) involves. it is true, a different meaning. It evokes the idea of a substratum, of sone sort of recipient in which the attributes inhere. liut, as we have clsewhere remarked, the etymology of a word does not always grive us the key to its actual meaning. In our epoch of religious liberty, a Protestant may spend his whole life without actually protesting against any religrous dogma. He still calls himself and really is a Protestant.

fo doubt the accidents, being mable to exist by themselves, exist in something else: and substanee may be thus correctly described as that which supports accidents. This is not, howwer, the primary meaning of the worl substanee, which strictly signifies that which exists hy itself.

Before we proced to a more detailed study of the concepts of substance and accident. it will be worth while to examine some of the modern theories which have rejected the term substance altogether, or have moditied its meaning so as to render it unrecognizable.

(of the aldersaries of substanere, John locke must head the list. Sot herause he is an open fore. He hrestates. foels disratisfed with his bellicose attitude. would fain come to a eom-

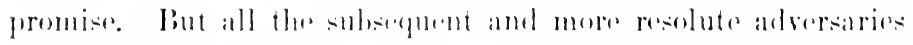
hawe been at his shool. It is his primeiples they follow; it is in his workthelp they have found their most dreadful weapons.

like many motern philesephers, John lacke regards sub-

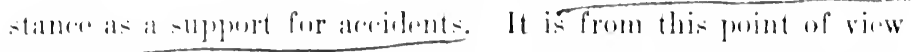
That he alms his misiles so that, to al cortain extent, he constantly mi-ne the matl: 
"They who first ran into the notion of accidents as a sort of real beings that needed something to inhere in," says he, "were forced to find out the word substance to support them. Had the poor Indian philosopher (who imagined that the earth also wanted something to bear it up), but thought of this word substance, he needed not to have been at the trouble to find an elephant to support it, and a tortoise to support the elephant: the word substance would have done it effectually.",10

He consequently asserts that we have no clear idea of sub-
stance:

"We have no such clear idea at all, and therefore signify nothing by the word substance, but only an uncertain supposition of we know not what, $i$. $e$. (of something whereof we have no particular distinct positive) idea, which we take to be the substratum, or support, of those ideas we know."11

(Let us parenthetically point out a somewhat unexpected metamorphosis. We had believed substance to be a support of accidents. We are now told it is a support of ideas. Our author seems willing to prove by all possible means the truth of his assertion that he has no clear idea of substance.)

Let us not, however, misunderstand Locke. He would by no means maintain that we are in absolute ignorance as to what substances are; he even positively asserts that we have a real knowledge of them. But he adds the restricting clause that this knowledge does not go very far:

"Herein therefore is founded the reality of our knowledge concerning substances, that all our complex ideas of them must be such, and such only, as are made up of such simple ones as have been discovered to co-exist in nature. And our ideas being thus true, though not perhaps very exact copies, are yet the subject of real (as far as we have any) knowledge of them; which (as has been already shown) will not be found to reach very far; but so far as it does, it will still be real knowledge."12

${ }^{10}$ Locke, An Essay concerning Human Understanding, Bk. 2, chap. 13 , sect. 19 .

${ }^{11}$ Ibid., I3k. 1. chap. 4, sect. 18.

${ }^{12}$ Ibid., Bk. 4, chap. 4, sect. 12 . 
Our knowledge of substanee, which hat been described as " nothing but an uncertain supposition of we know not what," is now confessed to be a real knowledge, as real as any knowlolge we maly have, and locke's opponents may doubt whether his attacks were not merely the mock-fight of a stage performer. He will presently throw his weapons away, and we will hardly br able to repress a smile on realing the following terms of surrender:

"It is of the idea alone I speak here, and not of the being of substanes. And having everywhere affirmed and built upon it, that a man is a substance, I cannot be supposed to question or doubt of the being of substance, till I ean question or doubt of my oun being." 13

David Iume is, or tries to be, more consistent than his master. Mis rejection of substance seems at first sight well grounded and unanswerable, and has deserved him the crelit of having delivered philosophy from a cumbersome and useless conception, of having done away with the soul-substance itself, as Borkeley had done with the bodily substance.

IIume's attack on ancient philosophy is a sharp attack indeed. IIe is eareful, however, before engaging in the struggle, to tell us-with a certain naïrote- that he does not understand ancient philosophy at all. "'The whole system, says he, is entirely incomprehensible." Now, it is perhaps too much to say that a system of philosophy is not understood until it is beliered; but it cannot be denied that a sistem of philosophy is not understond until belief in it seems at least posibible. Artistotle was a man whose mental shrewdness Hume certainly did not surpass, when deroted his whole life to study as carnestly as Hume did, who lived in a country not inforior as regards civilization to Ilume'; own country, who moved in a more intellectual atmosphere, who breathed a purer air. The system of philosophy Aristotle con-

${ }^{13}$ Ilide, Bk. 2, chap. 23, sect. 1, Note.

"Hume, Treatine on Hluman Nature, Bk. 1, Pt. 4. Sict. 3; Selloyligigg"s ad., p. 22:2. 
trived was undoubtedly plain in his own mind. If it appears entirely incomprehensible to Hume, it simply means that Ilume does not understand it as Aristotle did, does not, in point of fact, understand it at all.

For Hume, as for Locke, substance is primarily a kind of substratum, something unknown and invisible, which continues the same amid all variations:

"In order to reconcile which contradictions the imagination is apt to feign something unknown and invisible, which it supposes to continue the same under all these variations; and this unintelligible something it calls a substance, or original and first matter."15

But as, according to him, all qualities (such as the color, taste, figure, solidity, etc., of a melon) may be conceived as distinct and separate, they do not need any support, and substance becomes an unintelligible chimera:

" Every quality being a distinct thing from another, may be conceived to exist apart, and may exist apart. not only from every other quality, but from that unintelligible chimera of a substance."10

Hume is decidedly a most interesting man. After devoting all his energies to drive away the notion of substance from the field of philosophy, he reduces to naught, by stroke of pen, his elaborate work, and presents to his amazed reader the following statement:

"If any one should evade the difficulty by saying that the definition of a substance is something which may exist by itself; and that this definition ought to satisfy us: Should this be said, I should olserve, that this definition agrees to everything that can possibly be conceived; and never will serve to distinguish substance from accident, or the soul from its perceptions. ${ }^{17}$

"Ibid., J3k. 1, Pt. 4, Sect. 3.

${ }^{16}$ Ibid., Solby-13igge's ed., p. 222.

${ }^{17}$ Ibid., Bk. 1, Pt. 4, Sect. 5; Sellyy-lBigge's ed., p. 223. 
That sulstance is something existing by itsolf is indeed the only thing the supperters of the idea of substance maintain; and Hume, unensedeus!y, unwillingly frerhaps. heromes one of their number. There is, it is true, in his statement, an inadmissible dement of which I will speak in the sequel: but the fundamental principle it contains is in perfeet harmony with the dectrine for which the supperters of the existence of substanee contend.

I few more work before dismissing llume. Substances have gentrally been divided into bodily and mental. Berkeley is commonly supposed to have done away with bodily substances; Hume, with mental substances. This view must be qualified. Hume acknowledges that he believes in bodies - that is to say, in bodily substances-and thus seems to go one step backwards, to destroy Berkeley's elaborate work:

"We may well ask," says he, "What "ause's induce us to believe in the existence of body" but it is vain to ask, Whether there be body or not? 'That is a point which we must take for granted in all our reasonings." 18

As regards mind, it is true that he resolves it into a heap or collection of perceptions:

". Minel." he says, " is nething but a heap or collection of different perceptions, united together by certain relations, and suppoisel, thromoh falsely, to be endowed with a perfect simplieity and identity." 19

Which means that there are preceptions, ant there is no mind.

But when, in reading the Treratios on II uman Vature, we find such expresions ats these:

"It will always be impessible to deciele with cortainty, whether they (the imprestens) arise immediately from the

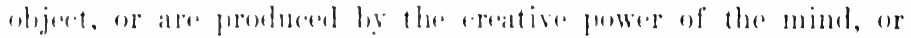
ane derivent from the anthor of our heing.".". "I pon the

"Ilial., lik. 1, J't. 4, seret. 2.

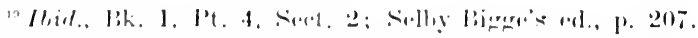

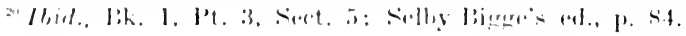


whole, necessity is something that exists in the mind, not in objects." ${ }^{21}$. . " Impressions are naturally the most vivid perceptions of the mind." 22 . . "The mind falls so easily from the one perception to the other, that it scarce pereeives the change." ${ }^{23}$... "We may pronounce any quality of the mind virtuous which causes love or pride." 24 . . "When I perceive the eauses of any emotion, my mind is conveyed to the effects, and is actuated with a like emotion." . . " It being almost impossible for the mind to change its character in any considerable article, or cure itself of a passionate or splenetic temper, when they are natural to it," 26

we feel strangely perplexed as to what Hume's meaning really is. It sounds odd to speak of states of mind if there is no mind. The words I, our, us, themselves become meaningless if perceptions alone are and we are not.

These considerations may give us some suspicion as to the real worth of Hume's famous rejection of substance. 'They will not perhaps induce us to proclaim with Rickaby that " the acceptance of Hume's doctrine by so many of the philosophers in England is a disgrace to the sound sense of the nation " $;^{27}$ but they will compel us to study the conception of substance once more, to examine whether the philosophy which advocate: its legitimacy is not, after all, the philosophy of truth.

It would be useless to pass a review of the contemporary philosophers who reject substance from their system. They do little more than adopting Hume's principles and repeating his arguments. Those among our university professors who have not yet come back to Aristotle's point of view simply tell us in their own words what Hume said long ago. The Treatise on Human Nature is their profession of faith.

"I Ilid., Selby-Bigge's ed., p. 165.

$=2$ Ibid., p. 208.

${ }^{23}$ Ibid., p. 208.

"Ilid., p. 575.

${ }^{25}$ Ibid., p. 576.

"s Ibid., p. 608 .

${ }^{27}$ Rickaby, General Metaphysics, p. 238. 
There is one contemporary writer, however, who deserves to be singled out from the throng, and whose philosophy will detain us for a moment. I speak of John Stuart Mill.

Mill aceepts the common division of substances into bodies and minds. Ile defines a body as " the external eause to which we ascribe our sensition ";2- a mind as " the unknown reciphent, or pereipient of them." At the first hush, this sems very Gear: but, unlike many other writers, Mill posiseses the peculiarity of appearing clear at a first reading and less elear when we reall him again : and, strange to say, the more we read him, the obscurer he becomes. It one place, he tells us that,

"as we know not, and cannot know anything of bodies but the sensations which they "xcite in us or in others, these sensations must be all that we ean at bottom mean by their attributes, and the distinction which we verbally make between the properties of things and the sensations we receive from them must originate in the convenience of discourse rather than in the nature of what is denoted by the terms ", 30

at another place, that

"a sensation is to be carefully distinguished from the object which causes the sensation; our sensation of white from a white object; nor is it less to be distingruished from the attribute whiteness, which we ascribe to the object in consequence of it: exeiting the sensation." 31

Here, after explaining that a aluse does not as such resemble its effects, that an east wind is not like the feeling of cold, nor heat like the steam of boiling water, that matter therefore doest not neessarily resemble our sensations, he conchudes that

"it may be safoly laid down as a truth both obvious in itself, and andmitted by all whom it is at present necessary to take into comsideration, that, of the outward world, we know and can

$\therefore$ J. S. Mill, System of logic, Bk. I, chatp. 3, sect. 7 .

2llid., lik. I, chalp. 3, sect. 8.

o Ibid., Bk. I, chatp. 3, sect. 9.

"Ibid., Bk. 1, chap. 3, sert. 3. 
know alssolutely nothing, except the sensations which we experience from it " $; 32$

and a little further he criticizes Locke for admitting

" real essences, or essences of individual objects, which he supposed to be the causes of the sensible properties of those objects." 33

Mill's eonception of substance is thus far from being clear. There is, however, one point which he has perfectly grasped. He admits that substance is primarily that which exists by itself :

"An attribute," says he, "must be the attribute of something: color, for example, must be the color of something; and if this something should cease to exist, or should cease to be connected with the attribute, the existence of the attribute would be at an end. A substance, on the contrary, is self-existent: in speaking about it, we need not put of after its name. A stone is not the stone of anything; the moon is not the moon of anything, but simply the moon." 34

It is not easy to see why Mill, eriticizing this conception, finds in it lessons of English, Greek, Latin or German, rather than of mental philosophy. When we say that a color is the color of something and that the moon is not the moon of anything, we do not apparently use meaningless words. We speak about the real objects of our world, and describe them just as our experience presents them to us. As we never find in nature a color existing by itself, and we find a moon existing by itself, we feel compelled-not by the necessity of our language, but by the necessity of the kind of reality we have got-to speak of a color as a color of something, and to speak of the moon as simply the moon. It is reality which obliges us to distinguish a substance from an attribute, to ascribe to the former a character which the latter does not possess.

${ }^{32}$ Ibirl., Bk. 1, whap. 3, sect. 7.

${ }^{33}$ Ibid., Bk. 1, chap. 6. sect. 3.

"Ibid., lik. 1. chap. 3, sect. 6. 
Mill, however, tries to corroborate his views by the following argument :

"As for the self-xistence of substances, it is very true that a substance may be conceived to exist without any other substance, but so also may an attribute be conceived to exist without any other attribute: and we can no more imagine a substance without attributes than we can imagine attributes without a substance. ${ }^{-3}$ s

'This reasoning seems obvious enough; and, when expressed in the antithetical language used by Mill, may even appear convincing. A little consideration, however, shows that it lies under a groat confusion of ideas. If the clause "an attribute may exist without any other attribute" simply means that an agreeable odor may be indifferently joined to a red or to a blur color, it is undoubtedly true, but does not amount to much. If'. on the contrary, it means that an attribute may exist hy itself. without any other conjoined attribute, it must simply be denied on the gromed that it involves a contradiction, inasmuch as the being thus described would not be an attribute, but a substanee.

There is no doubt that we can no more imagine a substance without attributes than attributes without a substance. 'The attributes are the very clements of the substance, so that a sutbstance without attributes would mon a substance withont elements, or, in other worils, a thing which would be equal to nothing. But the self-existence of a substance does not and rannot mean that it exists without attributes. It means that it exists hy itself, while the attribute does not; and herein lies the resential differener betwern them.

some philospluers, while admitting the validity of the eon(rept of substance, have griven more or less inalequate definitions of it. llosartes identifies substance with extension or thought:

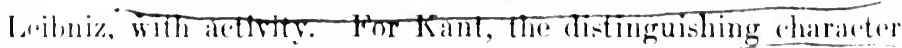
of sulstance is permanenes: "Th all changes of phenomena,

sistrid., lik. 1. rhatp. 3. sect. li. 
substance is permanent, and the quantum thereof in nature is neither increased nor diminished." 36 This seems to be also the view which Hegel tries to convey in his usual, attractive language :

"The necessary is in itself an absolute correlation of elements, i. e., the process developed (in the preceding paragraphs), in which the correlation also suspends itself to absolute identity. In its immediate form, it is the relationship of substance and accident. The absolute self-identity of this relationship is substance as such, which as necessity gives the negative to this form of inwardness, and thus invests itself with actuality, but which also gives the negative to this outward thing. In this negativity, the actual, as immediate, is only an accidental which through this bare possibility passes over into another actuality. This transition is the identity of substance, regarded as formactivity." ${ }^{3 i}$

Finally, a few authors have believed that substance is essentially a substratum, an unknowable something lying beyond the accidents, and have thus justified, to a certain extent, the confusion from which the thinkers who reject substance altogether have derived their greatest strength. Not otherwise is substance defined by the celebrated Spanish philosopher, James Balmes. He regards it as a substratum, "a thing which is no color, but lends itself to all colors; which is none of the qualities which we experience, but the subject and cause of them all ";38 a permanent substratum:

" a permanent being in which occur the changes which are presented to us in the sensible phenomena " $; 3$

an unknowable substratum:

"In vain you ask me, what is this being? Give me the intuition of the essence of corporeal things, and I will tell you; but while I know them only by their effects, that is, the impressions which they produce in me, I cannot answer you." 40

${ }^{36}$ Kant, Critique of Pure Reason, Meiklejohn's transl., p. 136.

${ }^{37}$ The Logic of Hegel, Wallace's transl., pp. 273-274.

${ }^{3 s}$ Balmes, Fundamental Philosophy; Brownson's transl., Vol. 2, p. 338.

39 Ibid., Vol. 2, p. 339.

"Ibid., Vol. 2, p. 339. 
st. 'Thomas and the Scholastics. however. rexard substance primarily as that which exists by itself ; and it is astonishing that Balmes, who, for four years, read no other book than the summa of st. Thomas, saying that in it all truths are contained, should have departed from his master in this inportant point. st. Thomas says:

" Substantia est res, alujus natura debetur esse non in alio: accidens vero est res, eujus natura debetur esse in alio" ;1

and further:

- Illud proprie dicitur esse, quod habet ipsum esse, quasi in suo ase subsistens. Ende sola substantiae vere et proprie dicuntur intia. ${ }^{42}$

Ceo-Scholastics universally athere to this view, and are so far from regarding substance as a support of aceidents that some of them describe fiod as a substance which exists by itself, and to which no aceidents are nor can be joined. ${ }^{43}$

The scholastic theory on this point is moloubtedly right. Wo annot deny that experience presents us with two distinet clases of objects: some of which exist by themselves, while others cannot rxist but in something else. An object existing by itself, as a lamb, a 1 rore, grold, mycelf, is called an individual or a substance. In object existing only in something else, as walking, singing. grood health, color, is called an aceident or an attribute.

The words accident and attribute, although sometimes indis(riminately used, are not, strictly speiking, syllonymous. 'The worl attribute refors to an essential clement of a substanee, such as rason and a certaiubodily form in man; aceident, to an wement which an individual may lose without ceasing to be what it is ; sueh as health in man. The attribute is one of the con-

"Thomats Apuinas, Quolib. 9, a. 5, and 2.

"Thomas Aquinas, Summa Theol., P. i, Q. 90. a. 2.

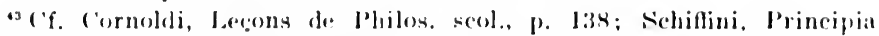

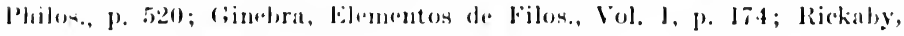
feneral Metaphysies, p. 2ust. 
stituent elements of a substance; the accident is not. As this distinction is not of capital importance for our present study, we shall not insist upon it any more.

Substance is thus identifiable with individual, and means a complete object. It is not an unknowable thing lying beyond the attributes; it is the attributes themselves. The essence, as Hegel says, must appear or shine forth. It is not proper, however, to call the substance a heap of attributes, because it is the substance, the attributes, that possesses individuality. Instead of defining the substance in terms of the attributes, we must define the attributes in terms of the substance.

Substance is that which exists by itself. Here we must return for a moment to an assumption of David Hume, of which we have already spoken. We have seen that the author of the Treatise on IIuman Nature admits our theory in its essential principle. But, as he regards everything as capable of existing by itself, and hence denies the existence of attributes, the conception of substance becomes meaningless in his hands, just as the expression "relative knowledge" becomes meaningless in the system of absolute relativity, just as the conception of subjective fact becomes meaningless if we adopt the position of the subjectivist.

An analysis of the facts of our world convinces us that substance is not, as Hume maintains, each individual impression or quality. Experience shows that these individual impressions do not, in point of fact, exist apart from each other. Hume's capital fallacy consists in arguing that what we may conceive as existing apart, may and does exist apart. If color, ete, existed apart from any other sensible qualities, it would, indeed, be a substance. And we do not deny that it might possibly exist in this manner. But the question is not whether it could, but whether it does so exist. And our eonstant experience shows that it does not. Experience must be our guide as to the nature of reality. Ilume overlooks this eapital truth, and thus sorely confuses the posible with the actual. A railroad may be con- 
reived at existing from bere to the moon, but it does not exist. llumes reasoning womld temd to prove that it does.

substanereand attrihutes are thes valid conceptions, and hear to each other the relation of whole, and part.

All other defintions of substance must be rejerted as incom-

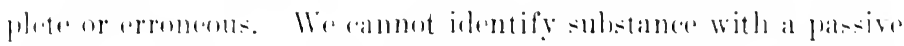
reepigent. as bereartes did, becallse experience proses beyond the fosibility of a dombt that substances, bodily as well as mental, are condewed with activity. Sugar acts upon our palate, a cheminal produet upon our blood, a peal of thunder upon our tymfanmm. No less active is mind. To its adetivity is due the whele progress, the whole civilization of the human ralee. Ixebl)niz: definition of substanee as " the being enelowed with activity" is certainly the "xperesion of a great truth. Pasivity. howerer, is another element of our miverse, indispensable to an adefunate aceount of reality. Some of the properties of matter, such as axtension and inertia, an hatdly be cxplained without taking passivity inte aleount. The fact of knowled are itself, althomerh involving an activity on our part. forces us fo renard

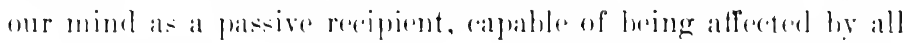
sorts of ohjeres ame necessarily determined hy the particular reality which guseseses the charaletere of evident truth.

Finally, with resarel to Kant sidentifeation of substaner with the fermanent in ehanere. we will simply remalk that a perma-

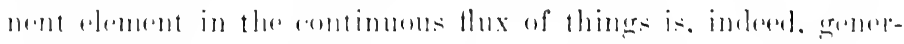

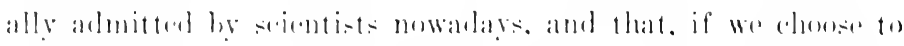

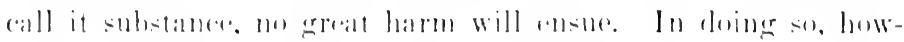

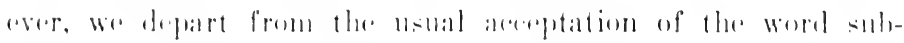

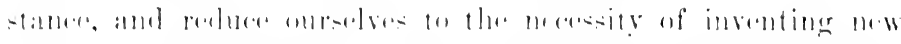

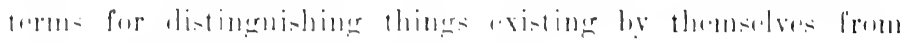
things asioting omly in somethiner alse.

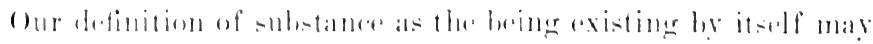
he interperend in different ways. It may be sald that finde.

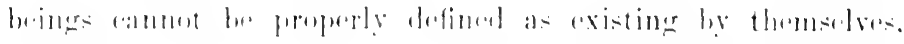

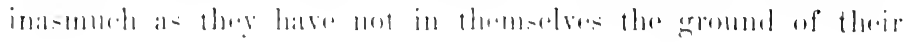


existence. God has created them and continually preserves them; and this preservation is a continual creation, so that, if it should cease, all things would be reduced to nothing. Finite beings are thus essentially contingent. They depend upon the knowledge and power of God, who is the only being really existing by itself.

This remark was passed by Descartes, who confessed that his definition of substance properly applied to God alone. Unwilling, however, to depart from the ordinary use of language, he admitted two orders of finite substances: bodies and spirits, and supposed that the essence of body consists in extension, the essence of spirit in thought. Spinoza took up Deseartes's idea, and was not dismayed by its pantheistic implieations. He defined substance as "that which is in itself and is conceived through itself; in other words, that of which a conception can be formed independently of any other conception," 44 and showed that God is the only substance. The same doctrine has been revived-with some important modifications-by Hegel and his sehool. All monistic idealists maintain that there is only one mind. They contend that; as all things are inter-related, they are parts of a single whole, which is the Absolute, and in which everything else has its reality, its meaning, its very being. A that, Bradley would say, is not a mere that: it also involves a what. And as any that is related to all the other thats, and hence to all the other whats, and thus comprises the whole series of thats and whats within its own what, it clearly follows that there is only one all-embracing what, which is the Absolute.

'This view, which closely resembles the Christian doctrine of the Deity, may certainly contain much truth. If there is a creative mind, whose knowledge is the cause of all things, as St. Thomas teaches, and of whom we are, as it were, the dreams, it is strictly true that there is only one individual, one all-embracing substance. But, whatever good grounds we may have for the existence of a supreme mind, we do not know it by intuition,

"Spinoza, Ethics, Bohn's ed., p. 45. 
and it is upon our knowledge of our own world, of the world we fossess here and now, that we build our philosephical conceptions. In this world, wo find many individuals which, although related to other beingr. are complete by themselves in the sense that we can think of them as independent of any other individual. 'This loals us to the problem of individuality.

For the Jonists, then, there is only one individual. 111 things: they raim, are so connected that an siugle object has no meaning apart from the rest. It is true that the same experienee which presents us with individuality, obliges us to reconnze antinuity. He ought not, however, to insist upon one of the clements of our experience and unduly discegard the other. Continuity exists; but, besides the fact that it fails to prove the existence of a mind in which all things are one, the doctrine of the identity of all thingsin the Absolute camnot have much meaning for our practical life, and appears to us as the night in which all cows are black.

F," The recognition of a variety of individuals, or substances, becomes therefere a necesity. But the question arises as to what the individual will be: and, on this point, the greatest diversity of opjinion still prevails. 'The most extreme view would recognize as individuals nothing but the ultimate subdivisons of being: the atoms in the inorganic realm, the cell among organtsms. Tan womld thus cease to be an individual and hecome a colony.

Coloser investigation of the nature of reality might perhaps reconcile all opposite views. Scerentifice insestigations seem to have established that all material beings are made up of identical ultimate farts, or electrons. It is likewise admitted that the inorganic and oreanic realms prosent no fundamental difference, and, instead of dividing ehemistry into inorganie and organie, as was done before, we now rearard it as essentially one.

The condusion to he derived from these sedentific discoveries is that the aleetron is the ultimate individual, not only in the mincral, hut also in the organic realm. 
A whole organism, however, is with equal propriety an individual, beeause it is a unique and complete being, with its own life, its proper operations, its peeuliar activity.

Finally, the molecule and the atom are also individuals; the former for the physicist, the latter for the chemist. The molecule cannot be divided by physical means. It possesses a unity of its own and is the individual about which the seience of physics is concerned. Chemistry, on the other hand, operates upon the atoms themselves. It is by combining them in different ways that it effects the various chemical transformations, that it produces the immense variety of compound substances.

We are thus compelled to distinguish different classes of individuals or substances, which do not exclude one another, but exist in such a way that the individual of a lower class is at the same time an element in the constitution of the individuals of the higher class. (This prineiple, we must here observe, does not unqualifiedly apply to God, as will be seen in the sequel.)

We have, accordingly:

1. The absolute individual, or God.

2. The organic individual, as man.

3. The physical individual, or the molecule.

4. The chemical individual, or the atom.

5. The ultimate individual, or the electron.

Our list purposely omits finite spirits, as angels, because as they do not fall within our experienee, and a knowledge of them cannot be reached by reason alone, philosophy is not eoncerned with them.

\section{Section 4.-Scholastic Theory of Cause}

According to Seholastic philosophy, cause is the principle upon which a thing depends in its heing or its heeoming. "Cause dicuntur ex quibus res dependit secundum esse vel fieri." ${ }^{45}$

${ }^{45}$ Mercier, Métaphysique genérale ou Ontologie, p. 529. 
Aristotle and the scholastics distinguish four kinds of causes: material, formal, eflicient and tinal.

The maturial and the formal canses are the constitutive principles of heings. As wo shall deal with them at srat length in our ehapter un cosmologe we shall alstain from treating of them now. (lur present study will therefore be linited the eflicient and the final callses.

In the opinion of the plain man, an etlicient caluse is that which really produees an effect. When the laborer drinks a glase of waller, and thus quenches his thirst, he believes that the thirst-quenehing not only oceurred after, but was produed by the aletion of the water.

It has berome a fashion in philosophy to deride the notions of the plain man. I stulent nowadays is often smiled at for his nairvete if he believes that his book is really in his desk when nobody pereceives it : he is looked upon as ignorant of the invarbahle laws of nature if he regalds his will als frees he is ridiculed as a fotich-worshiplere if he fows the slightest sympathy for the old dectrine of calusal power. For my part, I confess that I can hardly part from these naibe beliefs: and, at the risk of beiner mocked for not having wet bestriellen the threshold of philosophy I frankly take part with the plain man in his realism, his libertarianism, his helief in eflecieney.

The seholastic dectrine of eflicient callse has met two (dilseses of oppenents: some, following llume, have dropped out the eoncept of efliciency altogether and rediuced callsality to a mere

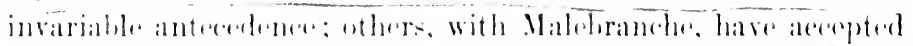
the gromine notion of ealles. hut they have limited it to the

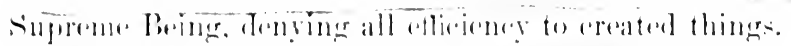

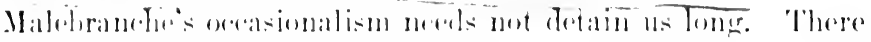
is actually bette danerer of limiting cansiality to fiod alone. In-

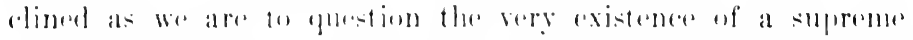
mind, we fert little sympathy for a sytem which considers this mind ats the only efliciont faretor in the worlet. 
We shall therefore limit ourselves to a few considerations which have been frequently urged against occasionalism.

1. Malebranche's fundamental principle that activity is proper to God alone and cannot be communicated to creatures, is devoid of foundation. God can do all that is intrinsically possible; and there is nothing so evidently possible as a creature endowed with activity.

2. God's wisdom manifests itself in the infinite variety of organisms we observe in the universe. From the molecule of the mineral to the elaborate body of man, there is a wonderful series of organized beings possessed of particular potentialities, endowed with a surprising adaptation of means to ends. The paw of the cat, for example, so perfectly adapted to the catching of the prey, is a marvel for the naturalist. Now, if finite beings possess no efficiency; if, when the cat stretches its paw, it is God that catches the mouse-as Malebranche would maintain-the intricate organization of created things becomes a useless machinery. The external world itself is altogether unnecessary; and, should it be annihilated, we would noways notice its disappearance.

3. Our own consciousness, which has been justly called the ultimate court of appeal in the science of mind, testifies that. whenever we act, our own course of action is in dependence upon our will. So little are we convinced that God acts in us, that we feel remorse whenever our action is not done in accordance with duty, and do not doubt that we can act otherwise in the future. It is true that Malebranche admits the freedom of the will; but, in so doing, he obeys his theological prejudices rather than the logic of his system.

Let us now pass to Humes theory of eausation, which is not. like Malebranche's, an object of interest to the antiquarian alone, but is still vivid among us; and, despite its shortcomings, does not seem as yet doomed to a speedy disappearance.

Hume's analysis of the idea of causation is often honored as his greatest contribution to philosophy. And it cannot be 
denied that it is a superb piece of work, that it evinces a remarkable power of analysis in its author. If we grant the original assumptions from which Hume starts, we are irresistibly lod, step by step, to his final conclusion. But, similar to an arehi-

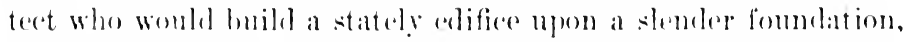
Hume has failed to prohe, in a sutfieient degree, the ground upon wheh he has been at work, so that his elaborately constructed mansion. in spite of the studied arrangement of its parts, affords no safe lombing to the traveler, whe foels compelled to shun it as hy a natural instinct.

The fundamental principle given by Hume at the outset, and wheh he keeps constantly in mind, is that all our idleas are derived from impressions."

He accordingly asks what impression produces the idlea of causation. It cannot he a quality of the object. "since, whichexer of these qualities I pitch on, I find some object that is not posiesed of it, and peet falls under the denomination of cause and effect." It must therefore be a relation amonge objects: ${ }^{48}$ and Hume is led to examine the different kinds of relation from which the idlea of caluation may arise. He at first discovers contiguity and successon. The does not. howerer, attach much importanes to this discosery: and, after a weak attempt to estahlish its truth ly reasoning. he tells to that, if his argument appears satis factory. it is well: if not, wo are begred to suppeses it such.:

He soon discovers, howerer, a necessary connection as the escential element of callsation: hut he does not at first find any light as to the real nature of this connedion, and resolves "to heat the neighboring fields, without any artain view or design. with the hope that his ceoced fortune will at last guide him to what he searches for. ${ }^{\cdots}$

"Hume, Treation on Iluman Nature, Sellyg-Biggen's ed.e p. 4.

"Miil., p. 75.

"Iticl.. p. 7.5

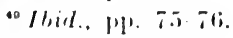

(a) Mlidl. P. Iti.

"Hoil.. p. is. 
An examination of the proposition that "Whatever has a beginning has also a cause of existence" convinces him that it expresses a principle neither intuitively nor demonstrably certain, and he triumphantly refutes it by the following argnment:

"As all distinct ideas are separable from each other, and as the ideas of cause and effect are evidently distinct, it will be easy for us to conceive any object to be non-existent this moment, and existent the next, without conjoining to it the distinct idea of cause or productive prineiple. The separation, therefore, of the idea of cause from that of a leginning of existence, is plainly possible for the imagination; and consequently the actual separation of these objects is so far possible, that it inplies no contradiction nor absurdity.'.’s2

The conclusion is that our belief in the necessity of a cause must he derived from experience, and Hume proceeds to examine the particular note of our experience to which the idea of causation may be due. When he least expected it, he discovers a new relation in which he eagerly hails the long-sought-for answer, and we are told that the necessary connection between cause and effect is their constant conjunction. ${ }^{53}$. It once, some interesting conclusions are drawn, viz, that we have no right to apply causation to future experience, inasmuch as we can conceive a change in the course of nature, and therefore that change is possible; also, that causal necessity is something that exists in the mind, not in objects. ${ }^{54}$

Hume does not, howerer, deny a power in the cause, nor a real production:

"We may remark," says he, "not only that two objects are connected by the relation of cause and effect when the one produees a motion or any action in the other, but also when it has a power of producing it ";,55

${ }^{82}$ Ibid., pp. 79-80.

sas Ibid., p. 8 i.

"Ibid., P. 16i5.

Ibid., p. 12. 
and further:

"It will always bo imposible to dedede with certainty whether they (the impresions) arise immediately from the object, or

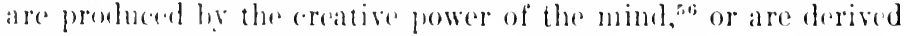
from the anthor of our being."

some incidental outhursts of homesty oven reveal him ats

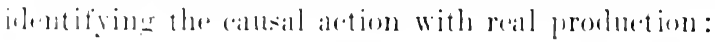

". Should any one prefend to define a cause hy sayine it is somblhine prouluetion of another, it is evident he would saly nothing. For what does he mean by production? ('an he grive any defintion of it, that will not le the same with that of causation: If he can, I desire it may he produced. If he ramnot: he here rums in a circle, and gives a senonrmons term instead of al definition."

Such fassages as this might tompt us to go and shale hands with Heme at onere. in the belief that we have at least come to an agreement. It womld not be prudent. howerer. to act too hastily. In a subsepuent chapter, the supposed power and efficaly of causes is ramined at great length. Humes origrinal assumption that all ideas are coppes of provions impressoms, there enviness him that "wo have no idea of power or eflecacy" ", that, when we use those worels, we have really no distinct meaning :"s" finally, that the power which mites canses and efferets resides in our mind. ${ }^{61}$

In his reduction of the causal action to a constant conjunction, Hume was-if we helieve him-actuated ly a most landable purpose. Ma intemeled to ricl philosophy of those mysterions entities, of these oceult pewers, which had so long rawled in the stud! of the lanrmed, and hald not geet been fully dispellad by the enlightenment of the new century.

in 11 remember that we hase no mind.

: Itidl., p. s.t.

"M llide, p. Ti.

- Ibid., pp. lo0 l61.

ollide, p. lfie.

"Ibid., p. 166. 
Unfortunately, it often happens that a mystery is replaced by another mystery greater than the first; that a most unreasonable demand on our power of faith is made by the very men who are sometimes so difficult to satisfy in matter of proof. This is exactly the case with David Hume. Motions and changes were satisfactorily accounted for in the old causal theory, and become a perfect mystery in his. Let us suppose that the erent $A$ has been followed by the erent B. As, according to Hume's assumption, the two events $\mathrm{A}$ and $\mathrm{B}$ may be coneeived as unconnected, we may neglect the element $A$, and reduce the series, $A, B$, to the series not-B, $B$. If we maintain the necessity of an efficient principle, we will explain the production of $B$ by the action of A; which, as Aristotle would say, contains B potentially. If we deny efficient action, we must maintain either that $B$ comes from nothing, or that it comes from not-B. But, as, on the one hand, from nothing nothing can come; and as, on the other hand, not-B simply denotes beings in which $\mathrm{B}$ does not enter as an element, no shadow of reason is given for the production of $B$, and we find ourselves face to face with a reality incomparably more mysterious than the causal principle which had heen discarded for its mysterious character.

Passing to a closer examination of Hume's theory, we will at once remark that his first principle: "all ideas are derived from impressions," not only is not self-evident, but is absolutely erroneous. It is true that all knowledge begins with senseexperience; but it does not follow that all ideas are copies of sense-impressions. If such were the case, we would never be able to step beyond the data of the senses; we would be incapable of forming universal concepts; even memories of past impressions would become inexplicable, and we could not attribute any reality but to the present instant. Our mental faculties are originally aroused into exercise by the data of the senses; but they possess an activity of their own which enables them to connect what sense-experience presents as unconnected; to reason ahout given data: to reach conclusions about nature which are 
implied in the natural facts, but are not directly given, and must be drawn by the active power of our mind.

Hume repeatedly maintains that the idea of cause implies a necessiary connection."

Now, constant ronjunction is mable to give us the idea of necessity. For, what does constant conjunction mean? Simply that in all singular past instances we olserved, two evonts happeened to be connected. Bach instance was a contingent fact indeprndent of all others. As we cannot step beyond the data furnished hy sense-pereption, we cannot reach any law of conneetion between the individual cases, which remain essentially. singular and unconnected: so that their multitude, howerer great it may bee is mable to alter their contingent character. Hume, it is true. grasped this consequence, and tried to explain our idea of the neessary character of the canse, not from an accumulation of individual cases, but from a natural propensity of our mind to pass from the idea of one olject to the idea of anothere: It would be interesting to know whether this profusity of the mind is drrived from sense-impressions or not. If it is. we hardly see how it can assme a character of neepsity. It cannot certainly ged it from the sense-impressions themselves, heraluse each impresion is a contingent fact unconnected with the rest. If, on the other hand, this propensity is not derived from sonse-impressons: if it is a natural and innate disposition, we have an idea not derived from impressions, and IIumes fundamental principle falls to the ground.

Horeover, the resolution of cause into constant conjunction presents the eapital blemish of discegarding, in the conception of ealuse. the causal element itself. Hume closely resembles a theatrical manager who would grive the play of Hamlet without the Prinese of lenmark.

constant conjundion and ofliciency are by no means identieal concepte. Constant conjunction means that an erent invariably

az Mirl., pp. is, is. ate.

as Midid., p. 92. 
comes after; efficiency means that the second event not only comes after, but is due to the first. There may be efficiency without constant conjunction, and constant conjunction without efficiency.

Constant conjunction between two events may take place without any action of the one upon the other when both events are due to a single cause. In nature, nigltt is invariably followed by day; but is not, on that aceount, regarded as its cause. Their constant conjunction is due to the fact that both night and day are produced by the suceessive positions of the sun.

In a mathematical series, such as:

$$
(I \times x)^{n}=I+n x+1 x^{2}+B x^{3}+\ldots,
$$

a definite term, $n x$, is invariahly followed by another definite term, $A x^{2}$. Their constant conjunction is due to the nature of the expression $(I+x)^{n}$, and by no means to anything like efficient action.

Efficiency, on the other hand, may appear without constant conjunction. It is true that it cannot thus appear in the realm of the necessary. Objects of nature are determined by their own potentialities to some definite effects; and, whenever they arc placed in suitable conditions, the reaction which oceurs gives rise to these effects. The like does not hold with regard to free agents. IIuman beings are persuaded of their own efficient action in singular instances, even when similar cases have never taken place in the past and are not likely to take place in the future. Only once did Lincoln sign the Emaneipation Proclamation. Nobody doubts the efficiency of his will in this momentous crisis of our history, although a similar conjuncture had never occurred before and will never oceur again. Lincoln might then have acted otherwise; and, should our country be placed in identical circumstances once nore, we clearly conceive that our president might take a different course of action. We would thus have identical antecedents, and different results, and would not hesitate, however, to attribute the result in both cases. to the efficient action of the hear of the nation. 
In physical nature itself. We often attribute aflicient action to oljects which hate not been invariably conjoined. In all our fast experienee, we may have observed that puinine is an excellent remedy for ferer. The ninety-nine patients to whom we administered it were in ditferent eiremstances with regard to age physical constitution and general health: but all presented the identical charaleter of heing aflected with ferer: and all, on taking quinine, were sublenty relieved. We thus feet no doubt as to the effiejent action of quinine, and a new patient having gent the salme discase, we have recourse to our nostrum again. linfortunately, as soon as the sick man has swallowed our favorite remedy, he feels worse and dies. The result is unmpereted. It is contrary to the previous course of things. There is certainly ne constant conjunction. Still, we cannot help attributing to quinine the deplorable erent. We feel sure that quinine has killed our sick man.

Etticiency and constant conjunetion ge together in the physieal world when one single agent is at work. But when sereral calleses are aleting in different directions. they may incidentally meet, and. by their conjunetion, grive rise to an unexperted result, which presents no nexesary commertion with any of the particular eatuses, and is simply attributed to chance, although

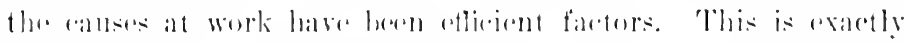
what happens in the atse of mer sick man. I chemist combl tell us beforehand the result of his experiments herease he has to de with materials diretly ateting 11 mon one another, and

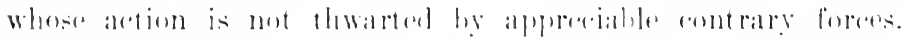

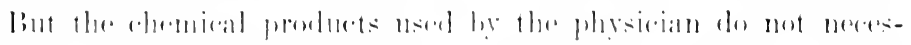

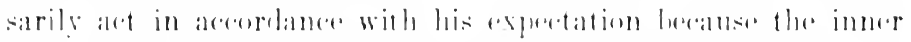

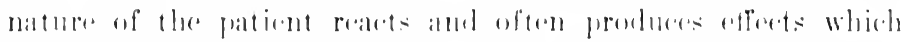

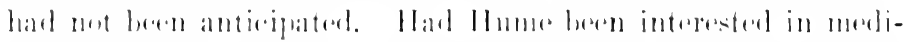
rine, he might hase felt some suspiefon as to the value of his

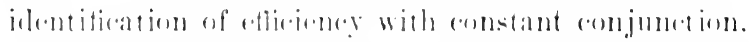

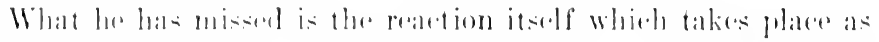

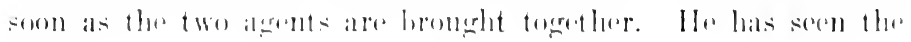


antecedent conditions, the subsequent result; he has overlooked the very instant in which the causal action occurs.

The philosophy of invariable sequence thus falls heavily to the ground under the weight of its unfounded assumptions and absurd consequences, without any hope of erer being able to rise again. The efficient action of Aristotle and the schoolmen, proud of its decisive victory, appears on the field anew as the only theory capable of giving a satisfactory account of experience. It shows us that in all cases in which a reaction takes place, a result not only follows some definite antecedents, but is due to their natural potentialities; that the quenching of fire follows the application of water precisely because water is endowed with a capacity for quenching fire; a capacity which other agents, such as cotton, do not possess, inasmuch as these agents, being placed in similar conditions, similar results do not follow.

The much ridiculed answer that opium causes sleep because it possesses a dormitive virtue, is not only the expression of common sense, but a highly philosophic truth. It is the best, nay the only answer that could possibly be given. Since Molière wrote his play, and the Parisian theatre-goers stupidly laughed at what the talent of the poet was able to present in so comical a light, the burst of laughter has spread all over the world. Everybody has jeered at the foolish reply; but. for powerful reasons, no one has ever been able to correct it.

'The problem of final causes has been sometimes formulated in the following picturesque form: 'The bird has wings, and it flies. Does it fly because it has wings, or has it wings to fly?

As Mgr. Mereier remarks, ${ }^{64}$ this formulation of the problem is unfortunate. It seems to imply that the efficient and the final causes exclude each other; a principle which all advocates of finality would undoubtedly reject.

The final cause may be defined as the good for the sake of

a Mercier, Metaphysique generale ou Ontologie, p. 481. 
which the officient anuse acts. "hoe dicimus esse finem in quod termelit impetus ayentis. ${ }^{\circ}$

The final cause may be considered in rational and irrational beings. In rational beings, it is a known and aecepted end which determines their present acts. Tn irrationat teings, it is a controlling factor. a natural end to which they irresistihly tend.

TII beings act for an end, and it is this end that determines their activity. Tf an agent were not tending to a definife end. it womld he indifferent towards acting in this or that way. and conserpuently would never begin to act.

The existence of final causes, thus demonst rable a priori, may equally be proved from experience. There is little doubt that conscious beings act with an end in view. The young man who wants to become a skilful physician begins be studying chemistry and anatomy a afterwards sulmits to a long and perhaps wearisome course in a medical school; voluntarily abstains from numberless enjoyments towards which he fols naturally inelined, but which would divert his attention from the geal he wants to reach; spends his days and a good part of his nights perusing bulky volumes which, in other circumstances, he would regard as sovereignly tedious. Why does this young man submit to such an irksome task? What enables him to throw off his natural indelenere? Simply the end he has in view. the good he purposes to obtain. This grood which, he its attraction, excreises such a powerful influener upon the aletivity of the student, is rvidently a cause.

In unconscious beings, there exists a similar detormining principle. The acorn huried in the ground tends to a definite end. If placed in a favorahle enviromment, it will not act at random, but will insensibly approach the groal it has been assigned by nature. Every suceededing day will witness a more complete aretualization of the oak, which at first existed only in a petential form. Only when this end is reatehed shall the

es Thrmal- Apuinias, contra cientiles, Lit, 3, cap. 2. 
tendency of the acorn cease; only then shall its final purpose be realized.

These considerations forcibly impose the final cause upon the attention of the philosopher. Even among defenders of modern thought, the old Scholastic problem of finality reappears. In a remarkable essay published in the Hibbert Journal, Mr. George Henslow quite recently developed a theory at bottom identical with the teaching of the schoolmen. He gave to the old causa finalis the name of "directivity":

"Suppose a kitten and a young hawk are brought up on precisely the same animal food, both being earnivorous, one develops into a cat, with fur, having bones and muscles, etc., of totally different character from those of the adult hawk, with feathers, ete. The same molecules of food supplied the materials for the building up of their bodies: why are the results so totally different? So, too, in all animals and vegetables: why should certain substances be guided to certain places-salts of lime to bones, silica to teeth and claws, phosphate to brain, etc. The molecules are first driven abont mechanically in the blood by certain forces; various chemical combinations are made under the action of other fores; but what direets all the forces which finally impel the new-made molecules to take up certain positions and no others in the building up of a body? Directivity is a useful word to express the fact. It commits one to nothing as to its souree; but it at least supplies a term to express the analogy between the chemist's mind and Natures-what? ${ }^{* 66}$

Scientists, it may be observed, lave final canses entircly out of account, and feel little more simpathy for efficient causes. It is the scientific development of modern times that has contributed more than anything else to the apparent discredit of the cansal theory. It might even be arkled that the wilful neglect of causal action has been a most efficient factor in the development of science. Why, then, should the metaphysician cling to a theory whose kownfall has been such a blessing to mankind?

"Henslow, Directivity; Hibbert Jourmal, Vol. (o (October, 1907), pp. $150-151$. 
Would it not be better to discard efficieney and finality from the field of philosophy as well as from the field of science?

No doubt this is a real diffieulty. It is the point which empiricists and positivists lore to emplasize. and it gives them so strong a foothold that, despite the ungrounded assumptions and irrational consequences of their system, they bravely hold their own. It must he remarked, however, that the scientist and the metaphysician have very different problems to face. science is concerned merely with facts and results. The (hemist has simply to establish the fact that, if two grams of hydrogen and sixteen grams of oxygen are brought together and submitted to the action of the electric spark, water will invariably follow. The biologist needs not go beyond the actual conditions necessary to the duplieation and development of the cell. For him, a monster is no less natural than a normal organism. Science, as Pasteur clearly pointed out, is essentially positivistic.

Put, does the seientifie position solve the enigma of the world? Does it satisfy our thirst for knowledge? Are there not many genuine problems which science does not approach? Why is the proportion ? to 16 necessary for the production of water? Why do organisms usually reach a normal derelopment, and are monsters so rare? 'These are questions which the metaphysician alone is able to answer. He alone is concerned with the ultimate nature of reality. He alone profeseses to make a thinking study of things. The scientist formulates the law that an embryo placed in such and such areumstances will develop into such an organism. 'The motaphysician takes up these socientific facts, studies their mutual connections and implications, and is led by the facts themselves to the conclusion that the embryo" does not develop at random, hut is constantly controlled and temls to a definite result. 


\section{CHAP'TER IV}

\section{SCHOLASTIC COSNIOLOGY}

\section{Section 1.-Chief Hypotheses as to the Constitution of}

Matter

The question of the constitution of matter is one of those fundamental problems which, in the course of human investigation, have been most widely discussed, and of which an adequate solution will perhaps never be attained. It is one of those questions before which, aceording to Herbert Spencer, human reason must humbly confess its powerlessness; a question which seems to prove a mystery for the human mind and to point to the existence of the unknowable in nature.

All attempts at a solution of this great problem may be classified under two heads: they are all, in some way, connected with the two theories of Atomism and Dynamism.

The atomistic theory sprung originally from ancient Greece. According to Aristotle and Theophrastus, it is to Leucippus that we must attribute the honor of its discovery. But, as we know so little of Leucippus, and as his very existence has even been called into doubt, ${ }^{1}$ we generally consider Democritus, his illustrious disciple, as the founder of the system.

The loss of all the writings of Democritus is indeed one of the most deplorable facts in the history of human investigation. With what burning interest would we not follow the efforts of his genius to get rid of the untenable hypotheses of his contemporaries and to reach a satisfactory exposition of the intrinsic nature of things! And still, deplorable though it be, such a loss is unhappily a fact; and our only substitute for a study of the philosophy of Democritus is to turn to its poetical exposi-

${ }^{1}$ ('f. John Burnet, Early Greek Philosophy, p. 350. 
tion, as given by Lucretius in his justly admired poem $D_{e}$ Rerum Nature.

The atomistic theory has undergone, in the course of time, many profound modifications. Hard atoms and absolute void were the only elements which Democritus supposed to exist in nature. In recent times, there has arisen the idea of a universal medium, of a fluid everywhere present, penctrating all bodies, and serving as a connecting-link between the atoms.

The existence of the ether is indeed only a hypothesis, but it is a hypothesis that has been rendered very probable by scientific discoveries: and now, it may almost be considered as an established fact. At present we will not discuss the probabilities in favor of each of the particular ether theories that have been brought forward. This theme will be fully treated in one of the ensuing sections of this chapter. Suffiee it to say that, although all physicists do not agree as to the inherent constitution of ether, they all unanimously aflirm its existence.

Atomism almits only matter and passive emotion in nature. Still, a majority of thinkers did not deem these two elements sufficient to aceount for the activity which our everyday experience shows us to exist in the universe, and therefore they thought it indispensable to introduce into nature the alement of foree. And thus the theory of Iynamism originated.

We shall refrain from presenting the various theories held by the ancient Greek:, which might be termed dynamic. We shall not even tonch upon Leibniz's famous doctrine of monads, but we shall consider as the true representative of Iynamism the Jesuit Boscorich. Instean of the hypothesis of hard atoms. Boscovich proposed to consider nature as formed of unextended points, of indivisible cunters of force. Which mutually at tract and repel ach other, are therefore capable of furnishing a satisfactory explanation of the activity manifested in nature, and give us the illusion of continuous extension, in the same way ats points placed very near wach other might lead us to believe in their forming contimusus letters. 
Seholastic cosmology might be described as an intermediate position between the two systems just outlined. Its defenders reproach atomists for denying activity to nature, and contend that in explanation of att the phenomena of the world by mere matter and passive motion is forever doomed to remain a fruitless attempt. On the other hand, they consider the dynamic view to be similarly inadequate. They assert that, although passivity cannot be the only element in nature, its very existence must not be denied, and they put forward the theory of Matter and Form as the only possible explanation of the universe.

I must here confess that I have never felt for the theory of Matter and Form that unreserved sympathetic feeling wherewith I have subscribed to so many Scholastic doctrines. I cannot help regarding the Thomistic eosmology as arbitrary, assailable in many points, inconsistent with our advanced scientifie discoveries. The fact that physies and ehemistry unanimously adhere to some form of atomism is of great significance. Scholasties are perfectly justified in insisting on the shorteomings of Atomism and Dynamism. They are right when they assert that activity, as well as passivity, must be admitted in the composition of our world. Unhappily, the theory they propose does not rest upon cogent reasons, and therefore it should be frankly rejected, or made to undergo important modifications.

The most cursory observation, Scholastics would say, suffices to show in all matter the element of quantity. $\bar{A}$ solid may become a liquid and a liquid a gas. A body may be made to assume an infinite number of forms: its volume may be increased or decreased; it may, by chemical combination, aequire a nature utterly different from the one it formerly possessed; but in all these transformations, in all these fundamental changes, there remains the element of quantity, unchanged and unchangeable, always identical with itself, and which thus seems to be a common element in all material things.

On the other hand, we cannot help observing the greatest diversity in nature. We find in every object an immense num- 


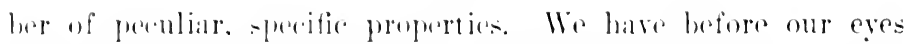
the great division of hodies into inoreanic and organie. In the

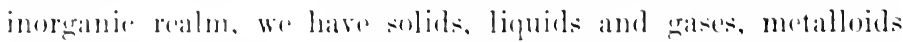
and motals. the simple elements which ehemistry has found to exist. amb whose number is daly increased by seientific research. We have the immunerable combinations of those elements, and the alpearanee in eompound bedies of properties essentially different from those of their simple constituents.

Ind if we turn our eyes to the sphere of life, if we ennsider the intinite rhain of living heings, from the amobal swimming in our blood to the more highly-developed boly of man-subjects of inexhanstible researeh to the scientific mind-are we not struck with wonder and amazement?

When we consider with a philosophic mind these properties of matter, we see that its qualitative varicty and its quantitative identity are cliametrially opyosite. It is this opjosition that led the scholasties to affirm that such properties must be the result of different principles.

Another argument in favor of the existence of Matter and Form, at laist as strongly insisted upon as the one we have just explained, is derived from the supposed essential transformations that take place in rhemical combinations: "I)ans re fat bien compris et sagement interpréte. says Mr. Nyse est contenme comme en germe tomte la thérie de libele sur la nature des corps.",

In a chemingl combination, sibholastics are prone to say, something remains and something is rhanged. That something is hanged-or, in other words, that a mew substanoe is produededis provere beyome any doubt by the fact that the physial properties of the ampound ditfer escontially from those of their eonstiturint elements. It is no less true that something remains, for otherwise we wonth not have a rhange, hut a real creation. The new alement is a substantial part of the eompound, heramse

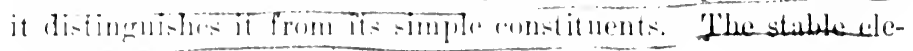

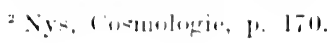


ment is also a substantial part of the eompound. It is the determinable principle which, actuated by the new element, has given rise to a new substance. The new element is the substantial form; the stable element, primordial matter.

Francisco Ginebra, following Thomas Aquinas, gives of Matter and Form the following definitions:

"Form is the incomplete substance which determines matter and eonstitutes it in a determinate species. Matter is the incomplete material substance which, actuated by the substantial form, produces a complete corporeal substance.",3

- Matter is then, in the Seholastic system, the passive element of objects. It is the same in all material things, which acquire their diversity by means of the substantial form. But primordial matter cannot exist in a state of isolation; it is necessarily united to the substantial form, and the infinite variety of these forms is the cause of all the diversity we behold in nature.

\section{Section 2.-Nature and Properties of Primordial Matter}

To have a fair idea of what Primordial Matter is-or, to speak more definitely, of what is meant by that term-is indeed a most arduous task, one whose diffieulty is enhaneed still further by the unsubstantial and indefinite character of the eonception itself.

This difficulty is reeognized by all Seholastic philosophers and frankly admitted by one of the most ardent sympathizers of peripatetic philosophy, Barthélemy Saint-Hilaire:

"As to these abstractions," says he in the Preface to his Physies, "the most difficult point is to understand them; but, onee understood, they appear neither false nor useless. Therefore, instead of rejecting this formula, one must endeavor to know what it signifies."

Albert Farges, in his most valuable work on the subject,

${ }^{3}$ Ginebra, Elementos de Filosofia, Vol. 1, p. 200.

‘ Saint-IIilaire, Physique, Préface, p. 38. 
deems it helpful to give us at first a negative definition: "To sily what Primordial Matter is not. saly he, is a very eats thing." He then proceds to show that it is neither a substance nor an accident: and that, for this reason, it cannot fall within the group of Aristotle's categories:

" (an primordial matter be clasised als one of the categories? It is clear that it cannot; as it is neither an attribute nor a complete sulstince, and ategories do not comprise but these two sorts of realities." ${ }^{\circ}$

This passage is of the utmost importanee, for Aristotle himsolf understood by categories the supreme genera to which the ideas of all things could be reduced, and the same view is still held by Scholastic philnsophers. We are thus led to the view that primordial matter is not a reality.

The doubtful character of the existence of primordial matter was folt even in the Iliddle Ages. From the very works of the founders of Scholastic philosophy, many extracts might be adduced, to show how slender was the foundation whereon Scholastic cosmology was reared. St. Thomas Aquinas, in his oplus(nle entitled I) principics nature. nakes the following significant assortion :

"Materia dicitur quod habet esse ex eo qued sibi adrenit, quia de se eso incompletum, immo nullum esse habet."

It is here claarly stated that primordial matter not only has: an incomplete being. but has no being at all.

In the summa contra Cientiles, the Angrelic Doetor speaks again in almost the same way:

"I psum esse, says he, " non est proprius actus materiae, sed

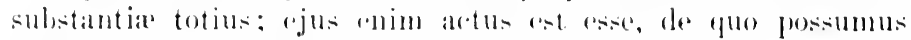
dicere quod sit. Esere autem non diritur de material sed de toto..$" n$

Farpen, Mattiere at Forme, p. 134.

- Ibid.. p. 1399.

"Thomat Aguinia, 1) principiis natura", xxxi, in init.

"Thomar Aquinats, Summa contra cientiles, lib. 2, rap. it. 
Other similar statements are quoted and discussed by Duns Scotus. In his treatise De Rerum Principio (Quastio VII), he warns us against the teaching of a few authors who seem to regard primordial matter as a mere potentiality without an actual existence. Among the philosophers he thus mentions, we find the names of Plato, Aristotle, and St. Augustine. But these writers do not, accorling to Scotus, really teach that primordial matter does not exist. They simply have in mind the fact that, of all existing things, it has the smallest degree of actuality.

Scotus then passes to a direct proof of the existence of primordial matter, and brings two classes of arguments: the first from authority, the second from the light of reason.

The proofs taken by him from reason are four in number and read thus:

1. "Si materia non esset aliqua res actu, ejus entitas non distingueretur ab entitate et actualitate forma, et sic nullam realem compositionem faceret cum ea."

2. "Inter ens actu et nihil, non est medium; ergo si materia præter formam non habet aliquem actum essendi, erit nihil; ergo agens creatum ageret de nihilo, cum agat de materia."

3. "Secundum Philosophos, materia est in potentia ad alia; sed secundum eos, nihil ad nihil est in potentia: ergo materia, ut materia, non est nihil; ergo habet aliquem actum de se, et si non subsistentix, tamen existentix."

4. "Item, posse pati ad materiam reducitur, sicut agere ad formam; sed quod non est aliquid actu, non est principium patiendi, nee fundamentum; ergo necessario materia habet actualitatem aliam ab actualitate forma, in qua actualitate forma fundantur, et stabiliuntur."

These four proofs are simply intended to demonstrate that, if we admit the theory of matter and form, we must regard primorlial matter as something actual. There is, however, another alternative: the rejection of the theory of matter and form. This alternative, unhappily, Duns Scotus does not consider.

- Duns Scotus, De Rerum Principio, Q. $\bar{i}$, art. 1. 
At the rish of intruling too much upon the patience of our rearlars, we will reproduce the words of a desoted seeker after truth, of a man who strove during his whole life to reach a satisfactory knowledge of nature, to nolderstand in a clear and definite way what, in the thought of his time, was still obscure and indetinite. St. Augustine, in that sublime work which is not only a humble anfersion of his life and a profound study of the human heart, but likewise a treatise in which the philosofly of his time is exposed and skillfully analyoed, considers thus the question of matter and form:

" But I, Lord, if I would, by my tongue and my pen, confess unto thee the whole, whatever 'Thyself hath taught me of that matter-the name whereof hearing before, and not understanding, when they who understood it not, told me of it, se I conceived of it as having inmmerable forms and diverse, and therefore did not conceive it at all, my mind tosicel up and down foul and horrible 'forms' out of all order, but yet 'forms': and I called it without form, not that it wanted all form, hut becanse it had such as my mind would, if presented to it, turn from, as unwonted and jarring, and human fraliness would be troubled at And still that which I conceived was without form, not as being deprived of all form, hut in comparison of more beautiful forms: and true reason did persuade me, that I must utterly uncase it of all remnants of form whaterever, if l would concoive matter absolutely without form; and I rould not: for -mener eould I imagrine that not to be at all, which should be deprived of all form, than conceive at thing betwixt form and nothing, neither formed, nor nothing, al formlese almost nothing,."

Wre enjecture that the state of mind which sit. Augustine here deseribes as having leen his awn has also been experieneed hy many a stulent who has tried to represent to himself dearly and distinctly what primordial matter is. It appears, in one form or other, in the writings of all the masters of seholastirism, who, although they unamimousty mantain that primordial

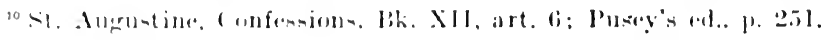


matter actually exists, cannot fail to recognize that its actuality is indeed very weak, and even to drop here and there a word tending to show that it has really no actuality at all.

Let us now pass to a positive exposition of the nature and properties of primordial matter.

In the foregoing section of this chapter we have given the following definition, which would be accepted by all Scholastics: Matter is the incomplete material substance which, actuated by the substantial form, produces a complete corporeal substance.

All substances, according to this view, are composed of two real, distinct, unisolable principles: matter and form. Matter is the same in all bodies, and it is form, and form alone, that is the cause of the infinite variety of material things: "Omnium generabilium et corruptibilium est eadem materia." 11 Matter and form, on account of their unisolable character, are incomplete substances, and it is from their mutual union that complete corporeal substances arise.

Changes in things are classified as accidental or essential. In accidental changes, such as occur in physical processes, the form remains identical with itself. But in essential changes, such as chemical combinations, matter alone remains. The substantial form which existed before the combination ceases to exist, and there arises a new form as the cause of the new substance of which experience evidences the appearance.

The fact of chemical combination plays an important part in Scholastic cosmology; and, although a few Mediæval philosophers, such as Albert the Great, taught that the elements remained in the compound, and one of the greatest among the neo-Scholastics, Liberatore, holds that the theory of essential changes in chemical processes is not necessarily connected with the Scholastic system, it is nevertheless incontrovertible that the great majority of Scholasties admit in chemical combinations an essential transformation, and we have seen how Mr. Nys bases

"Thomas Afiuinas, Summa Theol., P. 1, Q. 56. 
on this very transformation his strongest argument for the existence of matter and form.

According to this view, oxygen and hydrogen do not really exist in water, at there takes place, in the act of combination, a real change of nature. The only means of knowing the truth in this matter is experience: but the most powerful microsenpes show us, in the particles of a compound, the most perfect homogeneity, and the discolvents of its simple clements have upon it no effect whatsoeser. The atomistie view that an atom of water is a mere juxtaposition of two atoms of hyedrogen and one of oxygen is consequently pronounced to be arbitrary and unscientifie, and unable to account for the essential differener which exists between a simple mixture and a combination.

And here Farges brings forth the example of gunpowder, in which the three elements of saltpeter, sulphur and carbon are so intimately intermingled that no microscope cnables us to discern their presence. Still, the heterogeneity of the compound and its character of mixture (an be shown by means of disolvents. Water disolves saltpeter and has no etfect whatever upon sulphur and carbon; then another chemical product may eliminate sulphur, leaving carbon in a state of isolation.

On the other hand, no dissolvent of the elements of a chemieal combination has any effeet upon the compound. It: homogeneons character remains unaltered, and the only means of separating its elements is another chemical operation.

Mr. Farges endows primordial matter with the following propertics: indestructibility, simplicity of essence, identity in all material substances, parsivity, quantitativeness, impenetrability, need of a substantial form.."

" Primordial matter is indestructible. and cannot rease to exist unless it be annihilated by an act or Divine Omminotence.

It is simple as recrards its essenere, but essentially multiplo in it: parts. It is the cause of the extension and divisibility of bedics: it is the principle of quantits.

"2f. Farges, Matière ct Forme, 2. Partie, p. $143 \mathrm{tl}$. 
It is identical in all material substances, which, as we have scen, are distinguished from one another by means of the substantial form. Primordial matter is therefore the principle of all that which is common to all material substances, namely extension, divisibility, impenetrability, quantity, ete.

In all objects, it constitutes the passive principle, the principle of inertia, whereas the substantial form is the principle of activity.

Finally, primordial matter, not being able to exist in a state of isolation, stands, by the same fact, in need of a substantial form. Still, matter does not join itself indistinctly to any kind of form, but has a special aptitude to choose the form which suits it best. And we are thus led to the theory of the hierarchy of forms, corresponding to the various degrees of perfection and development in primordial matter.

"The more elevated in the hierarchy of beings the form is," says Farges, "the more must matter be prepared by a series of intermediate forms, which gradually dispose and elevate it. And this is true in the order of physico-chemical phenomena as well as in the biological order. And in no case could disproportionate elements be united, as, for example, a human soul with the organism of an ape." ${ }^{13}$

'Thus far we have spoken of primordial matter in a general way, without taking into account the various divisions given by Scholastic philosophers, both in the Middle Ages and in our own day. We do not think these divisions indispensable to a thorough comprehension of the theory, and neo-Scholasties are unanimous in considering many of them as useless subtleties. We cannot, however, abstain from enumerating the most important among them, and we feel confident that such an cnumeration will give a more comprehensive view of Scholastie thought, and easily make us understand the drift of that teaching.

The first division which suggests itself is that of primordial and sceondary matter.

${ }^{13}$ Farges, Matiore et Forme, p. 147. 
Siendary matter is the complete material substance modifiabfe by accilents. ats, for eximple. any chemieal substance. Primordial matter is the incomplete material sulstane which, actuatid by the suhstantial form, produces a complete corporesil sulistancere ${ }^{14}$

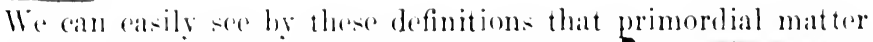
alone is matter strictly speaking. The so-called secondary matter is any material object as it exists in nature, after having ben actuated by the subtantial form: it is matter as understood by the plain man, but it must be carefully distinguished from the materia prima of the schoolmen.

Another woll-known division of matter is the out of which. the in uhich, and the about which.

Primordial matter is out of which relatively to the completw substance, or to the substantial form which is educed from it. The hody of a hrute. for example, is the matter out of which it: soul is wolvel. No! /

Primordial matter is in which with regard to the substantial form considered as united with it, and forming with it a complete substance. In this sense, the body of a brute is the matter in which its soul exists in a state of indissoluble union.

Finally, primordial matter is about which with regard to the efficient aluse hy whose action it is produced. The body of a brute is thus the matter alout whieh generation is concermecl.

Matter out of which has also been subdivided into folsing and persistent matter. Thus, the matter of the wood submitted to the aretion of the fire is passing: while the matter of the wood used by the carpenter to manufarture a piece of furniture is persistent." Not only is this sublisision of little aleount, but it serms to be based upen a wrong interpretation of the terms. inasmmeh as primordial matter is persistent in both cases, and that which is really passing is the substantial form.

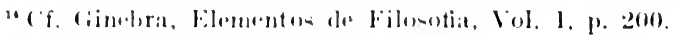

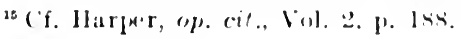


But the divisions of matter which show Mediæval subtlety at its best are to be found in Duns Scotus.

A singular view on this subject had already appeared in the eleventh century. The celebrated Jewish philosopher, Ibn Gabirol, had advanced in his principal work, Fons Vita, a startling theory of universal matter, according to which all substances, spiritual as well as material, were to be regarded as composed of matter and form. ${ }^{16}$ This strange doctrine was later on adopted by some Christian writers and became one of the leading characteristics of the Franciscan school.

Almost two centuries after the death of Ibn Gabirol, the first Franciscan teacher of theology in the University of Paris, Alexander of Hales, expressedly taught in his Summa Theologice that spiritual substances are composed of matter "quæ nec est subjecta motui nec contrarietati." 17 The same view was maintained by St. Bonaventure, ${ }^{18}$ and also by Duns Scotus:

“Ego autem ad positionem Avicembroni redeo; et primam partem, scilicet quod in omnibus creatis per se subsistentibus tam corporalibus quam spiritualibus sit una materia, teneo, sicut ostensi in præcedenti quæstione." ${ }^{19}$

With that distinguishing subtlety which forms the essential characteristic of his philosophy, Duns Scotus introduces a new division of the materia prima. He divides it into materia primo-prima, materia secundo-prima, and materia tertio-prima.

The materia primo-prima, or materia metaphysica, seems to be identical with the universal matter of Ibn Gabirol and of the Franciscan teachers. It is absolutely indeterminate and exists in all beings, incorporeal as well as corporeal.

The materia secundo-prima, or materia mathematica, is defined as the subject of generation and corruption:

${ }^{10}$ Fons Vita, V, 21.

${ }^{17}$ ('f. Turner, History of Philosophy, p. 327 .

"In 2. Sent., Dis. 3, 1'. 1, art. 1.

${ }^{10}$ Juns Seotus, De Rerum Principio, Q. 8, art. 4; Opera, Vol. 4, p. 378. 
" Est subjectum generationis et corruptionis, quam mutant agentia creatia, seu Angeli seu agentia corruptibilia."so

The materia tertio-prima is defined as the matter of any particular natural agent:

"I)icitur autem materia tertioprina materia cujuscumque arti., et materia cujuslibet agentis naturalis particularis, quia omne tale agit veluti de aliquo semine, quod quamvis materia prima sit respectu omnium, que per artem producuntur, supponit tamen materiam, quie est subjectum generationis, et ulterius aliquam formam per naturam productam, aliter nulla ars quidquam operatur."21

To simm up in a few words:

The materia primo-prima, or metaphysieal matter, constitutes the passive principle of all finite beings, spiritual as woll as inaterial.

The materia secundo-prima is the passive principle of corporeal substances only, and is called mathematical because it is the base of cxtension and quantity.

The materia tertio-prima is the matter of the plain man, and does not differ from what we have elsewhere termed secondary matter.

Sectos 3.-Nitere avi Propheties of the sibstanthl ForM

Chintrated with primordial matter, or the passive principle of all things, there is in them all an active principle called sub-tantial form. It is the form that callece all beings to be what they are, that ranges them in determinate spectesy Enlike mattor, it is mot the sime corerywhere, but is found with a greater or less degree of furferetion aceording to the exeellence of the heing it constitutes. There is therefore a countless multitude of substantial forms correlative to the multiplicity of things.

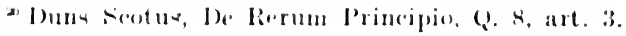

"Ilide, ibirl. 
Inorganic bodies possess forms of the lowest order, and we reach more perfect forms as we ascend in the scale of beings. In the vegetable kingdom, the form is the regetative soul, also called the principle of life; in animals, it is the sensitive soul, far more perfect, material however and doomed to perish with the animal frame to which it is joined. In man, the substantial form is the spiritual soul, which is, by its nature, intrinsically independent of matter, and cannot be affected by the death of the body. Although changeable in its operations and capable of development, it is, as to its essence, absolutely immutable and. by consequence, destined to continue in existence throughout all eternity.

Besides the substantial form, Scholastics admit accidental forms which, like color, figure, etc., are accidents which modify the complete substance.

In the foregoing section, we have already hinted at some of the properties of the substantial form. We have spoken of the hierarchy of forms, corresponding to the various degrees of perfection in primordial matter. We have also seen that, whereas matter is in all things the passive principle, the substantial form is the principle of activity:

"The first essential attribute of the form is to be the principle and the source of the activity or energy which we find in corporeal substances, now in potency, now in actual operation." 2

Of the remaining properties of the substantial form, the most important are the following two: its simplicity, and its need of primordial matter.

The latter may have been easily inferred from the exposition given in the preceding section. Like primordial matter, the substantial form does not and cannot exist by itself in nature:

"The material form has an innate need, and, if such a figure be allowed, a natural desire, 'appetitus naturalis' for matter, because, according to the will of the Creator, it cannot exist

2 Farges, Matière et Forme, p. 126. 
without that natural complement which grives it a body. a definite place and a sensible expression."

About this unisolable character of the substantial form perfect unanimity does not. however, exist among the sehoolmen. All Scholastices are unanimous in maintaining that the form is esentially joined to the matter in all corporeal things: hut whether the same holds true of spiritual beinges is a very controverted guestion. We have seen how Duns sicotus, following Ibn Gabirol and the Francisean sehool, attributes matter to all heings: and torms materia primo-prima what might be deceribed as immaterial matter.

The great majority of Scholastic philosophers reject I)uns Sientus's theory on this point, and attirm with st. 'Themats that, in spiritual beings, form exists without matter. But as, according to st. Thomas, matter, and not form. is the prineiple of individuation, it follows that there cannot exist two angels of the same species. St. Thomas unequivocally admits the inference:

"si eroo angeli non sunt compositi ex material, ot forma, ut dictum est supra, sequitur quod impossibile sit, esse duos angolos unius speciei : sicut etiam imposibile esset dieere, yuod essent plures albedines separatas, aut plures humanitates, cum albedines non sint plures, nisi secundum quod sunt in plurihus substantiis., ${ }^{24}$

This deduction might lead us to condude that, at the death of the body, human souls will be deprived of the principle that made them selarate individuals and will be one and the same. Surh a conclusion womld either overthrow st. 'Thomas's theorlegrical view of eternal life, or be a reductio ad alsurdum of his theory of form. But he meets the ohjection with a most remarkable subtlety by saying that the souls of men will aver remain distinct. because, although they will be separated from their material frames, they will still retain a certain habitudo

"Ihid., p. 1:34.

"Thomas Aquinas. Summa Theologica, Pars 1, Q. 50, art. 4, c. 
ad corpus which will be sufficient to distinguish them from other souls.

The remaining property of the substantial form is its simplicity. It has been remarked that primordial matter, although it is the principle of quantity and divisibility, possesses a certain simplicity. It is simple in its essence and essentially multiple in its parts. The substantial form is likewise simple in its essence, but, unlike primordial matter, it is endowed with simplicity as regards its parts.

On this point an explanation seems, however, indispensable. All material beings fall under two great classes: they are either organic or inorganic. An organic being is admitted by all Scholastics to be really one; hence it possesses but one form; but inorganic beings are not endowed with the same character of unity. They are merely aggregates of simple parts, called molecules or atoms, each of which has its own individual existence. It is therefore to the molecule or to the atom that the simplicity of form belongs.

Simplicity of form understood in this manner has been unanimously accepted in the school; but a certain number of philosophers have thought it necessary to admit in organic beings some subordinate forms destined, not to destroy the simplicity which the substantial form possesses, but to give more consistency to some points which, in the ordinary Scholastic doctrine, seemed to be inconsistent.

The doctrine of the plurality of forms was maintained by Henry of Ghent. He admitted in man, besides the rational soul, a subordinate form, which he named forma corporeitatis or mixtionis, and to which he attributed the function of causing the great variety of our organs and the substantial organization of matter. He proved its existence by the following argument:

"Aliter enim nihil homo in generatione hominis generaret substantiale, sed tantummodo corrumperet."2s

* Quodlibet, 111, 16. Cf. Turner, History of Philosophy, p. 385. 
This forma curporeitatis was said to exist in the embryo before the appearance of the spiritual soul, and to continue to exist in the hody after death, until decomposition takes place.

Not long afterwards the same dectrine was rendered nomous by Iluns scotus. This subtle thinker maintained that the substantial form determines matter to a mode of being, but does not determine it perfeetly, and leaves in it a certain potentiality, or aptitude for a higher form. And when matter arrives at the possession of this higher form, the inferior form continues to be present; so that, the more perfect the matter is, the greater the plurality of forms with which it is endowed. ${ }^{23}$

The same view appeared, in a more or less modified form, in later Scholastic thought. Iessius, Conninck, Mayr and others admitted in animals a certain number of partial forms, which they called forms of the bones, of the flesh, of the eyes, ete. They similarly spoke of the forms of leaves and roots in plants. However, the great majority of Scholastics, following st. Thomas, teach that living organisms cannot possess more than one substantial form. They assert that the forma corporeitatis is impossible and unnecessary.

It is impossible because if it were a substantial form animating the body before the appearance of the spiritual soul, as its supporters maintain, the spiritual soul, inasmuch as it would thus be united to a substance already complete, could not be a substantial, but only an accidental form.

It is unnecessiry, because, according to Seholastic philosophy, a form of a higher order gives to the matter to which it is joined not only the characteristic properties it possesses by its nature, but also all properties belonging to the forms of a lower order. Our spiritual soul, for instance, gives us not only spiritual faculties, but also the sensitive faculties of the brute and the vegetative life of the plant. ${ }^{27}$

This exposition of the theory of the substantial form demands

* ('f. Duns Seotus, De Rerum principio, Q. 8, art. 4.

" ('f. Irraburn, Compendium Philosophia Scholastica, Vol. 4, pp. 29 fr. 
as a complement a few words about a formula often met with in Scholastic treatises: Forma educitur e potentia materice.

With the exception of the human soul, all substantial forms are iffrinsleally dependent on matter, and, for this reason, are called material. Still, they do not exist in matter actually, but potentially; for otherwise changes would be only accidental, not substantial. These forms are not created, inasmuch as creation is the production of a being from nothing, and substantial forms are produced out of preëxisting matter. Now, observing what occurs in substantial changes, we see that, in order that the change may take place, it must be accompanied by some rleterminate conditions. On the appearance of these conditions a new substance is produced. This mode of production is what Scholastics call eduction out of the potency of matter. ${ }^{28}$ The spiritual soul alone is not educed in this manner. Being by its nature spiritual, it is intrinsically independent of the body and is created immediately by God.

\section{Section 4.-Modern Science and the Constitution of Matter}

It is only with the greatest reserve that one can enter on discussing the constitution of matter. So many brilliant minds have grappled with this stupendous problem, only to give up its solution in despair, that many think it a mere waste of time to try to drag Nature's secret from her pent-up bosom.

Such a proceeding, however, is but the position of despair and can hardly be justified.

Any existing thing can be understood, because to understand (intus legere) is to know a thing as it is, to read its most inti. mate nature. It is not meant by this assertion that, in our actual condition, we can be omniscient. Things which do not fall within the sphere of our experience will forever remain unknown to us; but, in the constitution of this material world,

${ }^{28}$ Cf. Thomas Aquinas, De Potentia, Q. 3, art. 8. 
there is apparently nothing lying beyond the grasp of our intellectual powers. An adequate explanation of the enstitution of matter does not therefore seem an impossibility, although we frankly admit that it has not been yet reached, and we doubt whether our trimmph on this point will ever he complete.

It has always seemed to us that Dynamism is somewhat faneiful, and the relatively small number of followers it has gained among men of science cannot but confirm us in the same view.

According to P. (i. 'Tait, ${ }^{29}$ the most fatal objection to which it is exposed is that it is incapable of explaining inertia, a distinctive-perhaps the most distinctive-property of matter. This remark is not absolutely devoid of value, as the manner in which I) ynamism accounts for inertia seems rather arbitrary. Still, we do not think that Tait does full justice to his opponents' view, nor can it be maintained that the drnamic explanation of inertia is altogether valueless.

According to Dynamism, nothing exists in nature but centers of force, whose essence is to act. The action of one of these centers will be prevented from producing its natural effect if it is counteracted by the resistance of another force of equal and opposite value. And thus the state of equilibrium will arise and will be a mode of tension. Inertia is thus explained in this system not by the absence, but by the equilibrium of forees.

A greater defiejency of Dynamism is perhaps its incapability of explaining extension. The centers of fores it admits in nature are unextended. By being conglomerated in countless numbers, they give rive to an apparent, illusory extension, in the same way as points, placed side hy side, may lead us to believe in their forming continuous letters.

The comparion just griven, first proposed hy Boserich himself, simply ignores the diffienlty. Points placed sede by side may lead us to believe in their forming contimuous letters, provided each of them posiseses a certain extension. If the points are altogether unextended; if, as regards extension, each one is

- cf. Tait, Propertios of Matter, p. 20. 
nothing, their sum will also be nothing, and no illusion of continuous letters will be possible. This is precisely what takes place in Boscovich's system. His centers of force either are in contact with one another or they are not. If they are, they co-penetrate one another, and there is no extension. If they are not-besides the fact that the so-called heresy of distance action is then involved-we have a series of points, none of which has extension; and as each one, in so far as extension is concerned, is thus nothing; as between them there is only void space, which is equally nothing, we cannot conceive how from the union of those countless nothings a something-even as an illusion-can arise.

The atomistic theory presents likewise a large number of difficulties that baffle our powers of observation and reasoning and leave us face to face with the dreadful sight of our utter insignificance. Mere atoms in the universe of matter, we took pride in our intellectual omnipotence. We looked on the towns we had built, the rivers we had spanned, the oceans we had crossed. We saw with delight thunder and lightning yield to our caprice. We then called ourselves the kings and lords of Nature. Undeceive thyself, $\mathrm{O}$ man! thy body is but an atom and thy mind is powerless. The lowliest fact of nature is for thee a mystery, and the more thou shalt study, the more elearly shalt thou see that ignorance is thy destined lot.

Ancient Atomism admitted nothing but atoms and void space. In order to avoid the assumption of distance action, the hypothesis of a fluid called ether was subsequently introduced. A mere hypothesis at first, when invoked to explain only the phenomena of light, the theory of ether was strengthened almost indefinitely when Clerk Maxwell showed that the phenomena of the electromagnetic field can be explained by an ether identical in nature with the luminiferous medium.

The great discovery of the English scientist was still further confirmed by the experiments of Hertz, who detected the existence and measured the speed of the electro-magnetic wares, thus 
laying the foundation upon which the edifice of wireless telegraphy has recently been erected. ${ }^{30}$

There seems thus not to be the slightest doubt as to the existence of ether. But, if we alvance one step further and try to investigate its inherent constitution, we will find ourselves involved in darkness and condemned to nescience.

some physicists have regarded ether as composed of minute particles, of a sort of atoms, infinitesimal in comparison with those of ordinary matter, but still atoms. This view was held by Lard kelvin, by Whetham, ${ }^{31}$ and taken as the current ether thenry by Herbert Spencer, who gave it as a proof of the unknowable character of the reality which surrounds us in nature. ${ }^{32}$ The sime view has been defended in February, 190\%, by Mr. Véronnet, in the lérue de Philosophie. These are Mr. Véronnet's words:

"The electrieal theory ohliges us to reduce matter and its phenomena to a system of attractive and repulsive central forees, called electrons. 'These forees are obliged to act at distance, inasmuch as they are found in the atomic or granulous state. They form discontinuous eenters, and ether itself is constituted by them." ${ }^{33}$

It is rear that, as an explanation of distance aetion, ether. thus understood, simply shifts the question. If it is amposed of minute particles, these cither must be separated by absolute void, and we are thus bromght back to our starting-point, or they demand a seend ether to cxplain the first, and we must admit an infinity of similar fludds, of which each and all are absolutely valueless as an interpretation of distance action.

The opposite view, more generally maintained nowadays, is that ether is not composed of atoms separated hy void space, but is itself absolutely continuous. This conception is repeat-

so ('f. Whetham, Reent levelopment of Physical Serience, p. 270.

"Ibid., p. 292.

- Cf. Spencer, Firat P'rinciples, Pt. 1, Chap. 3, nect. 18.

s La matiere, les ions, les dectrons; Rer. de Philes., 1907, p. 156. 
edly expressed by Joseph Larmor, in his famous work: Ather and Matter:

"All that is known (or perhaps need be known) of the æther itself may be formulated as a scheme of differential equations defining the properties of a continuum in space, which it would be gratuitous to further explain by any complication of structure." 34

The same conception is also entertained by Sir Oliver Lodge, who sums up in the following words his own view on the subject:

“As far as we know, it (ether) appears to be a perfectly homogeneous incompressible continuous body, incapable of being resolved into simpler elements, or atoms; it is, in fact, continuous, not molecular." 35

Now, is this second view in any way more satisfactory than the first? Our knowledge of nature shows us that the essential difference existing between solids, liquids and gases, is due to the greater or less degree of continuity of their structural particles. In the gaseous state a molecule freely passes from one molecular system into another. A diminution of temperature lessens the vibratory motion of the molecules, which are then reduced to a definite system, and are limited in their motion by the molecules surrounding them. The result is the liquid state. A further decrease of temperature draws the molecules still nearer to one another. Each one enters the sphere of action of the others, losing thereby the possibility of translatory movement, and becoming limited to orbital motion. A material object becomes therefore more and more solid in proportion as its continuity increases. If ether be perfectly continuous, it must be incomparably more solid than any other object. That this is not the case is almost an evident truth, inasmuch as if ether were endowed with such a degree of solidity, it is inconceivable how movement in it would be possible.

"Larmor, Fther and Matter, p. 78.

${ }^{35}$ Lodge, Modern Views of Electricity, p. 396. 
Modern physicists reply to this objection by saying that we must not conceive ether as an ordinary material substance: "The properties of ather, says Sir Oliver Lodge, must be somewhat different from those of ordinary matter."36 We doubt whether this remark will seem convincing. Ether is either material, or it is not. If it is material, it must be, like matter, composed of particles-either continuous or diserete-and the laws which apply to matter in general must apply to it also. If, on the other hand, it is not material, it is inconceivable that it may act upon matter, or be a connecting-link between atoms.

Whatever may be the view we accept as to the nature of ether, we are thus facing enigmas whose solution seems to be far beyond the rach of our present knowledge and to be destined to be a puzzle to human thought for many a future generation.

Iet us not, however, conclude from these remarks that our knowledge of nature has not been increased by seience. Although the unknown still exists, positive results have been obtained, especially in these last years, to such an extent that we may seem justified in the hope that what is still mysterious for us will be revealed to the rising generation.

The first great step toward an actual knowledge of matter was made by John Dalton. He revived the hypothesis of atoms to explain the fact that the clements of a compound combine in definite proportions, and suggested that these proportions represent the relative weight of the atoms.

As the atomic weights of many elements were found to be multiples of that of hydrogen, l'rout supposed that the atom of hydrogen was the ultimate basis from which all substances were made. 'This suggestion, however, implied that the equivalents of all substancess should be integers, which was not confirmed by experience, and P'ront's view was forcibly abandoned. Such was still the situation when, in $189 \%$, J. J. 'Thomson detected, in the eathole rays of a vacuum tube, corpuscles about one thousand times smaller than the atom of hydrogen. These cor-

" Loulyer, op. cit., p. 3961. 
puscles were shown to be identical whatever might be the nature of the tube or of the gas it contained. Vast was the field opened to science by this astounding revelation. The newly-discovered corpuscles were found to be atoms of electricity, were called electrons, and recognized as the long-sought-for ultimate basis of matter, as the sub-atoms which, grouped in various ways, give rise to the chemical atoms of all material objects.

The existence of the electrons has been repeatedly evidenced by experience, and it has received a strong confirmation by the recent discovery of radio-active substances.

The first observations on radio-activity were made by Becquerel, who, in 1896, discovered that compounds of uranium affect photographic plates through an opaque covering. The labors of Mr. and Mrs. Curic, of Mr. Rutherford, and other distinguished men of science, have thrown the desired light on the subject.

It is now well known that uranium, radium, thorium, and a few other metals constantly enit three types of rays, known as the $\alpha, \beta$, and $\gamma$ rays. The $\beta$ rays have been most successfully studied, and are known to consist of negative corpuscles, or electrons, projected with the velocity of light. The a rays have been shown to consist of positively eharged bodies, projected with a velocity of about one tenth of the velocity of light. The $\gamma$ rays are the only ones whose nature is not yet fully known. The results of experience ineline us to believe that they are analogous to Röntgen rays and consist of wave-pulses traveling through ether with incredible velocity.

The study of radio-active substances has also made known the fact that not only atoms are divisible and composed of electrons. but that real changes take place in the atoms themselves, by a process of disintegration, followed by a regrouping of the electrons, and that new substances thus arise from elements chemically simple.

From uranium and thorium products have been obtained, considerably more active than those metals themselves. To these 
new substances the names of uranium- $X$ and thorium- $X$ have been given. But further observation has shown that these highly active products little by little lose their activity, and that the metals from which they were obtained regain at the same time the energy they had temporarily lost.

'These interesting phenomena have been explained by the fact that all radie-active substances have high atomic weights, are therefor of a great complexity, and thus very instable. They constantly undergo a process of disintegration of which their radio-activity is the result. One or more particles are detached from the atom, and the atomic equilibrium is thus momentarily lost. Finally, the electrons arrange themselves differently. attain a new temporary equilibrium, and give rise to the substanees known as thorium-X and uranium-X.

Yo doubt is therefore to be entertained as to the real change: that take place in the atoms themselves. And these changes hring to our minds the possible realization of the dreams of the Mrdiaral alehemists, at which, for so long a time, we have been wont to smile. If the atom is a complex structure which, on the oreurrence of rertain conditions, is disintegrable, there is nothing alsolutely impossible in the transmutation of one metal into another. 'The only question is to bring about the conditions which the atomie disintegration necessitates. Do sueh conditions exist for all rbemical elements? Wo are not inelined to beliese it, but their existene is not an impossibility. and the hope of the Mediaval alehemist was not so preposterous as we have been taught to believe.

'The facts which modern sedence may look upon as established truths are the following:

All substances, phrsically considered, are composed of mole"uler, which may he termed phregeat units, contain one or more chemieal atoms, and, by their incessant motion, give rise to heat and other physieal phenomena.

The molecules are composed of atoms, or rhemical units. which, by their regrouping in different manners, give rise to the 
various compound substances and are indivisible by chemical processes.

Finally, these atoms are nothing but groups of ultimate units, or electrons, which are the same for all substances, and, by their arrangement in different ways, form the simple elements which, until recently, had been believed ultimate.

The recent views as to the structure of the atoms, which we have briefly described, present a certain likeness to the Scholastic theory of matter and form. This theory, by means of some modifications, might even be brought into perfect harmony with these scientific results.

The modifications $I$ have in view are the following:

Let us call primordial matter the mass of electrical units, or electrons, which have been shown to be the ultimate groundwork out of which all material elements are built.

Let us call substantial form the different arrangements of these ultimate units, to which the variety of material substances is due.

Primordial Matter will thus be the same in all things. The diversity of nature of the various substances will be due to the substantial form.

Our theory will be more in harmony with the spirit of Aristotle, who, in explaining matter and form by means of brass and a statue, implies that it is a real entity, and not an abstraction, that he has in view.

All the facts upon which the Scholastic doctrine of matter and form is based will be satisfactorily explained. The stability of quantity under all modifications of bodily substances will be accounted for by the fact that the ultimate units, although arranged in different ways, are still present in the same number.

As for the hypothesis of substantial changes in chemical combinations, it must be frankly abandoned. The atom of water must not be regarded as a homogeneous substance, but as a mere juxtaposition of two atoms of hydrogen and one of oxygen. The permanence of the elements in the compound is universally 
admitted by chemists to-day. It is involved in the electron theory and has received a new confirmation from the phenomena connected with radio-activity. A study of the compounds of radio-active metals hats shown that the rate of emission of the radiations depends only on the quantity of the element present, and is not affeeted by the amount of inative substance which the compond contains. It is thus made clear that in a metallic: compound we have not a substance composed of homogeneous atoms, but that the very atoms of the simple clements are juxtaposed and form new molecules. To Farges's objection that, in the case of a mere juxtapesition, the disolvents of the simple elements should be effective, we will answer that dissolution is a physical-not a chemical-process, that dissolvents can ad only on physical units or molecules, and that the atoms which, by their juxtaposition, form these molecules, being chemical units, are separable only by chemical processes. 


\section{CHAPTER V}

\section{SCHOLASTIC PSYCHOLOGY}

\section{Section 1.-Theory of Abstraction}

Experimental Psychology is a new-born science still seeking its definite path. After numerous hesitations and partial failures, it has come to the conviction that its true aim is not to supplant the old metaphysical psychology, but to walk side by side in the most peaceable manner. Experimental psychologists know full well to-day that the worth of the results they will obtain will be inversely proportional to the metaphysical preoccupations they cherish. Wiser than their older brethren, they limit themselves to measuring on the skin of the forehead the degree of fatigue produced by an intellectual work, and abstain from all hypotheses concerning the materiality or the spirituality of the mind.

Metaphysieal psychology enjoys therefore an independent existence. It remains a branch of philosophy, whereas its younger sister is a positive science.

Scholastic psychologists adhere to Aristotle's definition of the soul: "Anima est actus primus corporis physici organici, potentia vitam habentis," regard the soul as the substantial form of the body, and maintain that it is essentially simple, spiritual and immortal.

Their proofs of the spirituality and of the immortality of the soul will find their place at the end of the present chapter. Before we expound them, it is necessary to discuss a question which may be said to lie at the very foundation of Scholastic psychology: the question of abstraction.

The theory which regards the mind as capable of abstracting from all particular determinations and of forming general ideas 
has received in modern times many severe blows. The celebrated British philosopher, George Berkeley, recards the overthrow of that theory as a necessary presupposition of his system. In the Introduction to his Principles of II uman Knowledge, he gives, in a somewhat jocose fashion, a minute account of what he understands by abstraction. He tells us, for example, that, by the abstract idea of body is meant "body without any particular shape or figure, withont covering, either of hair, or feathers, or scales, etc., nor yet naked: hair, feathers, scales and nakedness being the distinguishing properties of particular animals, and for that reason, left out of the abstract idea."' Ile thereupon confesses that he cannot, by any effort of thought, conceive the abstract idea thus described. II conclusion is that an abstract general idea is an absurdity and that the only ideas we are entitled to regard as general are particular ideas which are made to represent or stand for all other particular ideas of the same sort. ${ }^{2}$

Berkeley's rejection of abstraction rests upon a lamentable confusion which has originated in Locke and pervaded the whole body of modern philosophy: the confusion of the two terms Phantasm and Idea.

A writer who feels little sympathy for the schoolmen, John Stuart Mill, confesses that they were unrivalled in the construction of technical langrage, and that their definitions have reldom been altered but to be spoiled. ${ }^{3}$ Nowhere perhaps does his remark apply more justly than in the present ease.

A phantasm is the imaginary representation of a particular object previously perceived. It is a kind of mental picture which reproduces more or less faithfully what we have experienced in the past. Besides the power of reproduction, we possess the faculty of combining the objects of our previous experience in an infinite variety of forms. Now an imposing

'Fraser's Siclections from Berkeley, p. 13.

Ibid., p. 17.

J. S. Mill, System of Iogic, Bk. 1, chap. 2, sect. 4. 
structure we have admired during the day is present to our mind. We endeavor to reproduce it faithfully, to reconstruct one by one its minutest details. One moment has elapsed and our imagination is wandering in the most capricious fashion. Horace's monster sits triumphingly on the ruins of the monument so carefully constructed in the previous instant, and which has now crumbled to pieces and disappeared forever with the instant of time which brought it forth. The range of our imagining power is thus unlimited. Each one of our mental pictures, however, represents one single particular object. However blurred may be the image, however indefinite its features, it is always singular. I cannot form a mental picture of a triangle without giving it a definite size and shape, by which it becomes one individual, distinguishable from all other possible triangles.

It is to the phantasm thus described, and improperly called idea, that Berkeley's criticisms apply. 'That ideas of this sort cannot be abstract goes without saying. No triangle can be imagined that is not either scalene, isosceles or equilateral; no body that is not either covered or naked. But it is not an idea of this sort that the great masters of Scholasticism considered as the product of abstraction.

Besides the power of reproducing and combining our past sensations-a power we possess in common with the lower animals-there exists in us a faculty of conceiving the universal as such, of forming true ideas.

'The idea, which, to avoid all confusion, it would perhaps be better to call concept, is no mental picture whatever. It is a notion of our mind, the knowledge of what something is. We know that a triangle is a geometrical figure consisting of three sides and three angles. This knowledge is the idea of the triangle. It is elear and distinet, and is also universal, inasmuch as it applies to all triangles we may happen to conceive. It is an abstract idea, because it is not limited, like the phantasm, to one particular object, but may be truly predicated of a 
whole class. The essential characteristics which separate it from the phantasm may be reduced to the following three:

1. The idea is one. The idea of a triangle is one and the same for all possible triangles. The phantasm, on the contrary, is multiple. The imaginary picture of a right triangle is unlike that of a scalene triangle.

2. The idea is universal, inasmuch as we predicate it of all cxisting and possible ohjects of a class; the phantasm is singular and concrete, hecause it applies to a determinate object and to no other.

3. The idea is necessury and immutable. The clements of the encept of a triangle are invariably three sides and three angles. The phantasm is mutable and contingent. It changes as rapidly as the ohjects which present themselves to our senses."

The confusion we have thus deseribed may he readily arcounted for. Our intelligence eannot easily operate without its concomitant phantasm. Although a reasoning about a triangle might be effected without the help of a sensihle image. it could not be but at the cost of the most strenuous mental efforts. This is the reason why text-books on geometry exhibit sensille images side by side with the demonstrations. It is the reason why Iocke and the whole British empirical sehool have hem led to a confusion which even such a clear-minded man as Berkeley has been unahle to detect.

One of the most interesting pastimes of a scholar is the perusal of the works of the great masters of human thought with the purpose of reading hetween their lines what they themselves have not read, of dedueing from their prineiples the logical conseguenees they have not deduced. Berkeley in particular may offer us some delicious hours of entertainment. Talented as he was, he could not but reengnize that the conceptions of our minds are not copies of sensible impressions, that the illess of fiod and of the koul are not mere reproductions of the lata of sense-experience. Inwilling, however, to give up

- ('f. Cincbra, Elementos de Filonotia, Vol. 2, p. 73. 
his theory of ideas, he thought he could save his position by using the word notion:

"So far as I can see," said he, "will, soul, spirit, do not stand for different ideas, or in truth for any idea at all, but for something which is very different from ideas, and which, being an Agent, cannot be like unto, or represented by, any idea whatsoever. Though it must be owned at the same time that we have some notion of soul, spirit, and the operations of the mind, such as willing, loving, hating, inasmuch as we know or understand the meaning of these words."

We must confess that in these few lines the author of the Principles utterly overthrows the elaborate controversy of his Introduction. Iet him call his idea phantasm and his notion idea, and his agreement with us will be absolutely perfect. He has thus proved that an abstract phantasm is an impossibility, which we readily grant him. He has proved nothing against the Scholastic doctrine of abstraction, and would even probably admit with us that his notions of soul and spirit are truly general, and that they apply to all existing spirits or souls.

Closely related to the theory of phantasms and ideas, is the division of our mental faculties into organic and inorganic.

Organic faculties are those we possess in common with the lower animals. In their nature and operations, they depend upon our bodily organs. Such are the imagination and the sensitive memory. Inorganic faculties, on the other hand, depend upon the soul alone. They are essentially spiritual, and would continue to exist and to operate if our mind were separated from its bodily frame.

Upon this classification of our mental powers is based the essential distinction maintained by Scholasties between men and brutes. Iower animals possess only organic faculties. They can form phantasms, but no ideas. 'They never reach the universal because they lack intelligence, by which alone the universal is reached.

- Berkeley, op. cit., p. 53. 


\section{Sectiox 2.- Natre of the Hrmax Sorl}

Scholastic philosophers regard the soul as the substantial form of the body, from which it is intrinsically independent, though united with it in a manner characterized as substantial and personal.

By the intrinsical independence of the body is meant that the soul is an activity by itself, that it is not determined by material conditions, and hence that it will continue to exist and to exercise its operations after the death of the body.

By the substantial and personal union is meant: $(a)$ that the human compound is a substance by itself: and (b) that man is the compound, and not the soul alone. The nature of this union is very clearly expressed by St. Thomas in the following formula: "In each one of us, hy the sonl and body, is constituted a double unity, of nature and of person," "ex anima et corpore, constituitur in unoquoque nostrum duplex unitas, nature et persome."

The doctrine of intrinsical independence separates sicholastie philosephy from materialism. The doctrine of substantial and personal union sets it apart from the dualistic systems of Plato and Descartes, which regards man as a spirit accidentally united with the body, and governing it as the pilot governs his vessel.

The human soul is further described as possessing the three tharacteristics of simplicity, spirituality and immortality.

'The proofs of the simplieity of the human soul may be condensed in the following form: The nature of a being is known from its operations. The operations of the soul are essentially rimple. Hrence the soul itself is ly nature essentially simple.

Examples of simple operations of the soul may be adduced and multiplied at will. There are the simple ideas of being, truth, virtue and the like, which cannot, hy any effort of thenght, he conceived as divisible. There are the intellectual acts of judgment, which presuppoes a simple subjoct and ean hardly twe explained in any other hypothesis. If the mind

-Thomas Aquinar, Summa Theol., P. 3, q. 2, art. 1, ad 2. 
which apprehends the subject and the predicate is not one and indivisible, we have no judgment whatever, but merely two different impressions without any possible connection. Kant was perfectly aware of this truth when he formulated at the basis of his philosophy the principle that experience by itself furnishes only detached and unconnected facts, and that no judgment is possible without a mental synthesis.

The doctrine of the simplicity of the soul has been attacked by David Hume in a most ingenious manner. He describes it as a true atheism, capable of justifying all those sentiments for which Spinoza is "so universally infamous."

"There are in my experience," says he, "two different systems of being, to which I suppose myself under a necessity of assigning some substance, or ground of inhesion. I observe first the universe of objects or of body: the sun, moon and stars; the earth, seas, plants, animals, men, ships, houses, and other productions either of art or nature. Here Spinoza appears, and tells me that these are only modifications; and that the subject, in which they inhere, is simple, incompounded, and indivisible. After this I consider the other system of beings, viz., the universe of thought, or my impressions and ideas. There I observe another sun, moon and stars; an earth, and seas, covered and inhabited by plants and animals; towns, houses, mountains, rivers; and in short everything I can discover or conceive in the first system. Upon my enquiry concerning these, Theologians present themselves, and tell me, that these are also modifications, and modifications of one simple, uncompounded, and indivisible substance. Immediately upon which I am deafened with the noise of a hundred voices, that treat the first hypothesis with detestation and scorn, and the second, with applause and veneration. I turn my attention to these hypotheses to see what may be the reason of so great a partiality, and find that they have the same fault of being unintelligible, and that as far as we can understand them, they are so nuch alike. that it is impossible to discover any absurdity in one, which is not common to both of them. We have no idea of any quality in an object, which does not agree to, and may not represent a quality in an impression; and that because all our ideas are derived from our impressions. We can never, therefore, find any repug- 
nance betwixt an extended ohject as a modifieation, and a single uneompounded esenee, as its substance. unless that repugnance takes place eyually betwixt the perception or impression of that extended object, and the same uncompounded essence. Fvery idea of a quality in an object passes through an impression; and therefore every perceivable relation, whether of connexion or repugnance, must be common both to objects and impressions."

The ohjection so clearly exposed by Hume, and which, from his own point of view. seems unanswerable, loses much of its force if we bear in mind the distinction pointed out above between ideas and phantasms. The phantasm, being a copy of a previous impression, is no doubt composed of parts, just as woll as the impression is. If I picture in my mind the frontispiece of Columbia Lniversity, ten different columns stand there before me, the length of each of which may be divided into two parts; and these may again be subdivided at least as easily as the real columns could be. I believe everybody would anree with Iume on this point: but such are not the operations from which the simplicity of the soul is deduced. The sun, moon and stars Inme deseribes as existing in his universe of thought are as truly multiple as those of the universe of nature. The rivers he imagines are made of drops of water. the trees of branches and leaves. But the conclusion to which he is lod hy these considerations, his comvietion that the soul is not simple. but divisible like the miverse of matter; is that enviction divisible also? ('an it he mentally cut into two parts, two halfconvictions: or similar to the river, is it made up of an infinite number of dropes of convietion? These are, however, the absurdities from which we cannot cacape if we are unwilling to admit the essentially simple charateter of intelleretual ideas.

A great number of concepts, it is true, are in a certain sense divisible. I pon their divisibility is based the Soholastie division of coneepts into simple and complex. (omplex eonrepts are matre up of several simple elements. The coneept of

'Hume. Treatiur on Human Nature, Sellỵ Bigge's ed., pl. 242-243. 
man, for example, may be resolved into the elements of animal and rational. This sort of division is, however, quite different from that of material beings, or of their reproduction in our mind. The red surface I see or imagine may be divided into two red surfaces, identical in nature with the first, and differing from it only in quantity. The elements of the concept of man are of an entirely diverse order. They are not merely two halves of a whole. They differ from each other and from the whole in quality, and the entire process of division rests upon their specific differences. But as qualitative division cannot, like quantitative division, be continued ad infinitum, we must finally arrive at essentially simple concepts, and conclude that they are produced by an essentially simple being.

The questions of the simplicity and of the spirituality of the soul, although closely connected, must be carefully distinguished. Every spiritual being is simple; but a simple being is not necessarily spiritual. Scholastic text-books give as an instance of a simple, non-spiritual being the soul of the lower animals, which depends upon the body in all its operations, comes into existence with the body, and ceases to be as soon as the body dies.

The spirituality of the human soul may be defined as its intrinsical independence of matter. In virtue of that independence, it is not affected by the death of our organism, it does not disappear with our last breath. When this mortal life of ours comes to an end, our spirit springs forth; and, free from material bonds, starts a new and purer life, a life that shall know no death.

The spirituality of the soul is proved from the nature of its faculties: the intelligence and the will. These faculties have for objects the universal and the necessary. It is to the universal as such, to a nature conceived with an absolute-not an individual-character, that our intelligence tends. It studies the essence of the object, abstracting from the indivilual characteristics of "this" object. A peculiar aspect of 
the universal is its neeessity. This necessity, human intelligrence does not fail to grasp. It directs its efforts to the immutable aspects of things, and abstracts from the contingent character they possess as individuals.

Our will likewise temels to the universal manifested in the form of the alsolute grood. No limited and relative grood an satisfy us. It is in the union with an absolute perferetion that out will would rest, that it would find its perfect happliness.

low, these characters of universality and necessity unexpivocally separate our mental faculties from the pure forees of matter. Matter is essentially individual, and envelops in individual conditions all objects of which it is an essential constituent. Our mental faculties are thus independent of matter. and the soul, the substance they constitute. is necisarily andowed with the same independence. ${ }^{8}$

Several other arguments of lesser importance are addued to confirm the same view. The act of self-conscionsness, for example, is said to separate the soul from all material agents: for. whereas matter can act upon itself only in the sense that a certain particle can act upon another particle, the human mind can and does reflect upon itself in such a manner that the Ego reflecting and the Egro reflected upon are one and the same."

A third proof very much insisted upon is dedued from the contrast between the effects produced upon the intellect and the senses by their respective ohjects. When the excellence of the object of sense increases begond a certain limit, the organ undergoes corruption, and is eventually destroyed. A vivid light impairs our eye-sight; a prolonged contemplation of the sun may result in blindness. Our intellect, on the contrary, becomes keener and more penetratinger when the object it ponders becomes more sublime.

The characteristics which separate sense from intellect are reduced by I rraburu to the following six:

"Cf. Carlair, la Nature Humaion, pp. l69 fr.

Maher, Pyychology, 3d ed., pp. 452 tr. 
1. (Which is essential and the root of the others.) Intellect is an inorganic or spiritual faculty; sense is organic and material.

2. Sense is found in all animals; intellect only in rational animals or men.

3. Sense knows only the singular; intellect knows the universal.

4. Sense extends only to material objects; intellect to immaterial objects as well.

5. No sense knows itself or its own operation; the intellect knows itself and its operation.

6. The senses are corrupted by the excellence of the sensible object; the intellect remains uncorrupted, however excellent its object may be. ${ }^{10}$

The remaining property of the soul, its immortality, follows from the previous two as a logical consequence. The soul, being essentially simple, cannot, like the body, perish by dissolution of parts; and, on the other hand, being spiritual, having its peculiar, independent life, not being conditioned in its existence and operations by the bodily organism, it cannot cease to exist simply because the organism is destroyed. The theological belief in another life is thus not only shown to harmonize with reason, but is deduced from the fundamental principles of philosophy. Whether human reason can likewise prove the eternity of this new life, is considered a debatable question. Maher, in his Psychology, answers it negatively. As a theologian, he believes in eternal life; as a philosopher, although he sees no reason why the soul should ever perish, he admits that "leaving Revelation aside and arguing solely from reason, he does not see any perfeetly demonstrable proof of the everlasting existence of human souls." "Almighty God," adds he, "could. hy an exercise of His absolute power, annihilate the human soul as well as any other object which He has created."11

${ }^{10}$ Cf. Urraburu, Compendium Philosophia Scholastice, Vol. 4, p. 240.

"Maher, op. cit., p. 486. The same view is also maintained by Meurin, Ethies, p. 161. 
I believe that most neo-Scholastic's would disagree with Fr. Maher on this point. They would be inclined to maintain that the hmman soul can he proved, not only to endure for a certain time after death, hut to endure forever. This view is clearly exposed and defended in the works of Crraburu. Starting from the ordinary arguments of the school, the learned Jesuit demonstrates that the soul cannot perish like the body hy a natural death. and he reaches Maher's conclusion that the soul can cease to exist only through an act of annihilation of an all-powerful (iod. But, whereas Maher stops at this point. and leaves human reason uncertain whether ciod will destroy or not the spirit he has created, l'rrahuru show: that such an annihilation would involve an inconsistency in God's own nature. His argument may be outlined as follows: God has constituted the human soul in such a way that it is naturally immortal. If he should ehoose to destroy it by an act of his will, there would be a contradiction between the ereative act by which he gave the soul an immortal nature and the destructive fiat which would reduce it to nothingness. As no such contradiction can be supposed in an absolutely perfect leing, the soul will exist forever. Irraburu corroborates his teaching by the authority of Sit. Thomas. The annihilation of the soul would he a miralele, and a miracle never takes place exeept as a manifrstation of Ciod's glory. But, St. Thomas says, " redigere aliquid in nihilum non pertinet ad gratue manifestationem. cum magis per hor divina potentiue el bonitas ostemdatur. qued res in esse conseretur."

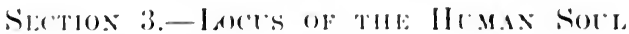

The title of this seetion sughests a renerable formula, frequently derided nowadlays and more frepuenty misunderstoed, the famous Tota in toto. ot tota in qualibet parte, which has been recently promounced "disconorting hut to the chosen frew who

12 Thomas Aquinas, summa Theol. P. 1, Q. 104, art. 4, e. ('f. I'rrat burn, op. cit.e ple tiotitr. 
have embraced a philosophy of contradictions, and rejoice in the absurdity of the conclusions to which their reasonings conduct them."

The words I have just quoted are from Mr. Fullerton. In a chapter of his System of Metaphysics, entitled "The Atomic Sclf," he exposes the semi-materialistic opinion of the plain man about mind, and traces it back to the philosophies of the most ancient times. He holds that the teachings of those old systems have become incorporated into theology and ethics, have left their traces upon language and literature, have become a part of the common thought of the human race, and are now accepted by the great mass of men as self-crident truths.

"Ancient philosophers believed the mind to be material and unequivocally in the body. It was composed of fine round atoms, highly movable atoms, etc. It could be inhaled and exhaled, and might escape through a gaping wound, as wine spouts through the rent wine-skin. It was a kind of matter and nothing more, having the same right to occupy space that has any other form of matter. Afterward it was for centuries still in the body, but in a much more indefinite and inconsistent fashion. It was wholly in the whole body, and wholly in every part." 13

The Scholastic formula is thus regarded by Fullerton as the direct offspring of old materialism. It is materialism still, although somewhat transfigured. It is materialism aware of its inner incongruity, and trying to save its own life by means of vague subterfuges. The mind is still located in the body, but its presence there is regarded as immaterial. Descartes who emphasized the presence, but neglected its immaterial character. located the soul in the pineal gland. The scholastics emphasize both sides of the inconsistent doctrine. They "stir up the contradiction and make it growl, striking fear to the heart of the beholder."

Fullerton's doctrine on the locus of the soul is identical with Hume's. Although we differ from the author of the Treatise

${ }^{13}$ (A. S. Fullerton, System of Metaphysics, p. 267. 
on Iuman Nature in many essential points, we cannot but fully agree with him here, and even regard his teaching as irrefutable. Location in a determinate place is a property of material beings, and has no sense except if applied to such. The ehair upon which I am sitting is said to be located between the walls of my room in so far as it can grive rise to tactual and visual impressions spatially related to the impressions eaused by the walls themselves. When we assert that the point $A$ is between $B$ and (', we mean that a line going from $B$ to $('$ would pass through $A$. Location in space, thus applied to material beings, is perfectly intelligrible; but, as Ilume and Fullerton maintain, it loses all meaning if predicated of mind. It sounds nonsensical to assert that a thought is placed between a desk and a blackboard, that ten different wolitions are actually crossing the street; but if we express the same idea in different words. if we say that the human mind is placed in a certain portion of our organism or in our whole body. the absurdity of the assertion becomes less apparent and maly be easily overlooked. It exists, nevertholess, and to say that our mind is loeated in our body, or that ciod is located everywhere-if we take the word located in its proper meaning-is no less preposterous than to say that a benevolent desire took the forry-boat. and was slowly earried from New York to Brooklyn.

Where is our mind then?" And where is ciod? Such questions cannot be answered but in the following way: Our mind is nowhere, and fool is nowhere. The "where" implying parts outside of parts, and being a property of matter alone, cannot be predicated of immaterial things. And if it sommls oxh to say that sperits are nowhere. it is hecaluse wo are so immersed in material thinking that we cannot heliese that a thing can exist without material relations. The existence of our mind is

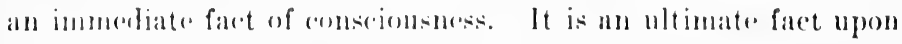
which all our knowledger is grounded, and which itself noeds no prosef. It is the center from which we have to start in our investigations concerning reality. But the relations which our 
mind bears to the rest of the universe cannot be assimilated to the relations of particles of matter. We fully agree with Hume and Fullerton that a philosophical system tending to localize mind in a definite portion of space must be rejected as absurd.

What becomes of the Scholastic formula then? Must we, without more ado, regard it as the outcome of an illogical materialistic conception of an immaterial thing? Some powerful motives at once come forth and give to this view the greatest uncertainty. St. Thomas's doctrine of the soul, inspired by Christian theology, is more decidedly immaterialistic than the theories of Locke, Hume, and the whole British empirical school. For whereas sensism resolves ideas into sense-impressions and admits only a difference of degree between sense and intellect, St. Thomas and the schoolmen maintain that the difference is not of degree but of kind, that between the sensuous impression and the intellectual thought there is an impassable chasm. How strange would it sound then that he who might be deseribed as the foremost adversary of materialism, should himself fall into the very errors he constantly opposes!

A careful study of the doctrines of St. Thomas suffices to absolve him from all charges of materialism. The Angelic Doctor not only did not intend to localize the mind in a definite portion of space, but he was as fully aware as Hume of the evident truth that position in space is a property of matter and of matter alone.

In the Summa contra Gentiles, St. Thomas examines how an intellectual substance can be united to the body, and teaches that there are two kinds of contact: a contact through quantity, which is proper to material beings alone, and a contact through virtue, which may belong to immaterial beings as well. This latter kind is however described as contact only metaphorically. A spirit is said to touch only in so far as it aets, only in the sense in which we are entitled to say that a sad news touches us:

"Si igitur sint aliqua tangentia qua in quantitatis nltimis 
non tangant, dicentur nihilominus tangere, in quantum agunt: secundum quem modum dicimus, quod contristans nos tangit."

Further on, the Christian teaching of God's ubiquity compels st. Thomas to take up the same question again. And now as before, his teaching is unmistatiably elear:

"Iies autem incorporea in aliquo esse dicitur secundum contactum virtutis. quum careat dimensiva quantitate. Sic igitur se habet res incorporea ad hoe quod sit in aliquo per virtutem suam. sicut se habet res corporea ad hoe quod sit in aliguo per quantitatem dimensivam. Si autem esset aliquod corpus habens quantitatem dimensivam infinitam. oporteret illud esse ubique. Ergo, si sit aliqua res incorporea hahens virtutem infinitam. oportet quod sit ubique. Est igitur ubique."

We thus see that. in St. Thomass riew, the words: fod is everywhere, simply mean that he acts upon all beingrs. We also see that the presener of the soul in the body must not be regarded as a material presence. It is not in the bedy as the hood is in our reins. Properly speaking, it is not in the loody at all. It simply acts upon the body, and touches it as a precer of bad news touches our beart. The formula: Tota in toto et tota in alique parte, thus understood, loses all its material flavor. Instead of appearing as a nonsensical collection of words, wortly of derision and seorn, it steps forth as a flash of genius, as a profound truth which commands our admiration and our assent.

"Thomas Aquinas, Summa contra Gentiles, Lib. 2, chap. 56.

is Ibid., Lib. 3, cap. 68. 


\section{CHAPTER VI}

\section{SCHOLASTIC NATURAL THEOLOGY}

\section{Section 1.-Natural and Revealed Theology}

The very title, Natural Theology, suggests that some other kind of theology exists. And, indeed, Scholastics have always carefully distinguished between natural and revealed theology. This is one of the points which unmistakably separate the Scholastic system from the philosophy of the Hegelian school. According to Hegel and his disciples, no truth lies beyond the reach of the human mind. God is an object of experience as clearly present to our natural faculties as tables and chairs. An adequate knowledge of the Absolute is thus perfectly possible, and theology becomes a branch of philosophy.

St. 'Thomas and the Scholastics, on the other hand, believe that the Divine Essence cannot be known by our finite minds. Our natural faculties may lead us to the knowledge of God's existence; they may even enable us to reach a true knowledge of his nature; but, as this knowledge is not reached by direct intuition, but by the consideration of the finite world in which we live, it cannot be adequate.

As the imperfect knowledge of God our mind can attain may be supplemented by the Divine Revelation, the science of theology is evidently twofold: Natural Theology deals with the knowledge of God human reason can attain by its natural forces; Revealed 'Theology deals with the knowledge of God which lies beyond the reach of our natural faculties and is attainable only by revelation. The philosopher is thus concerned with natural theology; he has nothing to do with revealed theology. 


\section{Section 2.-Proofs of Gods Existexce}

All possible proofs of the existence of the Divine Mind may be classified under three heads:

1. The a priori proof, derived from the very concept of (iod, and usually known as ontological argument.

2. The a posteriori proofs, by which we ascend from the knowledge of the finite world to the knowledge of the infinite.

3. The moral arguments, drawn from the nature and aspirations of the human heart; also, from the common consent of mankind.

The ontological argument has never enjoyed much favor among Scholastic philosophers. First proposed by Anselm of Canterbury and at once assailed by caunilo the monk, it has been discussed and finally rejected by Thomas Aquinas. Accepted in a slightly modified form by Descartes and Ieibniz, it has been rejected again by Kant and readmitted by Hegel, who believed that since its first formulation until the time of Kant it had been unanimously accepted among philosophers.'

These repeated attempts to rehabilitate the fallen argument have been a decided failure. Neo-sicholastics to-day regard the ontological proof as worthless, and, in so doing, are perfectly justified. The weak point of the argument has been elearly pointed out by Thomas Aquinas." Anselm's reasoning unduly passes from the ideal to the real order. The conception of the most perfect being must include the element of existence, as Anselm believed ; but this existence must be ideal, limited to the coneept of our mind, and cannot legitimately be predicated of the objective world.

The argument from the moral law has been repeatedly formulated and defended. All men, it has been said, believe in the existence of a moral law. They all regard some actions as praisworthy, others as condemnable. Now, without God, a

' ('f. Hegel, Hintory of Philosophy, Pl. 62 nol 64.

'Thomns Aquinas, Summa Theol., P. I, Q. 2, urt. 1; C. (i., I.ib. I, cap. 11 . 
moral law would be an absurdity, because the very notion of a law implies the existence of a legislator, endowed with a sufficient authority to impose it and give it a sanction.

Is this line of reasoning defensible? We are not inclined to believe it. The fact that some acts are universally praised as good, while others are universally condemned, may be sufficiently explained from the nature of the acts themselves without any necessity of a recourse to a supreme Lawgiver. There is no doubt that if God exists, he is the foundation and the source of all truth, and therefore the ultimate ground of the moral law; but, as his existence is precisely in question, it is from the human acts themselves that we must start. As no mathematician needs to postulate a Divine Being in order to understand that the sum of the angles of a triangle has been universally believed to be equal to two right angles, so the moralist needs no God to account for the fact that ineontinence is universally regarded as degrading and courage as praiseworthy. The very results of our acts give us the elue as to their moral character. Scholastic philosophers are thus right when they refuse to assign to the argument from the moral law a primary importance.

Another moral argument, altogether different from the one we have presently considered, is derived from the common consent of mankind. Like all moral arguments, the argument from universal consent is regarded by Scholastics as of secondary importance. It is, however, defended as legitimate, and invariably finds a place in treatises on natural theology. The fact itself that all peoples have believed in a Supreme Being seems to admit of no reasonable doubt. To Spencer's objection that the savage's concepts of God have been evolved out of ghosts or ancestor-spirits, and, with the evolution of human ideas, have gradually acquired a nobler form, Scholastics answer that the conceptions of God found among savage or semi-civilized nations are corruptions of a purer and older form, and that the tendency of mankind is thus to fall away from a primitive 
monotheism. Whether this theory can be maintained nowadays, I will not here discuss. I will limit myself to remarking that it is far from rendering the argument from universal eonsent unassalable. This argument even becomes valueless if we take into aceount the fact, attested by the Biblical relation and generally admited to-day by natural seience, that all men have come from as single stem. The force of the arrument lies in the fact that a notion of the Deity is found among all tribes of men, and must thus be due to human nature itself, inasmuch as an error or a fraud might have erept among one particular nation, but conld not posesss a universal character. Now if all men had a common origin, if there was at the beginning a single family, it may be perfectly well supposed that an erroneous notion has been accepted by this family, and, tranimitted to itposterity, has beenme a universal error of the human race.

The arguments we have described as a pesteriori are reperially insisted upon hy st. Thomas and his modern followers. These arguments invariably start from the knowledge of the world given in experience, and rise to the knowledge of ciod. They assume different forms, which may he reduced to the two we shall presently expose.

The first is sometimes deseribed as " physical argument." It starts frem the croler of the world, the perfect adaptation of means to conds which we find around us, and concludes that such an anlaptation evidently points to the existenes of a supreme De-igner. Abrolutely speaking, a castual shock of atoms might inderd have produeed the world surh as it is, just as printing haracters, thrown at random, might give the play of IIamlet, but the chanee for such a probluction is an insignificant that it

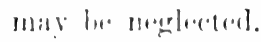

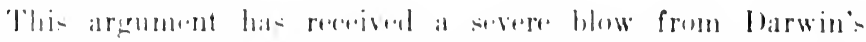
lenery of natural selection. It is asen contended that it has been ab-ellutely killed. It is morally imposible that the paw of the cat, $\therefore$ ferfectly adapted to the catching of the prey.

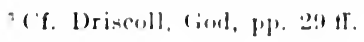


should have been produced by a casual shock of atoms, just as it is morally impossible that printing types, thrown at random, should give the play of Hamlet. But, if we adopt the theory of natural selection; if we admit that the types which happen to fall in the definite place they have in the play shall persist in existence while the others shall disappear, the play of Hamlet will fatally be produced.

We should be cautions, however, not to assert too hastily that the argument from design has been absolutely killed. The hypothesis of natural selection explains the order of the world without taking a supreme Designer into account. But what of natural selection itself? How are we to explain the tendency of the atoms towards definite arrangements, the fact that some arrangements persist in existence while others are destroyed? Instead of the innate tendency of the atoms towards definite groups, why was there not a tendeney towards a perpetual chaos? A chaotic cosmos seems indeed the only possible outcome of a mere shock of atoms, and the hypothesis of natural selection is a nonsense if we do not admit finality. All the perfections of the future world must thus be supposed to exist potentially in the originary ehaos, and the necessity of a designer by no means disappears.

The metaphysical argument is based upon the principle of causality. The fact that no beginning of existence can happen without a cause has been proved in our chapter on metaphysics and needs not be insisted upon. In the metaphysical argument, the form of the principle of causality is somewhat modified. "Whatever does not exist of absolute necessity, it is contended, "annot exist withont a proportionate cause."4 Which means that the cause, ensidered in its totality, must contain a perfection at least equal to that of the effect. The validity of this form of the principle of causality might perhaps be questioned. It is strongly defended by neo-Scholastics, who contend that if the cause failed to be proportionate, the excess of the effect

- Boedder, Natural Theology, p. 33. 
would really lo without caure, and the general law of causality would be therehy violated."

The massity of a proportionate cause being admitted, the existence of a siupreme Mind follows as a neersiary eomsequence. A rear ideat of the Sicholastic lime of reasoning maty be gathered from the following three propositions in which the argument may ho summod mp:

1. There are changes in our uorld, and these changes presuplest a cause. 'The truth of this first proposition has heen "harly shown in our chapter on metaphysics.

$\therefore$ These changes presuppose a self-existing cause. If the aluse of the changes is not self-existing, it must he callsol hy -omething else. 'This something else, if not self-existing, must also be caused, and we must finally arrive at a self-existing being: otherwise we would have an infinite process, and no change would he possible, inasmuch as a suffiedent cause of the rhange could never lo found. Thus far there is nothing in our arerument which a materialist would fail to admit. I salfexisting being exists, he would sily, hut we need not go begond the molecule, the atom, the material world. 'The following proposition separates the seholastic system from all materialistic hypothesis:

3. This self-existing being must be an immaterial and free being. 'The ultimate anuse of the world must not simply be a canse: it must be a propurtionate eatuse. The world contains immaterial and frese loines, sueh as the human soul. Therefore the cause of the world mut he an immaterial and free being, that is to say, a jer-onal liod.

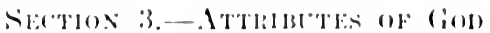

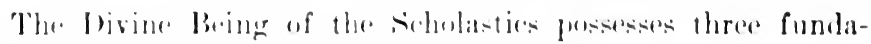
mental attributes: he is infinite, ome and simple.

Tha doctrime of an infinitw fiod is not without diffeulty. some catholic philusephers has thought that, although faith

: Ibid., p. 34. 
obliges us to believe in the infinity of the Supreme Being, this infinity cannot strictly be proved by reason alone. In a recent article of the Revue de Philosophie (1906), Mr. Dessoulavy expressed his sympathy for Schiller's thesis on this subject. The modern followers of St. Thomas, however, strongly insist upon the capacity of philosophy to reach a knowledge of the infinity of God. They adopt the line of reasoning which led Aristotle and Thomas Aquinas to the concept of pure actuality (actus purus).

Every finite being, they argue, consists of actuality and potency: of actuality in so far as it possesses some perfections; of potency, in so far as it is capable of acquiring the perfections it does not possess. Now the actual is logically anterior to the potential, because a potential bcing cannot become actual unless it be acted upon by an actual being. The ultimate cause of reality must not therefore contain any potentiality; otherwise it would presuppose another cause and would not be ultimate. It must be pure actuality, and accordingly possess all perfections in an infinite degree. ${ }^{6}$

From the infinity of God follows his unity as a logical consequence. If there were several Gods, they should differ in some characteristics. Each of them would thus lack the peculiar perfections which characterize the others, and none could be infinite. ${ }^{7}$

The proof of God's simplicity rests upon his self-existence. Whatever is compound depends upon its constituent elements and upon the cause of their union. As God is the ultimate ground of all reality, he cannot depend upon anything else and must be absolutely simple. ${ }^{8}$

From these three fundamental attributes, all attributes of the

- Cf. Thomas Aquinas, C. G., lib. 1, cap. 16; also Garrigou-Lagrange, Le Dieu fini du Pragmatisme, Rev. des sci. philos. et thcol., 1907, pp. 252 ff.

'Cf. Thomas Aquinas, Summa Theol., P. 1, Q. 11, art. 3.

${ }^{s}$ Cf. Thomas Aquinas, Summa Theol., P. 1, Q. 3, art. 7; Boedder, Natural Theology, p. 93. 
Divine Being are derived. They are not all, however, established in the same way. As our intuitive knowledge is limited to finite beings, it is from these finite beings that we must rise to a conception of the infinite. Now the attributes of creatures are of several orders: some involve imperfection, others to not. The attributes which involve imperfection, such as extension, reason, etc. cannot be predicated of God who is infinitely perfect. Those which involve no imperfection, such as intelligence, power, etc., are properly in God. But whereas finite beings possess these attributes in a limited degree, God, in virtue of his intinity, posisis them as boundless and infinite.

The attributes of the Supreme Being may be therefore classifeed into negative and positive.

The negittive attributes are immutability, eternity and immensity. They (l) not give us any real knowledge of God. They simply remose from the conception of the Infinite some imperfections attached to finite things. They do not show us what fod is, but what he is not.

God's immutability is clesely connected with his infinity. Whatever admits of change is not infinitely perfect. It lacks at some moment of its existence the perfections it subsequently acquires. It posiceses some potentiality and is not, like the Divine Being, absolutely actual.

God's eternity can be proved in a similar way. When the Scholasties astert that liod is ceternal, they do not, ats is sometimes supposed, simply mean that he had no beginning and shall know no end they al:o remore from his conception the element of sucersion. They mean that there exists for him no past and no future; that his heing is a perennial present.

Whe hase alrealy touched upon the question of ciont's immensity in wur chapter on I'stehelogy. Wo have shown that, in St. Thomas"s view, the ascertion that " God is evrywhere" does not man that he is present in all parts of space as bodies are. It mean- that he acts upon all things; that he is present in them ly a contact of virtme, not by a contact of quantity. 
The positive attributes of the Divine Being are his knowledge, his will, and his omnipotence.

God has a comprehensive knowledge of his essence, and in his own essence he sees the essences of all real and possible things. His knowldge extends to the contingent as well as to the necessary; and, inasmuch as he is eternal, to the future as well as to the past.

The faculty of will consisting in the love of the object presented by the intellect as good, involves no imperfection and must be found in the Supreme Being. God loves his own essence necessarily, because his essence is the supreme and infinite good, and is therefore worthy of an infinite love. His love for creatures is an outcome of the love he bears to himself. It is in his own essence that he knows all finite beings, of which his essence is the prototype. It is in his own essence that he loves all finite beings, the perfections and the goodness of which are found in his essence in an infinite degree.

God is also omnipotent. He can do by a single act of will whatever is not intrinsically impossible. As for things whose concept involves a contradiction-such as a square circle, or a man being an ass-it is only an improper use of the terms that leads us to assert that God cannot do them: it would be more correct to say that the things themselves cannot be done. They involve a contradiction, and the Infinite Being must above all be self-consistent. It is the same self-consistency that explains how God cannot possibly commit sinful acts. The essence of sin consisting, not precisely in the production of an effect, but in the opposition of our free will to the eternal law of God, its presence in the Divine Being would involve the denial of his own self.

The preceding classification of the attributes of God should not, however, lead us to believe that the Divine Essence is considered by Thomists as divided into separate and unconnected compartments. Hegel's reproach against the old Metaphysics, 


\section{5}

of cutting off from their connection the terms of thought," is

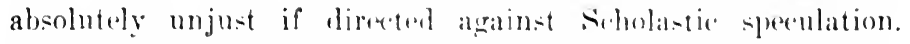
St. Thomas and his followers insist upon the physical and meta-

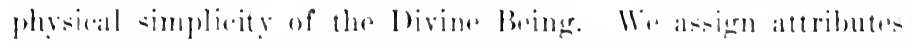
to ciod, it is true: hut we must not foreret that these atiribure.

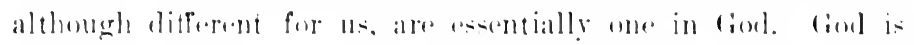
his esence or his nature:" his estence is his own herngen hiintellect his own lwing:"2 his will is also his own heingr. If we ale empelled to smely his attributes separately, it is an

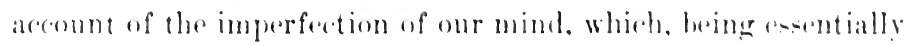
finite. cammot gratsp the Infinite: "Balbutiendo, ut fossumus.

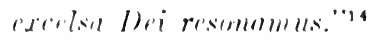

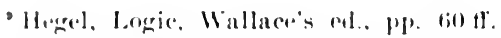

"Thomas A Apunats, summat Theol.. P. 1. (Q. 3. art. :3.

"Ilicl., l'. 1, Q. 3, art. 4.

: Ibid., I'. 1, Q. 14, art. 4.

"Ibid., P. 1, (2. 19, art. 1.

"Ibid., P. 1, (2. 4, art. 1, adl 1. 


\section{CHAPTER VII}

\section{SCHOLASTIC MORAL PHILOSOPHY}

According to Mr. De Wulf, the essential characteristics of the Scholastic system of ethics may be reduced to two heads: it is eudemonistic and libertarian.

In order to form a clear conception of the nature of this eudemonism, a few considerations about the necessary conditions underlying the activity of all beings will not be out of place here.

Waiving all other considerations, it must be admitted that all agents act for a definite end. This is true not only of conscious beings, but likewise of inanimate objects. It follows as a necessary consequence from the fact that our cosmos presents us with distinct individuals, each of which is endowed with a peculiar nature. When dynamite blows up an edifice, it acts towards an end as well as the acorn when it becomes an oak. Like the acorn, it possesses an essential character, definite potentialities which, under proper conditions, will forcibly become actual. The only difference that exists between the potentiality of the inorganic and of the organic world lies in the fact that inorganic agents do not possess any principle of self-actuation, and therefore they do not act except when moved by some external cause. Organic beings, on the other hand, are endowed with an inner principle of self-determination. It is in this very principle that the essence of life consists: "The living being," says St. Thomas, "is the one that can move itself," "Vita est substantia cui convenit secundum naturam suam movere seipsam."1

Plants, however, although self-determined, are not conscious of the end toward which their own nature compels them to tend.

${ }^{1}$ 'Thomas Aquinas, Summa Theol., P. 1, Q. 18, art. 2, c. 
They are thus inferior to sentint beings, whose esential characteristic is a more or lest clear conscinumess of their own peculiur activities. Man alene possesses an intellectual knowledge of his end, beause he is the only being endowed with reason and calpable of forming universal concepts. He alone properly knows his end and can adopt the most sultable means to reach it. He alone is a moral being.

Ends may be divided into proximate and ultimate. Proximate ents are those that are not desired for themselves; but only in so far as they are steps towards the attaining of ultimate ends. Strictly speaking, they are not ends, but means. I'ltimate ends are desired for their own sake and therefore they are not subservent to anything alse. If we consider health ats the ultimate end a sick man has in view-an mel which cannot be ultimate for him in so far as he is a man, hut only in so far as he is a sick man-the acquiring of the remedies which he is obligred to take in order to eret rid of his dienase will be a proximatre ent.

Proximate ends heing thes properly means, an infinite series of such and becomes absurd, and we mus almit that rational heings not only alet for an end, but for an ultimate and.

The great question of morality consists therefore in the determination of the ultimate end of man. All actions subservient to this and will be grond; all aetions inconsistent with this end will be bad. Now, if this world of ours is rational, we must admit that the end of all beinge is true to their nature. It can. not be but the artualization of the pertentialitie they contain, the unfolding of the latent purfortions which constitute their very isimen.

This met impertant anth has hen relegatent to oblivion he all that fut the foumdation of morality on al mere external principle.

Whather we hild our whical setrm upon the common consent of mankind, als Siant-Lambert did, or upon the civil law. as Hoblece or upm the will of lied, as ('rusius, we remere 
rationality from our world, and, by so doing, we destroy morality itself. All external systems of ethics imply that no action is good or bad in itself; that an act we now regard as good would be had if some determinate free agent had willed it so; might become bad this very day if the will or the caprice of the lawgiver should vary. Under such eonditions no science of ethics is possible.

The end of man is thus the complete actualization of his nature-or to use a term current in ancient Greece-perfect. happiness.

Here Scholastic ethics meets a powerful adversary which, under a variety of forms, has controlled modern thought, has assumed different garbs according to the varying circumstances, and, repeatedly unmasked, has appeared again and again, its appearance being the signal for prolonged applause; a system which, under the specious names of hedonism, Epieurianism, utilitarianism, is to-day perhaps more vigorous than ever and prides itself upon its able defenders and legions of adherents.

The difference between hedonism and Scholasticism lies in this: Hedonism inculeates that pleasure is the ultimate criterion of morality, and that an action is good only in so far as it is pleasurable; whereas for Scholasticism goodness lies in the nature of the act itself, and pleasure is simply an effect which may follow from a moral act, which will necessarily accompany the good in the long run, but which is not the goorl.

As hedonists often allege the authority of Plato and Aristotle in support of their theory, it will be worth while, before exposing the prime defect of Hedonism, to quote a few passages which clearly show that Plato and Aristotle did not enfuse the pleasurable with the good, and that furthermore they held, in regard to the final end of man, the very belief: that characterize the ethical system of the Scholastics.

The first passage is taken from Platos Gorgias:

"Listen to me, then, while I recapitulate the argument: Is the pleasant the same as the good? Not the same. Callicles 
and $I$ are agreed about that. And is the pleasant to be pursued for the sake of the goot? or the groot for the sake of the pleasant? The pleasint is to be pursued for the sike of the grooul. And that is the pleasiant at the presence of which we are pleased, and that is grood at the presenee of which we are good: To be sure. And we are good, and all good things whaterer are good when some virtere is present in them? That, ('allieles, is my conviction. But the virtue of each thing whether hedy or soul. instrument or creature, when griven to them in the hest way, comes to them not hy (hamere hut as the result of the order and truth and art which are imparted to them. Am I not right: I mantain that I am. . . And is not the soul which has an order of her own better than that which has no order of her own! Cortainly. And the soml which has an order is orderly? Of course. And that which is orderly is temperate? Asturedly. And the temperate soul is good? So other answer can I give, callicles dear. . . If the temperate soul is the good soul, the soul which is in the opposite condition. that is the foolish and intemperate is the bad soul.

"And will not the temperate man do what is proper. both in relation to grols and usen: for he would not be temperate if he did not what is proper? Yes, certainly. And in his relation to other men he will do what is just, and in his relation to the gods he will do what is holy: and he who does what is just and holy cannot be ofleer than just and holy? Very true. And he must he (ouragenus, for the duty of a temperate man is not to follow or to avoid what he ought not. hut what he ought. whether things, of ment or pleasures. or pains. and patiently to endure what le ought: and therefore. Callicles, the temperate man, heingr. as we have deserileed, also just and rourageons and

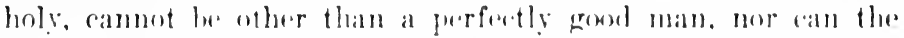
good man do otherwioe than well and perfoctly whatever he does: and he who does well must of meressity he haply and hloserd, and the ovil man who dow evil miscrahle."

As we sere happiness is hy no means identified with platsure. It consists in a certain virtme, in an order which eharacterizes the soml of the grexd man. 'The temperate soul is the good soul; the foolish and intemperate is the hat soul.

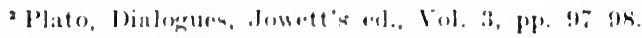


A similar doctrine is held by Aristotle. In the first book of his Nicomachean Ethics, he teaches that happiness is neither pleasure, nor honor, nor wealth, but "an energy of the soul according to virtue." These are Aristotle's own words :

"Men seem not unreasonably to form their notion of the good, and of happiness, from observing the different lives which men lead. The many and most sordid class suppose it to be pleasure, and therefore they are content with a life of enjoyment. $^{3}$

"But, perhaps, to say that happiness is the greatest good, appears like stating something which is already granted; and it is desirable that we should explain still more clearly what it is. Perhaps, then, this may be done, if we take the peculiar work of man; for as to the musician, and statuary, and to every artist, and in short to all who have any work or course of action, the good and excellence of each appears to consist in their peculiar work; so would it appear to be with man. if there is any peculiar work belonging to him...

"What, then, must this peculiar work be? For life man appears to share in common with plants; but his peenliar work is the object of our inquiry: we must, therefore, separate the life of nutrition and growth. Then a kind of sensitive life would next follow; but this also he appears to enjoy in common with the horse, the ox, and every animal. There remains, therefore, a certain practical life of a being which possesses reason; and of this one part is, as it were, obedient to reason, the other as possessing it, and exercising intellect. But this life also being spoken in two ways (according to energy and according to habit), we must take that according to energy; for that appears to be more properly so called. Now if the work of man, and of a good man, is the same generically, as in the case of a harper, and a good harper (and so, in short, in all eases, superiority in each particular excellence being added to each particular work); for it is the work of a harper to play, of a good harper to play well: and if we assume the peculiar work of man to be a kind of life, and this life an energy of the soul and actions performed with reason; and the peeuliar work of a good man to be the same things done well, and honorably; and everything to be complete according to its proper excellence:

-Aristotle, Nicomachean Ethics, Bk. 1, chap. .7; Browne's ed., p. 7. 
if, I repeat, these things are true, it follows. that man's chicf good is " an energy of the soul aceording to virtue ": but if the virtues are more than one. aceorling to the best and most perfect virtue: and besides this, we must add, in a perfect life: for as neither one swallow, nor one day, makes a spring: so neither does one day, nor a short time, make a man blessed and happ!.".

Let us now direetly examine hedonism itself.

In the first place. it counds like a truism to say that the words "grood" and "pleasurable" (anmot be unplablitiedly taken as convertible terms. The common helief of mankind looks upen as good many actions that do not bring any real pleasure to their authors. The payment of a dehte charity to the poor, self-sacrifiee, are praised all over the world. On the other hand, many acts hringing great pleasure are universally condemned. The drunkard and the libertine are objects of contempt to every right-thinking man.

Hedonists meet this objection by saring that the platsure given as the hasis of our conduct is not the particular pleasure of the moment. but the pleasure in the long run. 'The presently expected satisfaction is a worthy motion of action only in so far as it does not make impresible the attaimment of a satisfartion more remote. Althomgh in some particular casese the pursuit of a proximate satisfaction is mot to be comsidered as inferior to that of ultimate gratifieations, it is nome the lese a fondamental principle that the gruidance hy simple and immediate foedings must he subordinated to the antherity of higher and more complex feelinges.

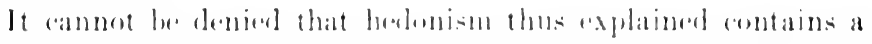
great deal of truth. The egroist ic element of all our acts must

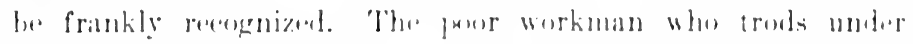

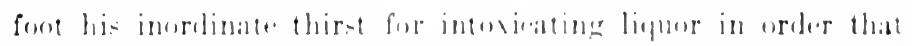

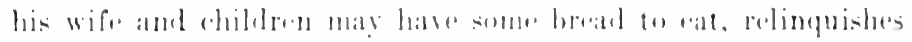

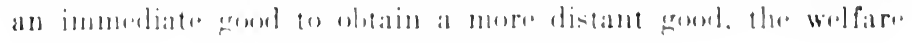

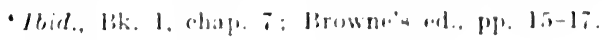


and happiness of his family, and, as a consequence, his own peace and joy at home. The sister of charity, who leaves her home and parents, who renounces forever the most legitimate joys of life, the pleasures that the matrimonial state and the rearing of children would bring to her; who spends her days and her nights at the bedside of a poor sick man whom she has never met before, to whom she feels attached by no earthly bonds, whom nevertheless she attends with all the painstaking cares of a most devoted mother, whom she finally snatches from the claws of death, expecting no earthly reward, knowing full well that the only prize of her self-abnegation will be an untimely death; this sister of charity, whose whole life seems to be a glowing impersonation of altruism, is, from a herlonistic point of view, just as selfish as the most vulgar man. She renounces the pleasures of this world to enjoy the pleasures of the world to come. She abandons relatives, riches, life itself, all finite and perishable goods, to secure the possession of treasures that never fade nor grow old. The prize she covets is none less than God himself.

Pleasurable actions, however, can be made co-extensive with good actions only in assuming there is a future life. As many hedonists would be loath to take such a life into account, would rather profess with Hegel that this every-day world, what is here and now, has been a very good exchange for the shadowy otherworld about which ancient philosophers worried themselves sick, there will come in their way a great many facts which their system-in the form we are at present considering-will be unable to explain. No future gratification, if we simply consider this actual world of ours, can possibly accrue to the soldier who, in a brave fight against the foes of his country, dies the death of a hero on the battlefield. If he is unknown to the world, he will not even reach the glory of having his name recorded in the annals of his country; he will not be held up to the school-boys of future generations as the ideal citizen. Obscure in life; still more obscure in death. No man, however, 
would call into question the intrinsie worth of his heroie death.

Facts of this kind have calued the downfall of individual hedenism and griven birth to the celehrated formulat, so universally admitted hy hedonists to-diay: " the greatest good for the greatest number." In this new form of the ststem, not only must immediate satisfactions give way to sittisactions more remote, but the present and the future pleasures of the individual must be subordinated to the pleasures of the whole community. .ll forms of self-sacrifien are thus easily justified. The sister of eharity will die in her prime of life at her post of duty, hut the hundreds of unfortunate people whom she has rescued from death will live and society will be benefited. 'The hero will be killed on the battlefield, but his eountry will be silved.

Sheholatice moralists would admit that pleature and good are co-extensire. If good actions are these performed in harmony with our nature, they must needs produce pleasurable results at the present moment or at some future time. We camot deny this principle without denying the rational character of omr world. And as here below many deeds, universally regarded as groed, do not give rise to any pleasurable conserpuences there must exist a more perfect worlel, in which whatever serms irrational in this will be reetified. lout, although pleatsure and good are co-extensive, they are far from being identical terms. Pleasure bears to grood the relation of an effect to its cautse. 1 grood artion will produce platurable results: but it will produce them on aceount of its own inherent nature. The gromblness will belong to the elements of the aretion itself, reagratless of the consengeneses that may posibly follow from it. A ripe apple will grive riot to pleasut grutatory impressions, but those impresions will he due to the perenliar nature and disposition of the atoms of the apple it sulf, which will thus possess an intrinside Enodness, independently of the sensitions it may produce. And if the apple decalse it is in the apple itself that a change from goost to had will ocenr: it will he bad eren if nobody ever tastes 
it. What is true of an external object is likewise true of all that belongs to the inner nature of man. All our acts possess a value of their own, which must be regarded as primary, while the ensuing consequences are looked upon as only secondary. The good is thus identifiable with what is in harmony with our nature. But as we are endowed with several orders of faculties, as we are made up of body and soul, and thereby possess a sensuous and an intellectual appetite, the gratification of our lower impulses must be subordinated to our nobler energies. We must live according to our nature, but to our whole nature. The satisfaction of a sensuous desire is thus good in itself, but becomes bad if the exercise of a nobler faculty is thwarted thereby:

“Delectationes corporales," says St. 'Thomas, "sunt secundum partem sensitivam, quæ regulatur ratione: et ideo indigent temperari et refrænari per rationem."

The assertion that the satisfaction of a sensuous desire is good in itself puts Scholastic moralists in conflict with the author of the Critique of Practical Reason. According to Immanuel Kant, a work is good when it is done, not only from duty, but from pure duty. ${ }^{6}$ Whenever some natural impulse furnishes the motive of a good deed, this deed is thereby deprived of its moral worth. Our actions must spring from duty alone, and not from any natural inclination whatsoever:

"To be beneficent when we can is a duty," says Kant, "and besides this there are many minds so sympathetically constituted that, without any other motive of vanity or self-interest, they find a pleasure in spreading joy around them, and can take delight in the satisfaction of others so far as it is their own work. But I maintain that in such a case, an action of this kind, however proper, however amiable it may be, has nevertheless no true moral worth, but is on a level with other inclinations, e. g., the inclination to honor, which, if it is happily

"Thomas Aquinas, Summa Theol., 1-2, Q. 31, art. 5. ad 3.

'Kant, Critique of Practical Reason and other works, Abbott's ed., p. 23. 
directed to that which is in fact of public utility and accordant with duty, and convepuently homorable, dererve praise and encouragement. but not estem. For the maxim lacks the moral import. namely, that such actions he done from duty, not from inclination. $" \bar{r}$

Kant s. rstem of morals, perfectly correct in so far as it recennizes that moral ald tons must spring from our own individuality. not from any external principle, correct also when it points out the insufficineng of hedonism. fails to recognize the legitimacy of our natural inclinations. Inconsistent when he divides our mind into two compartments, and sets the practieal agatinst the fure reason, the solitary of komigraberg is grulty of a similar inconsistency in his practical realm. He plits up. as it were. our intimate solf, opposes one part to another. dherishes one fragment as genuine and praiecwertly, rejects the other as spurious and baneful. It prostrates himself before the eategorical imperatiwe, which indeed originate from the wery depthe of our soul, is (iod himself speating to our heart and making us krow our duties through the volec of our own nature: but, at the same time. he comdemus, ats adequate moral motives, those cravinge, these natural atpirations which form, at well as the velee of pure duty, a comstituent part of our own sulpes. His syotem, repulsive to the ordinary man for its harremenes incongruous with the common heliefs of mankind in so far at it deprives of moral worth not only the eharity of the frowd-natured man, but the arerifien of the here whe dies for his country, is inadmisible in the world of thought herame it makes man a mere bumlle of entralletery elements.

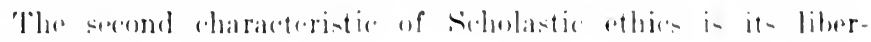
tarianism.

'The doetrine of free will has been so often mirregresented, and rejected on that aceoumt, that a few explanatory remarke will men les out of place here. It is quite absurd to call a fres.

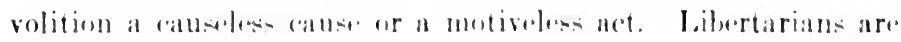

'Mid.. P. 14. 
far from teaching that free actions are done without a motive: they simply contend that the motive does not necessarily determine our will. Our will, they say, is a rational faculty whose object is the good. Now a good determines our will only if it is good in every respect. As long as there remains in it some undesirable aspect-as is the case with all the finite things of this world-our will has not what it naturally tends to, perfect happiness, and is not therefore necessarily determined:

"Si proponatur aliquod objectum voluntati, quod sit universaliter bonum, et secundum omnem considerationem, ex necessitate voluntas in illud tendit, si aliquid velit: non enim poterit velle oppositum: si autem proponatur sibi aliquid objectum, quod non secundum quamlibet considerationem sit bonum, non ex necessitate voluntas fertur in illud."

The laborer who, after toiling laboriously for long hours every day, brings his wife the fruit of his toil and fatigue instead of spending it in a grog-shop, certainly acts with an end in view. He is determined by a motive; but his own consciousness eloquently testifies that this motive did not determine his will necessarily, that he might have acted otherwise.

Scholastics are unanimous in regarding free will, thus understood, as an indispensable presupposition of all morality. The recognition of this truth does not belong solely to them. Kant, whose philosophy lies open to eriticism in many other respects, joins here in perfect harmony with the teachings of the School. Free will has a conspicuous place in his system of ethies, is indeed its corner-stone. He regards it as an essential condition of all true morality.

If we start from fatalistic principles, if we regard all our acts as necessarily determined by our character and surroundings, all possibility of acting differently from what we did disappears, and the words merit and demerit lose all their significance.

It will perhaps seem strange that a philosophy professing to

'Thomas Aquinas, Summa Theol., 1-2, Q. 10, art. 2, c. 
be a resival of 'Thomism should defend any thesis of free will. Many non-('atholic writers, indeed, look upon st. Thomas as an angry determinist. We will limit ourselves to two quotations:

"In the first place," says Fullerton, " it may help one to realize how erroneous is the current notion that this doctrine (of free will) has some natural connertion with religion and grood morals. and that they may be expected to be found in conjunction. When stoic and Epicurean are placed in contrast, it is certainly not to the advantage of the latter. And surely no man ean regarel Augustine an less religious than Pelagius, St. Thomas as less relgrious than I buns Scotus, Luther as less religious than Fratmus, and Jansenius as lese roligious than his Jesuit opponents. A glance at the history of human thought rempts one to maintain that men of strong religious forling are less likely to become "free-willists" than other men. Their perculiar danger appears to he a lapse into some sort of fatalism."

Our second quotation will be taken from the sisiss philosopher, ('harles sécretan:

"Il (st. Thomas) attribue la coulpe an libre arbitre de la volonte: "Hoc enim imputatur alieui in culpam, quum defieit a perfecta actione cojus dominus ast secundum voluntatem. . .

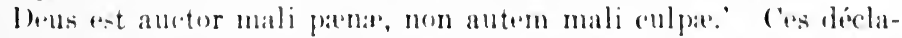
rations semblent precises, mais elles ne sanraient tenir devant le detorminisme absolu qui forme la base de tont le systime."10

And a little further on he contimues:

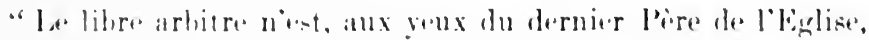
que la faculte de siearter de la raicon. Il noest done pas ques-

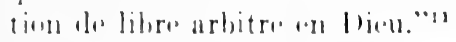

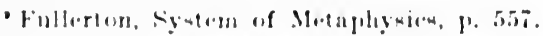

"Seretan, la Rostauration du Thomiame; Rer. Philos., Vol. 1s, p. is.

"Itsed. p. is. lat us compare with this last statement the following pasager from st. Thomas's summa contra fientiles:

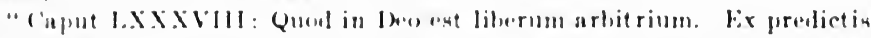
autem ontendi potant, qual in loos lilermm arbitrium inwentur, nam

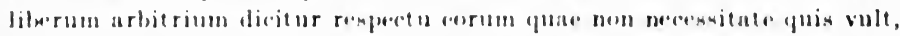

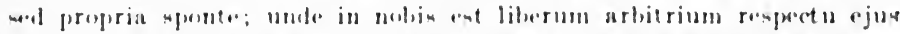

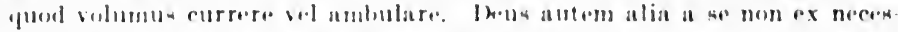

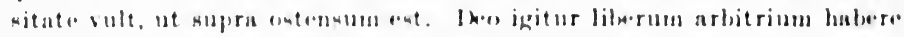

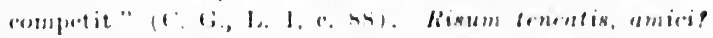


Sécrétan, however, does not feel perfectly at ease. He feels no doubt about St. Thomas's strict determinism. Nevertheless, he is compelled to recognize, in the works of the Angelic Doctor, some teachings sounding very much like an admission of free will. He concludes that a contradiction permeates the whole system :

"En contradiction flagrante avec son déterminisme, avec son optimisme absolu, avec ses doctrines sur l'étendue de la causalité divine et sur la prescience de tous les futurs, Thomas professe catégoriquement le libre arbitre."12

Let us now turn to the works of St. Thomas himself and see whether he would accept as his the doctrines thus imputed to him. We shall confine ourselves to a few striking passages, and refer those who should desire more abundant information to the Summa Theologica, the Summa contra Gentiles and the Opuscula, of which a thorough study is necessary for a complete understanding of the philosophy of St. Thomas, and in which the point which interests us at present is repeatedly and adequately discussed.

In the Summa contra Gentiles, St. Thomas teaches that all intellectual substances are endowed with free will:

"Caput XLVIII.-Quod substantiæ intellectuales sunt liberi arbitrii in agendo. Ex his autem apparet, quod prædictæe substantiæ sunt liberi arbitrii in agendo. quod enim arbitrio agant, manifestum est eo quod per cognitionem intellectivam judicium habent de operandis. libertatem autem necesse est eas habere, si habent dominium sui actus, ut ostensum est (c. 47). Sunt igitur prædictæ substantiæ liberi arbitrii in agendo."13

He gives his view on Divine Providence, and professes that it does not interfere with the free will of man:

"Caput LXXIII.-Quod divina providentia non excludit arbitrii libertatem. Ex quo patet quod providentia divina vol-

${ }^{12}$ Ibid., p. 82.

${ }^{18}$ C. G., Lib. 2, c. 48. 
untatis libertati non repugnat. . . Per gubernationem cujuscumque providentic, rese grubernatid deducuntur ad finem con-

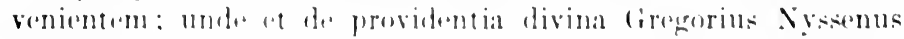

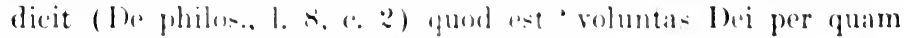
omnia quar - -unt romsententem deductionem alecipiunt. Finis antem ultimus cujuslibet creaturar ent ut consequatur divinam

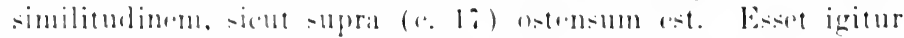
providentiar repugnans. i alimi ri subtraheretur illud, fuer quod as sopuitur smilitudinem divinam: agens antem roluntarium arefputur divinam smilitudinem in hoe, qued libere agrit:

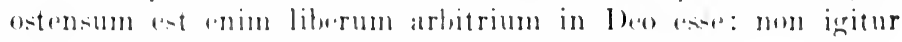
per providentiam prohibetur woluntatis libertas." "

In the sime chapter, he formally condemns the determinism of the stoine:

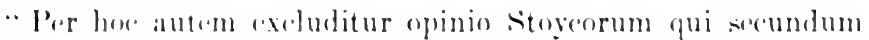
ordinem quenlam alusarum intransegresibilem, quen firaci

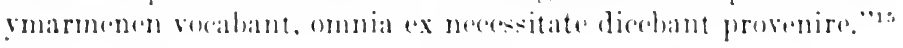

In his siumma Theologica, his most perfect work, the fruit of his maturer sears. in which the thought of his whole life is eonAnerde the same truths are again and agrain enunciated. In the s.3d chapter of the first part. he unequisocally admits fren will in man:

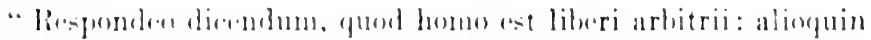
frustra centent comsilia, exhortationes, precepta, prohilitiones,

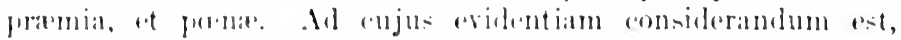
qued quatedan agunt abseque judicio, sicut lapis mowetur derorsum: "t smiliter omnia congutione carential. Quadam autem

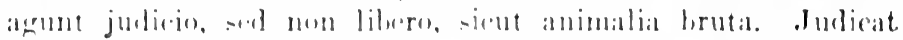
com ovis videns lupum, rum ase fugromdum, naturali judicio, "t non litwero: quia men ex collatione, sod ex naturali instinctu hor judicat: "t simile ent de quoliter judicio brutorum anima-

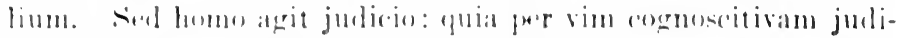

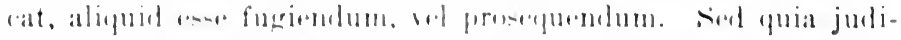
cium intud non est ex naturali in-tinctu in particulari operabili, and a collatione quadam rationic, iden agrit libero judicio, potens

$$
\begin{aligned}
& \text { - ' . ci, lih, 3, r. } 73 .
\end{aligned}
$$

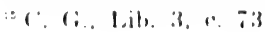


in diversa ferri : ratio enim circa contingens habet viam ad opposita, ut patet in Dialecticis syllogismis, et Rhetoricis persuasionibus: particularia autem operabilia sunt quædam contingentia et ideo circa ea judicium rationis ad diversa se habet, et non est determinatum ad unum. Et pro tanto necesse est, quod homo sit liberi arbitrii ex hoc ipso, quod rationalis est."16

He even teaches that free acts are the only acts that may properly be styled human:

"Respondeo dicendum, quod actionum, quæ ab homine aguntur, illæ solæ proprie dicuntur humanæ, quæ sunt propriæ hominis inquantum est homo: differt autem homo ab irrationalibus creaturis in hoc, quod est suorum actuum dominus; unde illæ solæ actiones vocantur proprie humanæ, quarum homo est dominus; est autem homo dominus suorum actuum per rationem et voluntatem; unde et liberum arbitrium esse dicitur facultas voluntatis, et rationis; illæ ergo actiones proprie humanæ dicuntur, quæ ex voluntate deliberata procedunt: si quæ autem aliæ actiones homini conveniant, possunt dici quidem hominis actiones, sed non proprie humanæ, cum non sint hominis, inquantum est homo." 17

He discusses the relations of God to man more closely still than in the Summa contra Gentiles, and reaches the same conclusions :

"Quia igitur voluntas est activum principium non determinatum ad unum, sed indifferenter se habens ad multa; sic Deus ipsam movet, quod non ex necessitate ad unum determinat, sed remanet motus ejus contingens, et non necessarius, nisi in his, ad quæ naturaliter movetur."18

Therefore, there cannot be the slightest doubt as regards St. Thomas's libertarianism. It must be admitted, however, that a peculiar doctrine of his, universally accepted by his modern followers, seems, at first sight, to be hardly reconcilable with human liberty; it is the doctrine of prescience, predestination

\footnotetext{
${ }^{10}$ Summa Theol., P. i, Q. 83, art. 1, c.

${ }^{17}$ Ibid., 1-2, Q. 1, art. 1, c.

${ }^{19}$ Ibid., 1-2, Q. 10, art. 4, c.
} 
and reprobation. St. Thomas asks whether men are predestinated by God, and he unreservedly answers that they are:

" Ineo conseniens est homines prapdestinare."19

He adds that cind reprobates some men $;^{20}$ that the elect are chosen by Him:

- Inde pradestinatio al iqporum in salutem eternam prap-upponit serumdum rationem, quod Dens illorum velit salutem. Id guod pertinet alectio, at dilection":?1

that the number of the elect is certain not only formally, but materially; that is to say, fiod does not only know how many men will be saved: but he also knows whether John. Peter and Thomas will he saved:

"Responder dicendum, quod numerus predestinatorum est certus. Sed quidam dixerunt, etum csese certum formaliter, sed non materialiter: ut puti, si diceremus certum esse, quod centum, vel mille salventur, non autem yuod hi, vel illi. Sed hoc tollit certitulinem predestinationis, de qua jam diximus. Et illoo oportat dicere, guod numerus predestinatorum sit certus bero non solum formaliter, sed etiam materialiter."

It is thus edear that, aceording to this view of st. Thomas, ford knows all future events: that, his knowledge being immutable, all things will necessarily come to pass as he actually know: them; that the number of the aleet is thus determined: that cord knows, with regard to any man, not only whether he will be saved or dammed, but what the determination of his will will be in each particular case: that there is not the slightent fer-sibility for any one of us to change in the last dengree ciods cternal and immutable dereses in our regard.

Whe de not deny that there is here an appareme clash with st. Thomas's teaching ahout free will. The opposition of the two

- Mud., I 2, (2, 23, art. 1, c.

* libil., 1-2, 4. 23. art. 3.

"llial., 1 2, 4. 2:3, art. 1. c.

zlbid, I $2,4,23$, art $, 3,4$ 
doctrines, however, exists only in appearance, and disappears as soon as we grasp St. Thomas's conception of God. His theory of the Divine Being has been exposed in our chapter on Natural Theology. Suffice it to recall that God being eternal, there is no future for him, but a perpetual present. He has not existed through an infinite temporal series, a series of successive instants of which there was no beginning and which shall know no end; he even does not properly exist: He is. What is a future for us is thus not a future for God, and it is only an imperfection of our language that compels us to speak of God's prescience. He does not know our acts before we perform them; he knows them as actual. His knowledge is not logically anterior, but posterior to the free determination of our will. It is hard for us, of course, limited as we are to our temporal series, to have a clear coneeption of a knowledge of this kind. We may, however, have an idea of it-though imperfect-by considering our own knowledge of the present and of the past. We actually know that John has done this and Thomas that, and our knowledge does not interfere in the least with the freedom of their actions. It is in a similar way that God knows our future deeds. He knows them as done. He predestinates some men beeause they freely act in accordance with the moral law; ho reprobates others because they freely disobey his precepts; he knows how many men will be saved just as we might know the exact number of soldiers who were slain at Gettysburg. 


\section{('HAP'TER VIII}

\section{FORERI NAER OF THE NEO SOHOLASTE REVIVAL}

The causes which led to the downfall of scholastic philosophy in the fifterenth eentury may be dassified as internal and external.

Among the external causes the most important are:

1. The humanistic movement which, by bringing to light the literary beauties of the pagan elassies, and insisting upon the form in which the thoughts were expressed rather than upon the thoughts themselves, was directly epposed to the spirit which had animated the schoolmen.

?. The rapid progress of natural scienere which, after having shown the insufficiency of the old physical syetem, extended its condemnation to the metaphysical principles with which this sytem was only aceidentally connected.

3. 'The rise of Protetantiom which, by its opposition to the chureh of Rome, lenl to the rejection of the principle of anthority and incited the minds of the new generation to deny or to guestion all that had leren held salered in the past.

4. The insention of printing, considered by Haturean as the

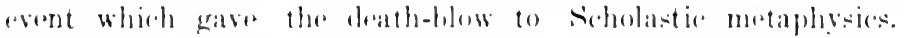
buring the thirtenth and fourtenth entury, all instruction was foreibly oral, and the great centers of larning, in which sicholastieism prodominated, were the only sourees from whieh

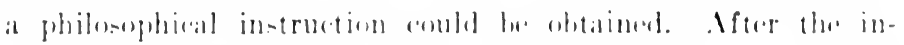

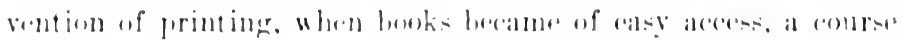
in the moiser-ities and to be indiepensable, and a new philos-

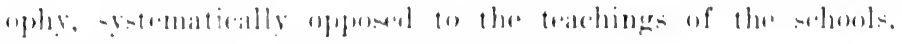

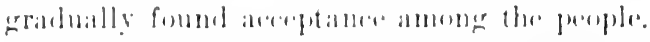

The sery supporters of sidhelasticiom rontributed, howeser, 
more than anything else, to discredit the system they were called to defend. The spirit which had animated the great masters of the thirteenth century had completely disappeared. Vain subtlety had replaced the profound reasoning of the past. The argument from authority, considered by St. Thomas as the weakest, had been raised to an undue importance. The new scientific spirit, into which the great Scholastics of the thirteenth century would have so eagerly entered, was opposed with unanimity by their degenerate successors. Instead of harmonizing their principles with the new physical discoveries, as Aristotle and Thomas Aquinas would have done, they opposed with all their might the very spirit of their time. They declared it to be opposed to the philosophical doctrines they cherished, and thus raised an unnecessary and unequal struggle, in which the old Metaphysics was doomed to perish.

Scholastic philosophy did not, however, completely disappear. An important movement of Thomistic revival took place during the sixteenth century and enriched Scholastic literature with many eminent contributions. Thomas de Vio Cajetanus (14691534), Vasquez (1551-160t), Toletus (1532-1596), Fonseca (1528-1599), and especially Suarez (1548-1617), were profound thinkers, worthy of the great masters whose principles they had adopted.

The influence exercised by the philosophy of St. Thomas during the seventeenth century was also considerable. Bossuet (1627-1704) and Fenelon (1651-1715), although controlled by Descartes to a certain extent, and sometimes regarded as Cartesians, developed a body of doctrines which is by no means opposed to the principles of the Angelic Doctor. Among the philosophical works of Bossuet, the Traité de la connaissance de Dieu et de soi-même, the Logique and the Traité du libre arbitre are of special significance. 'The philosophical doctrines they contain are evidently inspired by the teachings of St. Thomas.

Many writers of the same period were more strictly Thomistic 
still. John of Sarnt'Thomas (1.sig-16t1), Antoine Goudin (1639-1695), ('osmo Alemanni (15i9-16i34), caramuel (1606-

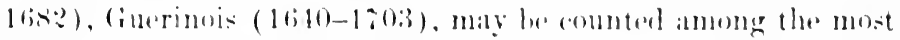
distinguished representatives of Sicholasticism. Siereral of their workis have been republished or studiend during the present century.

During the aighternth century, the philosophy of the shoolmen wats gradually abandoned. 'The theories of lacke and condillar found their way into many catholie centers. Amongr the defonders of 'Thomism at that time, we may mention the Finniard Valearcel, who devoted his efforts to the refutation of Descartes, Sipinoza. Malebranche and Locke; the Jesuit Barthélemy des bosses (1688-1738), who correspombed with Wolf and Clarke and translated Leibniz's 'Theodicy : the Dominican Roselli, whose summa l'hilosophica is side to have inspired the neo-Thomists of thr nineternth century.

At the hegrinning of the ninctenth antury, the philonplisy of st. Thomas had been almost completely abomdomed. ('atholies themselves wore strivine to buld independent syomes of thought. In Italy, the santly fommler of the lartitute of

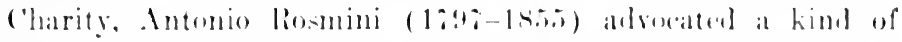
idealism which han been soserely altacked hy the arly Roman

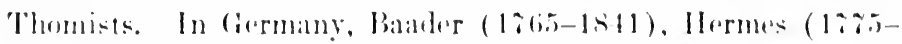

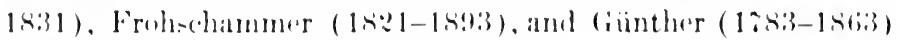

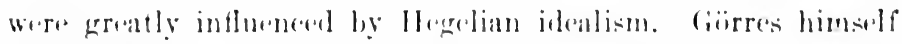

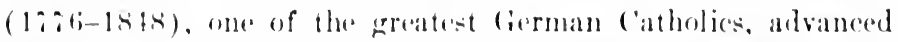

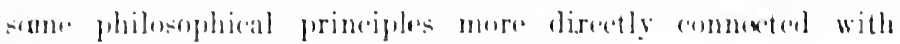
spirition than with Thomistir philosophy.

In Frante, traditionalism was in vogne. It was defonded by

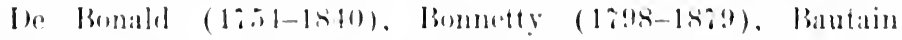

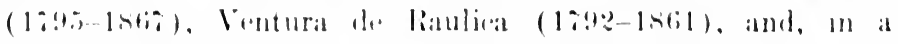
slightly molifiod form, hy lamemnats (17s:-1sid).

some works of lemtura are. howerer, permeated hy purely Thomistie principhes, on that their anthor maty jusly be refrarded as one of the immediate forerunners of the new)-siho- 
lastic revival in France. "In Father Ventura," says Cardinal Gonzalez, "two men may be considered. There may be seen, on the one hand, an enthusiastic admirer of St. Thomas, and, at the same time, a supporter of traditionalism, a disciple of De Maistre and De Bonald. In La Philosophie chrétienne, he is a genuine representative of Thomism, while in some other works, he seems driven by traditionalistic principles to the very limits of orthodoxy and reason."

During the first part of the nineteenth century, there were many signs of a return to the Middle Ages. The romantic movement in France strove to direct literature towards Mediæval customs and history. Hugo's "Notre Dame de Paris," published in 1831, contains a vivid picture of the life of Mediæval Paris. In other fields of human speculation, similar attempts were made. The philosophers of the Middle Ages soon became an object of general interest. Not long after the publication of Notre Dame de Paris, Victor Cousin (1792-1867) made known to the world unknown works of Abelard and Roger Bacon and published those learned studies about the Middle Ages which must be regarded as one of his most genuine titles to the gratitude of philosophy.

At the same time, another eminent scholar, Charles de Remusat (1797-1875), following the same line of research, wrote about Abelard, Anselm and Bacon. Barthélemy Hauréau (1812-1896) published his remarkable works on the Middle Ages. The great Scholastic philosophers were at last emerging from the oblivion to which they had been so unjustly condemned.

In other European countries, identical tendencies could easily be discerned. In Germany, Friedrich Schlegel (17r21829) had already shown the real merit of Mediæval philosophy in his famous IIistory of Ancient and Modern Litcrature. Among Catholic thinkers, a return to Thomistic principles was then effected. Möhler and his illustrious disciple Stauden-

${ }^{1}$ (f. Gonzalez, Historia de la Filosofia, V. 4, pp. $428 \mathrm{ff}$. 


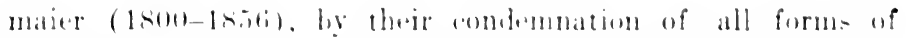
rationalism and their striet orthodoxy, prepared the minds for

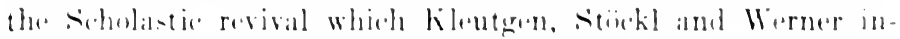
allguralted so hrilliantly in tiormany.

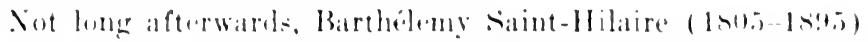
translated the works of Aristente, and Feblix Ravaisong published

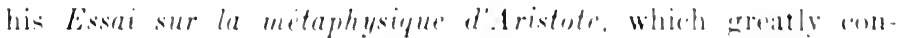
tributed to impere the peripatetic spenculation upun the attention of the world. The waly was the fully prepared for tiansoverino and kleutgen. 


\section{CHAPTER IX}

\section{THE NEO-SCHOLASTIC REVIVAL IN ITALY}

The direct initiator of the neo-Seholastic movement in Italy was Cajetano Sanseverino, canon of Naples.

Sanseverino (1811-1865) was at first an enthusiastic admirer of Descartes. The episode of his life which marked the turning-point of his philosophical career has been told by many historians. In the year 1840 , Sanseverino received the visit of Father Sordi S. J., who had read and annotated St. Thomas's Summa Theologica. Sordi pointed out to Sanseverino the shorteomings of Descartes's thought and the superiority of the Thomistic principles in the solution of all philosophical problems. Great was the struggle for the devout canon. For twenty years, he applied himself to a thorough study of St. Thomas's philosophy. At the light of the Summa Theologica he read all modern writers and became more and more convinced of their insufficiency. The result of his investigations was the Philosophia christiana cum antiqua et nova comparata, a work which, unfinished as it is, consists of seven quarto volumes and displays an uncommon erudition, a remarkable knowledge of modern philosophy, and, above all, an enthusiastie admiration for the Angelic Doctor.

According to Cardinal Gonzalez, the Philosophia christiana has a double defect. With regard to its method, it presents a somewhat awkward distribution of arguments, and, at times, exceedingly diffuse articles. With regard to its spirit, it is too narrowly attached to the philosophy it defends. Sanseverino accepts St. Thomas's conclusions even in the minutest details, and despises modern thought as altogether vain and worthy of contempt. ${ }^{1}$

${ }^{2}$ (ff. Gonzalez, Philosophia elementaria, pp. 383384. 
In spite of these defects, the Philusoghia christiana has exercised an immense influenere upon ('atholic thinkers. For many years, it has been the great work of neo-seholasticism, the fountain at whose pure waters all came to drink the spirit of the Thomistic regeneration. In its narrow-mindedness itsolf, it has found a multitude of followers. 'Too often have neoScholasties shared sanseverino's contempt for modern thought. 'They have not even taken the trouble to read non-sicholastic writers in their original works. Why submit, indeed, to such a wearisome task? Had not Sanseverino done the work once for all? Had he not, from the narrowness of his cell, pronounced an ultimate verdict upon modern thinking? And thus, Sanseverino's word has been taken, not only with regard to the exposition of modern philosophical systems, but also with regard to his very criticisms.

The Philosophia christiana was at first the object of violent attacks. ('artesians and Rominians agreed in denouncing it. But Sanseverino was defended by his disciple signoriello, and encouraged by his archbishop, Riario sforzal. Shortly afterwards, an Academy of St. Thomas was founded at Naples, and honored by the approbation of Pins IX. All semed to indirate that the efforts towards a Thomistie revival would be rowned with suceess.

The arehiepiscopal see of Perusa was then ocenpied by Joachion Peceri who, as warly as 1858, had founded an Acalemy of sit. Thomas. Peece was in elose connetion with cardinal sforma, with whose coëperation he had already written a refutation of Ontologiom. II, gratly smpathized with the Thomistie revisal which was taking plater in Saples, and addresed a memoir to Pius IX, atking him to declare st. Thomas patron of the universities.

At the same time, there lived, in another point of the Italian perninsula, a remarkable man, who was destined to be the sery life of the new mosement, to impose it bon gre mal gre, and 
to silence all malcontents. It was the famous Jesuit John Mary Cornoldi.

Cornoldi is undoubtedly one of the most interesting figures of the neo-Scholastic revival. As soon as he heard of the work done in other places, he intended not to remain behind. Academies had been founded in Naples and Perusa: he would found in Bolonia an Academy of his own. Unwilling, however, to be a mere imitator, he made up his mind to create something truly original. The two other Academies were simply philosophical; his would be medico-philosophical. The Academia filosoficomedica di san Tommaso was accordingly founded (1874), in which Travaglini, Venturoli and Zanon represented science; Cornoldi, Battaglini and Rubbini, philosophy. The review La Scienza Italiana, the organ of the new institution, has been published until 1891.

In the Roman universities, however, 'Thomism did not as yet seem to gain a footing. The philosopher most in view in Rome at the time was the Jesuit Tongiorgi, a remarkable thinker, sometimes called by his admirers "the Balmes of Italy." On the whole, Tongiorgi's philosophy may be regarded as Thomistic. The few questions in which he departs from Scholastic principles are precisely those in which Scholastic principles are the weakest. He thus refuses to admit the theory of Matter and Form as an adequate explanation of the nature of bodies, and advocates a kind of Atomism. Nevertheless, Tongiorgi felt no sympathy for a revival of Thomism.

Such was the state of affairs when, in 18r8, Joachim Pecci was elected Pope. The situation was at once greatly changed. Pius IX had sympathized with the Thomistic revival. He had even sent a letter of approbation to the archbishop of Naples. In Rome, however, unwilling to vex his anti-Thomistic professors, he had done nothing. As we shall see, the new pope will not hesitate to act more resolutely.

In the very letter in which he announced his elevation, Leo XIII quoted from the text of St. Paul: videte ne quis vos 
decipiat per philosophiam. and greatly commmended the philosophy of st. Thomats as the true philenphy. The Roman college at one aldopted the virwe of the head of the church:

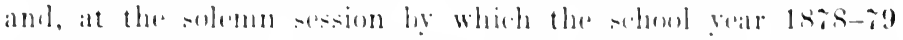
opened, Father cardellat, speaking in the name of all, declared "that he would take st. Thomals ats the rule and late of his teiching.".".

The peope wat delighted. His lioman profenors, whom he

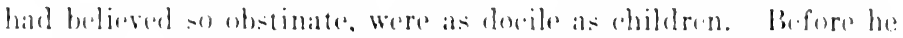
hat sald a word, they had understood and antiogated his wishes. So perfect senemed their dispositions! so splendid were their promiere: I'nhappily they were promises only and nothing was done. Father Palmieri, who hat taken Tongiergi"s place. not only did not ane in aceordanee with the papal instructions, hut applied himself to point out from his chair the inconsistenciess of st. Thomas's thought, the contratlictions to which Sicholaticism neersarily leads. As for carenti-Palmieri"s (co-worker-he did not dare depart a whit from his dear

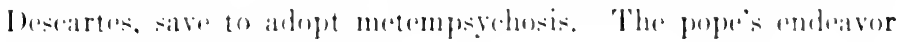
was deridedly is that falilure.

What rould be done: la dill: own brother and co-

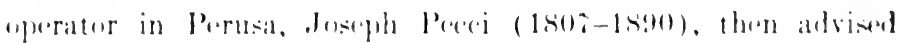
him to establish in Rome at frese course of Thomism and to confuld it a Father comoldi. The advion was judgend excellent and inmediately follewed. Cormoldi arrived at lemes promel of the reputation he hand graineel in Belonial as a repentist and a philosopher, and of the henorahle mision he had just received of implanting the philesphy of st. 'Thomas in the very capital of the ('hristian world.

Gormeldi: renre was apen to all the students of the Roman Iniwerity, and presiled he the regular profeserose of the Ro-

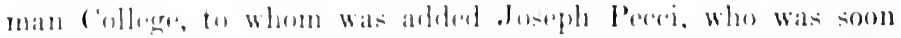

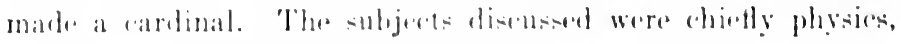

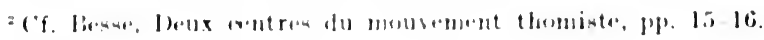


psychology and metaphysics. To all questions whatsoever, Cornoldi, St. Thomas in hand, could answer! In the Summa Theologica was to be found the key to all difficulties of modern science!

At the same time, there began to spread a rumor that Leo XIII was preparing an encyclical letter about Christian philosophy. The uneasiness of the Cartesian professors was growing day by day. That Thomistic revival they had so much despised when confined to Naples and Perusa, was now taking Rome by storm. The dreaded encyclical appeared. Leo XIII greatly commended the philosophy of Thomas Aquinas and insisted upon a study of the genuine works of the great Scholastics:

"Providete ut sapientiam Thome ex ipsis cjus fontibus hauriatur."

More than any other Scholastic must St. Thomas be studied because he gathered all previously discovered truths in a great synthetic system, which he still considerably increased:

"Illorum doctrina, velut dispersa cujusdam corporis membra, in unum Thomas collegit et coagmentavit, miro ordine digessit, et magnis incrementis ita adauxit, ut catholice Ecclesia singulare præsidium et decus jure meritoque habeatur. "*

There is no part of philosophy which he has not solidly discussed:

"Nulla est philosophix pars, quam non acute simul et solide pertractarit: de legibus ratiocinandi, de Deo et incorporeis substantiis, de homine aliisque sensibilibus rebus, de humanis actibus eorumque principiis ita disputavit, ut in eo neque copiosa quastionum seges, neque apta partium dispositio, neque optima procedendi ratio, neque principiorum firmitas aut argumentorum robur, neque dicendi perspicuitas aut proprietas, neque abstrusa queque explicandi facilitas desideretur."s

${ }^{3}$ Encyclical Aterni Patris; In Thomas Aquinas's Summa Theol., Romae, 1894, Vol. 6, pp. $425 \mathrm{ff}$.

Ibid., p. 432.

'Ibid., p. 432. 
This return to the past, however, is far from being a retrogresion. All Mlediaval rain subtleties must be discarded. All scholintic teachings which are not in harmony with modern s.intific discoveries must be abandoned:

* Si quid enim est a doctoribus sicholasticis rel nimia subtilitate quesitum, vel parum considerate traditum, si quid cum exploratis posterioris avi doctrinis minus coherens, vel denique quoquo modo non probabile, id nullo pacto in animo est artati nostrat and imitandum proponi.".

Modern seintifie progress must be welcomed as a benefit to philosophy:

. Con cos profecto improbamus doctos homines atque solertes, qui industriam et eruditionem slam, ar novorum inventorum opes an excolendam philosophiam afferunt: id cnim probe intelligimus and incremental dectrina pertinere."

The influence of the perpes ancelical was simply immense. The revival of Themism, which had been limited to some isolated efforts, Wats then taken serionsly he most of the catholie thinkers. Suffice it to mention the celebrated profeseser of the

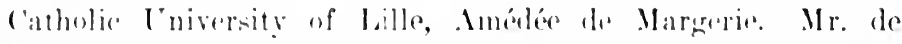
Margerie, altheugh more than fifty yars of age when the papal eneyclical appeared, at onere mande a thorough study of the works of st. Thomil-whith were completely nuknown to him -and adepted his doetrime in a great mang points.

In Rome itself, the sueness of the pepe was complete. This was due in great part to the fact that Lan Xlll, instructed by his first failure, took the precaution to corroborate his instructions by forcible measures. Palmieri and caretti were discharged from their chairs, and the new appointments made left no dentit at lo the final irsure of the afrair. All understood that this time the pene would be victorious.

The men hement by the papal ehoien as profesors of phi-

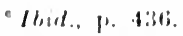

: lbal.. P. 4:34. 
losophy, in Rome, were the following: Cornoldi was made professor at the Roman College, Zigliara at the Minerva, Lorenzelli and Satolli at the Propaganda, Talamo at the Apollinaris. As all these men have distinguished themselves by eminent productions, I will say a few words about each of them.

Giovanni Mari Cornoldi, S.J. (182:-1892), besides his two great works: Institutiones Philosophia Speculative and La Filosofia Scolastica di San Tommaso e di Dante, and numerous shorter treatises in which he defends the Scholastic principles and attacks opposite doctrines, especially Rosminianism (Cf. Bibliography), has contributed many articles to the ciriltà Cattolica. Less profound as a philosopher than Zigliara or Sanseverino, he has nevertheless done the greatest service to the neo-Thomistic cause by the very activity he has displayed. The direct aim of his great works, as well as of his numerous essays, is most praiseworthy. He strove to point out the perfect harmony existing between Thomism and science, to give a scientifie basis to neo-Scholasticism. This is the very spirit which has recently inspired Desiré Mereier and the Institute of Louvain. Unhappily, Cornoldi's efforts have not always been intelligent and have met with little success. He is chiefly known to-day for his bitter eriticisms of modern thought. In his Prolegomeni, he divides all philosophers into three groups: the true philosophers, that is to say, the Scholasties; the liberal philosophers, or those who do not accept all Scholastic doctrines; the non-philosophers, to which group all others belong. ${ }^{8}$ Well known is Cornoldi's phrase deseribing modern philosophy as " the pathology of human reason."

Less unfair to moderns has been Thomas Zigliara, O.P. (1833-1893). His Summa Philosophica, in which he closely adheres to St. Thomas's doctrine, has, for a long time, served as a text-book in Catholic seminaries, and is much in use still to-day. His most valuable contribution to philosophy is prob-

${ }^{b}$ Cf. Gomez lzquierdo, Historia de la Filosofia del siglo XIX, p. 464.

- Cornoldi, Lecons de Philosophie Scolastique; Paris, 1878, p. 16. 
ably the work entitled: Mella luce intellettuale. The author refutes traditonalism and ontologism, and conclusively shows that the ontolocrists have no right to invoke the authority of st. 'Thomas to slyport their theorie's.

Pemedetto lorenzelli, actual arehbishop of laccal, has followed Arisotlo in his I'hilosephier Theoretion Institutiones. How aloely he shares ('ornoldits antempt for modern thought may he inferred from his division of philosophy into the four following periols: (1) a period of formation, from Thales to Aristotle: (:) a period of decrease and perversion, from Iristeite to cheri-t: (i) a period of increase and perfection, from chrint to Thomas Aquinas: (-1) a period of corruption, from J)arartes to our own day ${ }^{10}$

Francesor satolli is a faithful disciple of ('ardinal cajetan. At the example of the great commentator of the sixteenth century, he dhefly applies himself to the writine of learned commentaries on the werks of the Angelie locetor. In sinmmmm

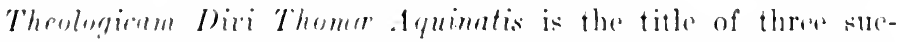
aesive treatios in which many questions of the summa Theologion aro expoumblod and sudind.

In his Ionge (Enrhiridion l'hilosophirr. l'ars Ia, continens

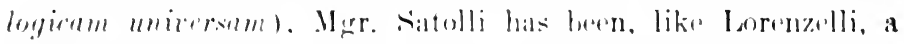
diseiple of Aristotle. Ho has lesen reproatehed with making an

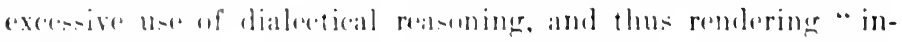
trieate and labyrinthe" what is elaar hy itsolf. Mis last work. J) holitibus, contains a valuable discusion of spencer's theory of combluct.

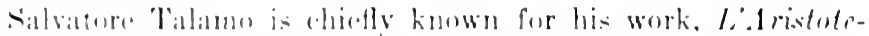

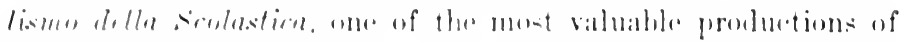

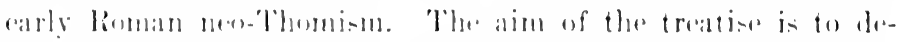

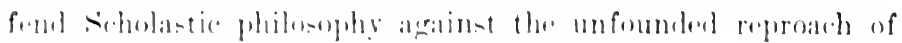

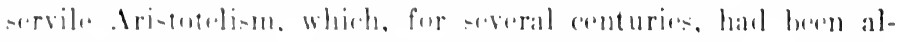

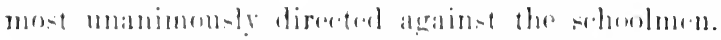

'The tirt ehapere of the work hat with the character of

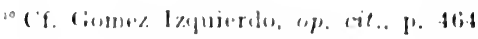


Medireval speculation. The author elearly shows that the philosophy of the schoolmen, although intimately connected with theology, had an object and a method of its own, with which theology was not concerned.

In the second part, the author studies the ground of the preference given to Aristotle in the Middle Ages. The reasons he assigns are the following:

1. Aristotle was the greatest master, nay the inventor of one of the most important branches of philosophy, the science of logic, which studies the laws of our mind and the method we must follow in the research of truth.

2. Aristotle's works contained a treasure of information about all branches of human knowledge: natural science, ethies, polities, psychology, metaphysics, etc.

3. Aristotle gave the example of a methodic discussion and a concise style, rejecting the beautiful garb under which Plato often concealed the impossibility of a demonstration.

4. Finally, the Stagirite revealed to the curiosity of the Mediwal philosophers the origin of philosophy and its development among the Greeks. ${ }^{11}$

The enthusiasm with which the philosophy of Aristotle was accepted was, however, far from mere slavishness. Whenever the Scholastics found in Aristotle some theory they judged erroncous, they did not hesitate to reject it. ${ }^{12}$ They likewise modified and perfected the system of the master in a great many points. With regard to the essential relations between the universe and God, the final end of man, the spirituality and immortality of the soul, etc., they taught definite doctrines which Aristotle had denied or very imperfectly treated. ${ }^{13}$ Their conception of the act of ereation was also essentially different from Aristotle's conception. Aristotle had admitted God as the

${ }^{11}$ Cf. Talamo, L'Aristotelismo della Scolastica, 3. ed., Siena, 1S\$1, pp. $234 \mathrm{ff}$.

${ }^{12}$ Ibid., pp. $151 \mathrm{ff}$.

${ }^{13}$ Ibid., pp. $361 \mathrm{ff}$. 


\section{1ii}

necessary cause of thre world, hut had regarded him simply as a demiurge acting upon otornally preëxisting matter. The Scholasties concerved areation as a production of the world out of nothing. it

While the proferors we have mentioned were working harel for the slleces of their aluse, there ame into notice another man who had not altracted the attrution at first, perhaps becatuse he shumned publice notice, who had written much, however, and who, from the silener of his cell, proved as able a dofenter of the new mosement as the men who were expounding their views from a unjureity a athedrat.

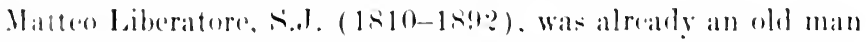
at the time we eonsider. His Institutiones l'hilosophiere puh-

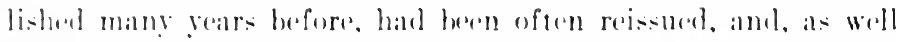

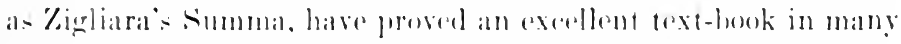
cathelie instimtions. Anticipatiner the pepes advice. Liberatore had shmmed all useless guestions and had defembed the esemtal principles of seholasticeism in a clear and elegant lan-

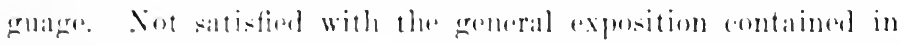
his fir-t work, he later touk up some spectal topies, ehietly in the

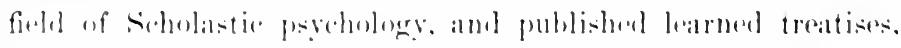
which hawe bent translated into varions languages (of. Bibliography). He even made use of the dramatie form to defond his

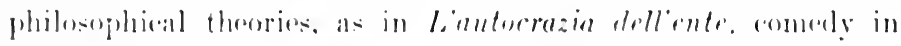

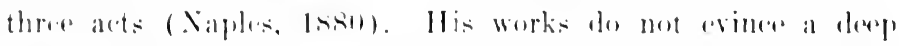
knowlonger of the philesophieal thomght ont-ide of Italy: but he has mastered lablian philosophy and given thorough reritioisms of the doetrines of Gioberti and lasmini. The latter part of his lifo was deveted to soreial sudies. Ho pointed ont the way in which the catholie Church can aleonmmolate itsolf to a cortain kind of socialism. Finally, Jiberatore was one of the foumblers of the reviow ('ililti ('attolien (1s.io), which has not (eaticed to he one of the most eflicient oreans of ('atholic thought in Italy.

"Ibill. p. 1.1. 
In the meantime, the success of the Roman professors was becoming more and more complete. In 1880, Leo XIII ordered the preparation of a new edition of the works of St. Thomas. At the same time, an Academy of St. Thomas was founded in Rome itself (October 13, 1879). It was composed of thirty members: ten taken from Rome, ten from the rest of Italy, ten from other countries. Pecci and Zigliara were chosen as presidents. ${ }^{15}$

The work of the Accademia Romana di San. Tommaso soon attracted the attention and the criticisms of the Italian thinkers. It was claimed that the new Scholasties were not following the precepts of Leo XIII, that they applied the Thomistic principles to scientific discoveries in the most ridiculous manner, that they had produced nothing original, save repeated attacks on Rosmini. These charges, formulated as early as 1886 by Benzoni in the Rivista italiana di Filosofia, have been taken up again by Besse, in his pamphlet, Deux centres du mouvement thomiste. The aim of Mr. Besse in this little treatise is to compare the work done at Rome by the carly neo-Scholastics with the work done at Louvain to-day, and to show that at Louvain only something truly philosophical has been accomplished; that the Louvain professors alone have acted in agreement with the papal instructions and with the necessities of our time.

The most important charges formulated by Mr. Besse against the Roman Thomists are the following:

1. On all points common to philosophy and faith, the Roman Thomists strove to connect the natural and the supernatural, and became mere interpreters of the Christian dogmas. ${ }^{16}$

2. They did not study modern philosophy, but uncritically acrepted Sanseverino's conclusions. Their criticisms, therefore, contain nothing personal, nothing serious, and have brought discredit upon the cause their authors pretended to defend. ${ }^{17}$

\footnotetext{
${ }^{15}$ ('f. Blanc, Histoire de la Philosophie, t. 3, p. 559.

${ }^{16}$ Besse, Deux eentres du mouvement thomiste, p. 25.

${ }^{17}$ Ibid., pp. 30-31.
} 
3. Lacking all principles of aritical method, the Roman Thomists have not esen succerled in their interpretations of it. Thomils.".

Mr. Bus expepts from his wholesile condemnation signoriello for his Vocalublarium peripatetico-scholasticum, and Talamo for his tuly on Aristotle. But these examples, the author continuts. hass found no imitators. ${ }^{10}$

The truth antained in .Vr. Besses pamphlet must be frankly acknowledget. Roman Thomists have often remained in al complete imorance of the spirit and the contents of modern philowphy. Without understamling molern thinkers. they have mereilessly condemmed them. Non-sicholistie philosuphical productions have been described as heretical ; their authore. "sen the most inotfensive. as men who had wilfully epposed all rules of common senere and truth. The neo-stholistic mosement has thes ontrateiged iteelf from the current of modern thought. It hats failed (1) attract the attention of the nomcatholie world. Its sery existence has been, for a loner time. rstomatically ignored. Only in recent years, and after taking another direction, hat mestidholasticiom heen deemed worthe of tudy. Only after neo-kintians have berome envinced that the profesers of Louvain possesed a knowledge of the Kantian philosephy which would honor any center of learning have they

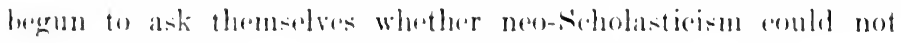
contain something gond, whether it is not a philosophy.

Mr. Beser. howerer, has probahly overlooked a most important fart, which might hase lect him to molify his sentenes of (onAnemation. The early Reman thomists were not in the same fureition as their followers of the present day. Their aim was

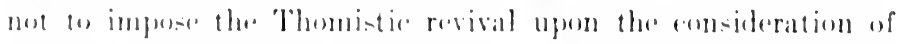

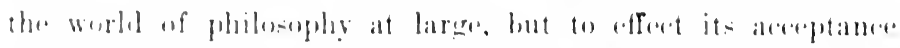
from the jart of the Catholie ('hureh. Only after Thomism had grained at sure fouting among ('atholice thinkers could it stop

- Mbel., p. 3.5.

. Ibid., p. 34, note. 
boldly forward and proclaim its existence to the outside world. This is the reason why the Roman Thomists have worked hard and fast to show the perfect harmony of their system with the body of revealed truths. It is the reason why they have made merciless attacks upon all other philosophies, and have seen a heresy where there was at most an error.

The neo-'Thomists of the present day ought not to censure too hastily the work of their older brethren. It is the Roman Scholastics that have firmly implanted Thomism in the Catholic world. They have faithfully grasped the task that lay before them, and have fulfilled it with the greatest success. The means they have taken were, on the whole, the best they could take, the only ones, perhaps, that could insure success.

The early neo-Thomists we have studied have found numerous disciples who have continued and perfected the work of the masters. In 1879, the Lazarist Albert Barberis (1847-1896) founded in Piacenza a Latin philosophical review, the Divus Thomas, which has been the organ of neo-Scholasticism in Italy, and in which Tornatore, Vinati, Ermoni, and other eminent men, have published learned dissertations. The professors of Louvain themselves have oceasionally honored the Dirus Thomas by their articles. Quite recently, the publication of the Divus Thomas has been interrupted. Nobody regrets the fact more sincerely than we do. It is perhaps true that modern languages are a more suitable instrument than Latin for philosophical discussions. All interested in neo-Scholasticism were none the less glad to read dissertations written by modern Scholastics in the very language of the schoolmen. After having enjoyed the Divus Thomas for so many years, we feel that its actual absence is a real lack to Scholastic literature, and we sincerely implore the distinguished professors of Piacenza to alter their decision and begin their work anew.

Barberis is also the author of two Latin dissertations: Positivismus ac nova methodus psychologica (188\%), and Esse formale estne rei intrinsecum an non? (188\%), which, by the solid- 
ity of the rasoning and the depth of the doctrine, asture their author a place among the most profound metaphysicians of our diay.

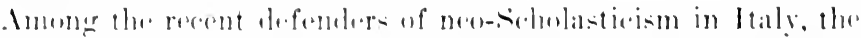

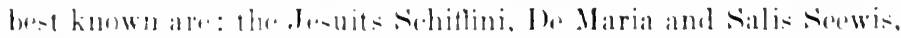

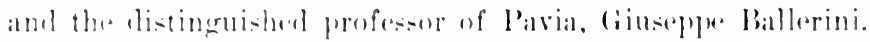

simte sibhttini (1st1-1!nti), for a long time professor at the

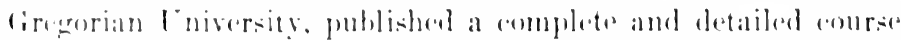

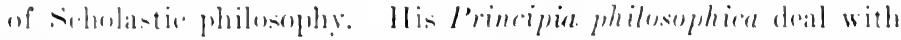
lenge and ontology: his Disputationes metaphysice sperinlis.

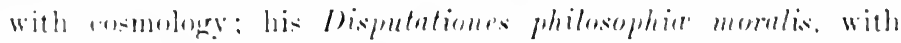
moral philosophes. In Less, in a learned article of the Aluneles de Philesophir chretione. Count Domet de Vorges praised

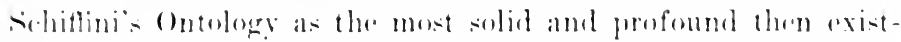

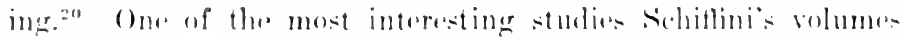
contain is an analysis of the influence of will upon belief, which reminds 11 o of the temets of our pragmatists.

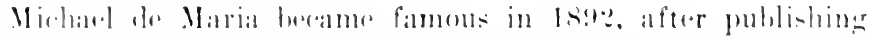

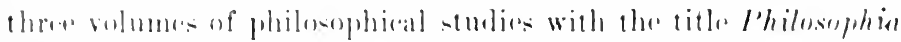

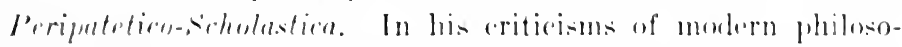

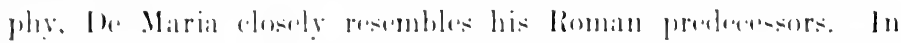
his comtempt for molern thought, he is not fir from cormolidi: postion, as maty be grathered from the following passigne of hiprefiare:

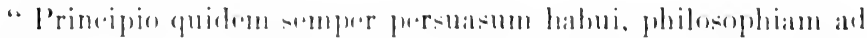

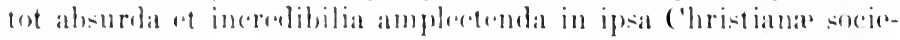
tatis luee en misere not ris temperibus declinasse quod paulatim

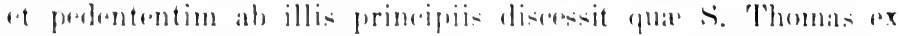
Aristotele alecepta mirifien illu-travit et cum ('hristiana revelat-

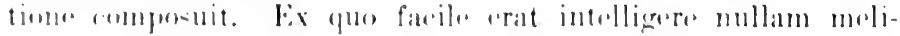

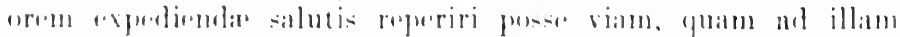
sapiontian plane resertio a quat incomsulte admodum of trmere

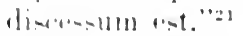

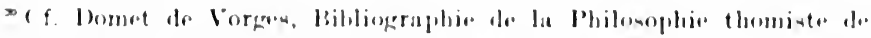

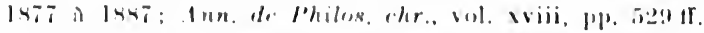

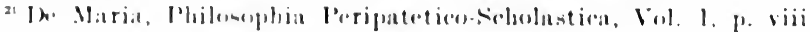


De Maria's work, however, is excellent in many respects. Besides its intrinsic value as an exposition of the Scholastic philosophy, it presents a special interest on account of the profound studies it contains about St. 'Thomas's doctrine on some spccial topies, viz., on essence and existence, ${ }^{22}$ on the nature of the individual, ${ }^{23}$ ete.

Francis Salis Seewis (1835-1898) is chiefly known for his treatise, Della conoscenza sensitiva, published in 1881, and a study of the doctrines of St. Augustine, St. Thomas and Suarez on spontaneous generation, published in $189 \%$. The author studies the Scholastic doctrines from the point of view of modern physiology and compares the teachings of St. Thomas with the positive results obtained in our day by Helmholz, Wundt, Weber, ete. By his careful study of modern scientific discoveries, Salis Seewis frankly departs from the contemptuous neglect of the early Roman Thomists and opens to the neoScholastic movement in Italy an era of progress. ${ }^{24}$

Giuseppe Ballerini, already known by a treatise on socialism and a theological dissertation about the Eucharistic dogma, published in $190 \mathrm{t}$ a study on the principle of causality and the existence of God, Il principio di causalita e l'esistenza di Dio di fronte alla scienza moderna. He regards the principle of causality as the real point at issue between the Scholastics and their opponents. He discusses its objectivity, combats Hume's theories, and shows the connection of the idea of cause with the belief in the existence of God.

A complete study of neo-Scholasticism in Italy should contain the names of the Jesuits De Mandato, Remer, and Taparelli d'Azeglio, the author of the celebrated Saggio di Diritto naturale; of Prisco, Chiesil, Cappellazzi, Puceini, and of the distinguished logician Lorenzo Schiavi. It should not fail to mention the accurate and painstaling edition of the works of St. Bona-

22 Ibirl., Vol. 1, pp. $441 \mathrm{ff}$.

${ }^{23}$ Ibid., Vol. 1, pp. $529 \mathrm{ff}$.

24 ('f. Comez Izquierdo, op. eit., p. 450. 
venture, begun in 18s: by the Francisean fathers of Quaracehi, near Florence, who have thereby done an immense service to the cause of schelasticiom. The same fathers are actually promising to the learned world a critical edition of the works of Roger Bacen. Finally, one of them, Mariano Fernamlez (iarcial, has just published a work which will be of great help for the study

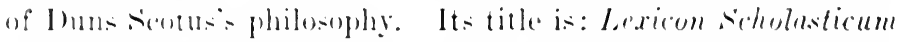
Ihilwsophion-Theologicum. in quo continentur termini, definitiones. distinctiones et effata a li. Joanne l) uns scoto loctore subtili. 


\section{CHAPTER $\mathrm{X}$}

THE NEO-SCHOLASTIC REVIVAL IN SPAIN, PORTUGAL, AND SPANISII AMERICA

\section{Section 1.-The Neo-Scholastic Revival in Spain}

Our ordinary philosophical studies in American institutions may easily lead us to the belief that there is no such a thing as a Spanish philosophy. Who, among our university students, has ever heard of a Spanish philosopher? Who could presently name one? Our complete ignorance on this point must perhaps be excused. Some years ago, Mr. Cuardia wrote an article in the Rerue Philosophique to prove that we are right. IIe gave it the attractive title of La misère philosophique en Espagne, and strongly defended the thesis that Spain possesses no philosophy. ${ }^{1} \quad$ The same thesis had been defended a few years before by the Mexican priest Agustin Rivera, who had extended his condemnation to the Spanish-speaking countries of the New World. ${ }^{2}$ Few Spaniards, however, would agree with these two men. Patriotism is strong beyond the Pyrenees, and the assertions to which it frequently leads the fiery sons of Pelayo would sound incredible to the eool-headed Anglo-Saxon race. It seems that the distinguished writer Marcelino Menendez y Pelayo has placed Spanish philosophy on equal footing with the philosophical systems of France and Italy, and has judged it inferior only to Greek and German speculation. To most of us, this judgment would seem rather bold. It has been condemned as too timid by William Gareia, who does not hesitate to give Spanish philosophy the first place. His line of reasoning is very simple. He summarily dismisses German philosophy

${ }^{1}$ Rev. Philos., 1893, pp. $287 \mathrm{ff}$.

In the work: La Filosofia en la Nueva España, Lagos, 1885. 
as a mere play of imagination and no knowledge of truth. As

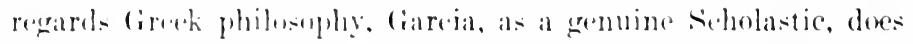
full justice to Aristotle: but, he adds. Aristotle has been surpassed hy st. Thomas, so that the Thomistie, or Italian philosofluy is really the firet phitosophy. Xow, the Thomistic philoso-

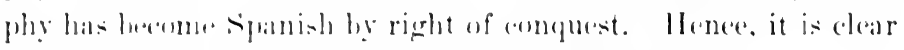

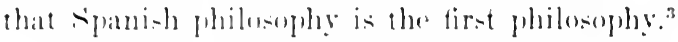

()ur helief at to the real worth of spanish thenght may be greatly inthenced by the point of view from which we study the que-time. I Kantian, for examples can hardly be proul of the influence the C'ritique of I'ure lifeson hats axereised on the spanish soll. If, as . Ir. Latinus points ont, only two spaniards. durine the nineteenth century, hase judged it useful to gro and sturly philosephy in Cormany, if the physician Nieto sorrano is actually the only Kantian in spain, all who maintain that

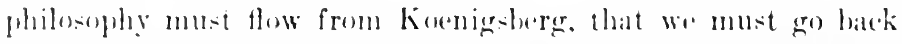
to Kant, will be apt to be as severe to spanish thomght as Rivera and Ciuarilia have besm.

A neo-sidelastice will no douth be more indulgent. Spain is perhalps the only anutry in which the sideolastie tratitions have never been entirely forgetten. A long time before sian-

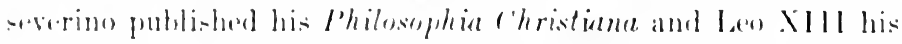

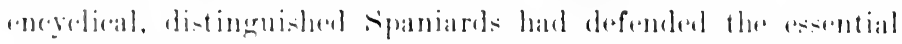
principles of the Aristotelian and Thomistie phitosophy. Inring the (")urse of the ninetenth entury, spatin, as we shall see.

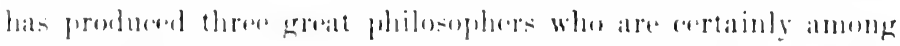

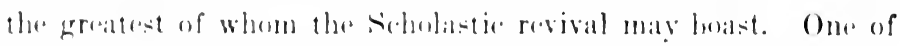
them, Irraburu, is still living: the wher two, Balmes and fonkalle, hase departed from this world many gears ago, hut their workin are immortal.

It the and of the eighterenth antury, the sensiom of tocke" and comdillate was introfuced into spain and gained many dis-

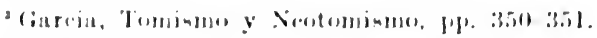

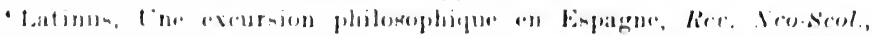
1901. 11. 191241 . 
ciples. Among its best known adherents may be mentioned the Jesuits Eximeno and Andres. Scholasticism, however, did not disappear altogether. It was defended by Rafael Puigecrver, O.P., in his Philosophia Sancti Thomce Aquinatis, auribus hujus temporis accommodata, which was used as a text-book in many institutions.

Not long afterwards, Francisco Alvarado, O.P. (1756-1814), generally known as "el filósofo rancio" (the rank philosopher), acquired a great celebrity by his Cartas Aristotélicas and his Cartas Criticas, in which he defended the philosophy of St. Thomas against the heterodox, political, social and philosophical theories which had been recently introduced into Spain.

But the man who gave to Spanish philosophy its greatest splendor during the first half of the nineteenth century was undoubtedly Balmes.

James Balmes was born in Vich (Catalonia) in 1810 and died in 1848. Completely unknown in 1840, he acquired in a few years an inmense reputation. He alone succeeded in awakening the interest of Europe in Spanish thought. Besides numerous social productions, among which must be mentioned a comparative study of Protestantism and Catholicism with regard to their influence upon European civilization, Balmes has written the following philosophical works: El Criterio, or a study of the criteria of truth, which, in Mr. Turner's opinion, is his most valuable contribution to philosophy: Cartas á un escéptico, a collection of letters in which scepticism is most ably discussed; Filosofía clemental; and Filosofia fundamental, the work upon which his fame as a philosopher chiefly rests.

Orestes A. Brownson declares the Fundamental Philosophy to be not only Balmes's masterpiece, but the most important work published on the bases of philosophy during the nineteenth century.5 This judgment is too eulogistic perhaps; but we must at least admit that Balmes's work has acquired the charac-

"Balmes, Fundamental Philosophy, New York, 1903: Brownson's Int roduction, p. viii. 
tor of a phitomphical aresice and will be studied at long as

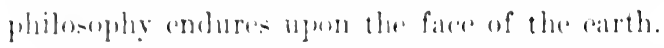

When Balmes wrote his works there were ats yet no signs of a return to Thomi-m. His philusophy, aceordingly, is not directy connectent with the neo-scholastic revival. It is how-

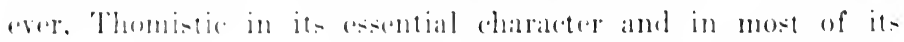
details. Themale Aguinats was the faverite author of the spani.h thinker, whe regrarded the siumme Theologied as the fountain of all truth. Balmes thought hats also been intlatenceid.

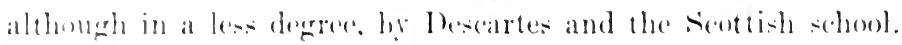

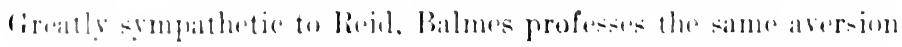

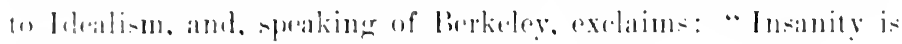
in-anity still. heweser suhlime it may lu. ${ }^{\circ}$

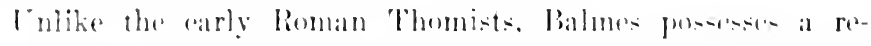
markable knowlentere of molern philosophe. Ho knows thoromghly Ihesarter. Lonke. Condillace. Hume. Lamennais, and his

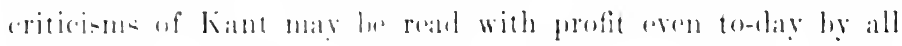

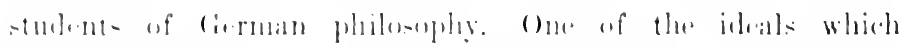
Balmes ebri-hed. and which a premature death did not allow him we ralize, was a thorough study and a refutation of (iorman julealiem, stranger to sily. Balme is. howerer. less far from

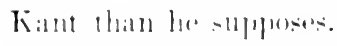

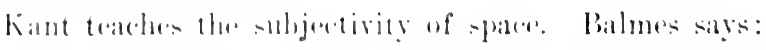

"The ideat of extention is a primitive fanet of our mind. It is not prenduced he sensitions, but precedse them, if not in time. at leat in the oriter of being."

Kant teaches that our knewlenlye of the external world is mothing hat a knowledge of phenomena, and that the thing-initolf is unknowathe. Balmos sats:

"I pure spirit-the existence of which we must alwals supfere: for, thengh all finite lu.inge were annihilated, there would still remain the infinite buing which is (iont-at pure spirit would

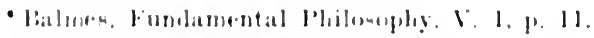

' ll, 1. 1. 1. 317. 
know the extended world just as it is in itself, and would not have the sensible representations either external or internal which we have."8

Kant teaches that, even with regard to our own self, our knowledge is phenomenal. Balmes says:

"The Ego does not see itself intuitively; it is offered to itself only mediately, by its acts; that is, so far as it is known, it is in the same eategory as all other external beings, which are all known by their effect upon us."

A comparative study of the philosophies of Balmes and Kant would be of great interest. The scope of this treatise obliges us to limit ourselves to a suggestion and a few remarks. Whatever the conclusions of such a study might be, one thing is beyond doubt: Balmes's principles show a marked tendency to subjectivism. He professes that we possess certainty only with regard to internal phenomena, and that we know external objects by means of a natural instinct.

Ramon Marti de Eixala (died 185\%), although lacking the depth of genius of Balmes, exercised a more direct influence upon Spanish thinking. Surrounded by a number of disciples, he gave birth to the school known as "Catalonian school." One of his disciples, Llorens, eagerly entered into the spirit of the Thomistic revival which was then taking place in Italy, and, during the last years of his life, strove to put his doctrine in perfect harmony with those of Sanseverino and Cornoldi.

Not long afterwards, the same provinee of Catalonia, proud of such thinkers as Marti and Balmes, produced another philosopher of real merit, Antonio Comellas.

Antonio Comellas y Cluet (1832-1884) has not enjoyed during his life the noisy celebrity in which other men delight. Even after his death, he has remained unknown for many years, and his name would probably be forgotten to-day were it not

Ibid., V. 1, p. 432.

Ibid., V. 1, p. 42. 
for the learned study made by the distinguished historian of philosophy, Ciome Izquierdo, in the review La c'ultura Española (ce. Bibliography). Comellas's life, as (iome\% Izquierdo points out, may be summed up in these two words: Solitude and stud!y.

His greatest contribution to philosophy are his Demonstración de le armonia entre la religuín católica y la ciencia and his Introduccioin a la Pilosofía.

The man who has raised Spanish philosophy to its greatest height during the socond half of the nineteenth century is Cardinal (ionzale\%.

Zuferino (ionzalez y Díaz-Tuñon (1831-1892), born in Villoria, entered the I)ominican order at the age of thirteen and was sent, when quite a young man, to the mission of the Philippines. In Manila, he taught philosophy and thoology and published his first work: Estudios sobre la Filosofia de Santo Tomas, which evinees a deep knowledge of the philosophy of the Angelic Doctor, and is regarded by many crities as the most remarkable work on the subject written during the nineteenth century.

compelled by his health to return to Spain in 186is, Gonzalez contributed to la liudud de llos and other periodicals numerous philosophinal essays. His l'hilosophia elementaria, his Estudius religiosos, filosifficos, cientifuos y sociales, his most reent work, La Biblia y la ('iencia (1891), and especially his Mistoria de la Filoswfin. in which a whole volume is devoted to Mediaval philosophy, have given the last touch to his reputation ats a philosopher and ascured him a place among the greatest thinkers of his country and the most genuine defenders and propagators of neo-sedholasticism.

('otemprancous with (ionzalez are Orti y Lara and Pidaly Mon.

Juan Manuel Orti y Iara has written immensely. His most important philwenhial works may he seen in our bibliography.

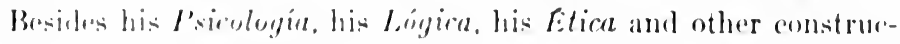
tive works. he dinerser the gratitude of neo-sicholastics for his 
refutation of the pantheistic philosophy of Krause and of the work of Draper. His conception of the Thomistic movement is, however, very narrow. Orti y Lara does not take any interest in modern philosophy, which he regards as "resting upon error and sin."10

Alejandro Pidal y Mon, born in Madrid in 184\%, is chiefly known as a political writer. His principal contributions to philosophy are a work entitled Sistemas filosóficos (1873), and a study on St. Thomas, Santo Tomás de Aquino (1875), which has been greatly praised by Cardinal Gonzalez.

Among the most recent Spanish neo-Seholastics, let us mention: Arnaiz, Cepeda, Daurella, Donadiu, Gonzalez y Arintero, Lemos, Ilernández y Fajarnés, Miralles y Sbert, the Jesuits Urráburu and Mendive, the historian of philosophy Gómez Izquierdo.

J. Mendive, S.J. (died 1906), is the author of a course of philosophy, written at first in Spanish, and afterwards published in Latin (1886). Like many other Jesuits, he has been reproached with following Suarez too closely in his interpretations of St. Thomas.

Antonio Hernandez y Fajarnés, professor in the University of Zaragoza, is the author of a series of philosophical and scientific works in which the fundamental principles of Scholasticism are defended and opposed to the antagonistic modern theories. His first work, Psicología celular (1884), is an able refutation of Haeckel's biological theories. His Ontología (188r) is dirceted against positivism.

Juan Gonzalez de Arintero, O.P., published in 1904 a work entitled La Providencia y la Evolución, whose chief aim is the proof of the existence of finality in the universe. Fr. Arintero attacks the doctrine of pure chance; and, in his chapter on evolution, elearly shows that evolution without finality is contrary to reason, to experience, to seience itself.

${ }^{10}$ ('f. Latinus, Une excursion philosophique en Espagne, Rev. NeoS'col., 1901. 
So les profomml is the selentific knowledge of Placido Angel lemos. In his work. La Vida ()rganica, publi-hed in 190\%, he defends the validity of the concept of substanee proves against Hackel the muity of the living heing. studies the origin of life upon the atrth, and -trives to show that a perfect harmemy exists between scientitie diserveries and the teachings of the Bible.

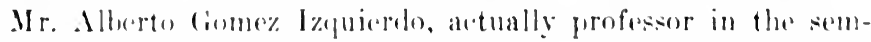
inary of Kalagoza, has contributed to the lierista de Aragin and the c'ulture Española numerous articles in which he has rentilated intreresting questions concerning the history of philosophy. Ho has also published a M istory of I'hilosophy in the II.I century. which is one of the most important and best documented works we possess on the subject. Mr. Gomez has entirely omittul stranish philosophy from his History, but he has promised a separate volume on the subject, which all whe are interested in philosophical researehes expect with feverish eagerness.

John .Joseph l rraburm, s..J. published in lson eight hig Iatin quarto volumes with the title Institutiones Jhilosophice. The first deals with logre, the serond with ontologry, the third with cosmolenge, the next three with Psechologrs the last wo with Ditural 'Theolegrs.

Some gears afterwards. he exposed his teachinges anew in a more conceise form, and puhlished a compendium Jhilosophiop scholastier which, in spite of its modert title, consists of no less than five large octabo volumes.

Fr. Irriburus works comstitute a monumental production,

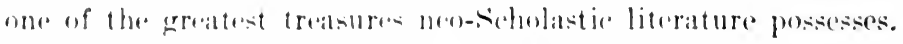

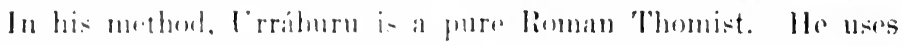
the Jatin langmage, the syllegistic form, and proves the truth of his toachinge from the authority of the church and the livine Revelation as often and as willingly as by human reason. H. differs from many Roman Thomists hy his knowledere of modern sebutife results. The andusions he derives from these results are not always justifiable, hut his knowledge of the scientific facts themselves annot be denied. 
Urráburu's works-perhaps on account of the very method they follow-have not attracted the attention they deserve. Their author's name is not even mentioned in Mr. Blane's Dictionnaire de Philosophie, published in 1906. The actual current of neo-Scholasticism, chiefly due to the influence of Mgr. Mercier and the Institute of Louvain, is unfavorable to Urríburu. It professes that the Latin language ought to be discarded in philosophical discussions, and that philosophy ought to be regarded as a science which must go its own way, without any predeterminate conclusion imposed by theological beliefs. To the objection that this has not been the method followed by St. Thomas, the Scholastics of Louvain would answer that St. Thomas acted in harmony with the spirit of his time, and that, if he lived now, he would likewise act in harmony with the spirit and methods of our day. This may be very true, but it proves too much. If St. Thomas lived to-day, a Positivist might ask, if he breathed in our intellectual atmosphere, would he be a Dominican? Would he be a Scholastic?

Urráburu's method is perhaps, on the whole, more consistent with the principles of Scholasticism than his opponents' view. The Scholastics of Louvain are as profoundly convinced of the truth of the doctrines of the Church as Urráburu is. They believe as strongly as the eminent Spaniard that a philosophical or a scientific conclusion opposed to the revealed truths is erroneous and must be rejected. If such be the ease, and if the primary aim of philosophy be the attainment of truth, is it not illogical to abstain from taking theological doctrines as a guide in philosophical investigations?

A proof from Scripture will not appeal to the modern mind. In Protestant countries especially it will sound as profoundly unphilosophical. But we must not forget that Urráburu writes in a Catholic country and for Catholic readers. The spirit of free interpretation has led Protestant theology very far. Many Protestant ministers to-day doubt the existence of hell, and a few are inclined to transform a personal God into an ethical or 
metaphysal principle. The ease of the ('atholic clergy is quite ditferent. All whe are really ('atholices firmly believe, not only in a personal fiod, who sees us and watehes over us, in a hell in which the reprobate will he tortured with the devils during the whole eternity, huteren in the Immaculate conception and the infallibility of the pope.

It eamnet be dented that the spirit of Louvain is more in harmony with modern thought. This is the reason why the works: published hy the Institut Superieur de Philosophie have been translated into various languages and have attracted the attention of all Europe, whereas Irráburu's bulky volumes have been forgotten in some dusty corner of a conventual library. 'The study of the works of the learned Jesuit is, however, indispensiab. for an adequate understanding of the spirit of Scholaticiom.

Let us not lave spain without mentioning some important reviews which have gratly helped the callse of neo-'Thomism. lidzin y F'. La ('iudad de l)ios, the lievista de Aragon, and the

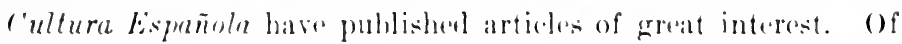
greater interest still is the Rerista Luliena, founded in BarcoIona in 1901, and whose aim is the publieation and the critical interpretation of the works of the Mediaval spanish philnsopher Raymond Lully.

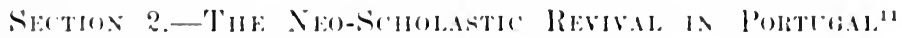

'lhe march of philosophy in Portugal is elosely connected with that of philosophy in spain. Buth countries hase been inspired hy the same masters, and have followed parallel direse-

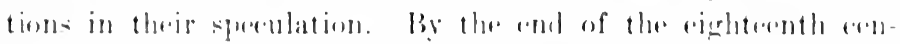
tury, the dominant system in Portuguese institutions was a

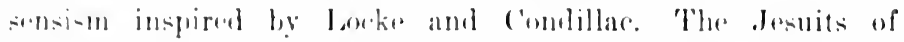
coimbra, who alone elung to an orthodox Thomism, were sewerly attacked by other religions orders, especially by the (Oratorians and Augustinians. ('ondillaces Art de l'enser war

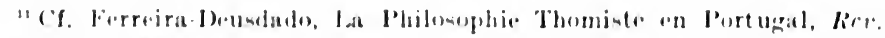
lesoscol., lasis. 
translated into Portuguese and published in 1818. The Oratorian Fr. John the Baptist, the archdeacon Luiz Antonio Verney and Theodoro d'Almeida frankly introduced modern systems of thought into the Portuguese philosophical circles.

Little was done in Portugal for a restoration of Thomism before the publication of Leo XIII's encyelical. The few contributions to Scholastic literature written in Portuguese during that period, do not belong to Portugal proper, but to Asia or America.

In Macao, the Jesuit Francis X. Rondina (182\%-189\%), an Italian by birth, published in 1869 a course of philosophy in harmony with the Scholastic principles. The title of the work is: Compendio de Philosophia theoretica e pratica para uso da mocidade portuguesa na China. The author has been directly inspired by St. Thomas, Suarez, Goudin, Balmes, Gonzalez, and, to a certain extent, by Rosmini.

Two years later, Jose Soriano de Sousa, professor in Pernambuco (Brazil), published his Licões de Philosophia elementar racional e moral, perfectly Thomistic in spirit, which he dedicated to Emperor Pedro II.

After the promulgation of the encyclical Eterni Patris, the Catholics of Portugal entered without hesitation into the spirit of the Roman Pontiff. By the philosophical academies they founded, the reviews and the works they published, they have assured to their country a conspicuous place in the history of neo-'Thomism.

In 1881, an Academy of St. Thomas was founded in Coimbra, and, by means of its organ, the review Institucoes christas, actively contributed to turn the attention of Portugal to the Thomistic revival. The foundation of the lcademy of St. Thomas was soon followed by the publication of philosophical works inspired by Scholastic principles. Among the writers who thus served the cause of neo-Scholasticism, the best known are Sinibaldi, Pereira Gomez de Carvalho and Madureira.

Thiago Sinibaldi, professor in the seminary of Coimbra, pub- 
lished in an! his I'rolertiones I'hilosophier christioner, and,

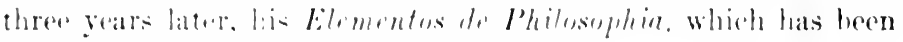
homored hy several enditions.

C'lement l'rereira liome\% de l'arvalho, profecoror in the ('entral

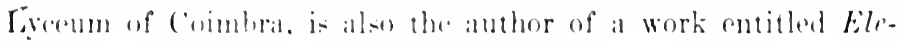
montes de l'hilasephin, which was published in 1 s.9.

Bermarde Augnato de Madureira, professor in the Faculty of 'Theolegy of the leniversity of combra, published, in 1sit, at furem entitlel, () sol didumo, which deals with the lifo and the phiberphy of the Anerelic looctor, and was dedicatod ly the author to the new-born Arakemy of st. Thomas. Sime that time. Mr. Madureira has also published a manual of klamentary Philosophy (1896).

Another aletive supporter of neo-thomi-m in lortugal is Mr. Manmel Jose Martins ('apellal, to whose initiative is due the fotindation of a chair of 'Thomistic philosophy in the seminary of liraga (1sig:)

More recently, Mr. Teixera Lumbes has organized in Simtarem a Philosophical and Literary Academy, whose aim is the ditfusion of the 'Thomistie dextrines among the people. 'The Acatemy has been inangrurated in 1s!ts by the ('ardinal Archbishop) of li-bon.

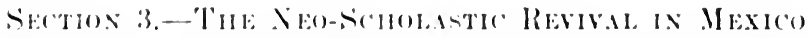

liy the midnle of the nineterenth rentury. Sidholastic philosophy hat pratetially di-appeared from the Mexican soil. Fien catholies regarded with the groatest disceperet a slstrm which, in previons conturies, had been defonded in Mexico by so many illustroms thinkers. From August, 1stis, to May, 18ta, there

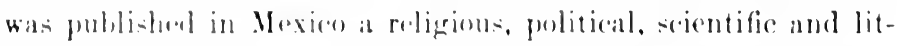

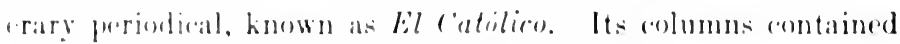
mumerous articles doaling with llistory of Philosophy. aperebally with sehulaticism. 'These articles were published anonymonsly, hut it apjears from the works of the reminent historian 
Valverde Tellez that they were due to the pen of the Jesuit Arrillaga. ${ }^{12}$

Arrillaga defines Scholasticism in terms of its method of exposition, gives a cold praise to Abelard and Thomas Aquinas, calling them "rare geniuses who, in another time, could have done wonders," is particularly severe towards Duns Scotus. speaks of Lully's Ars magna as of a collection of extravagances. Similar views were current at the time. The greatest Catholic thinker Mexico has produced, Clemente de Jesus Munguía, does not absolutely escape them. After exposing the Scholastic doctrine about the origin of ideas, the distinguished bishop finds himself at a loss to explain how "such an absurd theory could enjoy so great a vogue, and for so long a time, among philosophers."'13

The philosophical system of Munguia, however, agrees in the main with the principles of the School. He who has been called by his admirers "the Balmes of Mexico" may be regarded with justice as one of the forerunners of the neo-Scholastic movement in his country. Our bibliography contains the titles of his most important philosophical publications.

The first man who, by his writings and his influence, directly contributed to the revival of Thomism in Mexico is Bishop Sollano.

José María de Jesús Diez de Sollano y Dávalos was born in San Miguel de Allende (Guanajuato) in 1820. After studying in his native town and in Mexico, he was ordained priest in 1844, and became successively rector of the College of San Gregorio, of the Seminary and of the University. In 1863 he was made bishop of Leon by Pius IX. He died in 1881 .

The philosophical writings of Bishop Sollano are not of great importance. They are limited to an annotated edition of Roux's Logic, a pastoral letter dealing with the encyclical Riterni

${ }^{12}$ Cf. Valverde Tellez, Bibliografía Filosófica Mexicana, p. 41.

${ }^{13} \mathrm{Cf}$. Valverde Tellez, Apuntaciones históricas de la Filosofía en Mexico, p. 262. 
I'atris, and a dissertation ahout the Immaculate Conception. Cevertheless, Sollano must be regarded as one of the liest propagators of neo-sidulasticiom in Mexico, on account of the influence he expreised upon the direction of philosophy in making of his seminary of leon one of the most active centers of neoThomism.

from all parts of the Mexican republic there soon arose distinguished writers to defend the esential principles of sicholat:tir philosophy, so that the neo-sicholastic movement in Mexien can compare without too mueh disadrantage with the same movement in Enropean nations.

Agustin de la losa (born 1s:24), canon of (inadalajara, d.fended the siblabtite doctrine of truth in his ('onsideraciones filosificas solure la Verdad y la Certilumber (1850).

Jose M. de Jesus Portugal, hishop of Aguascalientes, wrote. with the titles of El Amalle Jesus and La sianta roluntad de Dios, exeellent eommentaries on the works of st. Thomas. E' Amable Jesus is a commentary on the third part of the summa Theologica, whereas La santa Voluntad de Itos deals with the. Summa contra ciontiles.

Agustin F. Villa greatly facilitated the study of Scholastic philosophy by the publication of a Vocabulary of Scholastic Terms $(18 \% 9)$.

Nicanor Lozala published in 1880 his A puntes de Lógion. l'osmologia y l'sicologin. This work is not a course of Scholastic philosophy. As its title indicates, it simply consists of notes and observations destined to give to the students a clear intelligence of some obsere points of the text-book they were using. This text-book was (irandelaude's Breviarium l'hilosophiur schollasticer.

Rafant ('agrigas (186it-1sen), whose premature death has buen a wreat lose to Mrexiean philosophieal literature, manifests an "nthusiastic almiration for the Thomistic doctrine, in his volume of works published in 1890 . With the soul of a pret. the soung writer studies the most abstruse philosophical doc- 
trincs. The theory of Matter and Form is for him a boundless harmony, which he sees reflected in the human mind. Cagigas is perhaps too severe for modern philosophy, as may be gathered from the following fragment of a spech he pronounced in the Catholic Circle of Mexico, on January 19, 1890 :

"Modern philosophy, from Deseartes to this day, is in a state of evident decay. She declares it herself with furious cries, appearing to the eyes of the crowd as a collection of all errors, as a sink of all filth, as the ruin of all spirits, as a labyrinth where the wisest man himself is suddenly confounded. What is morality in the cathedras, in the societies such a pliilosophy corrupts? The negative morality of the mule and of the ass." 14

Secundino Briceño, besides an opuscule on the syllogism and a dissertation dealing with St. Thomas's doctrine about the Immaculate Conception, has written a comparative study of the Spencerian and Scholastic philosophy. The title of this work is Ligeros A puntes sobre la Filosofía de Spencer comparada con la Filosofía Escolástica. Its aim is to oppose the powerful current of positivism which, due to the influence of Barreda and Porfirio Parra, has been for a long time the official philosophy in Mexico. Briceño limits his considerations to Spencer's First Principles, and skilfully points out the contradictions contained in the doctrine of the English philosopher.

An able representative of neo-Scholasticism in Mexico is the Dominican Guillermo García. A Spaniard by birth, now professor of dogmatic theology in the seminary of San Luis Potosí, Fr. García has written, besides a pamphlet on St. Bonaventure, a historical study entitled Tomismo y Ncotomismo. The aim of this treatise is to give a full account of the works and the philosophical doctrines of Thomas Aquinas, to compare his philosophy with the modern currents of thought, to give a historical survey of the Thomistic philosophy throughout the ages. The part of the work dealing with modern philosophical systems has not much value. It is easy to see that Fr. García is not

${ }^{14}$ In Obras de R. Cagigas, pp. $176 \mathrm{ff}$. Also given in Valverde's Apuntaciones, p. $402 \mathrm{fr}$. 
preciscly at home when he deals with Locke, Kant, Fichte and Hegel. His knowledge of st. Thomats, on the other hand, is certainly thorough. Mis almiration for the Angelic loctor is

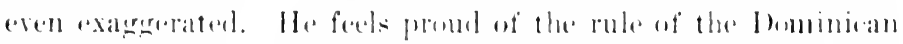
order, which ammands to follow st. Thomals in every point. in emmiluse. emmine. under the most serere penalties, obliges to a bow of fidelity to his doetrines. and regarels als impouss the slightert deviation from them."

Xuw, such a rube is not only unphilosophical. hut anti'Thomistice. 'There is nothing more oppeserel to the spirit of a philosepher than a systematic and muritical allherence to each frepestion he has maintained. Philosophy is essentially a thinking study of things. Wr must arefully meditate the works of our prederessors. we must try to understand their meaning, to grasp their train of thomght, but we are philosophers only in se far as we think with our own head. All great thinkers have studied the various philosophical systems. hut they have not servilely allhered to them. 'They hase marked threir works with the seal of their own individuality. sit. Thomatis is no exerption to this rule.

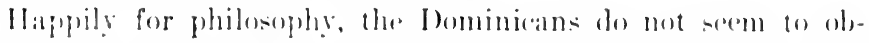
serve very strictly the rule of which Fre Garcia is so proud. stramge to sil (iarcia himself furnishes us ample prowf of this: assertion. I sertion of Tomismo y Sertomismo is devotod to

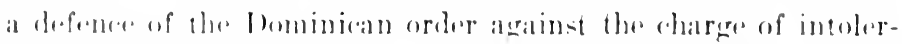
ance. Tlar anther gives the names of notable members of the order who have more or less departed from st. Thomas's teatehing withrout heing molesed. He speaks of Thomats do Vio ('ajotamus, of Ambroso latarino, of 'Thomats C'ampanellat, and

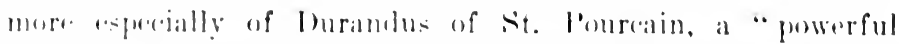

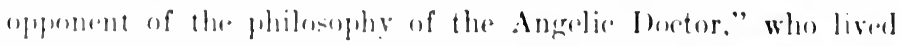
amd tied in the Dominican order without ever suffering the slighte-it peracention. ${ }^{10}$

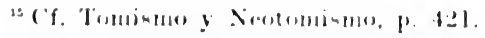

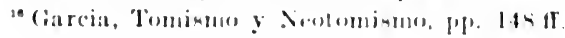


This is not the only contradiction which Tomismo y Neotomismo contains. Fr. García's position as regards neo-Scholasticism is far from being clcar. He declares that his view of the Thomistic movement is in harmony with the view of the Louvain school, and he gives an excellent program of neo-Scholasticism to which every professor of Louvain would subscribe. On the other hand, he quotes with approval Cornoldi's famous phrase describing modern philosophy as the pathology of human reason, and cannot blame Orti y Lara for regarding modern thought as resting upon error and sin.

In spite of these defects, Tomismo $y$ Neotomismo is a valuable little work. It contains important historical data about the Thomistic movement. The five chapters dealing with the philosophy of St. Thomas in the Dominican order are particularly interesting. Fr. García is actually preparing a treatise on St. 'Thomas's sociology. We sincerely hope that this new work will be, like Tomismo y Neotomismo, a precious contribution to neoScholastic literature.

No Mexican, however, deserves the thanks of all lovers of Scholastic philosophy so greatly as Mr. Valverde Tellez.

Emeterio Valverde Tellez, a canon of the cathedral of Mexico, has written, besides a treatise on truth, three historical works of great importance: the A puntaciones históricas sobre la Filosofía en México (1896); the Critica Filosófica (1904); and the Bibliografía Filosófica Mexicana (1907).

In the Apuntaciones históricas, Mr. Valverde, after general considerations on the nature of philosophy and a weak defense of Metaphysics against the attacks of Positivism, traces the great lines of Mexican speculation, gives valuable informations about the libraries and the centers of learning in Mexico, leads us through the vicissitudes of the Mexican University since its foundation in 1521 to its final suppression in 1868, and the foundation of the new Pontifical University in 1896. He then passes to a detailed and critical study of the various philosoph- 
ical systems in his country. He analyzes the works and the doctrines of all great Mexican thinkers.

In spite of his enthusiastic admiration for St. Thomas, Mr. Valverle does full justice to the philosophers of other schools. His study of the recent positivistic movement in Mexico and of the violent discussions to which it has given rise is excellent. ${ }^{17}$

The ('ritica Filosifica completes the 1 puntaciones by furnishing new data, by making us know philosophical works completely unknown, and unearthed by the patient labor of the author.

The Bibliografia Filssifica Mericana gives ns, with the greatest ractitude, the list of all philosophical productions written in Mexico. Each work is preceded by a biographical sketch of its author and followed by a critical analysis, so that the Bibliografia is indispensable to all who are interested in the march of philosophical speculation among the Spanish race.

\section{Section 4-Dhe Neo-scholastio Revival in Solth AMFRICA}

Among the countries which have eagerly embraced the cause of the Soholastic revival, Colombia deserves a special attention. Thomism has become, as it were, its oflicial philosophy, and, more than anywhere else perhaps, has identified itself with the spirit of the nation.

When, in the middle of the last century, Benthams utilitarian ethieal sytem was introduced into colombia, it was opposed b: some of the most eminent Colombian writers. Margallo, M.M. Mallarino, Ricardo de la Parra. Joaquin Mosquera, Mario Valenzuela, and more epeecially Joé Eusebio ('aro (1817-1853) and his illustrous on, Miguel Antonio caro, defended the 'Thomistir meral stitem with much ability and sucess.

Miguel Intonio ('aro, born in Bogentá on November 10, 18.43, is chiefly known as a politician and a man of letters. As a politician, he hats axreised an immense infuence upon the gor-

\footnotetext{
"The greatent supporter of Positiviom in Mexion is Mr. Porfirio Parra. Ite mont irmoducible adverwary has been Mr. I. M. Vigil.
} 
ernment of his country, and has been intrusted with the high office of president. Among his literary achievements, which have given him a conspicuous place in the history of Spanish literature, let us mention his admirable translation of Virgil into Spanish verse. His most lasting title to the gratitude of Philosophy is his Estudio sobre el Utilitarismo, which has been proclaimed worthy of Joseph de Maistre. ${ }^{1 \mathrm{~s}}$

The most important center of Thomism in Colombia is actually the College of the Rosary (Colegio Mayor de Nuestra Señora del Rosario) in Bogota.

As early as 1881, Rafael Maria Carrasquilla (born in Bogota on December 18, 185\%, and president of the College of the Rosary sinee 1891) proclaimed his artherence to the philosophy imposed by Pope Leo XIII on the Catholic world. "To the modern errors," said he, "we must oppose the entire truth, even if we offend the pride of our century of progress, by exhibiting a monk of the thirteenth century as a model of wisdom." 19

The program thus sketehed by Mr. Carrasquilla has been faithfully carried out. All the works and essays the College has produced have been inspired by the purest Thomistic principles, so that the history of the College of the Rosary during the last fifteen years forms one of the most interesting pages of a history of neo-Scholasticism.

The adherence of the college to the principles of the Angelic Doctor does not, however, degenerate into servility. It is essentially eelectic and progressive. The new constitutions of the college strongly insist upon the fact that we must follow the Scholastics wherever their philosophy is acceptable in the light of modern criticism, and reject their doctrines if they have proved erroneous or inadequate. ${ }^{20}$

The most important work of Mr. Carrasquilla is the volume entitled, Ensayo sobre la doctrina liberal, which has obtained

18 ('f. Ramirez, Filosofia Positivista, p. 95.

${ }^{10}$ Carrasquilla. Sobre el estudio de la filosofia; Repert. Colomb., Aug., 1881.

${ }^{\circ}$ Cf. Revista del Colegio del Rosario, June, 1906, p. 316. 
him the homer of heing described as a "republican Balmes."

By its title. the linsuyo sobre la Doctrina Liberal seems to belong to political selence rather than to philosophy. It is as

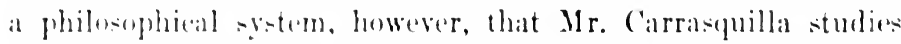
liberalim, which he refutes by the Thomistic social principles. "Liberalism," sals he, "is abose all a philosophieal school, which a priest may study and refute with the same right wherewith h. would combat Descartes. Hegel or Rosmini."

Among the men who have contributed to give to the colleges of the Rosary the Themistic direetion it has to-day, none is more conspicuous than Mr. Julian Restrepo Iternínde\% professor of logite and anthropology in the college since $189 \%$.

Born in Bogotí on July 2:3, 1si 1, Julian Restrepo Herninde\% studied in the College of the Rosiry and showed such philosophical ateumen that he wats placed in the chair of logie in 1890 . while still at student in the college. Later on, he studied law and wrote for the ('olombian government the C'odificarion C'undinamaryuesa. which contains the entire lecristation of colombia. and forms a volume of 1208 pages folio.

Mr. Liestrepo, however, hats not neglected philesophy and has recently (1900) published a volume on logie (Lecriones de loigien, in which he has emberied the lectures given to the stuHents of the college of the liesary.

'The qualities which distinguish this work has heen wery skilfully peinted ont he the distinguished literary artic liufino dose cuerve in al peromal letter to the author: "The pleasure I experinened at the reading of your volume on Logies alys Mr. curro. comes thiefly from the elearness, precision and rigorous methend of the work, in which aneient and motern learning are combined, se that truth may apluar more luminous and attratepise."

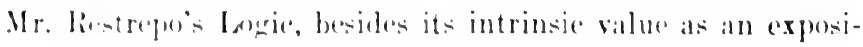

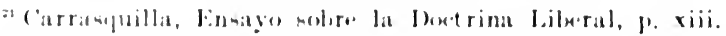

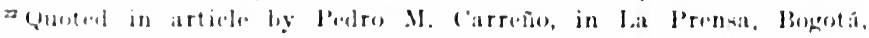
leed $14,190 \%$. 
tion of the Scholastic logical principles, is worthy of attention for a theory of the modes of the hypothetical syllogism, which constitutes a direct contribution of the author to the field of logic.

Since 1905, the College of the Rosary also publishes an important review (Revista del Colegio Mayor de Nuestra Señora del Rosario) which is undoubtedly one of the most excellent South American periodical publications. Its field is not confined to philosophy. It treats likewise of literature, education, history, and seldom fails to give a delightful piece of poetry.

From a philosophical point of view, the most important contribution of the review is the essay entitled Santo Tomís ante la ciencia moderna, of Francisco Maria Rengifo, now professor in the college.

Mr. Rengifo studies the modern theories defended by mathematies and seience and shows that they are in perfect harmony with the essential principles of Thomism.

Let us not leave the College of the Rosary without mentioning the interesting work entitled La Filosofia Positivista, written by Samuel Ramirez (1875-1908), as a dissertation for the degree of Doctor of Philosophy. After giving a detailed history of the various positivistic schools, Mr. Ramirez demonstrates the superiority of the Thomistic principles over the doctrines of Comte and his disciples.

The Rev. Luis Ortiz, S.J., professor in the College of San Bartolomé, has contributed to Colombian neo-Scholastic literature a little work entitled La Vida (Life). The thesis defended by the author is the following: "The doctrine of the Angelic Doctor and of Fr. Suarez, defending the existence of a vital prineiple, which informs living beings and is essentially distinct from the physico-chemical forces of brute matter, is confirmed by the observations of modern science; or, more briefly, the physical and chemical forces are inadequate to explain life."

The proofs adduced by Fr. Ortiz in defence of this thesis are 
a derolepment of the following argument: The essences of thing: are known from the operations and properties of these things. The operations and propertics of inoranic matter are esentially different from those which eharaterion living heings. Therefore, the nature of liviner beings is essentially different from that of inneranic matter.

colombia is not the only south American republic in which the spirit of the Thomistie revival has penetrated. The most important contribution of fiouth America to the caluse of neosibulatieism eame from ('hile and was dur to Franciseo Ginebrat, of the simediety of .Jests.

Ginebra: Flementos de Filesofia, published in lssa in santiagen (chile), has desersolly run inte sereral aditions. It is ome of the most valuahle text-hooks on seholastic philosophy which the neosecholastic revival has produced. The author has been rhiofly inspired hy st. Thombls, suarez, Liberatore, KloutEen, cornoldi and balmes.

The filomentos de filosefin is completed by a treation on

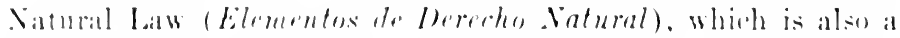
rery important work, and has been alopered as a text-bonk in -r.pral of the somth American sehools of law. 


\section{CHAPTER XI}

THE NEO-SCHOLASTIC REVIVAL IN GERMANY, ACSTRIA AND SWITZERLAND

The philosophical systems of Kant and Hegel exercised a powerful influence upon Catholic philosophy in Germany. Georg Hermes (1775-1831) and Anton Guinther (1783-1863) defended the omnipotence of human reason, and, following Hegel, rejected the distinction between natural and supernatural truths-one of the fundamental tenets of the Catholic Church. Rome condemned their doctrines and placed their writings on the Index, so that their efforts, from a Catholic point of view, were a failure.

A movement of return towards Thomistic philosophy then took place among German Catholic thinkers; so that, when Leo XIII published his encyclical, Catholic Germany eagerly espoused the vicws of the Pontiff.

Among the men who prepared this return to Scholasticism must be mentioned:

Friedrich Schlegel, who, in his History of Ancient and Modern Literature, showed the real merit of Mediæval philosophy.

Möhler and his disciple Staudenmaier, who condemned all forms of rationalism.

Clemens, whose aim was the refutation of Günther.

Rothenflue, who, in spite of some ontologistic and Rosminian ideas, agreed in the main with the philosophy of the School.

But the two philosophers who most actively contributed to the revival of Scholasticism in Germany were Kleutgen and Stöckl.

Joseph Kleutgen, S.J. (1811-1883), published in 1860 his Philosophie der Vorzeit, which has become one of the classical works of neo-Scholastic literature. The Philosophie der Vorzeit 
is not, like Samseverino's Ihilosophia christiuna or Irraburu's Institutiones, a detailed course of scholastic philosophy. It is rather a work of defense. Klentgen is not the peaceful statesman who organizes his country; he is the general on the battle field. His ehief purpose is to purge German (atholic philosophy of all trates of IIegulianism. He vigorously attacks Hermes and ciinther. He defends the Scholastice ronceptions agraint the erroneous interpretations of Frohsehammer, Malebranche and others.

Ho also expounds the fundamental principles of Thomism, and show: that they are the only principles capable of giving entire satisfaction to human reason.

Among kleutgen's contributions to the body of Scholastic dertrines, let us mention his famous principles of knowledge. which have been generally accepted by subsequent neo-Thomists:

1. Knowledge results of the fact that an image of the known oliject is froduced in the knower by the eoncourse of the known object and of the knower.

2 . The known whect is in the knower according to the mode of the knower.

3. Knewledge heemes more perfect in propertion as the knower is more remote. hy the nature of his heing, from material ("onditions..'

Not leng after the publieation of the Philosophie der Vorzet, Allwert stinkl (15:3-1595) wrote his two most important works: Gieschichte der Philesophie des Mittelnters (186t-6i6), and Lehrbuch der Philosolhie. The batter is a dear and valuahle experition of the Themistic philosophy: the former, one of the works which intiated thene historical insestigations about scholastici-m, of which the nineteenth antury is a) lengtimately promil.

The mot important contribution of (irrmany to Sicholastic

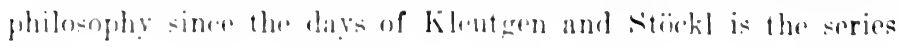

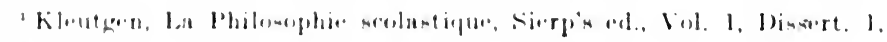
('hap. 1. 
published under the name of Philosophia Lacensis by the Jesuits of Maria-Laach. This series comprises the following works:

Institutiones logicales (3 vol.); Institutiones philosophice naturalis; and Institutiones psychologica, by Tilmann Pesch; Institutiones theodicace sive theologia naturalis, by J. Hontheim ; Institutiones juris naturalis, by 'Th. Meyer; eleven volumes in all, forming a complete course of Scholastic philosophy.

The Philosophia Lacensis is more decidedly Scholastic in its method than any other work neo-Thomism has produced. Fr. Pesch follows in his exposition the same plan St. Thomas followed. Like St. Thomas, he begins with an exposition of adverse doctrines, passes to the thesis containing his own views, ends with an answer to the objections given in the first part.

Such a method must not, however, lead us to believe that the eminent authors of the Philosophia Lacensis are servile followers of the Middle Ages and ignore modern ideas. Their acquaintance with the current of modern philosophy is remarkable. Fr. Pesch discusses all recent seientific hypotheses in his Institutiones Philosophice Naturalis, and tries to establish upon these hypotheses the foundation of Thomistic cosmology. A like knowledge of modern psychology appears in the Institutiones Psychologica.

Fathers Meyer and Hontheim follow the same method and display the same erudition. The latter has recently applied mathematics to logic in his work: Der logische Algoritmus (1895).

Besides Meyer, neo-Scholastic Germany possesses two moralists of a great merit, Costa-Rosetti (1841-1900) and Cathrein.

Victor Cathrein, S.J. (died 1899), published his Moralphilosophie in 1890, and gave it anew in a more concise form a few years afterwards, as one of the rolumes of the series Cursus philosophicus, of which more in the sequel. One of the most important studies contained in Cathrein's work is the chapter dealing with Socialism. Published separately in German, and 
honored by fivenditions in less than two years, it has been translated into English. French, Italian, Polish and Flomish. $\mathrm{Al}$ though the author's conelusions are opposed to the socialistie theeries. Soctialist themsedre have been compelled to admit that he hanl gratepend the esential principles of their syetem more adequately than some of their own followers.

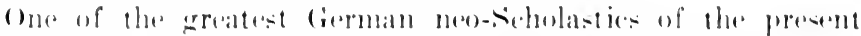
time is Mr. Constantin Gutherlet. profesisor in Fulda s.minary. A. may be seren in our Biblingraphy. Mr. Ciutbrolet has stmdied the themght of the Angelie looctor under all its asperts. Besides mumerous shorter treatises, he published, hetween the

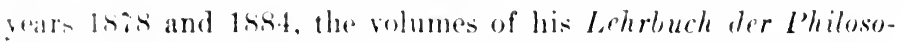
phie. This important work, in which the author generally follows suare\% has been the first gleat sucereful attempt to harmonize modern scienew with l'hemistic principles. Gutberlet's greatest service to the caluse he defends has perhaps been the foundation of the review l'hilosoph iesthes Jahrluch, which, sinces 18st. has laen reald with avility hy all who are interested in the Schelastic revial. Aceording to Mr. Picavet. the Philesophisches Jahrbuel is the most exteretie and the best informed of all nenescholatic periodical publications.

German neostholast ie literature posiseses another review of

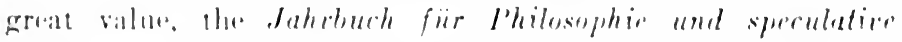

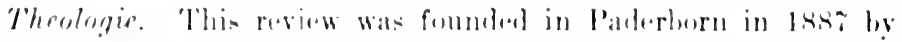
lirnet commer. profesene in the leniversity of Vienms. As its title indirates. it dees mot rontinte itself to philesophieal questions. It often erontains intermeting theoleginal disedesions, and "eperially comparation studies of catholie and Protestant theologre:

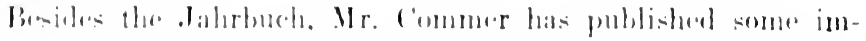

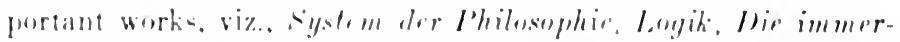
withrende lhileseghie. ete., which hase given him the first rank amone nen-soholaties in Anstria.

I third reviow, the sint-Themesthlatler. published for some 
years in Regensburg by Mr. C. M. Schneider, was more strictly Thomistic than the two other publications we have mentioned. Thomism, according to Mr. Schneider, must be accepted in its entirety or not be accepted at all. This principle inspired the Saint-Thomasblätter, and recurs in all the works Mr. Schneider has published.

Germany has distinguished itself, more than any other nation, by important works concerning the history of philosophy in the Middle Ages. We have already spoken of Albert Stöekl. Not long afterwards, Carl Werner published important monographs dealing with the doctrine of all the great Mediæval thinkers. Alcuin, Albert the Great, William of Auvergne, Roger Bacon, St. Bonaventure, St. Thomas Aquinas, Duns Scotus, Suarez, were studied with untiring zeal and incredible erudition.

Some years later, Ehrle and Henry Denifle, O.P. (died 1905), published the Archiv für Literatur und Kirchengeschichte des Mittelalters, which made known many an unknown text, and enriched neo-Scholastic literature with numerous learned studies. Denifle also wrote a IIistory of the Universities in the Middle Ages, which is the most precious work we possess on the subject. This History gave its author such a fame that the French Academy invited him to write a Chartularium Universitatis Parisiensis, which he completed (1891) with the coöperation of $\mathrm{A}$. Chatelain.

More directly concerned with philosophy than Denifle's contributions are the important works of Clemens Baeumker and Baron G. V. von Hertling, published, since 1891, under the title of Beiträge zur Geschichte der Philosophie des Mittelalters. The collection consists of works heretofore unpublished, critical editions of works already known, monographs, ete. Among the works it already contains let us mention: the De Unitate of Dominicus Gonzalez, falsely attributed to Bocthius, the Fons Vitce of the Jewish philosopher Ibn Gebirol, the Theory of Knowledge of William of Auvergne, the Impossibilia of Siger 
de Brabant, Mr. Grabman's learned study on Cardinal Matthew of Aqualsparta, ete.

Besides this most important contribution to neo-Scholastic literature, Mr. Baeumker has published: I as P'roblem der Materie in der griechischen Philosophie (1890).

In Cirman switzerland, the most important center of neoThomism is the Catholic Iniversity of Friburg, in which the classes of philosophy and theology have been confided to the Dominican Fathers. Among the eminent men who have taught in the university may be mentioned coconnier, Berthier and Mantonnet.

The most distinguished neo-Scholastic in Switzerland is not, however, connected with Friburg Iniversity. It is the Res. Vicolas Kanfmann, president of the Academy of St. Thomas of Lucern. Mr. Kaufmann has contributed numerous articles to the lierue Meosscoldstique, the Philosoph isches Jahrbuch, and several Swiss perioflicals, and has published many valuable works dealing with particular aspects of the philosophy of Aristotle and Thomas Aquinas (cf. Bibliography). One of the best known is his study on Final ('anse, which has been translated into French. In artieles published in the schueizerische hirchenzritung, especially in the article entitled: Das Pontificat Lers. III und der Neuthomismus, Kaufmann has shown that his view of the neo-Thomistic movement is identical with the view of In XIII, and may be expresed hy the famous formula: refera notis augrer.

A complete history of neo-scholasticiom in (ierman-speaking countries would be very extensive. Our rapid survey, incomplete though it be, must not omit the names of the following distinguished men:

Mathias Sichneid (1840-1895) who, besides a work on the influenow of Aristotle upon the Sicholastics, Aristoteles in der scholdstite published in 18 s.t, and inspired by Talano's work

"The werke belonging to this collection are indiented in our Bibling. raphy hy the word libitrighe. 
on the same subject, has written valuable studies on the cosmological theories of Thomas Aquinas and Duns Scotus.

Ludwig Schütz (1838-1901), whose most important contribution to neo-Scholastie literature is a vocabulary known as Thomas-Lexicon, in which all scientific terms contained in the Summa Theologica and the Summa contra Gentiles are thoroughly explained.

Francis Xavier Pfeifer (1829-1902), who has tried to harmonize the Thomistic philosophy with the reeent scientific hypotheses in his work IIarmonische Beziehung zwischen Scholastik und moderner Naturuissenschaft.

Otto Willmann, professor in the University of Prague, and author of a remarkable IIistory of Idealism.

Joseph Jungmann, S.J., the author of one of the best works dealing with estheties (Esthetik, Freiburg, 1884), in which he finds in Scholastic psychology the foundation of the notion of the beautiful.

Francis Schaub, the author of a comparative study of the Thomistic and socialistic theories.

Eugene Rolfes, who has compared the theistic conceptions of St. Thomas and Aristotle, and has tried to discover in the Greek philosopher some traces of the Christian dogmas.

Gundisalv. Feldner, who has published a study about St. Thomas's teaching concerning free will.

Michacl Glossner, eanon of Münich, one of the best known contributors to the Jahrbuch für Philosophie und speculative Theologie.

Martin Grabmann, who, besides the learned study on Matthew of Aquasparta we have already mentioned, has published an excellent treatise on the idea of God in St. Thomas's philosophy. 


\section{('HAP'TER XII}

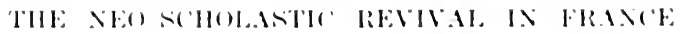

Dlthomeh France eontrihuted perhaps more than any other nation te turn the attention of the world to the Midelle. Ages. the direet rerrent of the 'Themistic revival hat at first little or

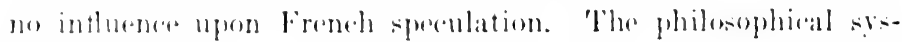
tems of Hescartes and ('omsin were deeply rooted upon the French soll. Even in ('atholie seminaries, the doctrines of the two great Fronch philosophers were oflecially tallght. The textleok most in nse at the time, and whose paeges breathe a strong ('artesian spirit, hat leen writen by Father Valla in the last vears of the preceding century, and was generally known as l'hileseghie de loyne. 'The full title of the work is: Institu-

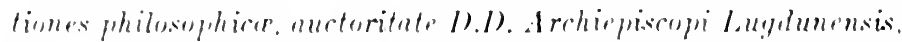
lase. Even after the promulgation of the encycelioal . Eterni

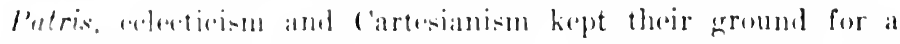
long time among Fromeh ('atholics. This atsily explains how France hall net a single great represontative of neo-seholastieism at the time firmany andel mention with pride the works of Kloutgen: Sipain, those of cardinal com\%alo\%: Italy, those of samseverino, Liburatore and 'Talamo.

The works pmblishere in Franew in defonse of Sidholasticism

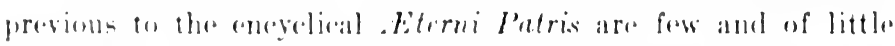
impertanes. Iat us montion the P'rima l'rincipia scientiurum

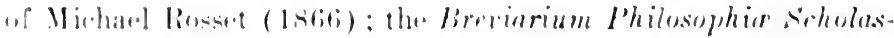

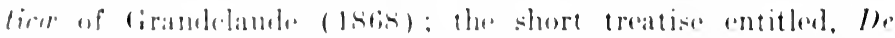

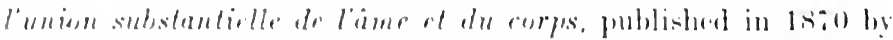
llenri sause, president of the latholie lenversity of Angers:

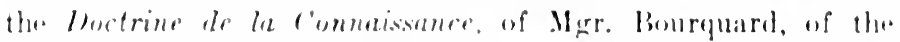
same moniversity published seven years later: and the treatise 
De intellectualismo of the Sulpician P.M. Brin (1843-1894), which has served as a basis to Farges and Barbedette for the Manual of Scholastic philosophy they have recently written (Philosophia scholastica ad mentem Sancti Thoma Aquinatis exposita).

These modest efforts did not fall upon a barren ground. The work of the first pioneers was completed by eminent followers, so that to-day France is second to no other nation in the number and worth of the productions wherewith neo-Scholastic literature has been enriched.

As early as 1875 , Count Domet de Vorges wrote his Métaphysique en présence des sciences, a small work in which the eminent author already evinces a tendency which characterizes his subsequent writings, namely the attempt to show the harmony existing between Aristotelian metaphysics and scientific results.

Mr. Domet de Vorges is one of the most distinguished representatives of neo-Scholasticism in France. For more than thirty years he has defended, with unflagging energy, the great cause of which, so early in life, he proclaimed himself a champion. In union with Mgr. d'Hulst, he founded the Parisian Society of St. Thomas. He has published many important works, and has been one of the most assiduous collaborators of some Catholic reviews, especially of the Annales de Philosophie chrétienne and the Revue de Philosophie. His most valuable productions are his Lssai de Métaphysique positive (1883), in which he professes that Aristotelian metaphysics is a true science, and, like all other sciences, is founded upon the facts of experience; and his Abrégé de Métaphysique (1906), especially interesting for the method it follows. For each problem, Mr. de Vorges brings all solutions proposed by Mediæval philosophers. After a learned comparison and discussion, he gives his preference to one of them or proposes a solution of his own. This historical method cannot be too much praised. It brings 
before our eses the whole boly of sholastic philosophy. It makes us enter into the very spirit of the Midlle Ages.

Among the varly defenders of neo-Thomiom in France, we munt aloo mention the sulpician P. Vallet. His Pralectiones

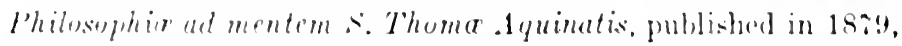
has leen tramslated into sereral languages and homored by numerous editions. Mr. Vallet has also written numerous sherer treation (cf. Bihliegraphy), which have assured him a

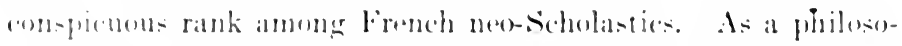
pher he is however, greatly surpassed by another sulpician. Mr. Mlluert Fargens.

Farges greatest contribution to neo-scholatic literature consist of a erites of works published under the title of Etude's Ihilosophiques. The series comprises the following troatises: I. Therorie fondamentale de l'acte et de la puissunce, du moteur

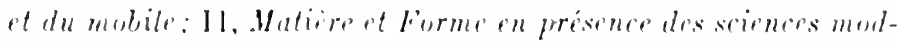

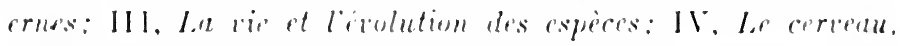

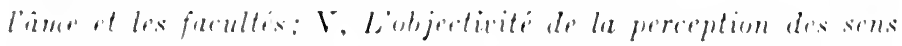
esternes et les theories molernes: V1, Lidte de continu dans

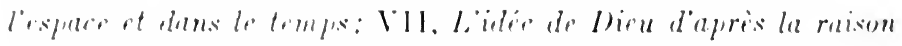

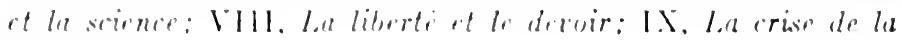
itrtitule.

In these works .1r. Farges expoumds and defonds the fundamental principlen of sideolatide philesophy. He does not fear (1) put Mediand theries in close contact with the most recent

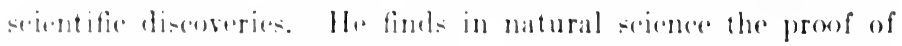
the ductrine of Matter and Form. His conclusions als regatrds

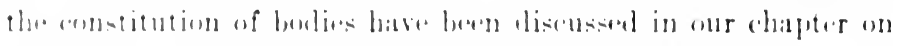

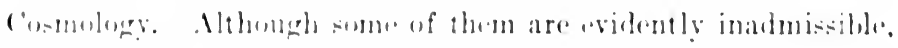

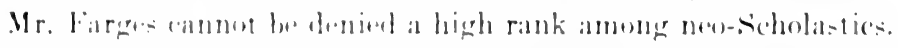

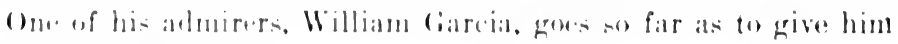
the very firt place.

I third sulpirian, li. Bulliat, les known than Vallet and

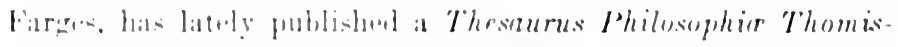

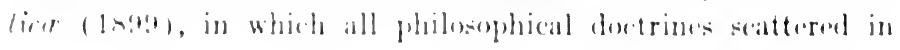


the works of St. Thomas are brought together. The work exclusively consists of extracts from the writings of the Angelic Doctor.

The man who could dispute with Farges the first place among French neo-Scholastics is Mr. Elie Blane, professor of philosophy in the Catholic University of Lyon.

Elie Blanc is a writer of remarkable fecundity. Having completed a few years ago his Dictionnaire universel de la pensée, a masterly work, which may be deseribed as a natural and philosophical classification of words, ideas and things, he undertook an immense Encyclopedia, which, when completed, will be one of the most imposing monuments of the French language. 'This work, whose title is: Systèmes des connaissances humaines. Encyclopédie chrétienne et française du XX. siècle, will consist of one hundred volumes octavo. The first fifty will treat of the different branches of human knowledge; the next twenty will be devoted to geography; the last thirty to history.

Among Mr. Blanc's numerous productions the following are most especially devoted to philosophy:

Traité de la Philosophie scolastique, published in 1889, and recently translated into Latin with the title, Manuale Philosophia scholastica.

II istoire de la Philosophie et particulierement de la Philosophie contemporaine, very valuable for the indications it contains about contemporary philosophers.

Dictionnaire de Philosophie ancienne, modeme et contemporaine (1906).

Opuscules philosophiques, containing studies about the philosophy of Vacherot, the Ethics of Spencer, the question of free will, ete.

Mélanges philosophiques, essays first published in l'Univers Catholique between the years 1897 and 1900, and in which the author clearly follows the movement of modern thought.

Mr. Blane also wrote, with the collaboration of Mr. Vaganay, a Bibliography of the works recently published in French and 
Iattin. Finally, he fombled in 1903 an important review, la l'mese contemplereine, which has already given many interesting articles in defolnce of the principles of scholasticism.

Bhane. Farges and Hemet de Vorges, with the Jesuits Delmas and lo. Rermon, of whom more in the sequel, are the most dis-

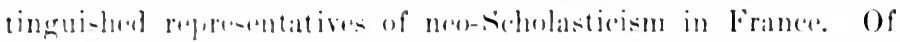
entual or sarong inferior merit aro Gardair, the Marist Peillaube, and the Lominicans ('ocomnier. Sertillangres, Mammus and Mandonmet.

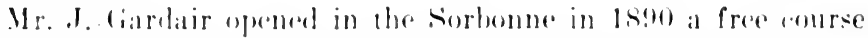
on the philosophy of st. Thomas. Mis lectures have ben sub-repuently published with the following titles: t'orps el the

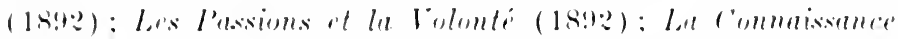
(1S!9) : La Seture humaine (1s!ti) ; and form a compledo

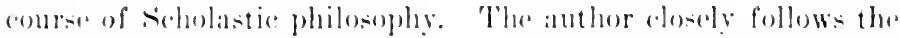
teatehing of st. Thomals Aguinats, and allheres to the doctrine of the Angelic loxtor ren in some points in which this doctrine

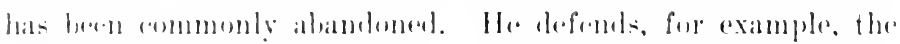

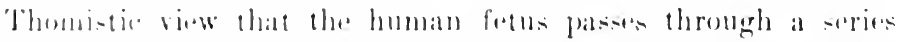
of stages in whinh it is sucessively informmel by the regetative.

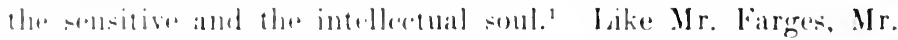
fiarlatir has purposely neplectod many unimportant points, and develual his attention to the most andential sicholastic doctrines.

'The Mariat P'oillanblu is a Thumint of the new sehool, and, like larges and the profenors of louvain, does not hesitate to -tuly the Thomistic primeiples sile hy side with the most recent philonphlieal theories. This position was alroaly taken in his Theorie des comerpts, a thesis he defended before the tatholic

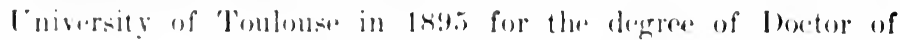
Philusephy. It has berell adhered to in the lierue de l'hileso-

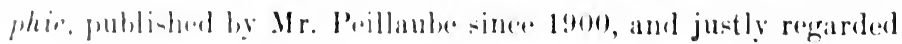
an ond of the best philosephical reviews we posiess to-day.

l'we other Mariets of great morit are Bulliot, of whom Peil-

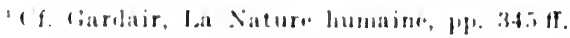


laube has been the disciple, and Ragey, the author of remarkable works on St. Anselm.

The Dominican order has furnished to the cause of neoScholasticism some of its most valiant defenders. St. Thomas Aquinas was a Dominican and has always been a favorite author in Dominican studies. The Dominicans are proud of their great saint, and regard themselves-probably with justice-as his most faithful interpreters. We have already studied the works of Zigliara in Italy and of Gonzalez in Spain.

In France the Dominicans have done immense scrvice to the cause of neo-Scholasticism by the publication of the Revue thomiste, founded in Paris in 1893. 'The Revue thomiste studies theology side by side with philosophy, and contains interesting dissertations about the true meaning of the Angelic Doctor. It is regarded by Mr. Picavet as the most important periodical publication of neo-Scholastic literature.

The Dominican Coconnier is chiefly known for his work l'Hypnotisme franc (1897), in which he attacks the ideas expressed by the Italian Jesuit Franco in another work written on the same subject some years before (l'Ipnotismo tornato di modo, 1886). Fr. Coconnier excludes from "frank hypnotism" all facts of immediate transmission of idcas, telepathy, intuition of the thoughts of other people, vision of the future, etc. He then teaches that hypnotism thus understood is not necessarily supernatural.

Besides this work, with which Scholastic philosophy is not directly concerned, Coconnier has published a treatise on the human soul (1890), in which he studies modern psychological theories.

A. D. Sertillanges has chiefly discussed the problem of God. For many years he has been as assiduous collaborator of several philosophical reviews, such as the Revue thomiste and the Revue des sciences philosophiques et théologiques, and has proved himself to be one of the most profound interpreters of the Angelic Doctor. 
V. Manmus, in sinint Thomas d'Aquin et la Philosophie cartésienne, has mathe a comparative study of the Cartesian and Thomistic philosphy, in which he naturally prefers st. Thomas. One year later, in lees Philosophes contemporains, he has judged very strerely Vacherot, Taine, Janet, Caro ant Sichopenhauer. He is epectally antipathetic to sehopenhamer, whom he charges with having dishonored the history of philosophy.

Pierre Mandonnet owes a well-desterved reputation to the work. Siger de Brabant et l'A lerroisme latin au .1\%lII. siecle, which contains very important data about the great currents of thometh of the thirteenth century, and has been greatly praised by Delateroix, in the Retue de synthese historique (August, $190 \%$ ), and by (iomez Izquierdo, in his II istory of Philosophy in the HIX. century. Mandonnet has made on Mediaval topies other imprertant stulies. Which have appeared in the Recue them iate. Lat us mention the essay antitled, Jean ciont Erigine et forn le sourt. published in $189 \%$.

Gether lominicans worthy of notice are: Jugon, who has: renently (1906i-i) publishel the first two volumes of a course

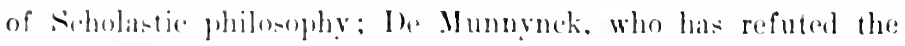
oljections ratied against moral liberty from the theory of the conservation of conergy: (iardeil, who has written interesting articles on neosfontiom: Berthier. Montalgme. Folghera, ete.

The two greatest works with which the French desults have enriched neo-sedholastic literature are: the betaphysique des ('auses of Fr. de Regnom and the ()ntologin of Fr. Delmats.

larn in Saint-Herblain (Iaire Inferieure) on ()etober 11.

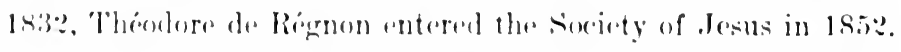
II. taupht mathematies and physical serener in the collene of

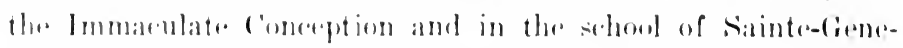

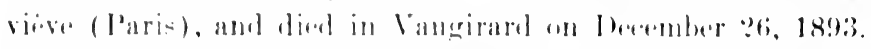

lhering the time he was engagend in teaching, he carefully Fturlied the ereat secholantie doctors, wo that, when the laws of 1880 eparated him from his chair, he was in posesesion of 
important materials which allowed him to complete in a short time considerable philosophical and theological works.

The most important of De Régnon's philosophical productions is his Métaphysique des Causes.

The aim of the author is very modest. He simply wishes to lay before the students of St. Thomas the philosophical notions without which a thorough understanding of the Angelic Doctor cannot be attained: "To make clear the nation of cause by separating it from adjacent notions, to show how the influence of the cause expands into distinct causalities, to explain the nature of these different causalities and their correlation; finally, to show unity and harmony in the action of these different causes: such is my aim. It is a rational plan to contain the great maxims concerning causes, which constantly recur in the treatises of our doctors. It is a preparatory study which may be useful to those who wish to understand St. Thomas in St. Thomas himself.",

With what perfection Fr. de Régnon has carried out the plan thus sketched in his Introduction may be gathered from the eulogistic testimonials of several eminent philosophers. OlléLaprune, while teaching at the Ecole Normale Supérieure, would often direct his students to the Métaphysique des Causes as to a masterpiece. Georges Fonsegrive, in his Cours de Philosophie, pronounces De Régnon's work learned and profound. ${ }^{3}$ Bishop Maurice d'Ifulst calls the distinguished Jesuit "un métaphysicien de prenier ordre."

Charles Delmas published in 1896 an extensive treatise on Scholastic metaphysics, entitled Ontologia Metaphysica generalis. All questions concerning ontology are treated with the greatest minuteness. The author follows St. Thomas, Suarez and modern Scholastics, especially those belonging to the Society

2.étaphysique des Causes, Introduction, pp. 14-15.

${ }^{3}$ Cf. Fonsegrive, Elements de Philosophie, vol. 2, p. 247, note 1.

- Cf. Mgr. d'llulst, Conferences de Notre-Dame, p. 370; Paris, Poussielgue, 1891, 
of Jusus. Fr. Mumas sides with Suarez rather than with St. Thomas whemever a diverenen exists between the two great doetors. Ile thus maintains with suare\% that the distinction hetween the enenere and the existence of croated beings is not real, but virtual." It is gerhaps on aceome of this preforenes that the Ontologria hat been deseribed as a silmmula. Suarezii. Fr. Holmas work is not. lowerer, a mere compendium of suares

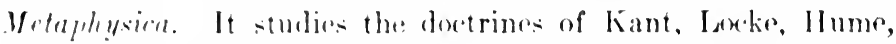
and other modern philosophers. These eonsiderations ahout molern - yetrms are probably the wrakest part of Dolmas's work. I doube whether any student of Kant would recognize the philoseghy of the ('ritique as portrayed in the pages 19-2: of the ()ntologian.

Amomer other writers who have served with distinction the (alus of neo-sidulastirism in Prance let us mention:

Jules Didion (1sto-1903), who has taught for twenty-five vears in the catholir lniversity of lille. His most important contribution to philesophy is: contribution philosophique it

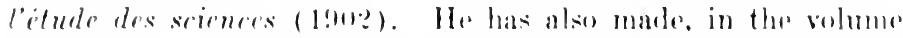
entitled l' sivele, a rapiel survey of the philosophical movement of the world during the nineteenth erentury.

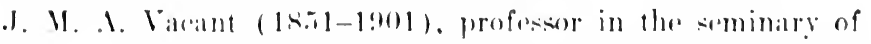
Sancy. Lanant, although primarily a theologian, has written

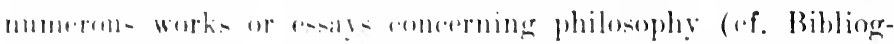
raphy). Mo-t importame amoner them are his comparative

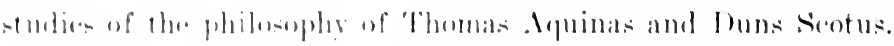

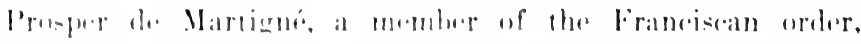

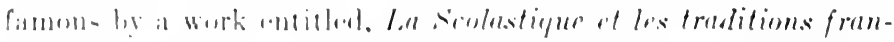

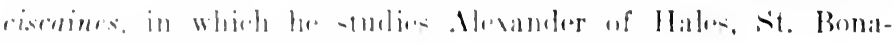

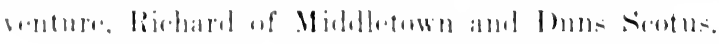

1. Clerval, of the dione-is of ('hartres. anthor of remarkahle

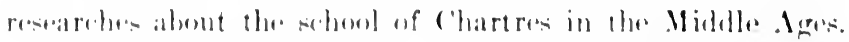

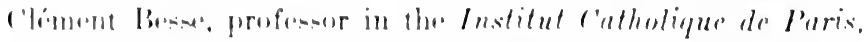

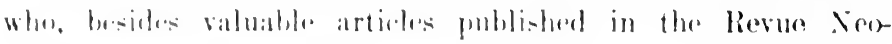

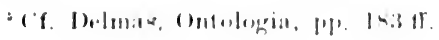


Scolastique and dealing with morality in France, and the volume, Philosophie et Philosophes, has recently written a historical study entitled: Deux centres du mouvement thomiste, Rome et Louvain (1902). Mr. Besse has been reproached with having been unduly severe for Roman neo-Thomism. The characteristic traits of the two great neo-Scholastic schools are, however, faithfully delineated in his work. The chief merit of Deux centres du mouvement thomiste is the historical data it contains about early Roman Thomism, which have been of great service to all subsequent historians of the neo-Scholastic movement.

Carra de Vaux, professor at the Institut Catholique de Paris. who has published interesting studies about Arabian philosophers.

Vietor Bernies, author of the work, Spiritualite et Immortalité (1901), which has met with great success, and of a series of articles on the "active intellect," whose existence he has denied.

P. Mielle, professor of philosophy in the seminary of Langres, who published in 1894 a dissertation entitled, De substantia corporalis $v i$ et ratione, greatly praised by Picavet; ${ }^{6}$ and, more recently (1898), the treatise, La Matière première et l'étendue, in which he expounds and discusses the opinions of the great Scholastic philosophers about primordial matter, and agrees with Thomas Aquinas in regarding it as the principle of individuation of the bodily substance.

Some French writers of great merit, although less strictly Scholastic than those we have studied, have defenderl the essential principles of Thomistic philosophy. Most distinguished among them are Mgr. d'Hulst, Clodius Piat and Georges Fonsegrive.

Maurice d'Hulst (1841-1896), successor of Monsabré in Notre-Dame and first rector of the Catholic University of Paris, is primarily an orator. He has served the cause of neo-Scholasticism by a series of articles which he has later collected and

${ }^{\circ}$ Cf. Rev. Philos., Jan., 1896, p. 61. 
puhlishen in the solume Velanges philosophiques. The volume contains: three opuning lesenne of a free coure of philosophy given from land to lasis, three series of lectures given to the publice and articles published in the correspomdant and the

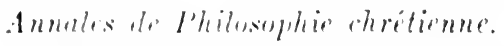

c'lodiu- Piat, professor at the Institut c'atheolique of P'aris, was first knuwn for a memoir on the artive intelledt, written in 18!1, which he puhlished, with greater development, in 1 seth, and entitled l'lle'. In this work Mr. Piat examines and ariti-

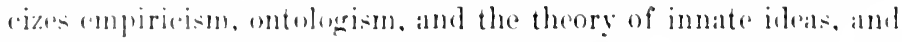
ins-a- upun the esential distinction between the idea and the fhantasm. In lal liberte (1894-95) he discuseses all modern theorits about freedom, and defends the freedom of the will on the grounds of the direct testimony of conscionsnest and of the moral law. Besdes these two grealt works and two others of no les: interest: la Personne humaine (1893) and Destinée de thomme (1sas), Mr. l'iat hats contributed numerous articles to several philosephical reviews and the volume socrete (19000) to

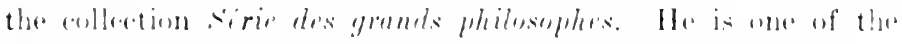
most dietinguished (athelie philosophers of the present day.

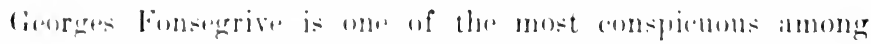

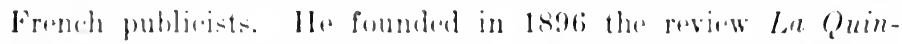
zaine, which hat aletively served for mesen gears (till March.

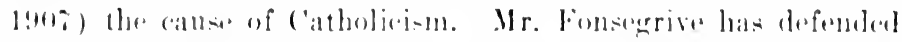
the fundamental sidulatio principles in his Eswai sur le libe

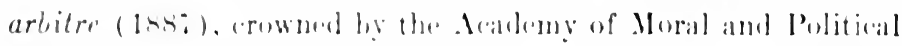

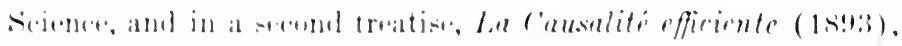

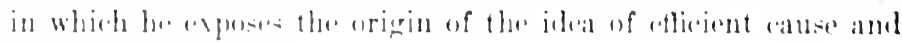
deffrme it: salidity.

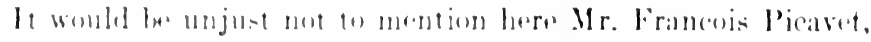
born in Petit-Fayt (Xord) in 1s.il, and actually professor in the department of llautes-letules at the Sorbonm. A primary

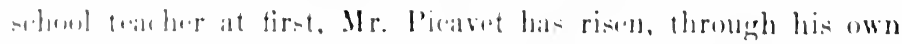
merit, whe high plate he now exenpies in the educational fiedel.

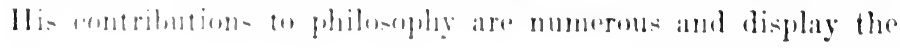


greatest erudition. Of special interest are his studies on Scholasticism. They consist of articles published in the Revue Philosophique, of learned monographs on Gerbert, Abelard, and other Medixval writers, and of a more extensive work, the Esquisse d'une histoire générale et comparée des philosophies médiévales, which has met with a great suceess, and of which we have already spoken. Mr. Picavet does not study Scholastic philosophy with the spirit which has inspired the neo-Thomistic revival. He is not, and does not pretend to be a Scholastic. He has nevertheless contributed more than any other writer to impose the neo-Scholastic revival upon the attention of French philosopher's.

We have mentioned the reviews Revue thomiste, Revue de Philosophie and La Pensée contemporaine. Neo-Scholasticism owes also some gratitude to the Annales de Philosophie chrétienne, which was the first organ of the Thomistic revival. The Annales has recently modified its direction and manifested a marked sympathy for the Kantian philosophy. 


\section{(IIAPTER XIII}

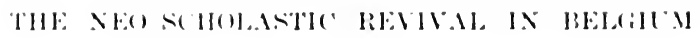

Contelention, or the dectrine of the direct intultion of the 1).ity. Wats the -ystem in vogure in Belgrian philosophic circtes by the midhle of the ninetenth eentury. Chaghs philosophy, as is well known, is directly inspered hy Malebandhe. whose prinriphe it faithfully reproduces. Similar beliefs were professed hy Ihaghes en-workers at the University of lomvain: laforet. ('latesems and Moeller.

This temlency of Belgian thought did not. howeser. preserve for a long time its origrinal foree. After ontologiom had been condemnerl by the chureh in lefil. Thaghs's philosophy was gradually ahamdoned, and a return to st. Thomals began to take place. Amene the profesors of the Iniversity of Louvain whe contributed to bring about this return let us mention Dupont. Bristu, and Isfefire.

So man, however, worked more bravely for the final vietory

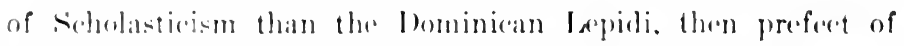
studies in the college of the Immareulate conception of Louvain. later profereser at the Minerva in liome.

In Italian by hirth. Ispidi helongs to Belgrum he his philosephys not only healuse he wrote there his most important works, hut chiefly for the immernse influenere he crercised upon Bengian thenght hy hringing aluent the downfall of Ontologism.

1 onlid refutation of ontenteriom is indered the work entitleat

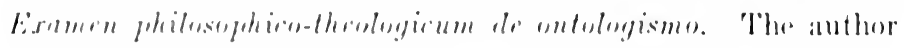

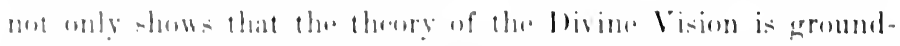

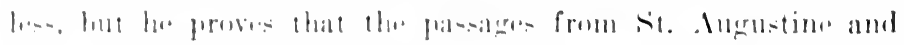

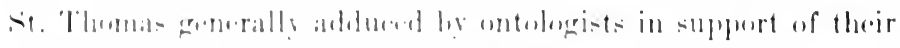

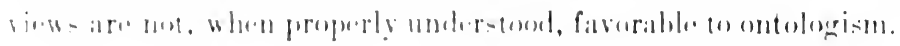


No less recommendable is Lepidi's Elementa Philosophice christiance (1875-\%9). It contains a clear and methodic exposition of Scholastic logic and metaphysics, and may be regarded as one of the best contributions to neo-Scholastic literature written previous to the encyclical Eterni Patris.

A distinguished worker of the first hour was also Van Weddingen, chaplain of the court. His first work, Essai critique sur la philosophie de saint Anselme (18\%5), was crowned by the Royal Academy of Brussels. Proposed by Leo XIII to teach philosophy in the University of Louvain, he declined the offer, preferring to keep his functions at the court, but he powerfully contributed by his writings to give to the Thomistic revival a sure footing in Belgium. Besides a commentary on the encyclical Aterni I'atris, in which he splendidly sets down the program of neo-Thomism, and important treatises on St. Anselm, Albert the Great and St. Thomas (cf. Bibliography), Van Weddingen has given to neo-Scholastic literature an extensive work, his Essai d’introduction à l'étude de la philosophie, which consists of no less than 900 pages quarto, and studies the question of the objectivity of knowledge, a question to which the Critique of Pure Reason has given a capital importance.

The neo-Scholastic revival in Belgium has been chiefly fostered by two great centers of learning: the College of the Jesuits of Louvain and the Institut Supérieur de Philosophie.

The most celebrated among Belgian Jesuits are De San, Iahousse, Castelein, Van der Aa, and Carbonelle.

Louis de San (1832-1904) is reputed as one of the most profound thinkers the Society of Jesus has produced. For more than thirty years he taught philosophy and theology at Louvain. His theological productions are numerous. Inhappily, he has contributed to philosophy a single volume on cosmology, one of the four volumes of a work entitled: Institutiones metaphysica specialis, which the learned Jesuit had in view, but never completed.

De San is thoroughly acquainted with modern philosophy. 


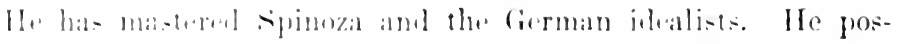

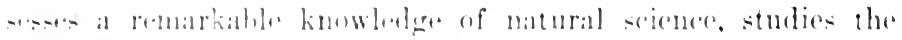

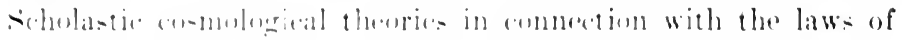
whenistry, and find in ehemistry itat if the proof of the Thomintire primeiple.

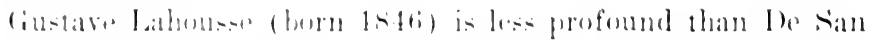

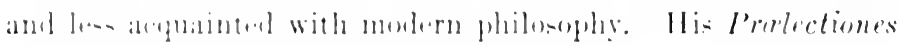

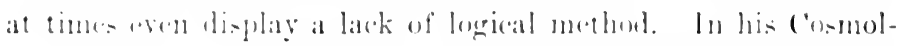

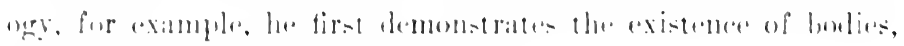
and nest the objectivity of semsation.

John Vian der Aa (born 18t3) is strictly sidholistie and igneres many modern problems. In his lagic he renluees induetion to : sllogiom.

Much mene metern in his methet, much mere familiar with

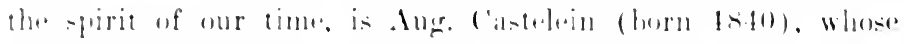

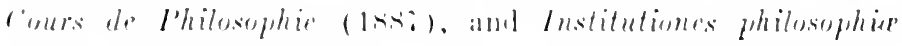

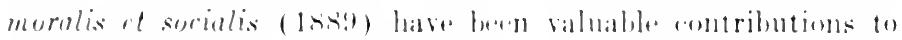

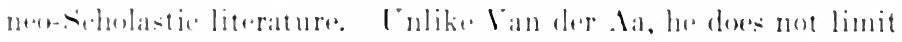

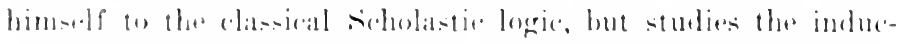
tive precesen and diecusese the vilue of hypethesis and of experi-

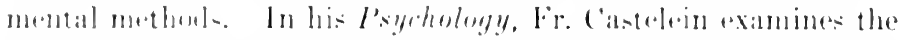
scholistice teaching abuut the soul in connection with motern physiological datit.

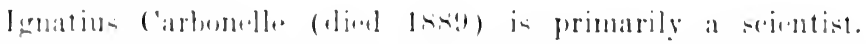

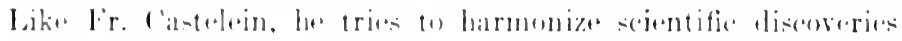

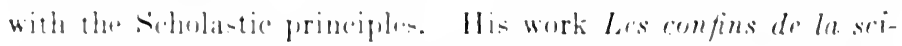

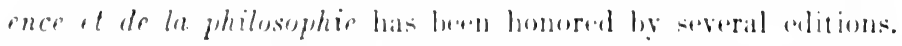

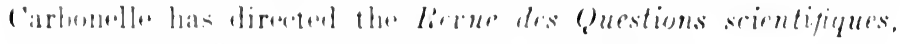
che of the mot important betgian publications.

Alhough the dentit college in then an importint center of

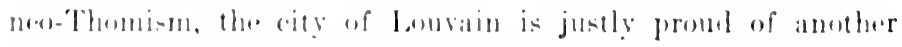
conter incomparably more impertant, of a conter which hats

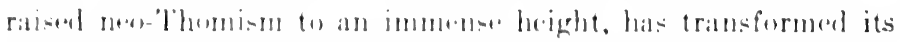
charater and methent, giving it a new life, hringing it inte con- 
tact with modern progress and modern ideals. It is the Institut Supérieur de Philosophie of the University.

The peeuliar character which distinguishes the Institute of Louvain from earlier centers of Thomism is chiefly due to the initiative of its first president, Desiré Mercier.

Born in Braine l'Alleud (Belgium) in 1851, Desiré Mercier began his studies in the seminary of Malines, and completed them in the University of Louvain. He was subsequently given the chair of philosophy in the seminary of Malines. This was precisely the time in which Leo XIII, having been elected pope, was promoting in Italy the revival of Scholasticism. Cornoldi was then giving his famous course, silencing all opponents with the authority of St. Thomas, resolving all scientific doubts by the Summa Theologica.

Leo XIII who, when a young man, had inhabited Belgium as a papal nuncio, and had kept of that country the most delightful remembrance, was trying to make the neo-Thomistic revival step beyond the limits of Italy, to create in some other country an institution similar to the Roman College, to the Cornoldi school. Nowhere could he find a more favorable ground than in Belgium. By the brief of the twenty-fifth of December, 1880 . addressed to Cardinal Deschamps, archbishop of Malines, the pope urgently recommended the foundation of a chair of Thomistic philosophy in the University of Iouvain. So great was then the renown of the young professor Mercier, so successfully had he fulfilled in Malines his professorial duties, that he was chosen to earry the papal designs into effeet.

The suecess was great. It did not, however, satisfy the pope. who understood that something still greater could be done. $A$ few years later-the eleventh of July, 1888-Leo XIII sent a second brief to the archbishop of Malines, Cardinal Goossens, recommending the foundation of an institute of Thomistic philosophy, endowed with its own independent life. Iraving learned that the greatest difliculty was the lack of funds, he sent to Cardinal Gonssens the sum of 150,000 francs. Great was the 
energy displayed be the belerian catholies to realize the papal irleals. Their effort- were finally rowned with sucess. and in ls!l the lnstitute of lhilosophy of lowrain, the glory of neoThomi-m, wats othicially croalted.

In a memoir read before the congress of catholices hald in Malines in siptember. 1s!t, Mercier traded the program he hand in view to insure the success of the new foundation. After represcuting and deploring the isolation from the rest of the scientifie world to which catholies had andemned themselves, he outlined the reforms he contemplated, the new road he intended to opern to men-sicholanticism.

'lhe reforms which eharacterized the school of louvain maty be elassified under two heads:

1. Philosophy was mot to be regarded as a mero ancilla theologur, but to be studied for philosophy's sater. Catholic philosophers would thus frankly enter into the spirit of our time, and cease to be looked upon as mere apologists of their c'reedl.

2 Just as philosephy was to be studied for its own sates so also was science. Porthomists had to hecome true sojentists, to construet laboratories, to make experiments, and-this was the point which at first savored of paradox-to find in st. 'Jhomas himelf the reconciliation of science and philosophy.

'This last ambition was not nowel. It was the very aim ('ornoldi had eherished many yoars hefore, the very spirit which had inpired the encyliand . Eterni Patris, hu thus far nothing strions had been done.

Meroiner proposerl: fir-t of all, to stuly st. 'Thomas in his original works, to open the summa Theologica, the summa con-

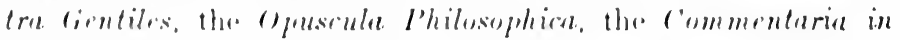
Aristoteles. It was the fommd that a great many opinions which, for centuries, had leen ridienled under the name of 'Thomi-m, were not from st. 'Thomas, but from writers of the

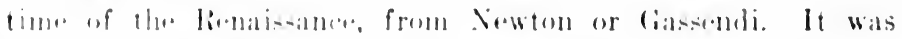

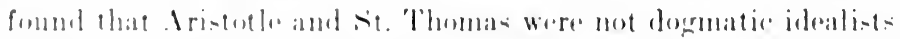

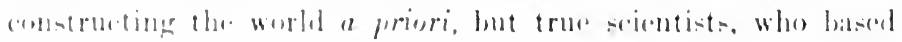


their philosophy upon the facts of experience; that their doctrines were not antiquated and useless theories, but possessed a character of modernness which many recent systems might envy.

Modern philosophers were likewise to be studied in their original works. Descartes and Kant were not to be reached any longer via Sanseverino. The Discourse on Method and the Critique of Pure Reason were to be read and understood. Thus and thus only could the spirit of modern philosophy be grasped; thus only could neo-Thomism keep abreast with the rest of the learned world.

The success of the Institute of Louvain has been prodigious. Mgr. Mercier has found at first many opponents among Catholics, ${ }^{1}$ but he has always answered victorionsly. The numerous articles on neo-Thomism which, since the foundation of the Institute, have appeared in the Kantstudien, the Zeitschrift für Psychologie und Physiologie, the Revue Philosophique, the Rivista Filosofica, and many other publications, show how well he has succeeded in breaking the studied silence with which the Thomistic revival had been previously received.

The Institute of Louvain, so successful in point of philosophy, has also obtained significant results in the field of science. It the head of the department of science is Mr. Thiéry, a former pupil of the famous Wundt, of Leipzig. About the laboratory he has founded in Louvain, Mr. Binet could write in the Année Psychologique of 1896: "For the course of Mr. Thiéry there is a laboratory and complete equipment for physiological psychology such as does not exist at present in all France." A similar laboratory has been subsequently founded at the Sorbonne (Hautes-Etudes).

Under the direction of Mgr. Mercier, a Course of Philosophy has been published to which Mercier himself has contributed the volumes on Logic, Criteriology, General Metaphysics, and Psychology. Less extensive than the Institutiones of Urraburn, Mercier's Course is much more modern. It discards questions

' ('f. Billia, L'esiglio di San Agostino, Torino, 1899. 
which in our day may be dismissed at usoless, and studies scientific results in themselves, without giving, at the head of each chapter. a decision of the ('ouneils or a passige from the saced seriptures. with which the data of seience must be foreed into harmony.

The sueess of the "lours de Philosophie" of the Institute is aloguently tertified by the numerous editions which have bern mate in a few years, and the translations into Cerman, Italian, Spanish. Portuguese and Polish by which it has heen honored.

The catholic ('hurch has not heen indifferent to the great service done by Mercier to the cause of neo-Thomism. The illustrious founder of the Institute of Louvain has been offered

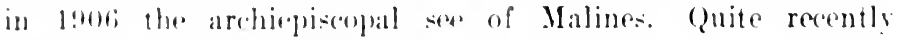
(. Ipril 18, 1908) he has been made a cardinal.

The arduous task that bay before Mercier in 1 s!l has been greatly facilitated by the action of distinguished collaberatorwhe at ence grateped the program of their master and imbibed

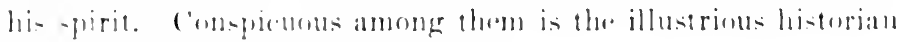
of Mediatral philuenhy, Mr. Me Mulf.

Maurien de Wulf (born latia) wats alrealy known before his

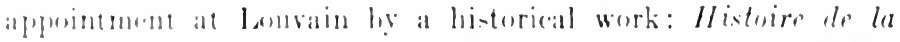
philonopher scolestiquer dans les P'ays-Bas et la Principaute de

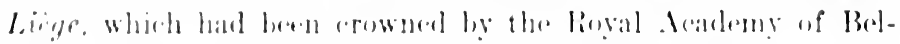
grium. Sine then he has written numerous works or exilys of

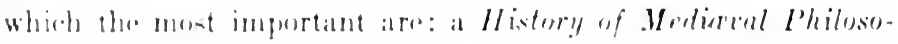

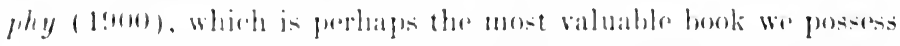

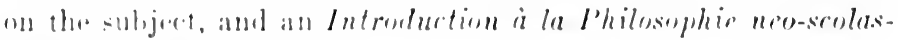
tipue. publinled in 1901.

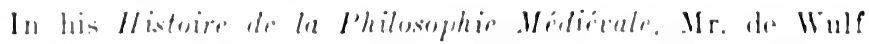
depart: from the common view which identifies sibolaticism

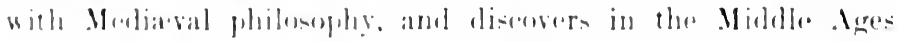

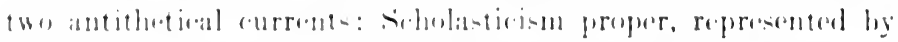

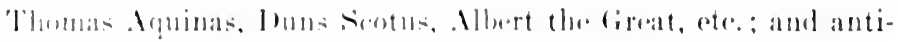

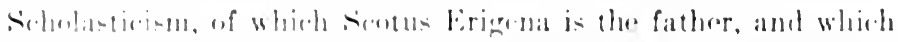

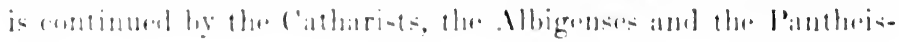


tic schools. Mr. de Wulf's view on this point has not met with a ready acceptance. It has been rejected, among others, by Elie Blane and Picavet. Mr. de W'ulf, however, still holds the same opinion, and has defended it again in his Introduction à la Philosophie Néo-scolastique.

The aim of this last work is to remove current misconceptions about the nature of Scholastic philosophy; to give, as in a nutshell, the essential traits of Thomism, and to show to what extent neo-Scholasticism agrees with the Scholasticism of the Middle Ages, and to what extent the old philosophy has been modified. In no other work is the program of neo-Scholasticism so definitely outlined. The study of Mr. de Wulf's Introduction is indispensable to those who want to enter the field of neo-Scholastic literature.

With the collaboration of Mr. A. Pelzer, Mr. de Wulf las lately undertaken the publication of unedited works of Mediaval Belgian philosophers. Among the volumes already published let us mention: Le Traité De Unitate Forma de Gilles de Lessines (1901), Les Quatres Premiers Quolibets de Godefroid de Fontaines (1904).

Mr. D. Nys is the cosmologist of the Institute. Besides two volumes dealing with St. 'Thomas's conception of time and space, and many articles published in the Revue Néo-Scolastique, he has contributed to the Cours de Philosophie of the Institute the volume on Cosmology.

In no other work-safe perhaps in Farges's essays-are the Scholastic theories about the world so satisfactorily expounded. Nys's Cosmology is even more scientific than Farges's works on the subject. All modern discoveries, all recent scientific results are discussed in connection with the Scholastic system. We may fail to agree with Mr. Nys's conclusions-and I confess that this is my case-but we cannot entertain for a single instant the idea that his conclusions are not the result of a serious study of the matter. 


\section{3}

Among the men who have homored the Institute of Lowvain by their phiberphical proluctions we must al-o mention:

l. Doel. who has writum valuable worts on the question of determinism and frew will.

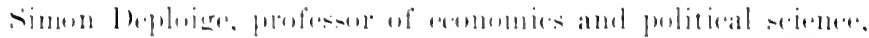
who hat puldished a treatian on the 'Thomistic theory of property and a mone interestimgr asty antitled, st. Thomas et la question juite: and E. C'rahay, amthor of a work doaling with sit. Thomas: political doetrines.

Finally, the Institute of Isturain desorves the grattitude of all lovers of philesophy hy the publieation of one of the most

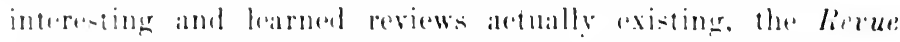

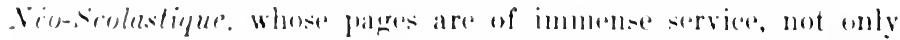
in thow interestad in neos-s(holasticism, but to all students of philonoply. 


\section{CHAPTER XIV}

\section{THE NEO-SCHOLASTIC REVIVAL IN OTHER EUROPEAN COUNTRIES}

\section{Section 1.-Thie Neo-Scholastic Revival is Huxgiry, Bollemia AND the Netherlands}

The countries we have studied thus far are those in which neo-Scholastic philosophy has especially flourished. The Catholies of the rest of Europe have not failed, however, to espouse the views of Leo XIII, so that the Thomistic literature of the present century is proud of many productions with which the foregoing chapters have not dealt.

Among the countries in which Thomism has found able representatives, Hungary holds a prominent place. As early as the sixteenth century, Scholastic philosophy flourished in the seminaries erected, according to the spirit of the Council of 'Trent, by Nicholas Oláh and Cardinal Peter Pazmány, S.T., archbishop of Esztergom. The control thus exercised by Scholastic prineiples upon Hungarian thought became stronger still through the liberation of Hungary from the Turkish rule. And it thus happened that, in the eighteenth century, while Scholastic philosophy was rapidly losing ground in the rest of Europe, it was regarded in Hungary as a necessary complement of a liberal edueation.

In the nineteenth century, howerer, the influence of the French revolution and of German rationalism produced a notable change in the attitude of Hungarian thinkers. As was to be expected, this change was unfavorable to the traditional Christian philosophy. Scholasticism soon lost its former prestige and was finally rejected from the gymnasia, even from the seminaries.

Such was the state of things when the encyclical Etermi 
I'atris. like an electrice spark, produced a sudden change in the attitule of Ilungarian (atholies. Sicholastic philosophy became an erential element of erelesiastical studies. In this remarkable mowement the (intral Siminary of Budapest and the Seminary of Eatergom towk the lead. They were soon followed hy wher-, an that nowaday- rery fow eceleciastical institutions are still larking a chate of philesophy.

Not long afterwards a siociety of st. Thomas was founded in Bublaper (1593) and an impertant periodical publication, the

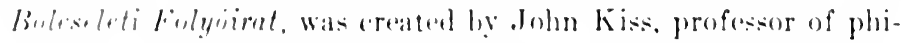
lenphy in the siminary of l'me-var (18sig). Since its fommlation. the Balleseleti Folyoirat has served the (anse of neoThemism with \%al and suecess. Among its most distinguished (ontrihutors, let us mention J. Koziry, st. Szekely. (). Pro-

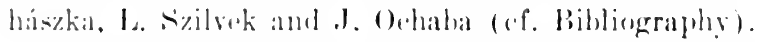

Hungarian ('atholies have not limited themselves to the arti-

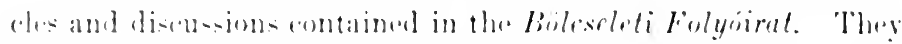
have also enriehed nen-seholastice literature with many separate works which. whiappily-on alecount of the very language in whinh they are written-are not known outsile of Hungary ats well as they deserve. Most impertant among them is the work entitled lnstinct and Intrlled (189s). written by St. Sxékely,

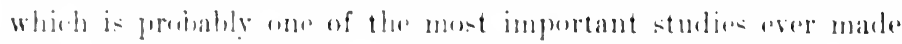
about animal instimet: and the two remarkable volumes of Bishof ottokarus Prohisakis. The first of these, (ionl and the Ileorld (1s:1), deals with the arguments for the exintenere of at Supreme being, whereas the second, Hearen and barth (1901), is a cormogonly.

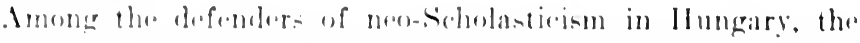

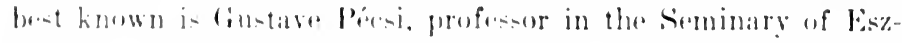
teremen. This is due, in the firet plate, to the originality of some of his themries, and al as to the fact that his mont important works hase hern written in Iatin.

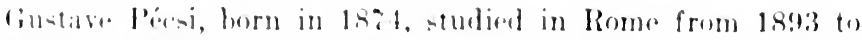
19000, and received the degreen of Dector of Philosophy and 
Theology. Since 1902 he has taught philosophy in the Seminary of Esztergom.

His chief work is entitled Cursus Brevis Philosophice, and consists of three volumes. The first, dealing with logic and metaphysics, appeared in 1906; the second, dealing with cosmology and psychology, appeared in 1907; the third, dealing with natural theology and ethics, has not appeared yet.

The importance of Mr. Pécsi's philosophy is chiefly due to his section on Cosmology, which marks a most significant phase in the evolution of neo-Scholasticism. Two doctrines of his deserve a special mention: his theory of Matter and Form and his ehapter on Energetics.

To many sympathizers of neo-Scholasticism the endeavor to revive the theory of Matter of Form had appeared a fruitless attempt. In view of the actual condition of physical science, the defenders of hylemorphism left the impression of men who would eover a dead body with a new garb. For Aristotle, primordial matter was an indeterminate abstraction, something which was, and yet was not, " materia neque quid, neque quantum, neque quale, neque aliud quidquam est."' This mysterious entity had been accepted by the great doctors of the thirteenth century, and still lingered in all treatises of Scholastic philosophy. Those men themselves who were defending Scholasticism from a scientifie point of view had not dared part with the fetich. Mr. Albert Farges had clung with all his might to the old idol. Mr. Nys had proved himself to be less reluctant to concessions; he had not yet, however, been bold enough. First among neo-Scholastics, Mr. Péesi has formulated the theory of Primordial Matter in a form which men of seience may aecept.

He identifies Primordial Matter with the ultimate ground of all material reality, the ether. ${ }^{2}$ The materia prima thus ceases to be an empty abstraction: it becomes something conerete, a

${ }^{3}$ Metaph., Bk. VI, c. 3.

${ }^{2}$ Cf. Péci, C'ursus Brevis Philosophix, Vol. 2, pp. $34 \mathrm{ff}$. 
reality whowexistenee is testified hy natural secence itself. ${ }^{3}$ As for the -ubstantial form, Mr. P'éci identifies it with the interattmilic anergy:

In the section of his ('osmology entited "linergetice." Mr.

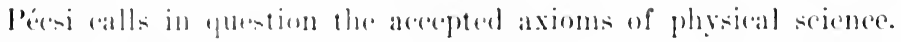
He refutes the prineiple of the conservation of enerege, which he regarta at the foundation of materialism. He also refutes or correcte the law of entrope and the laws of cewton on inertial and atetion and reaction. 'lo the traditional laws of motion he oppore the following laws:

1. Ill physinal bedies prersesere in the state of rest unless immelled by an external foree. But the boly impelled by an external fores mosen only proportionally to the impression rewived from the external fores and al ways in the direction of the imprestion.

$\because$ the intemeity-or selocity-of the motion depends npen

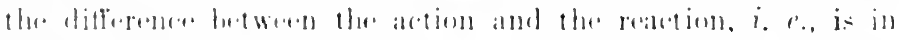
dirent mathenatioal propertion to the aletion, ame in inverse mathematical preportion an the reatetions.

3. If the mutual relation of the antion and the reaction in -uhtsequent mements is constant, nution will be uniforms if the mutual relation of the atetion and the reaction is molified, the metion will atase to be unfurm and anderation or retardation will follow:

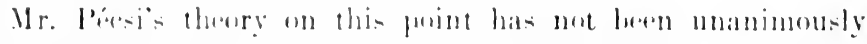

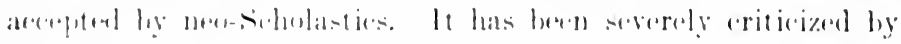

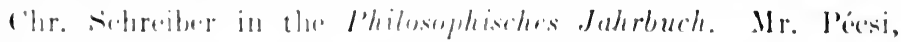

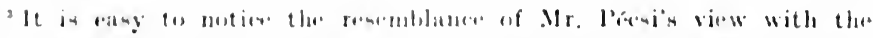

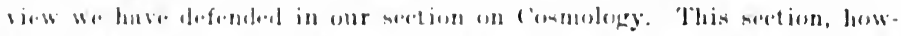

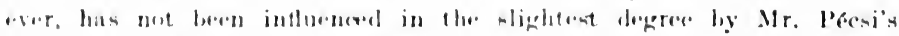

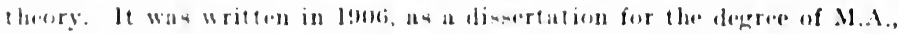

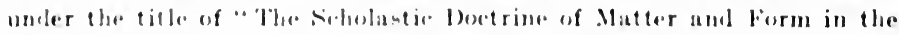

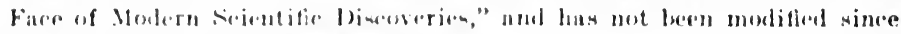
the pullication of Mr. Pereite work.

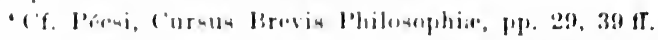

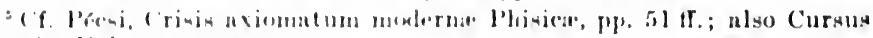

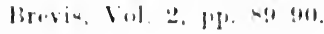


however, has developed it anew in a separate treatise, written at first in Hungarian and translated into Latin by the author himself, under the title of Crisis axiomatum moderna Plisica.

In Bohemia the Thomistic movement is represented by Vychodil, who, in 1889, published a work dealing with the proofs of God's existence; Eugene Kaderavek, the author of several works inspired by the purest Scholastic prineiples and of important articles published in the Philosophisches Jahrbuch and the Jahrbuch für Philosophie und speculative Theologie; Havaty, Pospisil, etc.

In the Netherlands, a chair of Thomistic philosophy was founded in 1894 at the University of Amsterdam and confided to the Dominican Van de Groot. A better choice could hardly have been made. Fr. Van de Groot is one of the most learned and enthusiastic admirers of the philosophy of the Angelic Doctor. In many remarkable works, written in Dutch or in Latin, as well as in artieles published in the Divus Thomas and the Revue Thomiste, he has proved himself to be one of the most worthy champions of the Scholastic eause.

Let us mention also the Jesuit Vogels, who published in Amsterdam, in 1900, a treatise on Free Will, the first contribution to neo-Scholastic literature written in the Flemish language.

\section{Section 2.-The Neo-Scholastic Revival in Exgland}

In the general return of the Catholie philosophical world to the principles of St. Thomas, England has not remained a laggard. A few years after the promulgation of the encyclical Eterni P'atris, Thomas Harper, S.J., published his Metaphysics of the Schools, still considered as one of the most important works inspired by Scholastie principles during the nineteenth century.

Born in London in 1821, Thomas Harper abjured Methodism and entered the Society of Jesus in 1852. For several years he taught philosophy at the famous college of Stonyhurst. He died in 1893 . 
His Methphysics of the schools is an endeavor to present the metaphysical principles of the schoolmen in a form accessible to English readurs. By the thoroughness of the exposition and its depth of thought the Metaphysies of the sichools must be reckented at one of the must valuable neo-scholastic productions. "In Englanl, wrote lemet de Vorges in 18sis. we find only one nen-sidulantie writer worthy of mention. But what an author! What a monument! Like a pyramid bathed in the dew of fifty centuries. it rears its massion form aloft in the midet of a dewert. The Metaphysics of Fr. Harper is certainly the greates work thus far produced by the Thomistic movement. It is also perhaps the most profound, a work that shows the eminent dialectical faculties of its athor in all their brilliancy."

Mere recently, the binglish desuits have acquired a new title to the gratitude of all lovers of sicholastice speculation by the publication of the stonyhurst l'hilosophical siries, which is the most valuable expesition of sicholastic philosophy written in the Englioh language.

The arim, of which sureral editions have been made in a fow gears, comprises the follewing works: logre, by Richard le ('larke. A.l. : First Principles of Knowlenlye, by John Rickaby, S.J. : Moral Philosophy, by Joseph Rickaby, s.J.; Natural The-

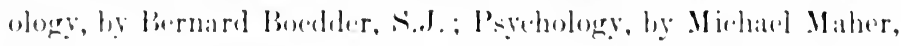

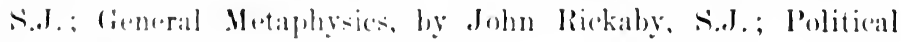
Eomomy, by ('. S. Devas.

Particularly worthy of attention are Maher's P'sycholegy and Pinendler's Satural Thoulegy.

Fr. Maher's l'sychelegy expesese in a clear and attractive

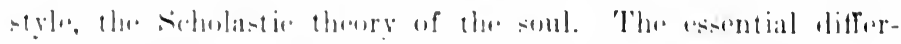

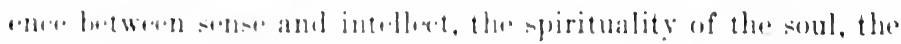
frentem of the will, are demonstrated areording to the best

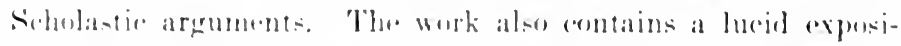
tion and saluable eritiofins of the philosophieal syitems of Kant. Ianhe. Hume. Mill, Bain, spencer and other Pritish aso-

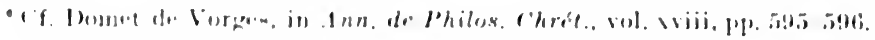


ciationists. It studies the recent hypotheses about the relations of body and soul and pronounces the double-aspect theory contradictory to experience and to reason.

Boedder's Natural Theology, in addition to the chapters dealing with the existence and the attributes of God, in which the Scholastic doctrine of the Divine Being is clearly and faithfully expounded, contains a dissertation about the much-disputed question of physical premotion. After a fair exposition of both views, Fr. Boedder declares himself in favor of Molinism and gives serious reasons to show that the so-called Thomistic theory does not really belong to St. Thomas.

A few years after the publication of his Natural Theology, Fr. Boedder enriched neo-Scholastic literature with two Latin treatises dealing, the one with Natural Theology, the other with Psychology. These treatises form two volumes of a new course of Scholastic philosophy, published in Friburg by the Stonyhurst professors, and known as Cursus Philosophicus (cf. Bibliography).

Joseph Rickaby (born 1845), besides the volume on Moral Philosophy of the Stonyhurst Series, has contributed several important publications to English neo-Scholastic literature. In 1906 he gave an annotated translation of the Summa contra Gentiles. In the same year he published the work, Free Will and Four English Philosophers (Hobbes, Locke, Hume and Mill), in which he defends the freedom of the will against the determinist theories of these philosophers. His method is to quote a passage from the philosopher under examination and then to discuss it.

Richard F. Clarke, the author of the treatise on Logic, has contributed several important articles to the American Catholic Quarterly. He has also published a dialogue on the existence of God, which is one of the most charming philosophical dialogues ever penned.

Among the actual defenders of neo-Scholasticism in Lingland, the most prolific is probably Francis Aveling (born 1875). In 
quite a number of review articles and short treatioes he has proved himself a valiant thampion of the Themistice ealuse. One

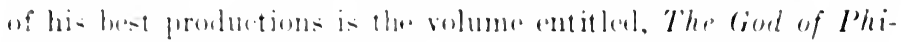

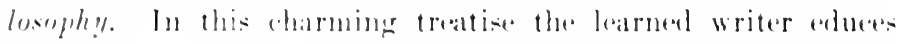
the natural prowefs for the existener of ciont. His style is simflu. elar and concion. The philesophical argument- are shorn of their rigrility and presented in a most fatcinating anperet. 


\section{CHAP'TER XV \\ THE NEO-SCHOLASTIC REVIVAL IN THE UNITED STATES AND CANADA}

Section 1.-The Neo-Schollatic Revival in the Uxited States

Stanley Hall's half-serious, half-jocose words, that "philosophers are as scarce in America as snakes in Norway," could not, without injustice, be repeated to-day. During these last years the European philosophical publications have so frequently studied the works and opinions of our writers that we may, without too much presumption, entertain the belief that philosophy has at last established a permanent settlement among us.

In this phase of our intellectual growth, our Catholic writers have naturally turned their attention to the official philosophy of the Church, so that neo-Thomism, although it has produced in our country no work which may compare with the great European contributions, has nevertheless given rise to excellent treatises which no student of the reent Thomistic movement should neglect.

In the middle of the last eentury the greatest Catholic writer in America was Orestes A. Brownson (1803-1876). His philosophy, which may be deseribed as a form of ontologism, exerrised a great influence upon American Catholics. Gioberti became the man in whose works the only true philosophy was supposed to be found.

Among the writers who were thus controlled by ontologistic principles, one of the best known is Henry $A$. Brann (born in 1839). In his "Curious Questions," published in 1866, he does not hesitate to call (iioberti the greatest philosopher of the nine- 
Eenth antury. Aceording to Mr. Brann, liod is an ohject of

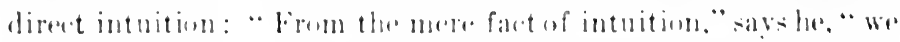

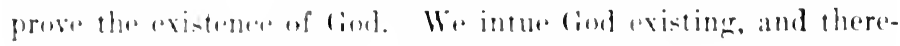
fore we saly He axiste. 'This argument is the strongest an ac-

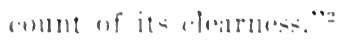

In - wher of his works, howerer. Mr. lirann is in perfect angerement with the prineiples of the seholasties. and eren follows there line of reat-oning. The small work. The sirituality and

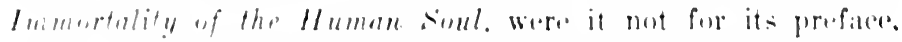

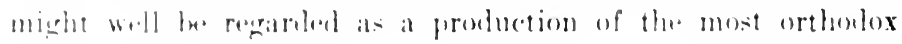
nur)-l'humi-t.

Th the desuits helonges the honor not anly of having heen the fir-t defonders of 'Thomism in the Fnited states. hut of having furni-hed the larerer and more valuable part of our neo-scholastic liturature.

The first works written in dofollso of soholastio prineiples in

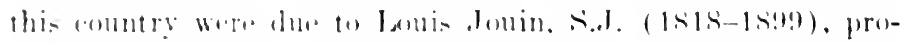

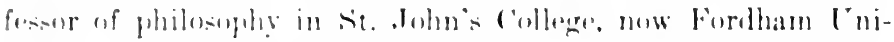
versity. Father Jouin's works emprise two rolumes in latin:

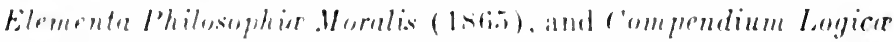
et Metaphysiot (1stig), and a shorter mammal in English: Logic end Metaphysics. 'They have lewen homorenl hy mumerous alitiens and are sill und as fext-herks in soreral institutions.

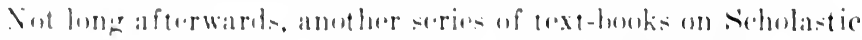

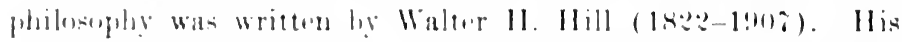
"Eloments of Jhilesephy." of which numerous enditions have leen mate. was puhlisheel in las:3. for the use of the students

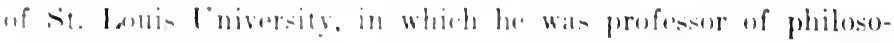

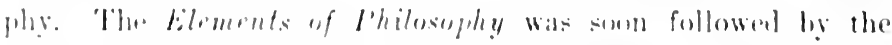

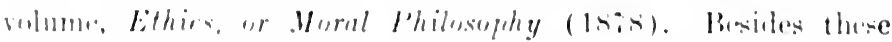
two worke, Father Hill hat writen, in defence of the scholastic

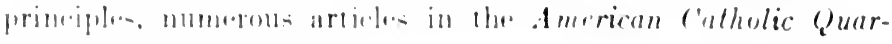
terly (1.f. Bibliography).

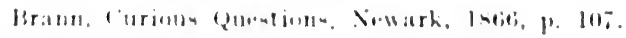

: $11,1,1$. P. 15: 
'The year $18 \approx 3$ was also the date of the publication of Schiffini's Logica generalis Institutiones. An Italian by birth, professor in the house of studies of the Jesuits in Woodstock (Maryland), Biagio A. Schiffini embodied in his work the lessons he had given to the scholastics. He subsequently published some of St. Thomas's treatises: the De Homine, in 1882, and the De Motu IIominis in Deum, in 1883.

Among the courses of Scholastic philosophy written by the Jesuits in the United States, the most valuable are probably the two volumes of Nicholas Russo (born April 24, 1845; died April 1, 1902). His Summa Philosophica (Boston, 1885), in which he generally follows Liberatore, more complete than Jouin's works, is generally regarded as the most satisfactory exposition of Scholastic philosophy published in this country. In his De Philosophia Morali (1890), Fr. Russo published the lectures he had delivered to the students, when professor of moral philosophy in Georgetown University.

Among the courses of Scholastic philosophy thus written with special regard to the needs of the students, we must also mention the works of Charles Coppens and William Poland.

William Poland, born in Cincinnati in 1848, and professor of philosophy in St. Louis University, is the author of several treatises in which the fundamental principles of Scholasticism are expounded and defended in the clearest and most attractive style. His "Truth of Thought" (1896) is an excellent textbook on criteriology. Like all Scholastics, Father Poland holds a middle position between the idealist and the materialist. He skilfully points out the inconsistency of subjectivism, ${ }^{3}$ and proves the objective character of reality by means of the evidence whereby it is presented to us as objective:

"Just as in the perception or knowing of self, I affirm self. so also, for the same reason, evidence, I atfirm, with inevitable conviction, the objective value of non-self. I have a thought or a headache. The thought or the headache presents itself to me

${ }^{3}$ Cf. Truth of Thought, pp. 197, 61. 
as mine. I therempon have a comviotion that it is mine. of this convietion. artitied in the pereeption of what is evident, I camot rid mbelf, and l hold to it. The midnight glory of the star- fre-ents itself to me as a something which excludes the element of mbelf. I have, therempen, a comvition of that something. al - tromg as the comvietion of my own thenght : and simultantemaly I have a comsiction that that something is dis-tinet from me. Of this ansiction, antified in the pereeption of wlat is eviblent, I anmot rid merelf: and I hold wo it."

The ductrine contabed in this quotation is not, howerer, perferetly elear. We believe a thement to be subjective and the starral sky abjertive. heratese the former depends upen our will. while the batter does not : beranse we an have or reject a thought

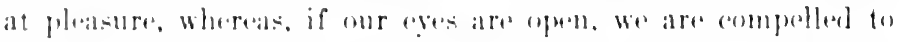
se the sky. But, why should a hadache he any less ohjeetire than the -tarreel -ky? Does it depend upon a fiat of our will? fan it lo rejected ats readily as we please? It is an affection

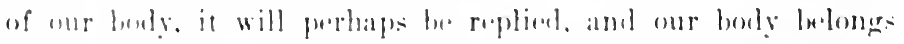

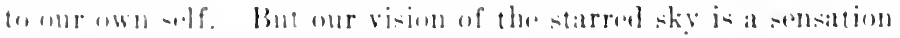
of andor which belonges to our holy ju-t as well. Why, then, -lombl the sky le abjeretive and the headache subjection? This is a geretion which Fr. Poland dores not fater.

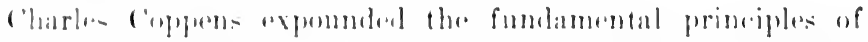

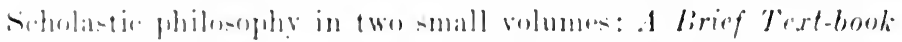

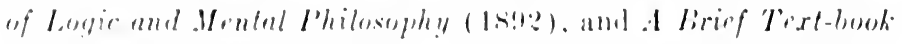

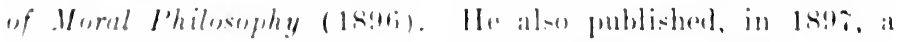
remarkable work upun which his fame ehiefly rests: Moral l'rinciples and Wedial I'ration. In the light of the l'hrietian prin.

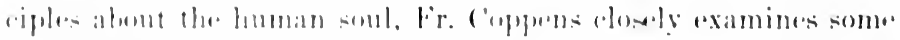
unbjerts, -meh at araniotomy and alortion, which are of burning

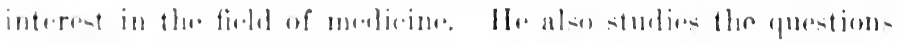
of insanity and hypmotiom, and lays down, in the most ablete manner. the profeceional rights and dutien of the physician.

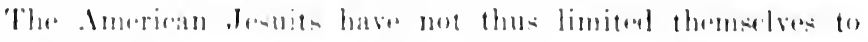

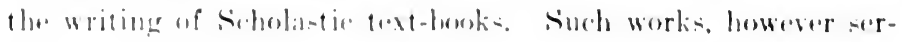

- Polame. Truth of Thenght, P. Sis. 
viceable they may be, exist now in so great a number that new ones cannot but repeat what others have already said. Fr. Coppens's work is one of those studies on particular questions to which neo-Scholastics should now direct their attention. Another study in the same direction has been made by Rene I. Holaind in his Natural Law and Legal I'ractice (1899), which contains the lectures he delivered at the Law School of Georgetown University. Fr. Holaind carefully studies the capital questions of taxation, capital and labor organizations, strikes and boycotts, etc. The solutions he gives are inspired by the principles of Christian philosophy, and perfectly adapted to the actual conditions of society. Not only all students of law, but all American citizens should read and meditate this work.

John J. Ming, professor of Moral Philosophy in Canisius College (Buffalo), besides numerous articles in the American Catholic Quarterly, has contributed to American neo-Scholastic ethics a precious work, entitled The Data of Modern Ethics Examined.

The aim of the author, as set forth in his preface, is to defend ('hristian ethics against the recent moral systems advanced by the modern schools of Positivists and Agnosties.

The several forms assumed by hedonism are faithfully exposed and examined at great length. The author is fully conversant with the theories of Spencer, J. S. Mill, and other English empiricists. His criticisms are often excellent, always interesting, and display a remarkable power of analysis.

The hedonistic system of ethies is not, however, as Fr. Ming seems to imply, essentially connected with positivism and agnosticism. The strongest believer in the spirituality of the soul might be as frankly and as consistently a hedonist as Mill or spencer. A refutation of materialism or agnosticism will not therefore be, at the same time, a refutation of hedonism. This is a truth which Fr. Ming seems to have overlooked. As his work is a tratise on ethics, it ought to attack frankly hedonism 


\section{$\because: 3$}

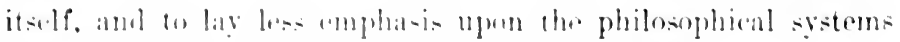
with which hedunism is but alcidentally connectedl.

It is twe that the dharateriste fallaty of hedenism-its confusing the re-ult of at moral ale with the nature of the act - hats

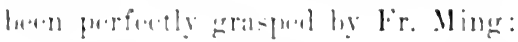

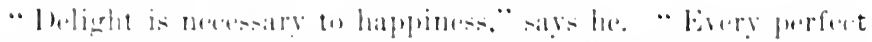
action is followent hy delight: for it lies in the nature of at fateults that, having diecharged the function for whieh it was made.

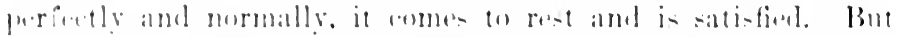
for the very reaten that delight is not the action itswlf. but merely its result or concomitant, it canmot be an enerntial con-tituent of happines: it is hut one of its neesesary attribute-

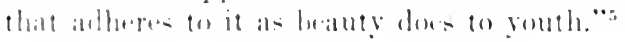

This calpital thaw of hedoni-m might have heren, however, more strongly insi-ted upun.

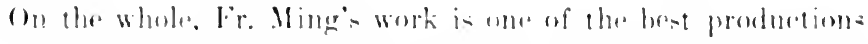

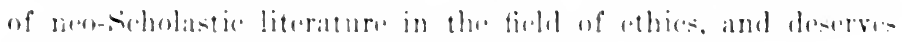
the caroful study of all inderestent in moral philwophy.

In the field of Xatural 'Theolugers an important contribution!

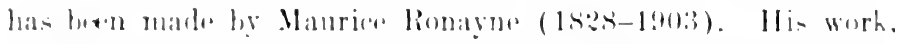

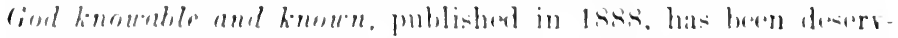

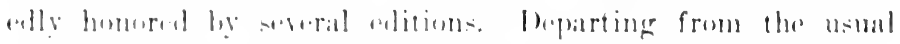

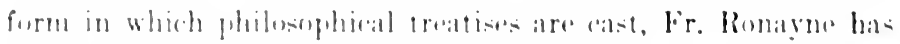
mande un of the dialogene with the greateat skill. The interlocu-

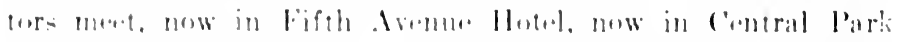

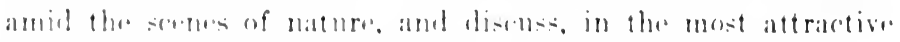

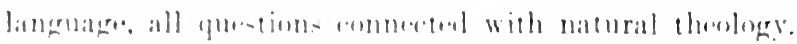

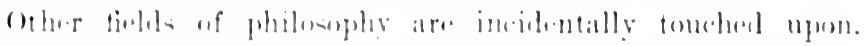

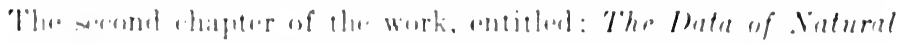

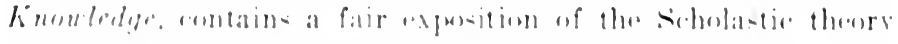

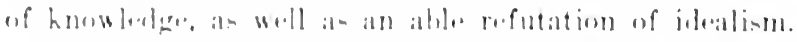

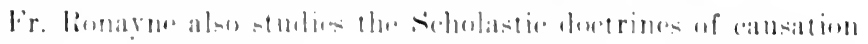

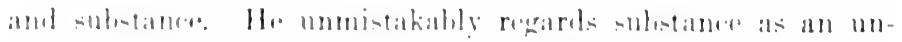

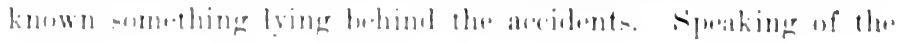

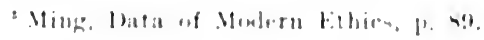


phenomenalists, he says: "They do not take gold for silver, nor silver for copper, because these metals differ in the phenomenon of color, but because of something beneath that color and partially manifested by it."

Mention must also be made of Amilius de Augustinis, for his work, De Deo Uno secundum naturam (1884), and James ('onway (1849-1905), professor in St. Louis University, and author of a small volume entitled, The Fundamental Principles of Christian Ethics, which belongs to the series, Catholic Summer and Winter school Library.

Thomism has also found distinguished representatives in other religious orders. A name that readily comes to one's mind at the consideration of Scholasticism outside of the Society of Jesus is that of Brother Azarias, of the Christian Schools.

Brother Azarias, born Patrick Franeis Mullany (184i-1893), is one of the most distinguished-the most distinguished perhaps-of our Catholic writers. Although known chiefly as a literary eritic, he is the author of several philosophieal works well worthy of attention. Whether he is a great philosopher or not, I will not here decide. About his originality as a thinker, no doubt can be entertained. In his Essays philosophical, he gives the following principle as the first principle of philosophy: "God actualizes Cosmos by the Word, and completes its end in the Word." Which he unriddles in the following manner:

"In the term God, we have the subject of Theodicy and Natural 'Theology.

"In the term Cosmos, we have the idea that gives us the ideas of space and time, with all their concomitant ideas of number, extension, mathematies, natural history and physies.

"In the term the Word is contained the type of creationthe basis of history-the ideal of literature and art.

"In the term completes its destiny in the Word, we have the whole supernatural order-a Chureh, the means of sanctification.

"In the term actualizes, we have the idea of pure and supreme

- Ronayne, God Knowable and Known, p. 32. 
cause expresed, and the real relations of the creator to his creation. $\cdots$

Brother Azarias thus regards philosophy as embracing all human knowledge, natural and snpernatural. 'This view unequivocally separates him from the neo-seholastics, to whose school, it is true, he does not profess to belong:

"To helong exelusively to any school of thought," says he, " is to shut out from one's soul all truth hut that which presents itself under a griven aspect. It is to be continually asking the question, ('an any good come out of Xazareth? And ret good (an enue out of Sazareth; every Sazareth of thought has its own leson to teach us if we willingly learn it and put it to profit."

Althomgh Brother Azarias is not, strictly speaking, a scholastice, he has done good service to the ante of nero-scholasticism in this country by his larmed treatises on Modiaval philosophy. 'The assay, Aristotle and the Christian church. contains excellent pages dealing with the spirit of the seloogmen. Allort the lireat, St. 'Thomats and Roger batcon are chiefly dealt with. The anthor alearly shows that the Modianal writers were not servile followers of Aristotle, but that they thought and wrote in the spirit of real philosophers. How Brother Azarias regards the sebolastie revival is alearly indieated in the following statement :

"Finally, there is the intellectual atmosphere of the day in which thought lives and moves. It cammot exist without breathing this air. If the past is ruvivel, it lives only in proportion as it is brought to bear upon the present."

Brother C'hrysostom, horn Joseph J. Comlan, in New Ilaven (connecticut), in 1863, and actually professor of philosophy in Manhattan ('ollege ( New York), is more strictly a Sicholastic than Prother Azarias. He is the author of two brief courses of

'Brother Azarias, Essaye Philosophical, pp. 158-159.

"Ihid., p. 85.

- Mrid., p. s.5. 
Scholastic philosophy. One of them, the Elementary C'ourse of Christian I'hilosophy, is an adaptation of a Freneh work written by Brother Louis of Poissy, and, in spite of its coneise form, is one of the most instructive manuals published in this country. 'The other course, written in Latin, was published in 1897, under the title, Elementa Philosophice Scholastica. It deals with logic, ontology or general metaphysics, and cosmology, and is chiefly inspired by the works of Zigliara, Liberatore and Farges.

Brother Chrysostom has also defended the eause of Scholastic philosophy in several review articles. The most important of them appeared in the Philosophical Rerieu in 1894, and was devoted to the study of the theistie argument of St. Thomas.

In the Dominican order, we find a single work worthy of mention; but this work is one of the best studies written by American neo-Scholastics. La Philosophie en Amérique depuis les origines jusqu'à nos jours of Father Edward Gregory Laurence Van Becelaere (born 18\%2), was published in 1904, after having appeared in the form of articles in the Revue Thomiste. As a study of the varions eurrents of thought which have dominated our country, Fr. Van Becelaere's work, despite its brevity, is the best work we possess. Some aspects of American thought have been, however, entirely overlooked or too briefly treated. A history of American philosophy ought certainly to contain a chapter on Pragmatism.

Fr. Van Becelaere's volume is eompleted by an appendix dealing with Catholic philosophy in the United States. 'This part of the work of the learned Dominican contains interesting details on the neo-Scholastic revival in this country.

Scholastic principles have also found able defenders in our secular clergy.

Gennaro Luigi Vincenzo de Concilio, born at Naples (Italy), in 1835, and for a short time professor of dogmatic theology, logic and metaphysies in Seton Hall College, South Orange, New Jersey, published, besides a text-book on Scholastic philosophy (Elements of Intellectual Philosophy, 18r8), a theo- 
logico-philosophical work, entitled Catholicity and Pantheism (18it), in which he regards Pantheism as the necessary result of Protestantism, ${ }^{10}$ as the universal error in time and space. ${ }^{11}$ "Every particular error, says he, has either fallen into Pantheism, or disappeared altogether. ${ }^{\prime 2}$

John (imeiner, born in Baernau (Bavaria), on December 5, 184\%, and, for seven years, professor at St. Francis Seminary (Milwaukee), and at St. 'Thomas Seminary (St. Paul), has published several philosophical works, in which, in harmony with Le XIIl's formula: vetera novis augere. he endeavors to harmonize the Scholastic teachings with modern science, and mereilessly discards all tenets which cannot be easily harmonized. In a remarkable little work, entitled Medional and Morlern C'osmology (1891), he denounces some theories, usually defended in ('atholic text-hooks, and which, in his opinion, reflect but little credit upon ('atholie thinking. Among the doctrines thus stigmatized is the theory of Matter and Form.

John T. Driscoll, born in Albany (New York), after stulying in Manhattan College and Troy Theological Seminary, completed his studies in the Catholic Eniversity. IJe has taught philusophy for several years in the Theological Seminary at Brighton (Massachusetts) and has enriched American neoScholastic literature with two excellent works: A Treatise on the Iluman Sioul, published in 1898, and (iod, which appeared two years later.

The method followed in these two works may be characterized as experimental and comparative. In the Treatise on the Il uman Soul, the author starts from the facts of our consciousness: sensations, sentiments, ideas, memories, judgments, reasonings, etce, which are "as true and real as the circulation of the bleot, or the existence of physical or chemical forces."

${ }^{10}$ ('f. Catholicity and Pantheism, p. 21.

"Ibid., P. 14.

12 Mid., p. 20. 
From such ficts of experience he derives, by a proeses of reasoning, his system as to the nature of the soul.

In agreement with the Scholastic teaching, he proves the principle of our bodily and mental energies to be one and simple, spiritual and immortal.

Scholastic psychology is studied in eonnection with all allverse teachings. All ancient and modern systems concerning the principle of life in man are discussed with a remarkable erudition and brought face to face with the Scholastic theories.

The inadequacy of Materialism and Positivism is very ably pointed out. The work also contains valuable chapters on the diverse forms of Pantheism and Monism. Some conclusions of the author do not seem, however, perfectly justifiable. He rejects, for example, Kant's opinion that we know phenomena only, and not the thing-in-itself, on the ground that such an opinion is opposed to the data and methods of physical science:

"science," says he, "deals with real things. The axioms and rules of mathematical science must be verified in concrete objects in order that the calculations founded upon them may have any validity. The same is true of chemistry and of physics." ${ }^{13}$

This objection would be perfectly valid if Kant failed to recognize in the phenomena an objective element. But this is not the case. The phenomenon is subjective in so far as the outside reality, the object, is clothed with the conditions of our sensibility and of our understanding; but it is also objective, inasmuch as it is caused by the thing-in-itedf.

We are, with regard to the thing-in-iticlf. in the same position as a person with a pair of colored glasses would be with regard to the color of a landsape. Mlthough such a person would never know the color of the landscape as it is in itself, he would nevertheless be able to possess a real science of color, to formulate laws, which would be conditioned hy the object and in harmony with its manifestations.

${ }^{13}$ Driscoll, The soul, p. 40. 
The aim of the treatise on God is thus set forth in the preface:

"The considerations adduced are the heritage of christian Philosophy hamded down by the pens of st. Augustine and st. Thomals. The marvelous alvanee in the seiences furnishes increased data for argument and illustration. The question is considered under all aspects. All sourees of knowledge are investigated. History, Language, Psychology, Ethic's, the Physical sciences, each comes with its special testimony. The aim is simply to collect the data and show their bearing on the idea of fiod: to answer the question: What is meant by ciod, and has the ithat of (iod an objective validity? " 14

Like all modern scholastice, Mr. I Priseoll rejects the ontologinal argument, in its original shape as well as in the form it has assumed in the hands of the neo-Ilegrelian school. Ho also rejects the theory of direct intuition of the I)ivine Being, advorated by Harris, Wilson, Caird, and other non-('atholic writers of the present day. He regards as valid the arguments from universal consent, from the moral life, from the contingency of living beings, from a first cause, from motion, from the order of the universe. He also aecepts the old argument drawn from the nature of truth, first proposed by st. Augustine, and recently revived by Josiah Royece. He clearly points out, however, that, in the hands of $\mathbf{M r}$. Royere, the argument loses its value and involves a petitio principii:

"What is (for Royece) the trist of subjective truth? Sot ronformity with external reality. This he expressly rejects. But conformity with a higher intelligrence. Henee he is a disciple of Berkelere. Hence he falls into al petitio principii. He sets

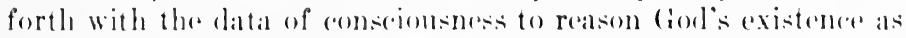
absolute Truth. Yed he postulates the existence of the AllLnower or All-kinfolder to justify the veracity of the data. This was the mistake of Descalete. "15

Mr. I) riveoll, als we have seen, has been a student in the ('atholic Eniversity. This miversity, the first stone of which was

"Hriscoll, (iod, p. 3.

stlid., p. i!). 
laid on May 24, 1888, in the presence of Cardinal Gibbons, four archbishops, twenty-one bishops and numerous eminent men, among whom President Cleveland, has contributed to neoScholastic literature numerous articles in a periodical publication, the Catholic University Bulletin. The most eminent contributors have been Edward $\Lambda$. Pace, Edmund T. Shanahan and William Turner (cf. Bibliography).

Mr. Turner has also published valuable artieles about the Middle Ages in other reviews, such as the American Catholic Quarterly, the Philosophical Review and the New York Revieu. His greatest title to the gratitude of all students of philosophy is, however, his History of Philosophy, published in 1903. 'This work has been greatly praised, and with justice. It exposes with a remarkable erudition the philosophical systems of aneient and modern times. More perfectly than any other similar work, it condenses, in a few pages, the spirit and the doctrines of each philosopher it studies. Mr. Turner devotes a special attention to the study of the Middle Ages. Of the $6 r 4$ pages, which the work contains, 185 are devoted to Scholastic philosophy.

Mention must be made also of two important works written as dissertations for the Doctor's degree. 'The first of them is Religion and Morality, written in 1899, at the Catholic University, hy James J. Fox. The work, inspired by the purest Thomistic ethical prineiples, strives to base upon history and reason the thesis that religion and morality are necessarily connected. The other work, The Knowableness of God (1905), written at Notre Dame University by Matthew Schumacher, is one of the most important contributions of neo-Scholasticism to the field of Natural Theology.

Section 2.-The Neo-Scholastic Revival in Canada

The philosophy of St. Thomas Aquinas forms the basis of all philosophical teaching in the Catholic institutions of Canada.

A long time before the promulgation of the encyclical Eterni Patris, 'Thomism was already taught in the College of St. Hya- 
rinth. One of the professors of this college, Mgr. Desaulniers, wrote a complete course of scholastic philosophy, inspired by St. Thomas and liberatore, which hat never been published.

The Iniversity of Ottawa, directed by the Ohlate Fathers, likewise follows the teachings of the Angelie loetor. It possises an Academy of St. Thomas in which a thesis, in harmony. with the Scholastic principles, is defended every week.

The most important center of Thomism in Canada is, however, the Iniversity Laval, in Quebee. As early as 1859, this miversity adopted Zigliaras summa Philosophica as a textbook in philosophy. In 18s.t, the Faculty of 'Theology decided to study St. Thomas in the Summa Theologica itself, which has been, since that time, the manual of theology.

The Thomistic movement in Canada has also given rise to a fow interesting works. The first in date is the volume entitled, Philosophy of the Bible lindicated (1si6), written by Cornelius O'Brien.

(omelius o'Prien, born on May 4, 1843, in New Glasgow (Prince Edward Island), cducated at St. Dunstan's Collece ('harlottetown), and at the Propaganda (Rome), ordained prixst in 1851, professor in St. Dunstan's College, orator, theologian, novelist, poet, has oceupied the archiepiscopal see of Halifax from 1883 till his drath, on March 9, 1906.

His: "Ihitssophy of the Bithe" consists of three parts. In the first part, entitled Satural Thoology. the author proves the existenee of a Supreme Bring by the well-known Scholastic arements from a first cause. from the order of the world, and from the universal ansent of mankind. Ho demonstrates that this Suprene being, or foul, existing by neessity of nature, is infinitely perfect, the creator and ruler of the physical world.

In the serend part, entitled l'sychology. he proves the soul 10 be simple, spiritual, immortal, mblowed with free will, and reatod immerliately ley lion when it is to be infused into the berly.

o'Brim differs fom most molern defenters of Thomism with 
regard to the origin of our ideas. As he insists more than Scholastics usually do, upon the activity essential to substance, ${ }^{16}$ and maintains not only that substance acts, but that whatever acts is a substance, ${ }^{17}$ he is led to the assertion that the soul is " a force the very essence of which is that it should think, understand, know, will,"18 that it must therefore necessarily know its own existence and something about happiness, and possess, by the same fact, two ideas which are, if not innate, at least coeval with the soul.

The third part of the Philosophy of the Bible is devoted to the study of certain questions which have an intimate connection with ontology and have not been studied in the two preceding parts: space and time, certitude, religion, revelation, the relation of faith and reason, ete.

O'Brien is an enthusiastic admirer of Mediæval philosophy. He is convinced that many "professors who are now extolled as prodigies of learning would, had their lot been east in the oftreviled middle ages, have been considered noisy school-boys." "19

In harmony with the Scholastic principle of the unity of truth, he maintains that there can be but one true system of philosophy, and goes even farther than most of the early neoScholastics in his contemptuous disrespect for modern thinking.

"Let it be understood from the outset," says he, "that we deny the title of Philosopher to the founders of schools of error. . . The man who, as a general rule, blunders in the art he professes to follow, is not called a tradesman, but a botcher; why, then, all meaningless seribblers Philosophers? They are literari fungi. ${ }^{20}$

And if we wish to know more definitely who those " meaningless scribblers" are, we shall perhaps be astonished to find among them:

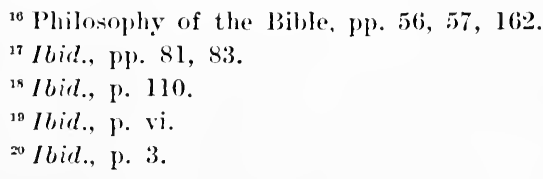


"Philosophic quateks, sleh als Ilegul, Kant, I)arwin, and id gerus omne;"1

"spinoza, who gave such a proof of mental aberration that a school-boy who would be gulty of similar contradictions, would most surely be doomed to lose his first holiday, and obliged to write five hundred times: Idem non potest simul esse et non esse:"2

"The disciples of the transcendental German sehool, who, lulled into a semi-somniferous state, by lager beer and strong (igars, talk misty things which they eall transcendental." ${ }^{\circ: 3}$

Louis 1. Paquet, actual president of the Eniversity Laval, published, in 188s, in the review C'anada français, of (Quebec. an important article, entitled: Rosmini et son systènc, in which he refutes the Rosminian doctrines by the principles of Sicholistic philosophy.

I fow years later, Mgr. Paquet published the first volumes of the work upon which his fame (hiefly rests, his l)isputationes theslogicor. which form a learned eommentary on st. 'Thomas's summa Theologica. The first edition of the work was published in (quebee between the rears 1893 and 1903. A reeond edition is now being made at Rome.

Mention must also be made of Brother Symphorien-Louis, of the ('hristian Sichools, who published in Montral, in 190.5, a teat-besk on sicholastic motaphysies (I'récis de Métaphysique).

Among the recent defenders of Thomism in canadia, no one perhaps has served the sicholastic cause with a greater distinetion than Alexander Macdonald, actual Vicar cieneral of Antigonish and rector of sit. Andrews (Nova Seotia).

Born in s. IV. Mabem, (ape Breton, on February 1s. 185s, Mr. Marelonald studied at St. Francis Xavier college (. Antigronish) and at the Propagranda, in Rome, where he was the disciple of the famous ('ardinal satolli. After being ordained, in $1 \mathrm{~s} s \mathrm{t}$, he taught philosephy for nincteen yoars in st. Francis

"llid., p. Sit.

$=$ Ilicid., p. 42.

${ }^{25}$ Ibid., p. 1!). 
Xavier College. During this time he showed himself a valiant champion of the Scholastic principles in numerous articles, which appeared in the Casket, of Antigonish, or in other periodical publications (cf. Bibliography). Mr. MacDonald is also the author of several important works in theology, such as The Sacrifice of the Mass (New York, 1905), The Sacraments (New York, 1906), with which this essay is not directly concerned. 


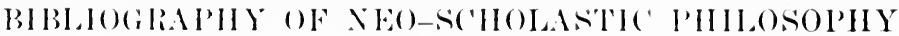

\section{P'Enonicil Pimicitioxs}

Annalcs de Philosophie chrétienne. Paris, since 1830.

Bölcseleti-Folyótrat. Budapest, since 1886 .

Divus Thomas. llacentiar, 1879-1905.

Jahrbuch für Philosophie und speculative Theologie. Paderborn, since 1887.

Vew York Rericur. New York, since 1905.

La Pensé contemporaine. Paris, since 1903.

Philosophisches Jahrbuch. Fulda, since lsss.

Rerista Luliana. Barcelona, since 1901.

Rerue Véo-scolastique. Louvain, since 1 s:4.

Rerue de Philosophie. Paris, since 1900.

Reve des sciences philosophiques et thélogiques. Kain, since 1907.

lieve Thomiste. Paris, since 1893.

saint-Thomasblatter. Regenshurg, lsss ff.

\section{SEPARATE: WORKS}

VAx Der Aa, S.J., J. Prielectionum Pliblosophia Scholastica brevis conspectus. Lovanii, Fonteyn, 1s86, 2 ed., 1888.

Anfrarb. Edition Cousin. Paris, 1836; Paris, 1849-59; Migne, Patrologia latina, vol. 178; Sic et Non, Marburgi, 185l.

Anrovis, Joww. Ansolm Cant: de mutuo fidei ate nationis consortio. Wurzhurg, 1864.

Anamson, liomert. Loger Bacon. An Address. Manchester, $18 j 6$.

Adeobstes, Alertelts. Die Philosophio und Cultur der Nouzeit und die Philosophite des hl. Thomats von Aquino. Koeln, lsist.

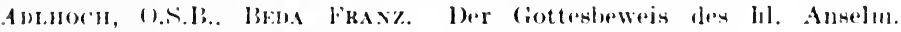
Philos. Jahrb., 1895-97.

Prafationes ad artis -chalasticar inter ocedentales fata. Brunae. Jast.

Zur wimenichaftlichen lerklïrmug dew Atheismus. Philos. Jahrb., 190.5.

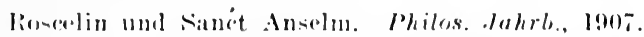

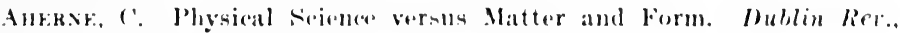
1899.

Alurke Fredegis von Tours. Leiprig, 1878.

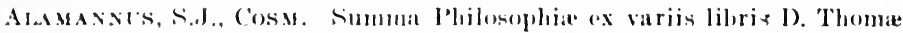
Ay. in ordinem enrsus philuephici acommodata. Editio juxta glam. Pari-iensem adornata ab A. Bringman, S.J.; Paris, Jathirlle lix, lingo fr.

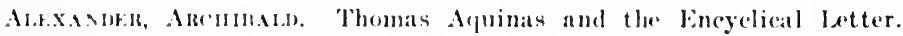
I'rinerem liet., March, liso. 
Alvarado, O.P., Fraxcisco. Cartas del Filósofo Rancio. 2 vol., Madrid, 1851-52.

Alvarez, Exrique. Elementos de Filosofia y Moral. Bogotá, 1884.

Angelert. Rosmini è panteista? Risposta del Sae. Prof. Angeleri all'opusculo degli Universali del P. M. Liberatore. Verona, 1882.

Un articolo della Civilta cattolica contro un opuseolo, Rosmini a panteista? esaminato dall'autore dell'opuseolo medesimo. 1882. Avgelicus, 1. A végtelen. Böles. Foly., 1891.

Axin̈uper, G. Az aktus és a potenciaról. Bölcs. Foly., 1896.

Arbors y Tor. Ensayo de Física y Química transcendental. Bareconal. 1879.

Arvilz, Marcelino. El Instituto superior de Filosofía (Escuela de Santo Tomás de Aquino) en la Universidad Catolica de Lovaina. Madrid, 1901.

La Neo-Escolástica al comenzar el siglo XX. Ciudad de Dios, 1902.

Los fenómenos psicológicos. Cuestiones de psieología contemporánea. Madrid, Tip. del Sagrado Corazón, 1903.

Elementos de psicología fundada en la experiencia. I.: I.a vida sensible. Madrid, Tabares. 1904.

Abuso de las metaforas en las ciencias psieológicas. Ciudad de Dios, 1905.

Mons. D. Mereier, Primado de Bêlgica. Su obra filosófica. Ciudad de Dios, 1906.

Pragmatismo y Humanismo. Cultura española, 1907.

Asin y Palacios, Miguel. Algazel. Dogmática, Moral, Ascétiea. Con prólogo de Menendez Pelayo. Zaragoza, Comas, 1901.

El Averroismo teológico de Santo Tomás de Aquino. Zaragoza, 1904.

Sens du mot "Tehafot" dans les æuvres d'El-Ghazali et d'Averroes. Traduit par J. Robert, Alger, Jourdan, 1906.

La Psicología según Mohidin Abenarabi. Paris, Leroux, 1906.

la indiferencia religiosa en la España musulmana según Abenhazam, historiador de las religiones y las sectas. Madrid, Inp. Iberica, $] 907$.

Deseription d'un manuscrit arabe-chrêtien (Extrait de la Revue de l'Orient elorétien, 1906). Paris, 1907.

D’Assandy, Octave. Albert le Grand. Paris, 1870.

Astronorf, J. Introductio ad intelligendam doctrinam Angelici Doctoris. Romar, lss4.

Arbry, J. B. Molanges de philosophie catholique, le cartésianisme, le rationalisme et la scolastique. l'aris, Retanx, 189:5.

DE Argestixis, S.J., Aemilius. De Deo Uno seeundum Naturam. Prabetiones Scholastico-Dogmatice quas in Collegio SS. Cordis ad Woodstock habebat; Neo-Eboraci, Benziger, 1884. 
Aveswg, Fraxces. (hrintian Philosophy. Dublin lier., 1902.

The Annosticion of Fath. Mublin lier., la03.

The Philosophy of Herbert speneer. Dublin lier., 1904.

The Langulage of the Schools. Lublin lite., 1904.

Philosophy, Gueen and llandmaiden. Dublin Rer., 190.5.

The Immortality of the Soul. London and Edinburgh, Sands, 190.).

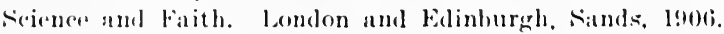

The fiod of linilosophy. London and Edinlourgh, Sands, 1906.

The Progress of Thought and the Catholie Faith. Amer. Cath. (Quort., 1901\%.

The Thought-lialue of Proof: an Eirenieon. Amer. C'ath. Quart., $190 \%$.

Azamas, Bowther. The Development of Old English Thought. 3 ed., Ninw York. Appleton, 1s!90.

Aristotle and the Christian C'hurch. London. Kegan, Paul \& Co., jisis?.

Mediaval lniversity life. Amer. ('ath. Quart., 1s93.

Cniversity collewes: their origin and their mothod. Amer. Cath. Quart., 1s93-4.

Essays philosophical. ('hicanor) Jis!g.

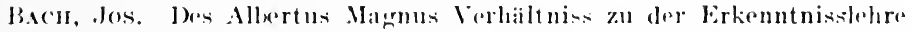
der Griechen, liomer, Araber und Juden. Wien, Brammuler. 1 sisi.

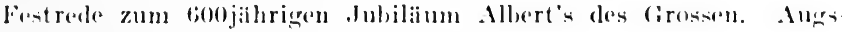
buri, $18 \times 1$.

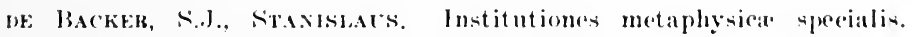
Paris, Delhomme \& Briguet, 1s99 1905.

Bacos, liocike adit. Iobb, Opun majus, London, 1733: ed. Brewer. ()pus tertium, ()pus minus, (ompendium Philosophiar, London. 1s.s?: ad. Bridgers, Opus ma jus, Oxford. 189\%.

DF: Barts, Matrice. lou bases do la morale at du droit. Paris, Alean. la!): Sian. ly Gonzalez ('arreño, Madrid, 190\%.

Batemker. ('ikgexs. Das l'roblem der Materie in der griechischen

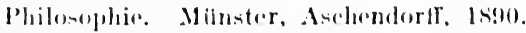

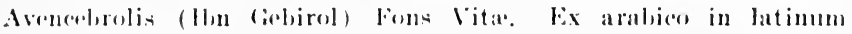

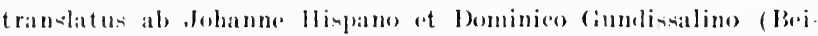

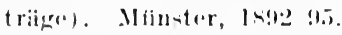

Bin Tractat genen die Amalrieianer ans dem Anfang des Xlll. Jahrh. Paulurborn, lis!3.

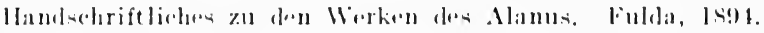

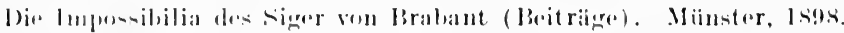

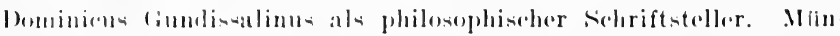
ster, Anchemertor, limos.

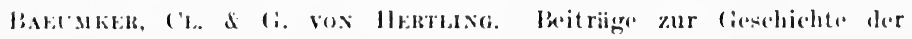


Philosophie des Mittelalters. Texte und Untersuchung. Mïnster, $1891 \mathrm{ff}^{1}$

BAindot, H. A. Aleuin der lehrer Karls des Grossen. Lauenburg, 1861.

BAIlle, Lours. Science et Religion. Qu'est-ce que la science. Paris, 1906.

Genese des premiers principes. Rev. de Philos., 1907.

La question du mixte. Rev. de Philos., 1907.

Ballerixi, Giuseppe. Analisi del socialismo contemporaneo. 4. ed., Siena, s. Bernardino, 1901; Span. by Crusat de Eguilaz, Madrid, Rojas, 1902.

Il dogma Euearistico. La scienza incredula e la filosofia tomistica. Monza, 1900.

Il principio di causalita e l'esistenza di Dio di fronte alla scienza moderna. Firenze, lib. Fiorentina, 1904; 2. ed., 1908.

La conoscenza dell'al di la. La dimostrazione dell'al di la. Scuol. c., 1907 .

Ballou, H. Philosophy and doctrines of Erigena. Univ. Quart., vii, 90.

Balmes, Jaime. El Criterio. Madrid, 1842; French by E. Manec, Paris, 1850; Engl., New York, 1875; Engl., by Wm. McDonald, Dublin, 1882.

Filosofía fundamental. 4 vol., Barcelona, 1846; 7. ed.. 1898; French by E. Manec, 3 vol., Paris, 1852; Engl. by Henry F. Brownson (with Introduction by O. A. Brownson), 2 vol., New York, 18; German, by Lormson, 4 vol., Regensburg, 1855-56.

Curso de filosofía elemental. Madrid, 1847; 9. ed., Barcelona, 1899. ('ursus philosophiæ elementaris. 2 vol., Bareinone, Brusi, 1848-50. ('artas á un escéptico en materia de religión. México, 1849.

Selecta colección de eseritos del Sr. Dr. D. Jaime Balmes. México, 1850.

Eseritos postumos der Sr. Dr. D. Jaime Balmes. Mexico, 1851.

Baltiasar, Nicolas. Le Problème de Dieu, d'après la Philosophie nouvelle. Rev. Néo-scol., 1907-8.

Balts, Crbarx. L'idealisme de saint Augustin et de saint Thomas d'Aquin. Rev. bénéd., 1897.

Dieu d'après Hugues de St. Vietor. Rev. bénéd., 1898.

Une apologie protestante de saint Thomas d'Aquin. Rev. bénéd., 1898.

Baricit, Carl Sigmund \& Jomann Wronel. Bernardi Silvestris De Mundi Universitate, sive Megacosmos et Microcosmos. Innsbruck, 1876.

Harias, l'Bother. St. Thomas's Latest Critie. Amer. Cath. Quart., 1885.

The Force of Prineiples. Amer. Cath. Quart., 1890.

'The works belonging to this eollection are marked: (Beitrige) in our Bibliograplyy. 
Barbras, Anbrert. Esse formale estne rei intrinsecum an non? Pla. centiar, 18st.

Positivismus ac nova methodus psychologica professoris P. Siciliani. Animadversiones critica. Placentia, $185 \%$.

De signis mathematieis adhibendis in logiees traditione. Dir. Thom., 1890-91.

Bardexnewk. Die pseudo-aristotelische Schrift ueber das reine liute bekannt unter dem Namen Liber de Causis. Freiburg-i-13., lske.

Baroowicz, Leo. Die rationale Schriftanslegung des Maimonides und die dakej in Betracht kommenden philosophischen Anschaungen desselben. Wien, 1893.

Barox. Die Bedeutung der Phantasmen fiir die Entstehung der Begriffe bei Thomas von Aquin. Mïnster, 1903.

Bakoxr. Ag. San Tommato e la filosofia morale. Nola, 1889.

DE LA BARKe. S.J. Certitudes scientificues et certitudes philosophiques. Paris, Hloud, 1897 .

Lordre de la nature et le miracle. Faits surnaturels et forces naturelles, chimiques, psychiques, physiques. Paris, Bloud, 1899.

La vie du dogme eatholique. Autorité, evolution. Paris, lethielleux, 1900 .

Barky. Wilatam. The New Birth of ('hristian Philosophy. contemp. lier., Issi3.

Batracisis, Fraxc. Institutiones philosophicie secundum s. Thomas Aq. doctrinam. 3ia. impressio, 3 vol., Bologna, 1890.

Batrix. Lacte et la puissinee dans Aristote. Paris, 1900.

Batmaxx, J. J. Die statslehre des hl. Thomas von Aquin, des grossten Theologen und Philosophen der katholischen Kirehe. Leiprig. 1873.

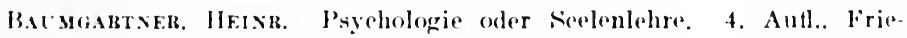
burg-i-B., llerder, ls!m!

liarmgartigr, Matruias. Die Erkenntnisslelure des Wilhelm ron Auvergne (Beitrige). Miinster, 1893.

Die Philosophie des Alanus de Insulis, im Zusammenhange mit den Anschauungen des 12. Jihrhunderts dargestellt (Beitriage). Miinster, lis?ti.

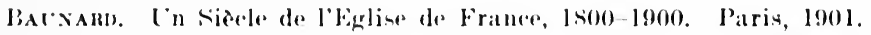

vox lisk, Ferdo, ('uk. Die christliche lehre von der Versöhnung. Tiibingen, 1838.

Bark, Josfin. Die actuell unendliehe Kahl in der Philosophie und in der Natur. Philos, Jahrb., 1900.

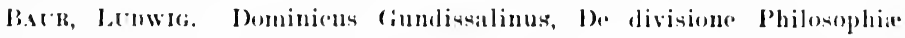
(Beit rigene). Mlinster, 1!103.

Substunalegritr und Aktualitat-philosephlie. Philos. Jahrb., 1904.

ne: Batarer, ('a teriori". Rer. de lohiles., l!ats. 
Penussire, Emile. D. J. Balmes. Rev. Moderne, 1869.

Beccaria, P. Saggio di filosofia italiana e tomista. Torino, 1889.

Saggio di filosofia morale. S. Benigno, Canavese, 1891.

van Becelaere, O.P., L. A Summary Exposition of St. Thomas Aquinas's Philosophy of Knowledge. Philos. Rev., 1903.

La philosophie en Amérique depuis les origines jusqu’a nos jours (with Introduction by Josiah Royce). New York, Eclectic Pub. Co., 1904.

Becker, Jos. Blas. Der Satz des hl. Anselm: Credo, ut intelligam in seiner Bedeutung und Tragweite. Philos. Jahrb., 1905-6.

Beder. De Anselm. Cant. Lugd. Batav., 1832.

Beer, Peter. Leben und Wirken des Rabbi Moses ben Maimon. Prag, 1834.

Beqix. Sciences naturelles du moyen âge. Paris, 1851.

Benisci, A. Two lectures on the life and writings of Maimonides. London, 1847 .

Benyícs, J. A keresztény szocializmusról. Budapest, 1905.

Benzoni, R. La filosofia dell'Academia Romana di San Tommaso. Rev. ital di filos., 1886.

Bergemand. Der scholastische Staatsgedanke. Ph. Wochensehrift $u$. Litteratur-Zeitung, Bd. 3, 1906.

Bergon y Vasquez, A. Estudios críticos acerca de las obras de Sto. Tomás de Aquino. Madrid, 1899.

S't. Bernard. Opera, Paris, 1839. Lyon, 1845; ed. J. M. Mandernach, tom. 1, Trev., 1861; French by A. Ravelet, Paris, 1865; by Charpentier, 8 vol., Parıs, 1873; Swedish by H. Wieselgren, Stockholm, 1844 .

Bernies, Victor. Immatérialité et matérialité de l'âme humaine. Rer. de Philos., 1901.

Spiritualité et immortalité. Paris, Bloud, 1901.

L'Abstraction scolastique et l'"Intellectus agens." Rcv. de Philos., 1904.

L’origine des idées. Rev. de Philos., 1906.

Bertincmer. Histoire de saint Bonaventure. Paris, 1858. German, Regensburg, 1863.

Berther, O.P., J. J. Tabulæ systematicæ et synopticæ totius Summæ Theologicæ justa ipsammet Doctoris Angelici methodum strictius et clarius exacte. Friburgi Helvetiorum, ed. altera, 1893.

Tabulie systematiex et synoptica totius Summa contra Gentiles. Paris, 1900.

L'étude de la Somme Théologique de saint Thomas d'Aquin. Paris, 2. ed., 1906 .

Bentixaria, F. 11 problema capitale della Scolastica. Riv. ital. di filos., $1 \times 89$. 
Besse, (Clesert. Deux centres du mouvement thomi-te, Rome et Lou vain. Paris. letouzey \& Ane. 1902.

Philosophie et Philosophes. Essais de critique philosophigue. Premiere série. Préface par l'abho (inibert. Paris, lethielledux, 1904.

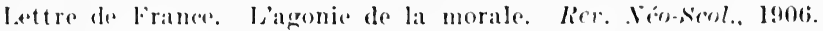

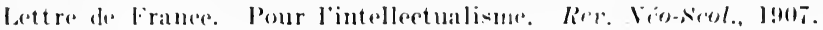

Brssukr, s.l., I. Storungen im seelenleben. Freiburg-i-B.. Herder, 190.5.

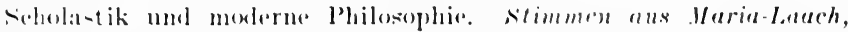
$191 \%$.

Barntese. Jensignement de la philosophie thomiste a l'universite atholique de Louvain. Louvain, 18si.

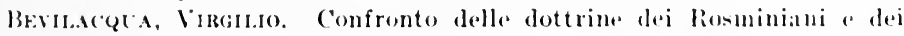
Neotomisti. Vienza, 1882.

Brysexs, J. Th. De Ontwikielingsgeschiedenis der organisehe soorten. van het standpunt der scholastieke Wijsbegeerte. Leiden, Theonville, 1902.

(ritriologie of de leer over watheid en zekerheid. Leiden, Theonville, 19013.

Entologie of Alyemerene Metaphysical. Amsterdam, Van Langenhuysen. 1!nt.

Algemeene \%ielkunde. Amsterdam, 1906.

Theodicee of naturlijke (iodsleer. Erste Deel: (iods bestaan. Ther orieen, Codsbewijzen. Amsterdam, 1907.

Biaven, ().P., Rasmovo. De Constitutione monarehiea Eeclenia et de Infallibilitate lomani Pontificis juxta 1). Thoman Aquinatis ejusque scholam, Romar. 1870.

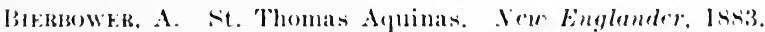

Bicicet. Philosophes modernes et philosophes reolastiplues. Sicience frth., lagt:

Brmakr, F. Az idealizmus tïrtencte. Budapest, 1900.

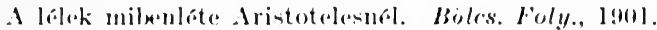

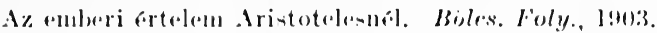

billia. I. .I. Li alcume contralizioni del neotomismo. luoro Risergimento. 1s!9-9s.

L'eviglio di s. Agostino. Torino, 1s!99.

Binkotn, J. (i. F. De Analui ('antuarionsis proslogio ot monologio.

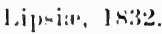

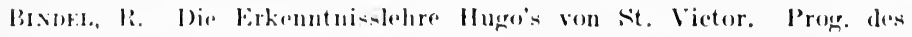

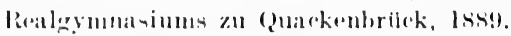

Brtantr, H. Dia loben des Peter Alsilnrd. \%eritsch. f. histor. Theol., listi?.

Die Schriften. der philowephisehe standpunkt, und die lithik des Peter Abiilard. \%eitsch. f. histor. Theol., lsio. 
Blanc, Elie. Traité du libre arbitre. Lyon, 1886.

Traite de philosophie scolastique. Lyon, Vitte, 1s89; 2. ed., 1893.

Histoire de la philosophie et particulièrement de la philosophie contemporaine. Jyon and Paris, 1896.

Mélanges philosophiques. Lyon and Paris, 1897-1900.

Opuscules philosophiques. Jyon and Paris.

Manuale philosophiæ seholasticæ. 2 vol., Lyon, Vitte, 1901.

La Vérité. Sa définition et ses espèces. Rev. de Philos., 1901.

Dictionnaire de philosophie aneienne, moderne et contemporaine. Paris, Lethielleux, 1906.

La foi et la morale ehrétienne. Paris, Lethielleux, 1907.

Blanc, Elie, axd Hugues Vaganay. Repertoire bibliographique des auteurs et des ouvrages contemporains de langue française ou latine. Paris, Vic et Amat, 1902.

Braxche, A. Sur l'usage de l'évidence comme suprême critérium. Rer. thom., 1903-4.

de Blancie-Raffin, A. Balmes, sa vie et ses ouvrages. Paris, 1843; German by F. X. Karker, Regensburg, 1852.

Bloch, Morse. Le livre des préceptes par Moise ben Maimon, publié dans l'original arabe. Paris, 1888.

Boedder, S.J., Bernard. Natural Theology. New York, Benziger, 1891; London, Longmans, Green \& Co., 2d ed, 1899.

Psychologia naturalis sive philosophia de anima humana. Friburgi, 1894 ; ed. $4 ., 1906$.

Theologia naturalis sive plilosophia de Deo. Friburgi, 1895.

Borifa, L. C. Il misticismo di s. Bonaventura, studiato nelle sue antecedenze e nelle sue esplicazioni. Torino, Clausen, 1901.

Bonacina, C. Dottrina di san Tommaso d'Aquino sul coneorso generale di Dio nell'axione ereata. Milano, 1889.

Bondteli. La psicologia di D. Mercier. Riv. filos., 1900.

S. Boxavestura. Opera; ed. A. C. Peltier. 15 vol., Paris and Besancon, 1864-71; edita studio et cura PP. Collegii a $\$$. Bonaventura, Ad Claras Aquas, prope Florentiam, 1882-98.

De humanæ eognitionis ratione anecdota quædam Seraphici Doctoris S. Bonaventura et nonnullorum ipsius diseipulorum. Ad Claras Aquas, prope Florentiam, 1883.

Tria opuscula. Breviloquium, Itinerarium mentis in Deum et De reductione artium ad theologiam, edita studio et cura PP. Colleg. a S. l'onaventura. Quaraechi, 1890.

Boxgri. L'ultima enciclica e il pensiero del pontefice. Nuora Antologia. liv, 1885.

Bovito. Della filosofia dialettiea, suo scopo ed importanza coll'aggiunta delle regole a ben condurre le dispute filosofiche e teologiche. Siena. s. Jiernardino. 
Boxifer, E. Abclard et saint Bernard: la philosophie et l'Eglise au douzieme siecle. Paris, 1 sto.

Boswiray. Les preuves traditionnelles de lexistence de Dieu. I'ensfe contemp., 1906.

de Boxiot, S.J., J. la bete comparee a l'homme. 2. ed., Paris, Retaux, 1889.

L'ame et la physiologie. Paris, Retaux, 1889.

Borsemax, J. Anselmus et Abalardus sive initia scholasticismi. Haunie, 1840.

Iossaro, E. Alanus de Insulis. Anticlaudianus cum divina Dantiq Aligh. comardia coll. Angedavi, 1885.

Bossc, L. Sommaire de Philosophie. Louvain, Peeters, 1890.

Botratia. La composition des corps d'apres les deux principaux systemes qui divisent les fecoles catholiques. Le Puy, 1877.

Boccurrtf, H. Le rationalisme chretien a la fin du XI. siecle. Paris, 1842.

be: LA Botherit, F. A. R. L'homme, sa nature, son ame, dapres la doct rine de saint Thomas. Paris, 1890.

Bovlay, N. Principes d'anthropologie génerale. Paris, Iethielleux, 1901.

Bocqumox, Tuomas. The Iniversity of Paris. Cath. Enit. Bull, $1595-996$.

Bothgeat, J. B. Etudes sur Vineent de Beauvais on Specimen des estudes philosophiques, theologiques, scientificues au moyen age. Paris, Durand, 1 s.iti.

Hotrquarb. Doctrine de la connaissance, dapres saint Thomas d'A'quin. Angers, lsiz.

Lencyclique ".terni Patris." Paris, Berche \& Tralin, 1884.

saint Thomas dans la quastion de limmacule Conception. Cou tances, $189 \mathrm{~J}$.

Bovio, (;. Dante e la filosofia melievale. Rir. di filos. Scient., 1891.

DE: Boylesve, S.J., Marix. ('ursus philosophiar, complectens Logieam, Metaphysicam, Ethicam. Acedit compendiosa religionis demon. stratio et historia philosophiar. Parisiis, 1s5is.

Problemes contemporains. 5 vol., I'aris, listiz.

Questiones de philosophia. Sinneti closloaldi, 1863.

Problemes de philosophie morale. Ia tin derniere. Rere se. eceles., 1 sititi.

Cours de l'hilosophie. Pariq, lacottre, 18io.

ldese ot Plan do la Philosophie. laris et lyon, 1s6ti; 2. ed., Paris, Istis.

Précis de Philomephie. Paris, Iecotfre.

loggigue. 3. ed., Paris, Jeenffre, 1560; 4. ed., 187.

Principes de la morale. l'aris, lsist. 
ne Boyufsve, S.J., Maris. Plan d'études ot de lecture. 4. ed., Paris, IIaton, 1884.

Saint Thomas, ou l'Ange de l'Ecole. Paris, 1886.

Bras, C. Der hl. Bonaventura als Mystiker. Katholik, Bd. LVlll, Mainz, 1887.

Braxi, llexry A. The Spirituality and Immortality of the Human Soul. A Reply to the Materialists. New York, Cath. Public. Soc. ('o., 1885.

Braun, Fridericus. De Petri Abalardi ethica. Marburgi Cattorum, 1852.

von Brevtaxo, E. Albertus Magnus, Ordensmann, Bischof und Gelehrter. Münclien, 1881.

Brescir, J. Essai sur les "Sentences" de Pierre Lombard. Strasbourg, 1857 .

Bressones. Etude sur le traité des lois de saint Thomas d'Aquin. Rev. de l'Acad. de législation de Toulouse, 1853.

Briceño, Secuxino. Ligeros apuntos sobre la Filosofía de spencer comparada con la Filosofía Esscolástica. León, 1894.

Opusculum. De quarta figura syllogistica. Leon, 1904.

La doctrina del Angélico Doctor sobre la Inmaculada ('oncepción de la Madre de Dios. Estudio Filosófico-Teológico. León, 1904.

Respuesta a las Observaciones acerea del Opúsculo "La Doctrina del Angélico Doctor sobre la Inmaculada Concepeión de la Madre de Dios," las cuales fueron publicadas por la revista Razón y Fé, en el artículo "Santo Tomás y la Inmaculada concepción". León, 1905 .

Brix, P. M. Methodus analytico-synthetica in scientiis metaphysicis. De intellectualismo juxta mentem Syllabi vaticanique concilii adversus errores philosophicos, precipue rationalismum, positivismum et novam criticem. 3 vol., $1874-76$.

Histoire générale de la philosophie. 3 vol., 1882-86.

Brockiofs, Jos. Die Lehre des hl. Thomas von der Erkennbarkeit Gottes. Jahrb. Ph. sp. Th., 1891.

ne Brogite. Le positivisme et la science expérimentale. 2 vol., Paris, Vietorion, 1881.

La Morale sans Dieu, ses principes et ses consépuences. Paris, 1886.

La raction contre le positivisme. Paris, Plon, 1894.

Ies conditions modernes de l'accord entre la foi et la raison. Paris, Bloud, 1903.

Burines, (iabriel. La foi chretienne et la philosophie au temps de la renaissance earolingienne. Paris, 1903.

Bucuwas. Der Logoshegriff des Johannes Scotus Erigena. Leipzig, 1884.

135kofzkr. J. Maimonides im Kampf mit seinem neuesten Biographen, P. Beer. Berlin, 1844. 
Bellate (: Thesaurus philosophiar thomistica seu solecti textus philosophici ax $\mathrm{s}$. Thomar Ay. eperibus deprompti et secundum ordinem in scholis hodie usurpatum dispositi. Namnetis, 1s99; Paris, Amat, $1 !(00)$.

Berdxger, Axr. Phantasterei oder Sohwindel? Frage an den Neuscholastiker 1)r. .1. (ilossmer betreffend seine kritik der von mir vertretenen l'hilosophlia. Mïnchen, 1897.

Mrin letgtrs Wort an den Neuscholastiker Dr. M. Glossner. Miinchen, Ackermann, 1899.

Bubar. La therie des categories dans la philosophie peripatétieionne. Histoire et eritique. congress scientif. intern. des catholiques, 1597.

Bublox lekxixuez, E. Ensayos de crítica filosófica. lil alma de los brutos ante los filósofos españoles. Madrid, Hernandez, 1597.

Jaime Balmes y sus obras. Rev. Contemporanea, 1903.

Bïlow, (ikora. Des bominieus (iundissalinus fichrift von der L'nsterblichkerit der soele (Beitriige). Miinster, 1 sigt.

Btoxpexsike, O.P., H. Commentaria in 1. 1'. Summa 'Theologice $s$. Thomar Apuinatis ().P. a qu. I ad qu. xxiii. Romar, 1902.

Bergogxoxi. Le dottrine filusofiche di s. Bonaventura. Bologna, 1881.

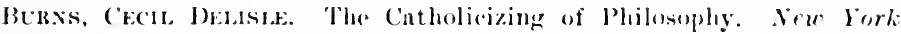
Rer., 1907 .

Berola, Paoso. Trattato della conosemza intellettuale del P. liberatore, nella parte che riguarda il Rosmini al Tribunale delldutorita. Luceal, 18.5\%.

Beroxt, (illskple. Rosmini a sian Tommuso. Torino, Ists.

Risposta al Padre comoldi di ('. di (i. in difesa delle nozioni di ontologia secondo Rosmini e sian lommaso. Torino, lsis.

La Trinita e la creazione: nuovi confronti tra losmini a $S$. Tommatso. Torino, Is79.

Berri, Axt. Le teorie politiche di San Tommano e il moderno diritto pubblico. P'arigi, Isst.

Boscomari, F. A. S. Bonaventura orelinis frotrum minorum minister gemeralis. Romil, 1sit.

('achet'x. De la philowephio de saint Thomats. Paris, lsis.

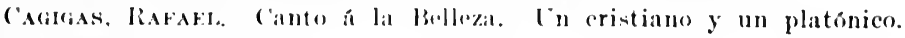
Mexiro, los!.

Obras de Rafacl ciagigas, l'bro.

Tomo 1. Pensumientos.

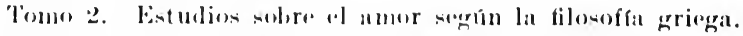

Tomo 3. linsigo sobre un mueso sistrma ideologico.

'Tomo 4. Estulios sobre la Moral. Mexico, 1890.

(Asx, JaMrs A. Right and Wrong: 'Their relation to Man's Ultimate lind: Is the Norma of Morality Absolute or Relative? Amer. r'uth. Quurt., Isst. 
Cajetanus O.P., Thomas de Vio. Commentaria in Summam Theologicam S. Thomæ Aquinatis. Rursus edita cura H. Prosperi. Lyræ, $1891 \mathrm{ff}$.

Cambier, O. J. Elementa philosophiæ scholasticæ. 2. ed., Tournai, 1895. Canalejas, F. DE P. Las doctrinas del doctor iluminado Raimundo Lulio, 1270-1315.

Canelua, G. Del problema degli universali e del nominalismo nella prima fase del loro svolgimento storico. Scuola Cattolica, $1906-7$.

da Capannori, Bernardo. Sull'insegnamento rosminiano. Lueea, 1854.

Capello, F. Cenni storici e critici sullorigine e natura della filosofia scolastica. Torino, 1879.

Principii di filosofia secondo San Tommaso. Kassegna naz., 1890.

Cappozza, F. Sulla Filosofia dei Padri e Dottori della Chiesa e in ispecialta di San Tommaso in opposizione alla Filosofia moderna. 1868.

Cappentazzi, Andrea. Gli elementi del pensiero. Studio di psicologia e ideologia secondo la dottrina di S. Tommaso d'Aquino. Crema, 1888.

Le moderne liberta esaminate secondo i principii della filosofia scolastica. Crema, Cazzamali, 1890.

L'Ultima Critica di Ausonio Franchi compendiata. Parte 2. Del sentimento. Crema, Rolleri, 1891.

La dottrina di S. Tommaso sulla conoscenza che Dio ha delle cose. Parma, 1893.

Il principio etico e il principio giuridico considerati nel concetto scienziale e nella manifestazione storica. Lodi, 1894.

San Tommaso e la schiavitu. Crema, 1900.

La persona nella dottrina di San Tommaso d'Aquino e l'odierno movimento intellettuale. Siena, s. Bernardino, 1900.

Filosofia sociale. Quale sede occupa la sociologia nella gerarchia scientifica. Siena, s. Bernardino, 1902.

La dottrina di San Tommaso nella soeiologia moderna. Parte 1. Sociologia economica. Bitonto, tip. Veseovile, 1902.

Le questioni moderne. Siena, s. Bernardino.

Sociologia civile. Siena, s. Bernardino.

La superiorita e l'immanenza del Sacerdozio eattolico. Siena, 8. Bernardino.

Qui est: Studio comparativo tra la 2. questione della Somma Teologrica di San Tommaso e le conclusioni di sisteni filosofiei. Crema, 1903.

Cappelli. Il concetto della vita scientifieamente e moralmente considerata. Siena, s. Bernardino.

Capreolys. Defensiones Theologiæ Divi Thomæ. Tours, 1900-2.

Carbonel. Ilistoire de la Philosophie. Paris, 1883. 


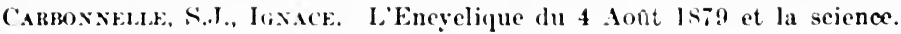
Bruxelles, 18i!!.

Les confins de la seience et de la philosophie. 2. ed., Paris, Palme, 1881.

('arle, P. J. Histoire de la vie et des eerits de saint Thomas d'Aquin. Paric, 1s.ti.

Carryle, A. I. Political theories of Thomas Aquinas. Scottish Rer., 1896.

Carbyls, R. W. Theories of Thomas Aquinas on Chureh and state. Econ. Rer., Is9t.

('aro, E. X. Ia philosophie de saint Thomas d'Aquin. Rev. Contemp., 1558.

(Ano, Matkl Axtoxio. Estudio sobre el Ćtilitarismo. Bogotá, 1569.

('Akplo, Jax. Discurso pronunciado por el Señor Vice-Rector y Catedrático del mismo ('olegio (Seminario de león), Pbro. D). J. C'arpio. León, 18699 ; 2. ed., 1870.

Canka de: Valx. Le syllogisme. Ann. de Philos. chr., lsis.

Avicenne, Paris, Alean, 1900.

Cabrasquilla, Rafake María. Sobre el estudio do la filonoffa. Repert. Colomb., Agto de 1881.

Ensayo sobre la doctrina liberal. 2. ed., Madrid, 1899.

Lecturas sobre al arte de educar. Rer. Col. del Rosario, 1906.

Carbasquila, Ricario. Sofismas anticatólicos vistos con microseopio. Bogotá, lib. Americana, 1881.

(arkière, Moritz. Abilard und lfeloise. Giessen, 1844; 2. ed., 1853.

Cartasegis, Domexico. Panegirico di San Tommaso d'Aquino. Genova, lings.

nk: Casamajor, L. Heterogenie, transformisme et darwinisme. Probleme d. l'espece. Bar-le-1)ue, 1901.

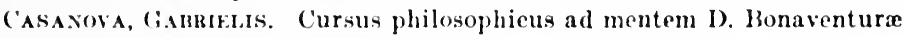
et Scoti. Matriti, 1s!4.

Casaba, Ska. I Rominiani e l'ontologismo del I'. Cornoldi. Milano, lisis.

'Astrixis, S.I., A. ('ours de Philosophie. Namur, 1887-89; n. ed., Bruxilles, 1!901.

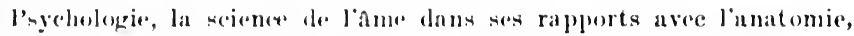
la phyniolegie et l'hypmotinme. Nammr, Delvaux, 1890.

Le Socialisme at le droit de propriete. Bruxelles, 1896.

Institutiones philonophia moralis et socialis. Bruxelles, 1900.

Intitutiones philosophiar meralen et socialis. Editio minor. Bruxelles, lonot.

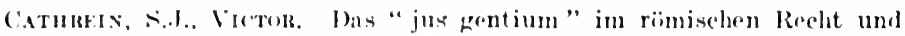
beim hl. Thomat voll Aguin. Philos. Jahrb., Isse.

Moralphilosephie. Eine wimenschaftliche Darlegung der sittlichen, ainkeh, der rechtlichen Grdmung. Freiburg-i.ls., Herder, 1891; 3. ed., 1 s!99. 
Catureix, S.J., Victor. Der Socialismus. Eine Untersuchung seiner Grundlagen und seiner Iurchfuirbarkeit. Freiburg-i-13., 7. ed., 1898 ; Span. by E. Vogel, Madrid, 1891; by Sabino Aznarez, S.J., Barcelona, 1907; Engl. by James Conway, New York, 1892; Ital. by (․ C'eceoni, Torino, 1898.

Das Privatgrundeigenthum und seine Gegner. Freiburg-i-B., 1892. Philosophia moralis in usum scholarum. Freiburg-i-B., Herder, 1893. ed. 3., 1900.

Worin besteht das Wesen des sittlich Guten und des sittlich Bösen? Philos. Jahrb., 1896.

Der Begriff des sittlich Guten. Philos. Jahrb., 1899.

Recht, Naturrecht und positives Reeht. Eine kritische Untersuchung der Grundbegrifle der Rechtsordnung. Freiburg, Herder, 1901 .

Die Framenfrage. Freiburg, Herder, 1901.

Die katholische Moral in ihren Voraussetzungen und ihren Grundlinien. Freiburg, Herder, 1907.

Causette. Saint Bernard and his Work. Transl. from the French by A. Burder. London, 1874.

Cavanagil, O.P., Prus. The life of St. Thomas Aquinas, the Angelic Doctor. London, Burns \& Oates.

de Ceballos, Fersaxdo. Insanias ó demencias de los filósofos eonfundidas por la sabiduría de la Cruz. Obra inédita publicada por 1). León ('arbonero y Sol. Madrid, Perez Dulrull, 1878.

Cerllier, Il. Le problème spiritualiste; l'existence de l'âme. Paris. Beauchesne, 1893.

('enutri, Fraxc. Déprincipii pedagogico-sociali di San Tommaso. Torino, 1893.

Criabix, S.J., P. Les vrais principes du droit naturel, politique et social. Paris, Berche \& Tralin, 1901.

Cinaries, Emilk. Roger Bacon: sa vie, ses ouvrages, ses doetrines, d'après des textes inedits. Paris, 1861.

Cilaria, A. Saint Anselme. Caen, 1854.

('maroussir, A. Le Problème metaphysique du Mixte. Rer. de Philos., 1903.

(natard, Fraxcis Silas. The Brute-Soul. Cath. World, 1893.

C'inevaler, C. U. .J. Saint Thomas d'Aquin: bio-bibliographie. Montebourg, 1883.

Catalogue eritique des aurres de saint Thomas d'Aquin. Rome, 1887.

Chinsa, L. La Biomecanica, il Neovitalismo e il Vitalismo tradizionale. lioma, 1900 .

La base del realismo e la critica neo-kantiana. Roma, 1901.

Chocarie. Saint Thomas d'Aquin et l'encyclique de Léon XIII. Paris, 1884. 
('nolder, J. A. De syntheri philosophica 1). Themes Aquinatis. Rev. sci eceles., $1 \times 97$.

De la netion clordre. parallelisme des trois ordres de l'etre, du vrai, du bien. l'aris. Lethielleux, 1 s.99.

la morale strüeiene en face de la morale cheretienne. Paris, Lethiel. loux, lsags.

La pephologie des alus. Paris. Lethiolleux. 1901.

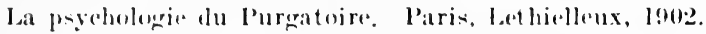

La peycholegire du christ. l'aris, Lethielleux, 1903.

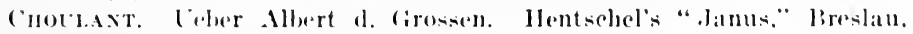
listiti.

('nketex, A. Etudes sur le mouvement nerothomiste. Rer. int. de therel., Berne. 1899.

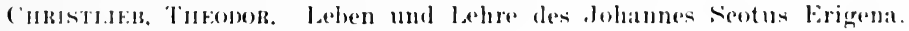
liothal, listot).

Cursostom, Bkother. Elementary ('ourse of ('hristian Philosoplyy. bated on the principles of the best seholastic authors. Adapted

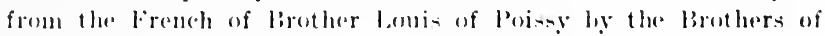

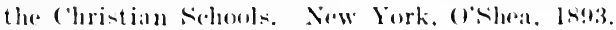

The theistic Argument of st. Themas. Philes. Rer., I89.4.

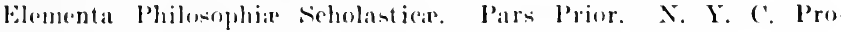
tectory, 1 sist.

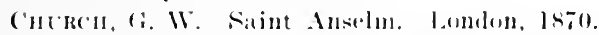

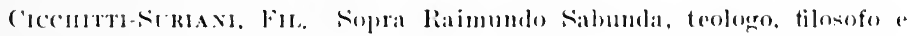
medien del sereolo XV. Aquila, lssis.

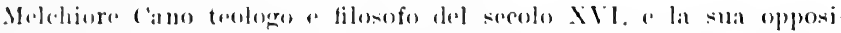
zione all Arieteteliome della seolastima. Aquila, tip. Aternina. $1 \times 91$

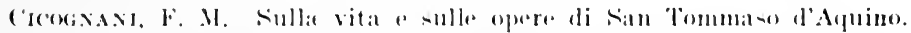
Venezia, 1874 .

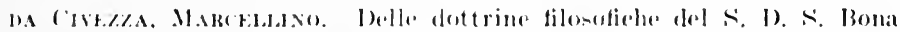
ventura. lienova, lisit.

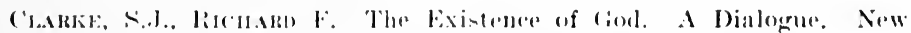
Sork, Benziger, sisti.

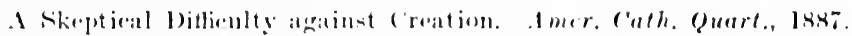

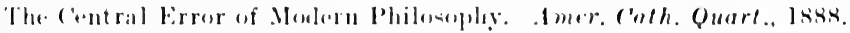

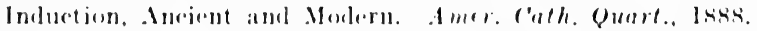

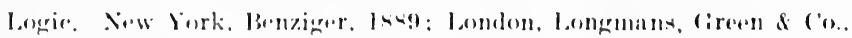
19101 .

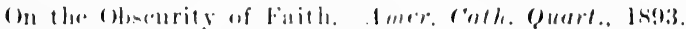

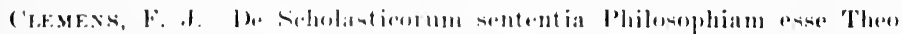
longia nneillam. (ommentatio. Monasterii Guestphalorum. 185i.

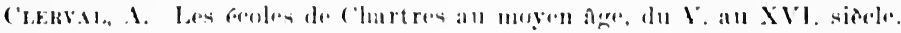
l'aric. In!s. 
Coconnier, O.P., Thom. L'âme humaine, son existence et sa nature. Paris, 1890.

Le vrai thomiste. Rev. Thom., 1893.

Coffey, P. A New Book on Scholastic Philosophy. Irish Eccles. Rec., 1907.

Colvenerius. Die Anfänge wissenschaftlicher Naturgeschichte und naturhistorischer Abbildung im christlichen Abendlande. Leipzig, 1856.

Combes, J. L. Emile. La Psychologie de saint Thomas d'Aquin. 1860.

Comelifas y Cluft, Antonio. Demonstración de la armonía entre la religión católica y la ciencia. Barcelona, 1880 .

Introducción a la filosofía, ó sea doctrina sobre la dirección al ideal de la ciencia. Barcelona, 1883.

Commer, Ernst. Die philosophische Wissenschaft. Berlin, 1882. System der Philosophie. Paderborn, 1883-86.

Logik (als Lehrbuch dargestellt). Paderborn, 1897.

Die immerwährende Philosophie. Wien, 1899.

Compagsion, J. Critique thomiste du thomisme. Pas-de-Calais, 1907.

ne Coxcino, J. Catholicity and Pantheism. All Truth or no Truth. New York, Sadlier, 1874; n. ed., 1881.

The Elements of Intellectual Philosophy. New York, Sadlier, 1878.

The Doctrine of St. Thomas on the Right of Property and its Use. New York, Pustet, 1887.

Scientitic and Metaphysical Cosmology. Amer. Eceles. Ret., 1892.

Contestris, G. Le matérialisne et la nature de l'homme. Paris, Bloud, 1900.

La Providence. Conservation des êtres crếs. Gouverument du monde. Répartition des biens et des maux. Paris, Bloud, 1901.

Conti, Augusto. Evidenza, Amore e Fede, o i eriterii della tilosofia. Firenze, 1858.

Storia della Filosofia. Firenze, 1864; 3. ed., 1882; French by leon Collas, 1881.

La filosofia di Dante. Firenze, 1865.

11 Vero nell'Ordine. Firenze, 1876.

('oxtzen. Zur Wurdigung des Mittelalters mit besonderer Beziehung auf die Staatslehre des hl. Thomas von Aquin. Cassel, 1870.

Conway, S.J., James. The True Idea of the Beautiful. Amer. Cath. Quart., 1885.

The Fundamental Principles of Christian Ethies. Chicago, McBride, 1896.

Coppexs, S.J., Charles. A Brief Text-book of Logic and Mental Philosophy. New York, Cath. Pub. Soe., 1892.

A Brief 'lext-book of Moral Philosophy. New York, Cath. Bk Co., 1896.

Moral Principles and Medieal Practice. New York, Benziger, 1897. 
Conconax, Jants A. The Immortality of the soul. Amer. C'ath. Quart, $187 \%$

The Recent Encyelical Letter of Pope leo Xlll. Amer. Cath. Quart.. Isis.

de Cónons, ls. Noticia histórico-literaria del boctor l). I. laalmes, Pl,ro. México, Isjo.

('orxeliz, Art. Compendium philosophia generulis seu fundamentalis. ed. 2.. 'Turino, 1896.

Corsoldi, S.J., (ilovisw Maria. I sistemi meceanico e dinamico cirea la contituzione della sostanza corporea rispetto alle scienze fische. Verona, 1 s64.

Thesaurus philosophorum, seu Distinetiones et axiomata a (ieorgio Reel, S. J. proposita a .. M. Cornolan ejusdem Societatis recognita et aucta. Brixinae, lsil; ed. n., Paris, lethelleux, 1875.

Die antikatholische Philosophie und die gegenwirtige Cebel der Gesellschaft. Aus dem Italien. Irixen, Weger, lsil.

Lezicni di filosofia, ordinate allo studio delle altre scienze. Firenze, 1872 ; 2. ed., Ferrara, 1875 ; Engl., London, 1876; Span., Barcelona, 1878; French par un Professeur du (irand-seminaire, Paris, Lethielleux, 1878; 2. ed., 1888.

Viribus unitis. Prolusione al periodico "La scienza italiana." Bologna, 1576 .

La Sintesi chimica secondo i principii filosofiei di $\rightarrow$. Tommaso d'Aquino. Bologna, 1876.

Francisci Suarezii doctoris aximii: De corporum natura Tractatus. Bononia, Mareggiani, $187 \pi$.

Prolegomeni sopra la tilosefia italiana o Trattato della esintenza di Dio. Bologna, Mareggiani, 187i.

Della pluralita delle forme secondo i principii filosofici di San 'Tommaso d'Aquino. Bologna, $18 i \pi$.

La conciliazione della fede cattolica con la vera scienza; ossia Accalemia filosofico-medica di $\rightarrow$. Tommaso d'Aquino. Bologna. $1877 ; 2$ ed. con appendice, 18is; Span. ly J. F. Montana; Madrid, Isis.

Institutiones philosophiar speculative ad mentem s. Thoma Aquinatis, auctore J. M. ('ornoldi 5 . .J. in latinum versa al Excmo. et Revmo. Dominico Agostini Venetiarum Patriatrela et ab nuctore recognitia et auctip. Bononiar. lisis.

Nozione elementare dellontologiomo. Belogna, lozs.

Il Panteinmo ontolegien e lo nezioni di Cntologin del M. R. (i. Buroni. Bologna, Mareggiani, lsis.

La storia del conflitto tra la religione e la seienzal di (i. Draper, prof. nell'lniv. di Nuova York. Ed. 2., Bologna, Maregginni, 1hi9; Silan., Madrid, 1879.

La riforma della filesofia promessa dall'knciclien Aiterni latris di S. S. I.eon Papa Xlll. Belogna. Mareggiani, 1879. 
Cornoldi, S.J., Giovaxis Maria. Il sette Marzo 1880, ossia i filosofi ai piedi di Leone XIII, ristoratore della filosofia. Bologna, 1880.

La filosofia scolastica speculativa di San Tommaso d'Aquino. Bologna, 1881.

Dei principii fisico-razionali secondo S. Tommaso d'Aquino. Commentario dell'Opusculo "De principiis naturæ." Bologna, 1881.

Il Rosminianismo sintesi dell'Ontologismo e del Panteismo. Roma, Befani, 1881-83.

Antitesi della dottrina di S. Tommaso con quella del Rosmini. Prato, Giachetti, 1882.

Dell'unione dell'anima umana col corpo; Roma, Befani, 1882.

Del senso comune e del senso fondamentale del Rosmini. Roma, Befani, 1882.

La lotta del pensicro. Roma, Befani, 1882.

L'intelletto agente. Roma, Befani, 1883.

Della liberta umana. Dissertazione. Roma, Befani, 1883.

La cognizione umana dei futuri. Roma, Befani, 1885.

La filosofia di s. Tommaso e l'epoca presente. Prato, Giachetti, 1886.

Esord1o del concetto di Dio. Roma, 1887.

La Creazione. Roma, Befani, 1888.

La Dirina Commedia di Dante Alighieri, col commento di G. M. Cornoldi. Rioma, Befani, 1888.

La filosofia scolastica di San Tonmaso e di Dante. Bologna, 1889.

Esame critico del traducianismo. Roma, Befani, 1889.

La visione dell'essenza divina. Roma, Befani, 1889.

Quale secondo S. Tommaso sia la concordia della mozione divina colla liberta umana. 3. ed., Roma, Befani, 1890.

Sistema fisico di San 'Tommaso. Roma, 1891; Engl. by E. H. Dering, London, 1893.

Partenio. La creazione e la inmacolata. Conversazioni scolastiche. Roma, Befani, 1891.

del Conoxa, P. A. I quattro eardini della felicita secondo San Tommaso d'Aquino. lirenze, $187 t$.

Correxs, P. Die dem Boethius failschlich zugesehriebene Abhandlung des Dominicus (iundisalvi de unitate (Beitrige). Mïnster, 1891.

Corti, Setrimio. L'assurdita della metodica scolastica nell'insegnamento medio. Siena, $190 \pi$.

Costaxzi. Un recente contributo di Ruggero Bacone. Ret. int. di sci. sociali, 1900 .

Costa-Rosettr, S.J., Jurles. Philosophia moralis s. institutiones ethica et juris natura secundum principia philosophia scholastica, prasertim S. Thome, Suarez et De Iugo methodo scholastica elucubrata. Oeniponte, 1883; 2. ed., 1886. 


\section{7}

Costa-Rosettr, S.J., Jutus. Allgemeine (irundlagen der National Gekonomie. laritrige zu dinem Sistem der National-Oekonomie im Geiste der Seholantik. Freiburg. Herder, lsist.

Die Staatslehre der christlichen Philosophie. Fulda, Actiendruck. erei, 1s90.

IE: coster, I. Ie prohleme de la tinalité. Lomvin, Issi.

Coldanac. S.J., l'. La liberté et la conservation de l'énergie. Parix. Ideotline, 1s!3

Dectrina de ideis, divi Thoma divique Bonaventura conciliatrix. Paris, $1 \mathrm{~s} 9 \%$.

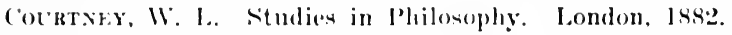

Roger Bacon. Fortn. Rer., lii, 254.

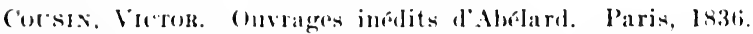

Fragments de philosephie du mogen age. Paris. 1840; 5. ed., 1865.

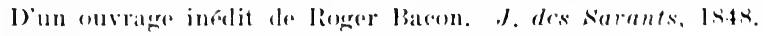

Framents philosophigues. Paris, 18.50.

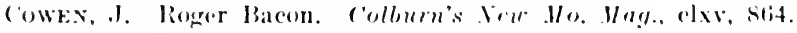

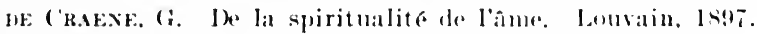

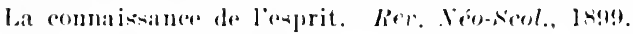

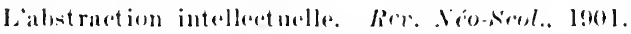

('ranty, E. la politipue de saint Thomas d'Apuin. Lourain, lseg.

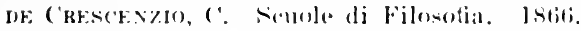

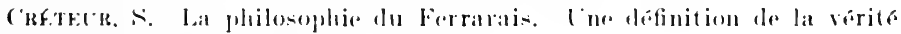
Rer. an!ust., 1907 .

('realoser. S.l., J. Des Aristoteles lahre iiber die Willensfreiheit. Philes. Jahrb., J907.

Croctraro, P. R. Ia tilosofia di Augusto conti a lo stato presente della

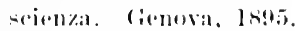

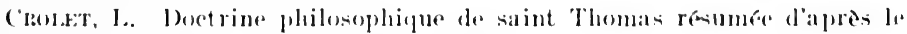
1)r. Stowekl. raris, Roger, 1890.

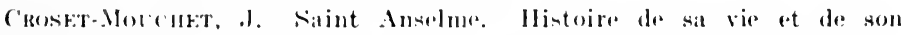
tempes. Paris. Isis?.

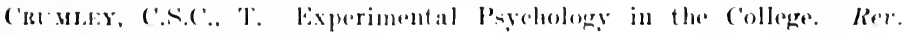
r'ath. P'otag.. 1903.

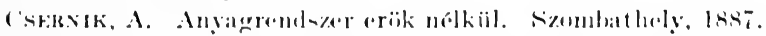

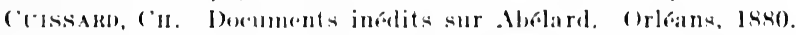

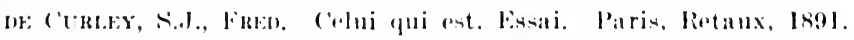

(anreus Philosophicus. In usum seholarmm. Auetoribus pluribus phi

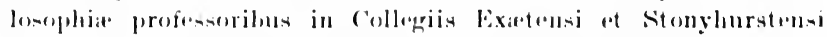
S. J.; Freilure, Herder, 1s!3-95. (c'f. Beedder, cathrein, Frick, Hatan.)

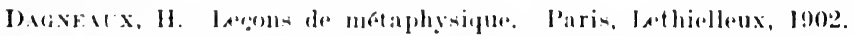

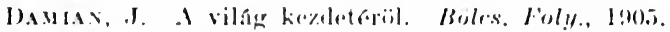

Daxtik. I'n manuserit autographe de saint Thomns d'Apuin. Rer. contomp., 1hist. 


\section{8}

DarLey. L'accord de la liberté avec la conservation de l'énergie et saint Thomas. Rev. thom., 1900.

Daurelia y Rull, J. Instituciones de Metafísica. Valladolid, Rodriguez, 1891.

Daux. Un scholastique du XII. siècle trop oublié: Honoré d'Autun. Rev. sci. ecclés., 1907.

David. La philosophie de saint Thomas d'Aquin. Correspondant, 1859.

Davidson, Th. The Philosophy of Thomas Aquinas. J. Specul. Phil., 1876.

Revival of Thomas Aquinas. Fortn. Rev., xxxviii, 16.

Dedericir, A. Beitrïge zur römiseh-deutschen Geschichte am Niederrhein. Anhang: das Leben des h. Willibrodus nach Alcuin. Emmerich, 1850.

Definitiones ex Philosophia a S. Tongiorgi S. J. et in Collegio Romano Professore elucubrata, quoad majorem partem excerptæ. Editio nova. Zaeatecarum, 1880.

Defourny, 11. La sociologie positiviste. Auguste Comte. Louvain, 1902.

Delacroix, H. Essai sur le mysticisme spéculatif en Allemagne an XIV. siècle. Paris, Alcan, 1900.

La philosophie médiévale latine jusqu'au XIV. siecle. Rev. de synthèse histor., 1902.

Delaunay, D. Sancti Thomæ de origine idearum doctrina. Paris, 1876.

Delécluze, E. Vie de Raymond Lulle. Rev. des Deux-Mondes, 1840.

Gregoire VII, saint Francois d'Assise et saint Thomas d'Aquin. Paris, 1844.

Delexgre, M. J. Saint Thomas d'Aquin. Un épisode de sal carrière universitaire a Paris. Paris, Lethielleux, 1904.

Delitzscir, J. Die Gotteslehre des Thomas von Aquino kritisch dargestellt. Leipzig, 1870.

Delmas, S.J., Carouts. Ontologia. Metaphysica Generalis. Paris, Retaux, 1896.

Dembó, G. A jog fogalma és eredete. Bölcs. Foly., 1905.

Dexifle, O.P., Heisrich. Abaelard's Sentenzen und dic Bearbeitung seiner Theologia. Arch. $f$. Litteratur und Kirchengeschichte des Mittelalters, 1885.

Iie Entstehung der Unversitäten des Mittelalters bis 1400. Berlin, 1885.

Das geistliche Leben. Blumenlese aus den deutschen Mystikern und Gottesfreuden des 14. Jahrhunderts. 5. ed., Graz, Moser, 1904; French, Troyes, 1897 .

Denifle, O.P., H. axd A. Chatelaix. Chartularim Universitatis Parisiensis. Paris, 1889-91.

Depiofik, Simox. La theorie thomiste de la proprieté; Louvain, 1895.

saint Thomas at la question juive. Lowvain, 1897. 
Dectsci, S. M. Die Sunode von Sena. 114l. Berlin, lseo.

leter Abaclard, ein kritischer Theologen des zwïlften Jahrhundert Leipzig. 1883.

DEx, O.F.M., (i. Ethica generalis ad mentem venerabilis J. Scoti, Doc toris subtilis. Friburgi. Herder, 1907.

A Dialogue on the Late Encyclical on Liberty and the Light of Natural Reason. By a Thomist. London, Burns \& Oates, 1888.

Dinlo. Die moderne Moral und ihre Grundprincipien (Strassburger theolog. Studier, 11, 3). Freiburg, 1896.

Didiot, Jir.s. Is Docteur Angelique, saint Thomas d'Aquin. Lille, 180.4.

Contribution philosophique a l'étude des sciences. Lille, 1902.

A Discusion with an Infidel. Jeing a review of I)r. L. Jiichner's "Furce and Matter" hy a l'riest of the Society of Jesus. Ionden, Art and Book Co., 1891.

Ioctor. Max. Die Philosophie des Jozef (Ibn) Zaddik nach ihren Quellen, insbesondere nach ihren Beziehungen zu den lauteren Briidern und zu (ial)irol untersucht (Beitrigge). Miinster, 1995.

Domaxski, B. Die Psychologie des Nemesius (Beitriige). Minster, 1900.

Domaszewicz, J. Swint i czlowick, stulyum dogmatyczne na potstawir sw. Tomasza. Warszalwa, 1899.

Domet df: Vorges, E. La Metaphysique en présence des sciences. Patris, 18.5.

Essai de metaphysique positive. Paris, 1883.

la constitution de l'etre suivant la doctrine peripatéticienne. Paris, 18 sig.

Bibliographie de la philosoplie thomiste de 1877 a 1887 . Ann. de Philos. chret., Is\&s.

Determination des cauces crefes. Alln. de Philos. chr., 1858.

(ause efliciente et calse finale. Paris, lsao.

La Pereeption et la Pugehologie thomiste. Paris, Roger \& Chernoviz, 1592.

Les rescorte de la volonte ot le libre arbitre. Jruxelles, 189.5.

lobjectivite de la connaissane intellectuelle d'apres saint Thomay.

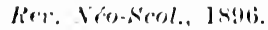

Les certitudes de l'expéricnee. l'aris, linger \& ('hernoviz, ls9s.

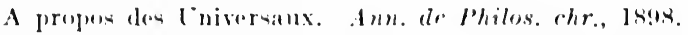

Ia lhilesephie theminte pendant les annese loss-lsas. Paris, Soc. biblicgraphique, 1899.

Largument de saint Anselme. Rer. de Philos., 1901.

Saint Ansulme. l'aris, Alean, 1901.

En fuelle langue doit etre enseignes la philosophie seolastique. Rer. resesteol. 1900:?. 
Domet ne: Vorges, E. Considerations sur la "Critique de la Raison Pure." Arras, sueur-Charruey, 1904.

Abrégé de métaphysique, étude historique et critique des doctrines de la métaphysique scolastique, d'après les renseignements des principaux docteurs. 2 vol., Paris, Lethielleux, 1906.

La Philosophie médiévale d’après M. Pieavet. Rev. de Philos., 1906. Donadu y Puignau. Ampliación de Psicología y nociones de Ontología, Cosmología y Teodicea. Barcelona, 1886.

Curso de Metafísica. Barcelona, 1887.

Doxat, S.J., Jos. Zur Frage iiber den Begriff des Schönen. Philos. Jahrb., 1900-1.

Donati, Bernardico. Intorno al panteismo, al materialismo ed al positivismo contemporanei, scritti varii. Siena, s. Bernardino.

Il concetto materialistico della vita, per il dottore G. Romiti, Prof. di anatonia umana nella $R$. Universita di Siena, esaminato dal Can. Dott. B. Donati. Siena, s. Bernardino.

Doovan, S.J., Janes A. Some Elementary Studies in Psychology. Cath. Read. Circle Rev., 1894-95.

Dörıolt, B. Erkläirung einer schwierigen Stelle der Qu. de Veritate des hl. Thomas. Jahrb. Ph. sp. Th., 1895.

Zur mittelalterlichen Controverse uher die unbefleckte Empfangniss. Jahrb. Ph. sp. Th., 1896.

Der hl. Bonaventura und die thomistisch-molinistische Controverse. Jahrb. Ph. sp. Th., 1897.

Dovais, G. Essai sur l'organisation des études dans l'Ordre des Frères Prêcheurs au XIII. et au XIV. siècle. Paris, 1884.

Dounlier, I. Roger Bacon: eine culturgeschichtliche Studie. Wien, 1886.

Dovgnerty, J. T. Albertus Magnus. Cath. World, xxxvii.

DRÄSEKE, JoH. Johannes Scotus Erigena und dessen Gewïlrsmänner in seinem Werke De Divisione Naturæ libri V. Leipzig, 1902.

Drasseil, S.J.. L. Der belebte und der unbelebte Stoff. Freiburg-i-B., 1883.

Driscoln, Joux T. Christian Philosophy: A Treatise on the Human Sonl. New York, Benziger, 1898; 3. ed., 1900.

('hristian Philosophy: God. New York, 1900.

Philosephy and Science at the Dawn of the Twentieth Century. North Amer. Rev., 1903.

The Notion of Morality. N. Y. Rev., 1906.

Dubray, Charles. The Theory of Psychical Dispositions. The Macmillan Co., 190.5 .

The New Psychology. Cath. Univ. Bull., 1907.

Deffy, Fraxcis. The current Science-Philosophy. New York Rev., 1907. 


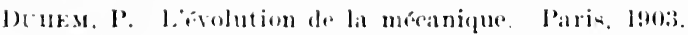

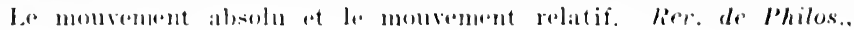
1907.

D) krs, Leopoto. Silomo ben liehirol au Malagal und die ethischen Werke desselben. Hannover, Initio.

Philosophi-ches atu dem zehnten lahrhumbert. Fin Beitrag zur literaturgenehichte dor Mohameder und Juden. Nakel, lsits.

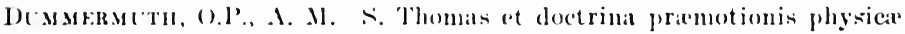
seu responsio ad R. P'. Sohmemann. P'aris. Lethielleux, lssti.

Defensio doetrina saneti Thoma dy. de pramotione physilea seu responsio ad li. R'. V. Frins S. J. Louvain, ls9ti.

D) Makr, Eksist. Anselm der Peripatetiker, nehst anderen beitriigen zur literaturgeschichte Italiens im Xl. Jahrh. Halle, lsiz.

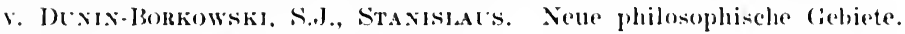
stimm. aus .Jaria-Laach, 19013.

Deparay, B. Pierre le Vénerable, albé de Cluny. Chalons-s-Saonte, lstiz.

D) Prirat, A. Manuductio ad Sicholastienm, maxime vero thomistieam philosophiam. Parisiis, Lecoffre, 1ss4; ed. 3., 1 s!og.

Depost. Theres metaphysigues. Louvain, 1sits.

Philosophie do saint Augustin. Louvain. Isisl.

Spiritualite de lame. Igen, Isss.

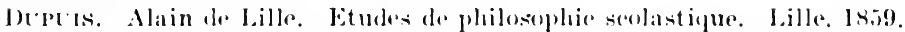
berry, A. Aleuin et leecole de saint Martin de Tours. Paris, lazti.

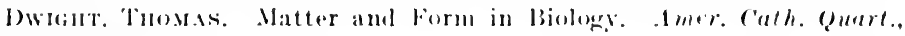
$15: 2$.

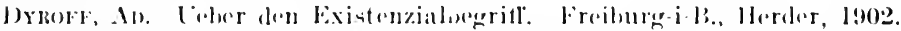

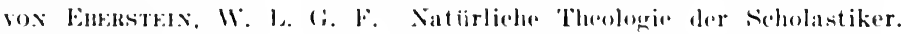
lopiprig, Inols.

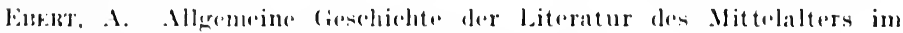

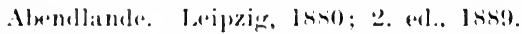

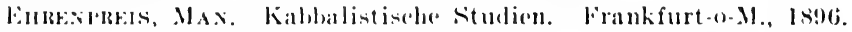

Eumarb. Jer katholicismus und das zwanzigste Jahrhundert im l.jehte der kirehliehen lintwieklung der Nenzeit. Stuttgart, 1902.

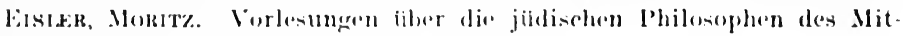
tolalters. 2. Ahtheilung; Wien, 1sio.

Vorlesungen ibler die jibliwhen Philuenphen des Mittolalters. I. Altheilung: Wi(nn. Ixiti.

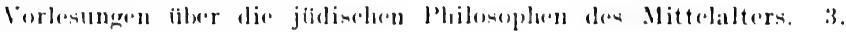
Altheilung: Wien, Istis.

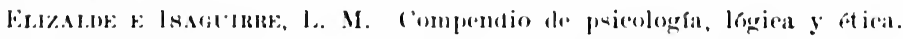
Madrid, Issti; 3. enl., 1902.2.

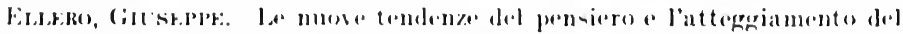
cattolicismo al principio del necolo XX. Siena, s. Bernardino.

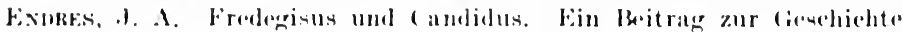

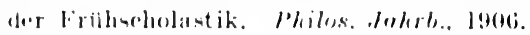


Endres, J. A. Zum dritten Band der Epistolæ Karolini. Archiv d. Gessellschaft $f$. aeltere deutsche Ge8chichte, 1906.

ENDriss, Gustav. Albertus Magnus als Interpret der aristotelischen Metaphysik. München, 1886.

Engelkemper, W. Die Lehre Saadia Gaon's ueber die "Aufhebung des Gesetzes." Ein Capitel aus der arabisch-juidischen Scholastik. Philos. Jahrb., 1900.

Exgexheimer, Jos. Die Religionsphilosophie des R. Abraham benDavid-Ia-Levi. Augsburg, 1850.

Englert, W. Philosophia Logica. Prima Pars Summæ Philosophiæe et operibus Angel. Doctoris S. Thomæ Aq. juxta cursum philos. Cosmi Alamanni instituta. Paderborn, Schöning, 1901.

Ercole, P. D. Il teismo filosofico cristiano, considerato con ispeciale riguardo a San Tommaso. Torino, 1884.

Erigena, Johannes Scotes. De Divisione Naturæ libri quinque, ed. C. B. Schlüter. Monasterii Guestphalorum, 1838.

De Joanne Scoto Erigena commendatio. Bonnæ, 1845.

Ermoxi, V. Existentia Dei et philosophus christianus. Dit. Thom., 1890-91.

De principiis rationis speculativæ. Div. Thom., 1892.

Le Thomisme et les résultats de la psychologie expérimentale. Rev. Néo-Scol., 1898.

De natura causæ et ejusdem notionis origine. Div. Thom., 1900.

De natura substantiæ. Div. Thom., 1901.

Necessité de la métaphysique. Rev. Néo-ścol., 1906.

van Es, P. M. En woord van Pius IX over den hl. Thomas van Aquino uiteengezet. Utrecht, 1872 .

España Lledo, Jos. Filosofía: Lógica. Madrid, Hernando, 1900.

Filosofia: Psicologia. Madrid, Hernando, 1900.

Filosofía. (Ampliación al estudio de la lígica fundamental.) Metodología aristotélico-cristiana con la de los principales sistemas filosíficos. Madrid, Hernando, 1901.

Filosofía. Nociones de Sociología. Madrid, Hernando, 1901.

Espenberger, Joir. Nep. Die Philosophie des Petrus Lombardus und ihre Stellung im zwölften Jahrhundert (Beiträge). Münster, 1901 .

Esırí, J. La metafísica y el empirismo. Razón y l'é., 1902-3.

Esser, O.P., Tromas. Rosminian Ontologism. Lublin Rev., 1889.

Die Lehre des hl. Thomas bezïglich der Möglichkeit einer ewigen Weltschöpfung. Jahrb. Ph. sp. Th., 1890-92.

Die Lehre des hl. Thomas von Aquino über die Möglichkeit einer anfangslosen Schöpfung. Münster, Aschendorff, 1895.

Euckex, Rudolf. Die Philosophie des Thomas von Aquino und die Cultur der Neuzeit. Halle, 1886. 
Euckex, Rumolf. Neuthomismus und die neuere Wissenschaft. Philos. Monatshefte, 1888 .

Frohschammer's Thomas von Aquino. Philos. Momatshefte, 1890.

Thomas von Aquino und Kant. Ein Kampf zweier Welten. hantstudien, 1901; Berlin, Reuther \& Reichard, 1901.

Das wissenschaftliche Zentrum des heutigen Thomismus. Miinchen. 1904.

Evavgensta, P. Conspectus principiorum fundamentalimm philosophie speculative Seraphici Doctoris S. Bonaventure. Iir. Thom., 1890.

Ezechifi. a S. ('. Jese O. C. D). Annotationes in Summam D). Thomar. De Deo C'reante et Gubernante. Rome, Pustet, l!03.

Farges. Alnert. Theorie fondamentale de lacte et de la puisianee, du moteur et du mobile. Paris, 1886: 5. ed., 1900: Ital. ly ('. Boni, Siena, s. Bernardino, 1900.

Lunite de principe pour les trois vies. Ann. de Philos. chr., 1888. Matiere et Forme en présence des scienees modernes. Paris, 1892:

4. ed., 189.5; Ital. by C. Boni, Siena, s. Bernardino.

La vie et l'evolution des especes. Paris, 1892; 5. ed.. 1900; Ital. by Elena, Torino, 1896.

Le cervalu, liame et les facultes. Paris, 1892; 6. ed., 1900; Ital. by Silvio Monaci.

L'objectivite de la perception des sens externes et les theories modernes. Paris. 1885; 4. ed., 1900; Ital. by R. Spada, Nienn, 8. Bernardino.

Lidere de continu dans l'espace et dans le temps, refutution du kantisme, du dynamisme et du réalisme. Paris, 1892: 4. ed., 1900.

lides de Dieu d'apres la raison et la science. Paris, 15!) 4; 4. ed., 1900.

La liberte et le devoir, fondemente de la morale et eritique des sys. temes de morale eontemporains. Paris. Bepele \& Tralin, 1902.

La crise de la certitude. Etude des bases de la eonnatissance et de la eroyance avee la critique du neo-kantisme. du pragmatisme. du newmanisme. Paris. Berche \& Tralin, 1907.

Le donte methodique peit il etre univerel? Rer. de l'hilos. 1907.

Le eritere de l'evidence. Rre. Thom., 1907.

Comment il faut refuter kant. Rer. Thom., 1907.

Farges, A., and Barmantrte. Philosophia seholastien ad mentem S. Thoma Apuinutis exposita ef recentiorihus scientiarum inventis nptuta. Paris. Berche \& Tralin, 1s!3:3.

Fabgites. De Dere ('no. Dir. Thom., 1902.

Farkik. F. W. Roger Bateon. Sundey Hag., xix, gis.

Thoman Aquinas. Sunda!y Mng., xix, 6334.

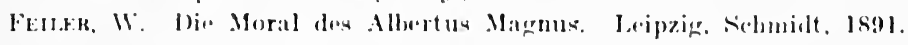


Fenculis, B. Ueber den realen Unterschied zwisehen Wesenheit und Dasein in den Geschöpfen nach St. Thomas. Zcitsch. f. kath. Theol., 1892.

Felderer, Gundisalv. Die Lehre des hl. Thomas über den Einfluss Gottes anf die Handlungen der vernünftigen Geschöpfe. Graz, 1889.

Die Lehre des lll. Thomas iiber die Willensf reiheit der vernïnftigen Wesen. Graz, 1890.

Das Verhältniss der Wesenheit zu dem Dasein in den geschaffenen Dingen nach der Lehre des Thomas. Jahrb. Ph. sp. Th., 1890-92. Der neueste Commentator des hl. Thomas. Jahrb. Ph. sp. Th., 1891. Die potentia obedientialis der Creaturen. Jahrb. Ph. sp. Th., 1894. Die Neuthomisten. Jahrb. Ph. sp. Th., 1894-96.

Der Urstoff oder die erste Materie. Jahrb. Ph. sp. Th., 1897.

Das Werden im Sinne der Scholastik. Jahrb. Ph. sp. Th., 1904.

Das innerste Wesen der Sittlichkeit nach $S$. Thomas v. Aquin. Jahrb. Ph. sp. Th., 1904.

Fei.l, S.J., Georg. Die Unsterblichkeit der mensehliehen Seele philosophisch beleuchtet. Freiburg-i-B., Herder, 1892.

Fenet. La Faculté de Théologie de Paris. Paris, 1894.

L'aristotélisme et le cartésianisme dans l'université de Paris au XVII. siècle. Ann. Philos. chr., 1903.

Fersáxpez, F. Doetrinas jurídicas de Santo Tomás de Aquino. Madrid, 1888.

Fervíndez Concila, Rafael. Filosofía del Derecho, o Derecho Natural dispuesto para servir de introducción a las ciencias legales. 2. ed., Barcelona, 1887.

de Ferrari, G. Vita del beato Alberto Magno dell'ordine de'Predieatori. Roma, 1847 .

Ferrata, Axg. Osservazioni sulle leggi della conoseenza. Roma, Cuggiani, 1891.

Ferme, ('. M. Siant Thomas of Aquin and Ideology. London. 187.5: French, Paris, 1876.

Degli universali secondo la teoria rosminiana confrontata colla dottrina di San Tommaso d'Aquino. Casale, 1880.

linrreira-Decsidoo. la philosophie thomiste en Portugal. Rer. VéoScol., 1898.

Ferretti, S.J., Acg. Institutiones philosophia moralis. Ronie. 1887; 2. ed., 1895 .

Ferri, Lxigi. L'Aecademia romana di San Tommaso e l'istruzione filosofica del elero. Nuora Antologia, 2. serie, xxiv, 1880.

Ferris, J. On Right and Wrong. Irish Eecles. Rev., 1907.

Festugière. Questions de philosophie de la nature. Rev. bénéd., 1904. Fecerbacil, Llow. Abälard und Heloise. Ansbach, 1834; 4. ed., 1889. 
Fetgifray, II. R. Fssai sur les doetrines politiques de saint Thomas d'Aluin. l'aris, $185 \%$.

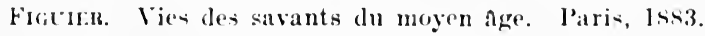

Fisicherta, A. Sin Tommaso d'Aquino, lane xlll e la scienza. ('atania, 1 sso.

Förds, B. A socializmus fejlödese. Budapest. 1903.

Folgners, O.P., J. I). La verite definie par saint Ansolme. Rev. Thom., 1900.

llasard on Providence. Le probleme des causes finales. Paris, Blond \& Barral, 1900.

Le libre arbitre. Rev. Thom., 1903.

Fol.girk, (.I., T. I). God's Happiness and Ours. Amer. Cath. Quart., 1907 .

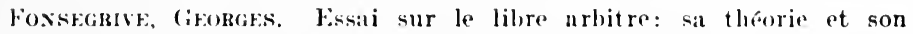
histoire. Paris, Alcan, 1887; 2. ed., 1896; Npan. ly (ionzález Carreño, Madrid, 1907.

Elements de philosophie. Paris, Picard, 1891.

La causalite efliciente. Paris, Alcan, 1893.

Fostaixf, Tir. De la sensution et de la pensée. Louvain, 1885.

Forget, J. I'n ehapitre inedit de la philosophie d' Aviconne. Rev. Néo-seol., 1 s94.

De l'influener de la philosophie arabe sur la philosophie scolastique. Rer. Néo-ścol., 1894.

Forsela, X. False Previsioni. Studio di psicologia scolastica. Rir. Filos., 1900.

Fox, JAMrs .J. Religion and Morality. Their Sature and Mutual Relations historienlly and doetrinally considered. New York, W. Il. Young \& Co., 1 s.99.

Scotus Redivivus. Jen lork Rere, 1905.

Fraxchi, Aisovio. I'ltima eritica. Milano, 1s89; 2. ed., 1890.

Foaxcisey, L. Az ethikiti daterminizmus es indeterminizmusrol. Böles. Foly., 1890.

A\% egyeduralmi kormany forma aquinoi szt. Tamás tana szerint. Boles. Foly., 1s?!

Az aktualizmus a lelektanlan. Büles. Foly., 1898.

Frs.ке, An. Gullaume Ockam et les Franciscains au XIV. siecle. C. R. Arat. seri. Mor. et I'ol., lstit.

lat Kabbale on la philosophie religiense des Habrenx. N. ed., Paris, lss9.

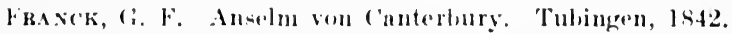

Frfontet forme et Matiare. latis, lsiti.

Freventur., J. Spinoza und die Scholastik. leipzig, 1887.

Zur lieurtheilung der Scholastik. Arehie f. Weschichle der Ihilos., Ins?0.

l'BEy, .J. A termenzetjog lóte. l'ées, 1904. 
Frick, S.J., Carolus. Logica. Friburgi, Herder, 1893; ed. 3., 1902. Ontologia sive metaphysica generalis. Friburgi, Herder, 1894; ed. 2., 1897

Frins, S.J., Victor. Thomx Aquinatis dectrina de cooperatione Dei cum omni creatura præsertim libera. Paris, Lethielleux, 1893.

De actibus humanis ontologice et psychologice consideratis seu disquisitiones psychologicx-theologicx de voluntate in ordine ad mores. Friburgi, Herder, 1897.

De actibus humanis moraliter consideratis. Friburgi, Herder, 1904. Frohscilammer, JakoB. Ueber das Recht der neuren Philosophie gegenüber der Scholastik. München, 1863.

Die Philosophie des Thomas von Aquino kritisch gewürdigt. Leipzig, 1889.

Frost, F. The "Art de Contemplacio" of Ramon Lull, published with an introduction and a study of the language of the author. Baltimore, 1903.

Gaborit, P. De la connaissance du beau. Paris, Bloud \& Barral, 1899.

Le beau dans les œurres littéraires. Paris, Bloud \& Barral, 1900.

Gabryl, Fr. Zum Begriff des Absoluten. Jahrb. Ph. sp. Th., 1902.

GaLDI, F. M. Institutiones philosophica complectentes logicam et metaphysicam. Bononiæ, 1893.

Gallovicir, E. Lêtért való küzdelem. Bölcs. Foly., 1904.

Garcia, O.P., Guillermo. Tomismo y. Neotomismo. San Luis Potosi, 1903 ; 2. ed., 1905.

El Seráfico Doctor San Buenaventura. San Luis Potosí, 1906.

Garcfa, M. F. Lexicon Scholasticum Philosophico-Theologicum in quo continentur termini, definitiones, distinctiones et effata a $B$. Joanne Duns Scoto Doctore Subtili. Quaracchi, 1906.

García Herrero, S.J., Cl. La libertad y el determinismo. Bilbao, 1903. García de los Santos, B. Vida de Balmes. Madrid, 1848.

GardaIr, J. L'activite dans les corps inorganiques. Paris, 1884.

La Matière et la Vie. Paris, 1885.

Les puissances de l'âme. Paris, 1886.

L'accord du libre arbitre avec la prescience et l'action de Dieu. Ann. Philos. chr., 1889.

Corps et ame. Essais sur la philosophie de saint Thomas. Paris. Lethielleux, 1892.

Les passions et la volonté. Paris, Lethielleux, 1892.

La Philosophie morale et la réforme sociale. Ann. de Philos. chrét., 1893.

Philosophie de saint Thomas: La Connaissance. Paris, Lethielleux, 1895.

Philosophie de saint Thomas: La Nature Humaine. Paris, Lethielleux, 1896.

Pensees philosophiques du Dr. Fournet. Paris, 1900. 
Gardonk, I. Les Vertus naturelles. Paris, Lethielleux, 1901.

Lal Philosophie et le Dogme. Ret. de Philos., 1902.

la formation des idees. Rev. de Philos., 1906.

lètre divin. leer. de Philos., 1906.

la transerndance de Dieu. her. de Philos., 1907.

L'infinite divine. Rer. de Philos., 1907.

Ginden, Ambis. Ifecolution et les principes do saint Thomas. Rev. Thom., 1893.

Ce qu'il y a de vrai dans le néo-scotisme. Rer. Thom., 1900-1.

(isknxk, Ancr. Studies in John the Scot (Erigena), a Philosopher of the Dark Ages. Iondon, Frowde, 1900.

Gabilio, Fr. B. Del sistema scientitico di San Tommaso d'Aquino. Sansevero, 1898.

(iarrigot-lagraxge, O.P., R. Le Dieu fini du pragmatisme. Rer. sci. philos. et the ol., 1907.

Les preuves thomistes de l'existence de Dieu critiquees par M. Le Roy. Rev. thom., 1907.

Intcllectualisme et liberté chez saint Thomas. Rer. Sci. Philos. et Theiol., 1907.

Le Pantheisme de la "Philosophie nouvelle" et la preuve de la transcendance divine. Rev. thom., 1:07.

(insqcet, J. R. The l'resent l'osition of the Arguments for the Existence of (iod. Dublin Rer., 1885.

Gavdexz. T. San Tommaso d'Aquino e la scienza. Bologna, 1874.

Gayacl. Horolyte. Le thomisme et le molinisme. Paris, Lethielleux, 1889.

Providence et libre arbitre lon saint Thomas. Exposition du thomiome. Toulouse, Privat, $18 \% 2$.

Matiere et Forme. Ann. de lhilos. chr., 1894.

saint Thomas et le predeterminisme. Paris, Lethielleux, 1895.

L'antisemitisme de saint Thomas d'Aquin. Paris, Dentu, 1896.

Questions du jour, politifues, socinles, religieuses, philosophiques. Paris, Mloud, ls!k.

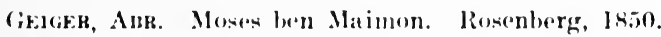

Gemkel.t. Ari. la volonta nel penxiero del Ven. (i. Duns Scoto. Scuola rattol., lage.

Del valore dellesperimento in prieslogia. Seuola. cattol., 1906.

Su un nowo indirizo della teoria dell'evoluzione. Scuola cattol., 1901 .

Il Kantismo di Duns seoto. La Vorma, 1907.

l'er il progremos degli ntudi scientifiei fra $i$ cattolici italiani. situdium, lator.

Grasab, P'. La cosmographie d'Allert la Grand d'apres l'observation et liesperiener du mogen nge. Ket. thom., lo0:-5. 
Gerdilius, H. S. Institutiones philosophicæ H. S. Gerdilii in usum seminariorum, nunc primum editæ studio Caroli Vercellone sod. Barnabitæ. Romæ, 1867.

Gerbard, Thomas J. Divine Personality. New York Rev., 1907.

Dichotomy: a Study in Newman and Aquinas. N. Y. Rev., 1908.

Getino, O.P., L. G. A. La Summa contra Gentes y el Pugio Fidei; carta sin sobre a D. M. Asín y Palacios. Vergara, 1905.

GEYsEr, J. Wie erklärt Thomas von Aquin unsere Wahrnehmung der Aussenwelt? Philos. Jahrb., 1899.

Lehrbuch der allgemeinen Psychologie. Münster, 1908.

Grbmons, J. C. The Philosophy of the Human Soul. London, Sands, 1908.

Gieswein, A. Az összehasonlitó nyelvészet föproblémái. Györ, 1891.

Beszed és gondolkozás. Bölcs. Foly., 1892.

Mit tartsunk a spiritisztikus jelenségek objektiv valódiságáról? Bölcs. Foly., 1904.

Gietmann, S.J., Gebard. Grundriss der Stilistik, Poetik und Aesthetik. 1897.

Gietmann, S.J., G. and J. Söbexsex, S.J. Kunstlehre. Freiburg, Herder, 1900.

Ginebra, S.J., Francisco. Elementos de Filosofía. Santiago de Chile, 1887 ; 2. ed., 1891; 1. ed. de Bogotá (with Introduction by Marco F. Suárez), 1893.

Elementos de Ética $y$ de Derecho Natural. Santiago de Chile, 1889 ; 3. ed., Barcelona, 1894.

Glossner, Michel. Die Lehre des hl. Thomas vom Wesen der göttliehen Gnade. Mainz, 1871.

Das objeetive Prineip der aristoteliseh-scolastische Philosophie, besonders Alberts des Gr. Lehre vom object. Ursprung der intelleetuellen Erkenntniss. Regensburg, 1850.

Der moderne Idealismus. Münster, 1880.

Das Princip der Individuation nach der Lehre des hl. Thomas und seiner Schule. Paderborn and Miinster, 1887.

Zur Frage nach d. Einfluss der Scholastik auf die neuere Philos. ophie. Jahr. Ph. sp. Th., 1889.

Die moderne Philosophie. Frankfurt-a-M., 1889.

Die philosophischen Reformversuche des Nikolaus Cusanus und M. Nizolius. Jahr. 1'h. sp. Th., 1889-90.

Die Philosophie des hl. Thomas v. Aquin. Gegen Frohsehammer. Jahr. Th. sp. Th., 1893-94.

Der Gottesbegriff in der neuen und neuesten Philosophie. Paderborn, Schöning, 1894.

Des Card. Pasmany Pliysik. Jahr. Ph. sp. Th., 1896.

Albert Barberis. Jahrb. Ph. sp. Th., 1898.

Phantasterci oder Schwindel? Jahrb. Ph. sp. Th., 1898. 
(inossirk, Mtchte. Seholastik, Reformkatholicismus und Reform katholische Philowephie. Jahrb. Ph. sp. Th., ls!l!.

liserskr, Jonx. Modern Seientific Views and Christinn Doctrines Compared. Milwaukie, lewdale, 1884.

leo Xlll and the Philosophy of St. Thomas. C'ath. World, lssi.

Medieval and Modern (osmology. Milwaukee, Hotrmann, Is9l.

Cosmacter, F. Lavenir de l'hypnose. Reflexions philosophiques, thoologiques. plyysiologiques sur la nature et les effets du sommeil provoque. Paris, Bauchesne, 1895.

Dialegues philosophico-theologiques sur la Providence. Paris, Beauchenene, 1896.

Limagination et les etats preternaturels. etude prycho-physio. logique et mystique. Blois, 1899.

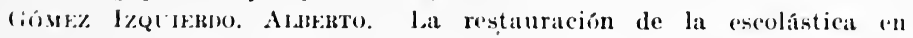
Francia. Rer. de Aragón, 1903.

la filosofáa escolastica en Alemania y otros paises. Rer. de Aragún. 1903.

El escolasticismo en Belgica. Rev. de Aragón, 1903.

La escuela filosotica de Lovaina. Ré de Aragón, 1903.

Ilistoria de la Filosoffa del siglo XlX. Zaragoza, 1903.

In filosofo catalín: Antonio Comellas y Cluet. C'ultura española. 1907 .

Nuevas direcciones de la lógicis. Madrid, Suárez, 1907.

(ioxmer, M. I'. De la méthode des sciences philosophiques dins les petits at les grands seminaires. Bayeux, 1905.

fioxzílez de: Arixtero, O.P., J. La evolución y la filosof́n cristiana. (iijon, 1s!s.

La Vrovidencia y la evolucion. Valladolid, Cucsta, I!004.

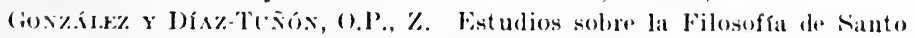
Tomás. Manila, 1864; 2. ed., Madrid, 1886.

l'hilosophia elementaria ad usum academica ac prasertim ecclesias tice juventutis. Matriti, Loperz, Intis; ed. 7., I894.

Estudios religioson, filomófeon, cientrfieos y soeiales. Madrid, lsaz.

Historia de la Filosoffa. Madrid, 1s79; 2. ed., 18st; French by (i. de Pascal, Paris, 1890-91.

Filosofia elemental. ti. ed., Madrid, 1894.

La Biblia y la cieneial. Mndrid, Is!l.

Gossand, .11. Linfaments d'une synthere scolatstique des morurs. Rer. de Philos., lagti.

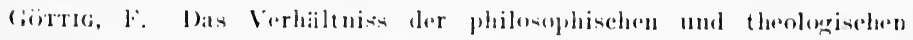
Tugroden, mit Kugrundlegmegr der Tugendlelire des Thomas v. Apuin. Kirl, 1sito.

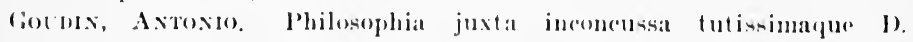

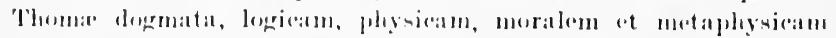

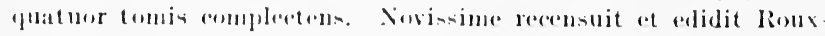
lawerene. l'arisiin, lsit; n. al.. Istil. 
Gours, A. Elements de Philosophie chrétienne. Paris, Lethielleux.

Goujon, H. Kant et Kantistes; études critiques selon les principes de la metaphysique thomiste. Lille, Morel, 1901.

Les ennemis de la raison, la philosophie de la volonté et l'apologie de l'immanence. 1904.

Grabmaxx, Martin. Streifliehter iiber Ziel und Weg des Studiums der thomistischen Philosophie mit besonderer Bezugnahme auf moderne Probleme. Jahrb. Ph. sp. Th., 1899.

Der Genius der Schriften des hl. Thomas und die Gottesidee. Paderborn, 1899.

Dr. Franz P. v. Morgott, als Thomist. Jahrb. Ph. sp. Th., 1900.

Die Lehre des Johannes Teutonicus O. P. ueber den Unterschied von Wesenheit und Dasein. Jahrb. Ph. sp. Th., 1902.

Die philosophische und theologische Erkenntnisslehre des Kardinals Matthäus von Aquasparta. Wien, 1906.

Granato, F. I principii dell'ateismo contemporaneo e San Tommaso d'Aquino. Napoli, 1877.

Graxdclaude. Breviarium philosophia scholasticx. Paris, 1868; 8. ed., 1886.

de Grandmason. Sur l'apologétique de saint Thomas. Youvelle Rev. Théol., 1907 .

Grent, O.S.B., Jos. Das Erkennen. Jahrb. Ph. sp. Th., 1898.

Elementa philosophiæ aristotelico-thomistice. Romæ, $1899 \mathrm{ff}$.

Homogénéité ou hêtérogénéité du mixte. Rev. Néo-scol., 1907.

Grimmicil, O.S.B., Virg. Lehrbueh der theoretischen Philosophie auf thomistiseher Grundlage. Freiburg, Herder, 1893.

van de Groot, O.P., J. Het leven van den H. Thomas van Aquino. Utrecht, Van Rossum, 1882.

Summa apologetiea de ecclesia catholica ad mentem S. Thom Aquinatis. Regensburg, 1890.

De philosophia S. Thomæ Aquinatis. Div. Thomas, 1890-91.

De auetoritate Aristotelis. Div. Thom., 1891.

De h. Thomas van Aquino als wijsgeer. Amsterdam, 1894.

Saint Thomas d'Aquin et sa plilosophie. Rev. thom., 1894.

Leo X111 en de H. Thomas van Aquino. Utreeht, 1895; German by B. J. Fuss, Regensburg, 1897.

Levenswijding. Drie voordrachten uitgesproken te Leuven voor het Sint-Thomas Genootschap der Studenten van de katholieke Hoogeschool. Amsterdam, 1900.

Het leven van den $h$. Thomas van Aquino. tweede geheel herziene druk. Etrecht, 1907 .

Grossmaxi, Lovis, Maimonides. New York and London, Putnam, 1890.

Gruber, S.J., Hermaxi. Angust Comte, der Begründer des Positivismus. Sein Leben und seine Lehre. Freiburg, Herder, 1899; French by Mazoyer, Paris, Lethielleux, 1892. 


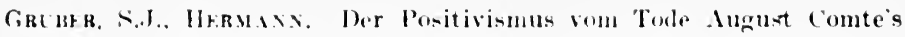
bis auf unsere Thage. Freiburg. Herder, lsigl; French ly Mazoyer, Paris, Lethielleux, 1893.

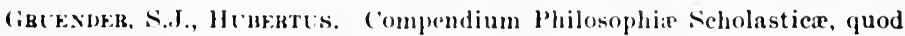
nostris collegiis aceommodavit P. H. Giruender, S.J., Lector Philosophia in Collegio Sti. Joannis, Toledo, O. Vol. 1. Dialectica et Critica. For private circulation only.

Grixwald, (irokg. (ieschichte der (iottesbeweise im Mittelalter bis zum Ausgung der Hochscholastik (Beitriige). Münster, 1907.

(ivabsixis, (i. Della umana felicita secondo la dottrina di san Tommaso d'Aquino. Treviso, 1883.

(itexrix, (i. Le' libre arbitre. Rev. de Philos., 1906.

(icilleksix. Saint Thomas et le predeterminisme. Paris, 1895.

Guzot, F. P. (i. Abuilard et Helö̈se, essai historique. Paris, 1839.

Gicthikiet, (oxstaxtix. Das Inendliche metaphysisch und mathe. matisch betrachtet. Mainz, 1878.

Das liesetz von der Erhaltung der Kraft u. seine Erziehungen zur Metaphysik. Münster, 1882.

Die reue Rumntheorie. Mainz, 1882.

Die Descendenztheorie auf Logik und Thatsachen geprïft. 1887.

Die Aufgabe der christlichen Philosophie in der Gegenwart. Philos. Jahrb., less.

Der Kampf um die Willensfreiheit. Philos. Jahrb., 18s9-91.

Lehrbuch der Philosophie. 2. ed., Münster. 1s90; 3. ed., 1897.

Logik und Erkenntnisstheorie. 3. ed., Mïnster, Theissing, 1898.

Allgemeine Metaphysik. 3. ed., Münster, Theissing, 1897.

Naturphilosophie. 3. ed., Mïnster, 1900.

Die Prychologie. Miinster, 1896.

Die Theodiere. Miinster, Theis-ing, 1890; 3. ed., 1897.

lithik und Naturrecht. 3. ed., Minster, 'Theissing, 1901.

Ethik und Religion. Minster, 1s!2.

Der mechanische Monismus. Paderborn, 1893.

Die Willensfreiheit und ihre Gegner. Fuldn, 1893; 2. ed., 1907.

'Thomas von Aquin und Jmmanuel Kant. Der Kath., ls93.

lst die Siele Thiitigkeit oder Substanz? Philos. Jahrb., 1896.

Der Mensch, sein Crrsprung und scine Entwickluner. Paderborn, 1896.

Der Kampf um die Seele. Vortrige iller die brennenden Fragen der mod. Psychologie. Mainz, Kirchheim, 1899.

Teleologire und ('unsalitiit. Philos. fahrb., l900-1.

Eine nene actunlistische Serelentherie. l'hilos. Jahrb., 1901.

Der Voluntarismus. Philos. Jahrb., l:03.

Eine Jithik des freien Wollens. I'hilos. Jahrb., 1906.

Die Substanz als lbewegungsmelodie. Philos. Jahrb., lagt.

14.r gegenwärtige stand der peychologischen Forschung. Philos. Jahrb., lags. 
Gutrmax, J. Die Philosophie des Salomon ibn Gabirol (Avicebron) dargestellt und erläutert. Göttingen, 1889.

Das Verhältniss des Thomas von Aquino zum Judenthum und zur jiidischen Literatur. Göttingen, 1891.

Die Scholastik des XIII. Jahrh. in ihren Beziehungen zum . Judenthum. Breslau, Mareus, 1902.

Guyeton, L. L'argument de saint Anselme. Ann. Philos. chr., 1894. HAax, S.J., HeIxr. Philosophia naturalis in usum scholarum. Friburgi, Herder, 1894 ; ed. 3., 1906.

HaAs, Jor. Moralstatistik und Willensfreiheit. Jahrb. Ph. sp. Th., 1898.

Die immaterielle Substantialität der menschlichen Seele. Regensburg, 1903.

Ceber den Untersehicd, näherhin über den Unterschied von Wesenheit und Dasein. Philos. Jahrb., 1905.

HaBRich, J. Leven en Ziel, twee voordrachten vertaald uit het duitsch door G. Simeons. Brugge, 1907.

Hadzsega, B. Lenytan. Ungvär, 1904.

Haffner, Paul. Grundlinien der Philosophie. Mainz, 1881-84.

Hagemaxn, Georg. Elemente der Philosophie. 1. Theile. Logik und Noetik. 2. Theil. Metaphysik. 3. Theil. Psychologie. 6. ed., Freiburg, Herder, 1894-97.

Haix. Almarich von Bena. Theol. Studien u. Kritiken; Hamburg, 1846.

Hain, S. Thomas Bradwardinus und seine Lehre von des menschlichen Willensfreiheit (Beiträge). Münster, 1905.

HaHx, Wilir. Die Entstehung der Weltkörper, im Sinne der bezügliehen Rundschreiben Leo's XIII untersucht und für Gebildete aller Stïnde beleuchtet. Miinchen, 1895 .

HaJós, A. Altalános psychopathologia. Budapest, 1904.

Hallecx, Jeax. Jes principes du positivisme contemporain. Exposé et eritique. Louvain, Peeters, 1897 .

L'érolutionisme en morale. Paris, Alean, 1901.

Les Preuves de l'existence de Dieu. A propos d'un livre récent sur l'existence de Dieu. Rev. Néo-Scol., 1906-7.

Hammerstein, S.J., L. Ciottesbeweise. Eine Ergänung zu Edgar oder vom Atheismus zur vollen Wahrheit. Trier, 1891.

Hamplex, Revi Dicksos. The Scholastic Philosophy in its Relation to Christian Theology. Oxford, 1832.

Ifaxemerg, 13. Zur Erkenntnisslehre des Ibn Sina und Albertus Magnus. Abhandl. d. philos. philol. (1. der k. bayer. Akad. d. Wiss., Miinehen, lstiti.

Hargrove, C. Saint Thomas Aquinas. Mod. Rev., 1880.

InARIR, S.J., Thomss. Evidenee and Certainty in their Relation to conceptual Truth. Manchester, 1876. 


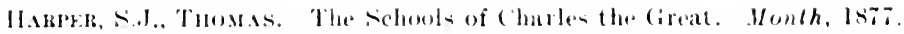

The Enegrlical. $1 / \mathrm{cmth}, 1 \mathrm{sig}$.

The Metaphysice of the schools. London, 1sig-st.

The Word. Mind, lssis.

From logic to God. Inulin Rer., Isst.

Hatersax, F. Die sinnliche Wahrnehmung nach Pierre d'Ailly. Philos. Jahrb., 19103.

Hasse, Fr. Rid. Anselm von (anterbury. Leipzig, Ist3-5z; Engl. by W. Turner. Londen, Is50.

1). ontolugico Anselmi pro existentia Dei argumento. Bonn, 1849.

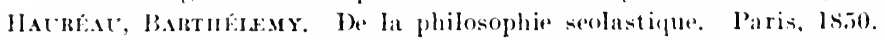

Hugues de Saint-Vietor. Nouvel examen de l'élition de ses aured. arec deux opuseules inedits. Paris, lsis?.

Histoire de la philosophie seolastique. Paris, 1872-80.

les arures de Hugues de Saint-Victor. Essai eritique. Paris. Hachette. 1ssi.

Des poemes latins attribues a saint Bernard. Paris, 1890.

Notices et extraits de quelques manuscrits latins de la Bibliotheque Nationale. Paris, Is9l.

Hatsmath, A. Peter Abilard. Win lebenshild. leipzig, 1s93.

Havaty. Analyse der Philosophie des hl. Thomas von Aquino. I8s.).

HaYd, H. Abiilarel und seine Lehre. Regensburg, lisis.

Hraker, I. T. The True and the False Friends of Reason. 'ath. World, lissl.

Thomistic-Rosminian timersonianism: or "A Religion for Italy." r'ath. Horld, 1sist.

Hrote, R. Ralations des sciences profanes ave la philosophie et la theologre. Rer. thom., 1903-5.

Nominalisme at liealisme. Rev. thom., 1907.

Hemsax, K. Der substanzhegriff von Abälard bis spinoza. Berlin. 1590.

Hr.tт. Tи. La Philosophie et la Foi dans l'auve d'Abelard. Ret. sici. l'hilos. et Theol., 1907.

La philesephie et la foi che\% les disciples d'Abehnrd. Ker. sci. phi. it theol., 1908.

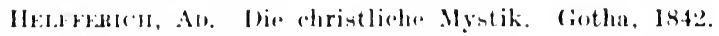

Raymumdur lollus. Barlin, lisis.

Hras, ('. J. Die Erechelnung der Dinge in der Wahrnehmung. Dape rip, $\mid \mathrm{lisi}$.

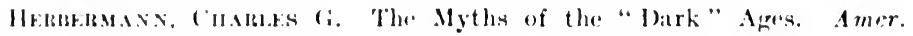
('ath. ()utht., listit.

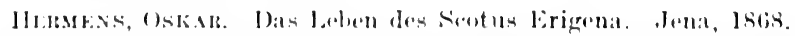

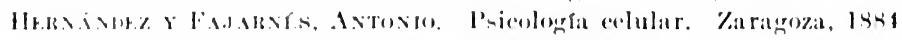

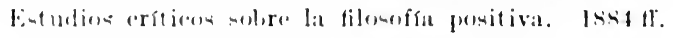

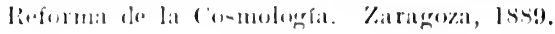


Hernández y Fajariés, Axtoxio. Principios de Metafísica: Ontología, 1887 ; Psicología, 1889; Cosmología, 1893.

Programa de lógica fundamental. Madrid, 1906.

Principios de lógica fundamental. Madrid, 1906.

ron Hertling, G. F. Albertus Magnus und die Wissenschaft seiner Zeit. Histor. pol. Blätter, 1874.

Albertus Magnus. Beiträge zu seiner Würdigung. Köln, 1880.

Descartes' Beziehungen zur Scholastik. München, 1899.

Christenthum und griechische Philosophie. München, 1901.

Herwig, EMIL. Ueber den ontologischen Beweis. Rostock, 1868.

Hettinger, Fr. Thomas von Aquin und die europiiische Civilisation. Frankfurt-a-M., 1880; 2. ed., 1898.

'Timotheus, Briefe an einen jungen Theologen. Freiburg, 1897; Engl. by V. Stepka, St. Louis, Herder, 1902.

Hetrwer, JoIr. De fidei et scientiarum discrimine et consortio juxta mentem Hugonis a Sancto Victore. Vratislaviæ, 1875.

Hewrt, C.S.P., A. F. The Christian Agnostic and the Christian Gnostic. Amer. Cath. Quart., 1891.

The Stonyhurst Philosophical Series. Cath. World, 1891.

The Theodicy of Aristotle. Amer. Eccles. Rev., 1892-93.

The Essential Goodness of God. Cath. World, 1893.

Hickey, J. S. Summula philosophiæ scholastice in usum adolescentium Seminarii Beatæ Mariæ de Monte Melleario concinnata. Dublinii, 1902-5.

HrLr, S.J., Walter H. Elements of Philosophy, comprising Logic and Ontology, or General Metaphysics. Baltimore, 1873.

Origin of Ideas; or, concerning the manner and the order in which the human mind naturally acquires knowledge. What philosophical system most faithfully describes the operation of the mind in thinking? Amer. Cath. Quart., 1876.

Can the Immateriality, Spirituality, and Immortality of the Human Soul be Demonstrated? Amer. Cath. Quart., 1877.

Ethics, or Moral Philosophy. Baltimore, Murphy, 1878; tth ed., 1896.

The Human Soul and Body. Their union considered with reference to different theories for explaining the nature of material substance. Amer. Cath. Quart., 1879.

Number of the External Senses: What use man's reason can make of their manifestations as data. Amer. Cath. Quart., 1891.

Conscious Aets. Amer. Cath. Quart., 1892.

HıLL, T. John Scotus Erigena. Christ. Exam., xlvi.

Hrrscir, B. A. Roger Bacon as an Hebraist. Jewish Quart., xii.

HJort, PEter. Johann Scotus Erigena, oder von dem Ursprung einer christlichen Philosophie und ihrem heiligen Beruf. Kopenhagen, 1823. 
Horfmaxs, F. J. Der Gottes- und Schöpfungsbegriff des Joh. Scotus Erigena. Jena. 1876.

Hormasx, P. Hanelix. La synthese doctrinale de Roger Bacon. A rehir f. Gissh. der Philos., 1907.

Hofmaxx, R. De Johannis Scoti Erigence vita et doctrina. Halle, 1877.

Hogax, J. B. Clerical Studies. Boston, 1899; Ital. by P. Perciballi, with Introd. by P. Semeria; French by A. Boudinhon, with Introd. by Mgr. Mignot: Paris, Lethielleux, 1901.

Ḧ̈gL, M. Vernunft und Religion. Mit oberhirtlicher Druckgeneh. migung. Regensburg, 1901.

Höнse, AEshrr's. Anselmi ('antuariensis philosophia cum aliorum illius atatis decretis comparatur ejusdemque de satisfactione doctrina dijudicatur. Leipzig, 1867 .

Holaixn, S.J., Rf.se I. Natural Jaw and Legal Practice. Ifectures delivered at the Law School of Georgetown University. New York, Benziger, 1899.

Holmero. Fr. De theologia naturali Raymundi de sabunde. Halo, 1843.

Hot.t.sibrg, W. A. Studien zu Bonaventura. Berlin, 1862.

vos HowtM, O.S.B., GRegor. Zur logischen Lchre vom Satze. Jahrb. Ph. sp. Th., 1894.

Philosophisch-theologische Aphorismen. Jahrl. Ph. sp. Th., ls!n. Die Natur der Seelensubstanz und ihrer Potenzen. Jahrb. I'h. sp. Th., 1900.

Thierisches und menschliehes Erkennen. Thilos. Jahrb., 1901.

Das Anernehme und das Gute. Philos. Jahrb., 1904.

Die scholastische Philosophir in ihrem Verhältniss zu Wissensehaft. Philosophir und Theologie, mit besond. Berileksichtignng der modernen \%eit. Philos. Jahrl., 1905-6.

Iloxtukim, S.J., los. Institutiones theodicare sive theologia naturalis secundum principia S. Thome Ayuinatis ad usum scolnsticum. Friburgi Brisgoviar. Herder. 1893.

Der logische Algorithmus in seinem Wresem, in seiner Anwendung und in seiner philosophischen Bedeutung. Berlin, 189.5.

Hoper, (\&. Dir Paychologie des J. L. Vives. Berlin, Mayer \& Miiller. 1901 .

Hotrcane, Remt. Essence et existenes, a propos d'un liver réent. Bu. l. erel., 1908 .

Hrber, Jousxies. Johannes Scotuy Erigena. Fin Beitrag zur Go schichte der Philosophie und Theolegie im Mittelalter. Minchen. Intil.

Homer. Ser. Die Gilick weligkeitalehre des Aristotelos und hl. Thomas von Aquin. Ein historisch-kritinchrer Vergloich. Freising. 1893.

Grundzijge der logik und Nowtik im Geiste des hl. Themas von Ayuin. Paderborn. Serhöningh, loget. 
Hïnner, J. Az exakt tudományok problémai. Böles. Foly., 1893.

Alvás és álom. Bälcs. Foly., 1900.

Heet, Fraxcois. Recherches historiques et critiques sur la vie, les ouvrages et la doctrine de Henri de Gand. Gand, 1838.

Hugox, O.P., ED. Cursus philosophise thomisticx. Paris, Lethielleux, $1906 \mathrm{ff}$.

voN Hügel, Fr. Experience and Transcendence. Dublin Rev., 1906.

Hugries, S.J., Thomas. Biology, or the Principle of Life. Amer. Cath. Quart., 1881.

Hugonis. De materia et forma apud S. Thomam. Paris, 1854.

Huguery, E. A quel bonheur sommes-nous destines? Rev. thom., $1905-6$.

Hrit, Cri. Le Platonisme au moyen âge. Ann. Philos. chr., 1889.

Les Arabes et l'aristotélisme. Ann. Philos. chr., 1889.

La philosophie du moyen âge. Enseignement chr., 1900.

La philosophie de la nature chez les anciens. Paris, 1901.

D’Hulst, Macrice. Mélanges philosophiques. Paris, 1892.

Humpirey, S.J., Wilimam. Conscience and Law or Principles of Human Conduct. 2d ed., London and New York, 1903.

Hunxaeus, J. D. Thomæ Aquinatis totius Summe Theologicx conclusiones. N. ed., Paris, Roger \& Chernoviz, 1890.

Hurter, S.J., II. Patrum Sanctorum opuscula selecta ad usum præsertim studiosorum theologiæ, Commentariis aucta. Eniponti, 1868.

Los derechos de la razón y de la fé. Traducción del original alemán por D. J. M. Ortí y Lara. Aguascalientes, 1894.

Huttrer, M. Die Religionsphilosophie des Raym. von Sabunde. Augsburg, 1851.

HuYs, I. La notion de substance dans la philosophie contemporaine et dans la philosophie scolastique. Rev. Néo-Scol., 1898.

Inn Grbirol (Aven-Cebroi.). La fuente de la vida. Traducida en el siglo XII. por Juan Hispano Domingo Gonzalez del árabe al latin y ahora por Ia. vez al castellano por F. de Castro y Fernández. Madrid, Serra, 1901.

IIGXer, C. Dic wirtsehaftlichen Ansehauungen Antonius von Florenz (1389-1459). Paderborn, Schöning, 1904.

liligens, Ebzrnard. Die unendliche Menge. Philos. Jahrb., 1889-90.

Isenkrahe, C. Ти. Idealismus oder Realismus? Leipzig, 1883.

Die Objectivitiat und die Sicherheit des Erkennens. Philos. Jahrb., 1893.

Der Begriff der Zeit. I'hilos. Jahrb., 1902-3.

Iterria, S.J., Greq. Compendium Metaphysice eximii Doctoris Franeisci Suarez. S.J. Madrid, Fontanet, 1901.

IACCord. Elementa philosophia theoretice et practice. Friburgi, 1892.

JacQux, O.P., M. Le néo-platonisme de Jean Scot. Rev. Sci. Philos. et Theol., 1907 . 
IE: JAFGHer, E. Institutiones philosophicer. Rollarii. I?00.

IAnvil. De conseientiar notione, qualis furrit apud reteres at apud

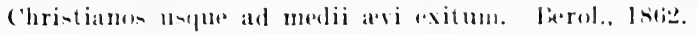

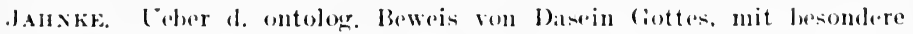
Beriackichtigung von Anselm und bescartes. Stralsund, 1sit.

Isxaschek, l.top. Bibliographia Bernardina, qua sancti Bernardi, primi abbatis ('latavallensis, operom com ounium lum -ingulorum editiones ac versiones vitas et tractatlls do en seriptos

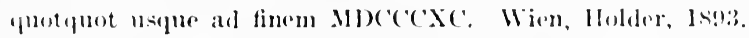

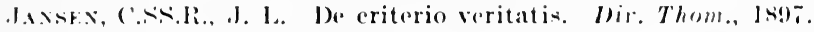

Disputatio eritiea de distinctione virtuali inter esentiam el exist(ntiam. Jahrb. Ph. sp. Th., lsgs.

(ieschichte und Kritik im Dienste der "Minus probahilis." l'aderborn, 1906.

Jaxsex, Jomaxis. Der hl. Thomas von Apuin, Kevelacr, Ists.

Inssixs, b. Le né-eritioisme de Charles Renouvier. Theorio de la connaissance et de la certitude. Lowain. 1904.

la philonophe et lapologétipue de Pastal. Louvain, 190ti.

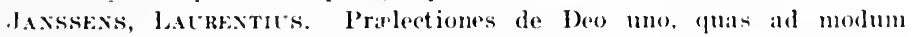
commentarii in summam Theologicam Divi Aquinatis habebat in

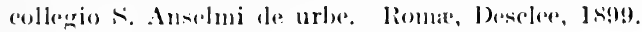

IAwirk, O.P. Laction intellectuelle et politique de laton Xlll. Parix, lecoltre, 1902.

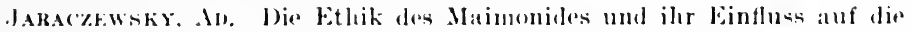
scholastinche Philosophio des I3. Jahrh. Zeitsch. f. Mhiles. u. philos. Kritik, latis.

Jasprer. Lejhniz und dio Schelantik. Loiprig. lsos.

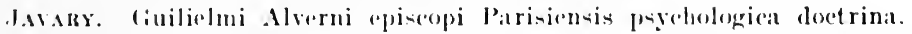
Aureliar, 1siol.

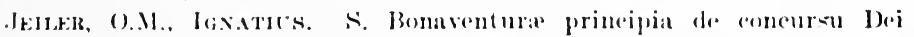
generali ad actiones callsarum secundarmu collecta et $t$. Thoma doctrina confirmata. Ad claras Aquas, ls!ot.

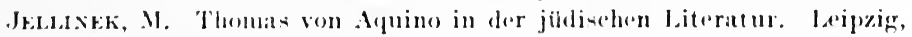
1 1.i.3.

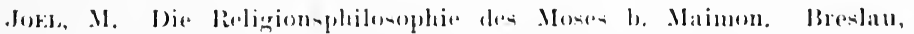
18.i?.

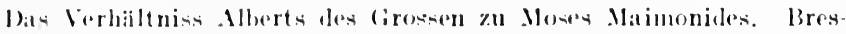
lau, Isitis.

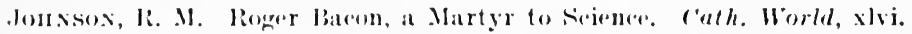

Jocts, s.J., lotes. Preclectiones dre lure Naturali habita in collegio S. Join. Fordh. lstio 61 .

Elementa Philomphia Moralis. Ambiani, Lambert-Caron, 1stis; al. 4., Non bubraci, Banziger, lssti.

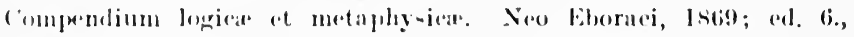
$15 !)$. 
Jours, S.J., Lovis. The Study of Philosophy. Leeture delivered before Regents of New York. 1869.

Logic and Metaplyysics. New York.

Joubdan, Charles. La philosophie de saint Thomas d'Aquin. Paris, Hachette, 1858.

Judgr, Thomas E. The Alphabet of the History of Philosophy. Rev. Cath. Ped., 1903.

The Nature of the Soul. A Study in Elementary Psychology. Rev. Cath. Ped., 1903.

Jundt. Histoire du panthéisme au moyen age. Paris, 1875.

Jungmann, S.J., JosePir. Aesthetik. Freiburg, Herder, 1884; 3. ed., 1866.

KacinıK, Jos. Dissertatio philosophica, quam usibus Theologise studiosorum concinnavit. Olmiitz, 1892.

De natura entis. Olmiitz, 1892.

Historia philosophiæ. Olmiitz, 1896.

Kádír, A. A valódi természetböleselet szelleme. Böles. Foly., 1887.

Kaderavek, Ecgex. Die menschliche Seele an sich betrachtet. 1883.

Vergleiehung der christ. Philosophie mit einigen Philosophien der Neuzeit. 1885.

Das Urtheil. Jahrb. I'h. sp. Th., 1890.

Ueber die Einfuhrung der christlichen oder aristotelischthomistischen Philosophie an den philosophischen Facultaten. Philos. Jahrb., 1890.

Psychologie. 1894.

Kaiser, Emile. Pierre Abélard eritique. Fribourg-en-Suisse, 1901.

Kampmaxx. Philosophia angelico-seraphica. Quaracchi, 1896.

Kantonowicz, H. Albertus Gandinus und das Strafrecht der Scho. lastik. Berlin, Guttentag, $1907 \mathrm{ff}$.

Kármín, P. Anyag es szellem. Budapest, 1894.

Kaufmaxn, David. Studien über Salomon Ibn Gabirol. Budapest, 1899.

Kaufmann, Nikolaus. Vervollkommnung der aristotelischen Naturphilosophie. Iucern, 1883.

Bedeutung eines philosophischen Principes: Der Akt ist früher als die Potenz. Lucern, 1886.

Die Erkenntnisslehre des hl. Thomas von Aquin und ihre Bedeutung in der Gegenwart. Philos. Jahrb., 1889.

Bedeutung der Philosophie in der Gegenwart. Frankfurt-a-M.. 1889.

Das Causalitatprincip und seine Bedeutung für die Philosophie. Fulda, Actiendruckerei, 1891.

Die teleologisehe Naturaufassung des Aristoteles und ihre Bedentung in der Gegenwart. Paderborn, 2. ed., 1893 .

Elemente der aristotelischen ()ntologie. Mit Berücksichtigung der 
Weiterbildung durch den hl. Thomas v. Aq. und neuere Aristoteliker. Lueern, 1s!)

Katran, Nikolils. (hrintliche Moral und moderne atheistische Fthik. Lucern, 1898 .

Die Begrüdung der Sichönheit nach der lehre des Aristoteles und des Thomas v. Aquino. Kath. Schw. Bl., ii.

Die l'hilosophie des hl. Thomas und die Cultur der Neuzeit. Schue. hirchenzeitung, 1901.

1)as Pontificat leos $\mathrm{X} 111$ und der Neuthomismus. Siche. Kirchen. zeituny, 1902.2 .

La finalite dans loodre moral. Louvain, 1899.

Philosophie nifturelle d'Aristote. Ftude de la cause finale et son importanee au temps présent (trad. par A. Deiber). Paris, Al':an, 1898.

Katrich, Winzm. Das speculative System dey Johannen Seotus Erigena. Prag, 1860.

Scotus Erigena. Abhandl. d. böhm. Gesell. d. Wiss., 1861.

Gesehichte der scholastischen Philosophie. P'rag, Isti3.

Die Lehre des Hugo und Richard von st. Vietor. Alhandl. a. bohm. (iescll. d. Wiss., 1.u.,-64; l'rag, 1865.

haltas, R. Die Lehre rom gerechten Preis in der Scholastik. Separat. abdruck aus der Zeitschrift für die gesamte stautsurssenschaft. Tübingen, Laupp, 1944.

KEARxEY, (I.P'.. L. F. P'roofs of the Existence of God drawn from the Metaphyical or Idend ()rder. Amer. ('ath. Quart., 1891.

The "A simultanes" Proof of the Existence of fiod. Amer. Eircles. lier., 1s!2:

What we (Jwe to the Summa of St. Thomas. Rosary, 1s93.

Kelt.e, J. Cober llonorius Auguntedunensis und das Elucidarium sive Dialogus de summa totins christianae theologine. Wien, 1901. Contersuchungen aber das speculum Eeclesian des flonorius und die libri deflorationum des Alites Werner. Wien, I!nez.

Entersuchungen ibler das ()frendienlum des llonorius, sein Ver. lateltniss zu dem gleichfalls einem Honorius zugeschrieben Euchariation und Elucidarius wowio zu den deutschen fiedichten Gichugelo und l'fatronleben. Wien, l!not.

Interounehumen biher des llonorins Inevitabile sive de Pracdestina tione et libero arbitrio dialegent. Wien, 190.5.

lontersunchungen iiler den nicht natehweisharen Honorius Angusto-

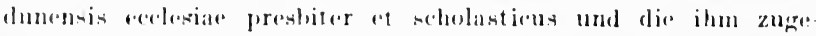
schriebenen Werke. Wien, lans.

Coter-nchungen ijher den nicht nachweisharen flonorius Augusto dunensiu. Nachtrag. Wien, lagti.

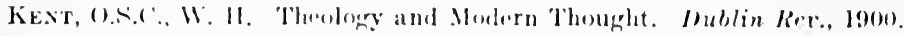

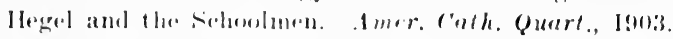

St. Thomats and the Irat, Nou Platunists. Amer. Cath. Quart., 1901. 
Ketller, J. M. L. Saint Thomas. De hatholick, 1897.

hilgexsters, Jakob. Die Gotteslehre des Hugo von St. Victor nebst einer einleitenden Lntersuchung ïber Hugo's Leben und seine hervorragendsten Werke. Würzburg, 1898.

hIss, I. XIll Leo körlevele a keresztény szellemü böleselct visszaállitása érlekeben. Bölcs. Foly., 1886.

A szervetlen testek lényegéröl. Bölcs. Foly., 188ð.

Rövid tájékoztató a scholasticus böleseletröl. Bölcs. Foly.. 1891.

A lény fogalmáról. Bölcs. F'oly., 1892.

A lény füelveirül. Lényeg és létezés. Bölcs. Foly., 1893.

Az éllettelen és az élö anyag jellegzése. Bölcs. Foly., 1894.

A szépröl és a szepmüvészetekröl. Budapest, 1904.

KLeEkaмm, J. Die menschliche Seele, ihre Geistigkeit und Cnsterblichkeit. Heiligenstadt, 1897 .

Kleiber. C. C. L. De Raymundi vita et scriptis. Berolini, 1856.

KLetTgex, S.J., Josepir. Institutiones philosophiæ practice in usum prolectionum. Friburgi Helvetiorum, 1837.

Die Philosophie der Vorzeit. Insbruck, 1860-63; 2. ed., 1878-79; Ital. by Reisach and Curci, Roma, $1866 \mathrm{ff}$; French by C. Sierp, Paris, Gaume, 1868-70.

L'ontologismo e le sette tesi censurate dalla Sacra Inquisizione. Roma, 1867 .

Beilagen zu den Werken ïber die Theologie und Philosophie der Vorzeit. Erstes Heft: Ieber die Verurtheilung des Ontologismus dureh den H. Stuhl. Miinster, 1868.

2. Heft: $\mathrm{Zu}$ meiner Rechtfertigung. Mïnster, 1868.

3. Heft: 1. Fom intellectus agens und den angebornen ldeen.

2. Zur Lehre vom Glauben. Mïnster, 1875.

De ipso Deo. Regensburg. Pustet, 1881.

Ueber den Irsprung der menschlichen seele. Zeitsch. f. kath. Theol., vii.

Klimke, S.J., Friedr. Die Philosophie des Monismus. Jahrb. Ph. sp. Th., 1907 .

Kxabexuat tr, S.J.. J. Das \%eugniss des Mensehengeschlechtes für die Insterblichkeit der Seele. Freiburg, 1888.

Kxarer, V. Grundlinien zur aristoteliseh-thomistischen Psychologie. Wien, 1885.

Kxem, Puntrp. Die Willensfreiheit und die innere Veratwortlichkeit. Mainz. Kirchheim, 1899.

Die Lnsterblichkeit der Seele, bewiesen aus denı höheren Erkennen und Wollen. Fin Beitrag zur Apologetik und zur Wiirdigung der thomistischen Philosophie. Wien, Mayer, 1900.

Kxoont. l'eter. Die Tliomas Encychea Leos XIII vom 4 August 1879. Vortrag gehalten zu Bonn am 14 Februar 1880. Bonn, 1880.

K̈̈ist, Jis. Petrus Lombardus in seiner Stellung zur Philosophie des Mittelalters. Greifswald, 1597. 


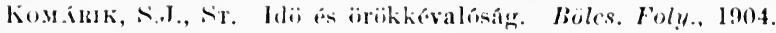

horproll. HкRм. Die Verwaneltschaft Leibnizens mit Thomas von Aquino in der lehre vom Böse'n. Jena, 1s92.

Kökrer, I. Dits ontologische Argument. Bitmlerg, 18s4.

kovics l.A.Jos. A kerestény llitvelelem AB('-je. 'Temesvar, 1903.

Kozíry, I. Az inductio és az iskolia. Böles. Foly., lssi.

A vilígtani en céltani êr ertelme nehany ellenvetes ellen. Böles. Foly., lsis.

Korunk bïleselete. P'ers, 1892.

A hypotiamuarol. Boles. Foly., 1892.

Wumlt rendszerenek ismertetese es biránta. Böles. Foly. 1897.

Kваммғв, (i. Az allam es az allamhatalomrol. Böles. Foly., 18!96.

lsten miikïlese a teremtett vilagban. Bölcs. Foly., 1902.

Kratst, fos. Bonaventura te origine et via cognitionis intellectualis doetrina ab ontologismi nota defensa. Monasterii, Isis.

Die leche des hl. Bonaventura iiker d. Natur der kïrperl. u. geistigen Wesen und ihr Verhiiltnise zoum Thomismus. Pader. born, lstis.

Quomodo s. Bonaventura mundum non esse atermum, sed tempore ortum demonstraverit. Brannelerg, lsol.

$\therefore$ Benaventuram in doetrina de rerum naturalimm origine $s$. Alyontinum secutum esse. Braunsherg, ls!l4.

kiksts, E. Ftudien iber Meister Dietrich genannt von Freiburg. Frei burg-i B., 1!103.

Meintar Dietrich ('Theodoriene Toutoniens de Vriberes). Sein Leben,

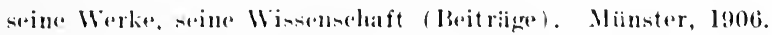

Keogll-Tosise, K. In gratia ('hristi et de libero arbitrio saneti Thomar Ayunatis dectrina. ('hristiania, Is9s.

Der letzte ficholatiker. Froburg, Herder, lont.

Köivats. Amalrich ron Benal und lavid von Dinnut. Hamburg, 1847.

Kвog, II. De pulchrituline divina libri tres. Friburgi Brisg., Herder, I90:2.

kiss. Gianken mul Wisnen nach Thomas von dquino. Tiub. theol. Quart.. Istiot.

Philosephiate mal Theologiate. Tiibingren, Intolo.

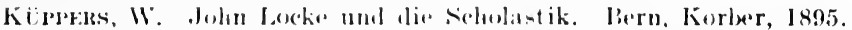

Kuntu, (ionflemen. Die Arbeitur. Linigungen des Mittelalters (transl.

from the French by $A$. IAimbach). Fulda, 189.4.

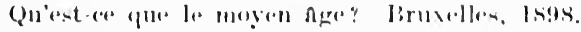

lanmsst, II. liecherches mur la vie et leavere de Nicolats de lire. Touloume, l'rivat, I!)(3t.

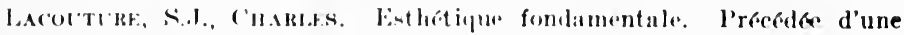

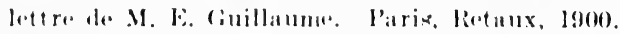

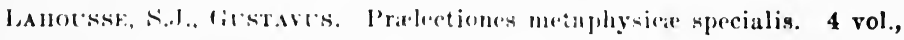
lowvain, litis. 
Lahousse, S.J., Gustavus. Prælectiones logicæ et ontologiæ. Lovanii, Peeters, 1889.

Summa philosophica ad mentem Sancti Thomæ. Lovanii, 1892.

Lamers, G. H. Thomas van Aquino. Utrecht, 1896.

Laxgen, Jos. Roger Bacon. Histor. Zeitsch., 1883.

de Lantsheere, L. Du bien au point de vue ontologique et moral. Louvain, 1886.

L'objectivité de la connaissance. Bruxelles, 1890.

LANZILLI, S.J. In Cosmologicis Quæstionibus Comparatio. Vallibus Anieii, 1861.

Lasplasas. Ensayo de una definición de la escolástica. Barcelona, 1903.

Latinus, J. Une excursion philosophique en Espagne. Rev. Néo-Scol,, 1901.

Lauer, H. Die Gewissenslehre Alberts des Grossen. Philos. Jahrb., 1904.

Launoy. De varia Aristotelis in Academia Parisiensi fortuna. Wittenberg, 1820.

LAURIE. Lectures on the Rise and Early Constitution of the Cniversities. London, 1886.

Lechère, Albert. De facultate verum assequendi secundum Balmesium. Paris, 1900.

Le mouvement catholique kantien en France a l'heure présente. Kantstudien, 1902.

La philosophie au moyen age. Arch. Gesch. Philos., 1907.

Lecoultie, E. La doctrine de Dieu d'après Aristote et saint Thomas d'Aquin. Lausanne, 1877.

Essai sur la psychologie des actions humaines d'après les systèmes d'Aristote et de saint Thomas d'Aquin. Paris, 1883.

Lecoy de la Marche, Albert. Le treizième siècle littéraire et scientifique. N. ed., Lille, Desclee, 1896.

Lefeibre, E. Logique. Louvain, 1885.

La bête et l'homme. Louvain, 1886.

LEFEve, G. Les variations de Guillaume de Champeaux et la question des universaux. Trav. et Mém. de l'Univ. de Lille, 1898.

DE LEHEx, S.J., P. E. Institutiones Logicæ ad usum prælectionum aceonmodatæ et immaculatæ deiparæ dieatæ. 13lesis, Giraud, 1860.

Lenmex, S.J., Alfoxs. Lehrbuch der Philosophie auf aristotelischscholastischer Grundlage zum Gebrauche an höheren lehranstalten und zum Selbstunterrieht. Freiburg, Herder, 1899-1906.

lenнкun, S.J., Acg. Probabilismus vindieatus. Freiburg, Herder, 1906.

lessr, O. Der Anticlaudianus: ein lat. Gedicht des 12. Jahrh. und sein Verfasser Alanus ab Insulis. Beilage z. Programm des Gymnasiums zu Seehausen i. d. Altm., 1878-82.

Ledaxi, Algustrx. Salomon et saint Thomas d'Aquin. Lyon, Vitte. 
Lesaxs, M. Leventeschrijving van Maimonides. Amsterdam, 1815.

Lemos, O.F.M., Pl.Acho Axgel. La vida orgánica en si misma y en sus manifestaciones. Madrid, Del Amo, 1902.

Lextzex, J. II. Erkennen und Glauben, mit besond. Beriieksichtigung des Anselms von Canterbury. Bonn, 184 s.

Ifo XIII. De Philosophia christiana ad mentem S. Thome Aquinatis doctoris angelici in scholis eatholicis instauranda. S. D. N. Leonis 1). P. Papa XlII epistola encyelica. Romar, 1sia); Engl. by F. Rawes, London, Burns \& Oates, 1879.

The great Encyclical Letters of Leo XIII, with Preface hy Rev. J. J. Wyune, S.J. New York, Benziger, 1903.

Lepicier, A. M. Tractatus de Deo uno. Pars l: De pertinentibus ad divinam essentinu. Paris, Lethielleux, 1902.

I.eprin, O.P., Alskro. Examen philosophico-theologicum de ontolofismo. Lovanii, Fonteyn, 1874.

Elementa philosophia christiane. Lovanii, Peeters, $1875 \mathrm{fr}$.

L'attivita voluntaria dell'uomo e l'intlusso causale di I)io. Roma, Befani, 1890.

Opuscules philosophiques (trad. franc. par E. Vignon). Paris, 1900.

I.ercukr, S.J., I. Ceher tine Form des Gottesleweises aus der sittlichen Verpflichtung. Zeitsch. f. kath. Theol., 1900.

Le Ror, Fonarb. Scholastique et Philosophie molerne. Mrmain (Iyon), 1906.

Lesserteir, F. C. Saint Thomas et la prodestination. Paris, lethielleux, 1858 .

Levgrar. J. Az amberi es az allati lelekrïl. Böles. Foly., 1892.

Az Gleteröröl. Bülcs. Foly., 1893.

Lèvay, P. Aquinas es Decart. Bülcs. Foly., 1893.

LEVY, L. (i. La metaphysique de Maimonide. Dijon, 1905.

Linekatoke, S.J., Matтro. Dialoghi filosofici. Napoli, 1840; 2. ed., 1 sisl.

Institutiones logiea at metaphysicas. Neapoli, 1840-42; Mediolani, $1 \mathrm{siti}$.

Theses ex metaphysica selecta quas suscipit propugnandas Fran(iscus Pirenzio in rollegro nenpolitano s. J. ab. divi sebastiani Quinto ldus Septembris anno MI)(CoXIJI. Neapoli, 1842.

Dialege sopra l'origine delle idee. Napoli, 1843.

11 Pantrismo transcendentale, dialogo. Napoli, 1844.

Il I'rogranos. Dialogo filosofieo di M. Lileratore. 2. edl., Genova, listi:.

Ethica et juris natura elementa. Neapoli, 184t; Romar, 1857; Ital., Romil, Istis.

Elementi di filoutia. Napoli, 1845; 2. ed., 1850; Livorno, 1852.

Institutiones philomophicare. Xeapoli, 1851; 5. ed., Romar, 1872.

Della conourenza intellettuale. Napoli, 18.5. Romat, 15.57; Germ. ly L. Franz, Mainz, latil; French by E. Sulde, Tournai, 1863. 
I. 1858.

Sopra la teoria scolastica della composizione sostanziale dei corpi. Roma, 1861.

Risposta ad una lettera anonima sopra la teoria scolastica della composizione sostanziale dei corpi. Roma, 1861.

Dell'uono. V. 1: Del composto umano. V. 2: Dell'anima umana. Roma, 1862 ff.; Span., Bareelona, 1882; French by Deshayes. Paris, Berche \& Tralin, 188.5.

La Filosofia della Divina Commedia di Dante Alighieri. (In Omaggio a bante Aligh. dei (attolici ital.) Roma, 1S65.

Spicilegio del P. M. Liberatore d. C. d. G. Napoli, 1877-7s.

Della eomposizione sostanziale dei corpi. Napoli, 187s.

L'antocrazia dell'ente. ('ommedia in tre atti. Napoli. 1880.

Degli universali. Confutazione della filosofia Rosminiana difesa da Mons. Ferre Roma, lss3-4; Span. by F. de P. Ribas y Servet, Barcelona, lss8; Engl. by E. 11. Dering. london, 1889.

Liebser, A. Ihugo von St. Fictor und die theologisehen Richtungen seiner Zeit. Leipzig. 18336.

de Liecuty, li. Albert le Grand et saint Thomas d'Aquin, on la seience au moven âtge. Paris, lisso.

Les Questions disputées. traité de l'être et de l'essence. Bar-le-Duc. 1883.

Linotke, II. Die Beweise fürs Daseins Gottes bei Anselm v. C. und Renatus Descartes. Ineidelberg. 1893.

Lilla, Vixcexzo. La mente dell'Aquinate e la filosofia moderna. Torino, 1873.

S. 'Tommaso d'Aquino filosofo in relazione con Aristotele e Platone. Napoli, 1880.

Lramolda, S.J., Max. De distinctione essentia ab existentia. Regensburg, 1883.

Die Pridestinationslehre des hl. Bonaventura. Zeit. f. liath. Theol., 1892.

Die Analogie des Seinbegriffes. Zeitsch. f. kath. Theol., 1893.

Quastionum metaphysicarum libri V. Innsbruck, 1893.

Lindsay. Scholastic and Medizeal Philosophy. Arch. Gesch. Philos., 1902.

Lipparoxi, (ireg. A philosophia eonforme a mente de s. Thomas de Aquino, exposta per A. Rosmini. Rio de Janeiro, 1880.

Lipperheide, Victor. Thomas von Aquino und die platonische ldeenlehre. Minchen, 1890.

Littie. A. (i. (irey Friars of Oxford. Oxford, 1892.

Loev. De vita R. Lulli speeimen. Hala, 1830.

LoEwe. Der Kampf zwisehen dem Realismus und Nominalismus in Mittelaltor, sein Ursprung, und sein Verlauf. Prag, 1876.

Lonextz, F. Aleuius Leben. IIalle, lse9) Engr. by .J. M. Slee, London, 1837. 
Iorexzeri, Bexferto. Philosophia theoretice institutiones secundum doetrinam Aristotolis et 2 . Thomam Aquinatis. Romed, 1890 ; u. ed.. 1sion.

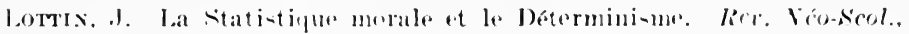
$190 \mathrm{~s}$.

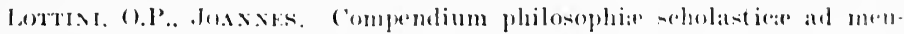
tom S. Thomar Aquinatic. Firenze, 1900.

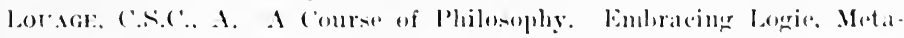

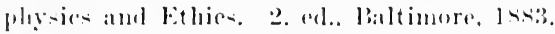

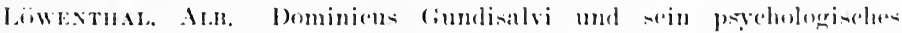

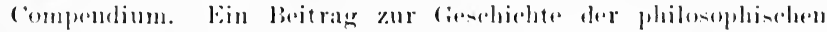

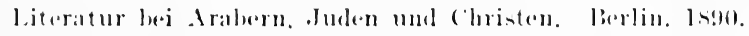

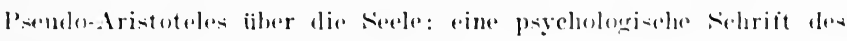

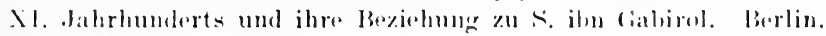
Mayer a Miiller, 1891.

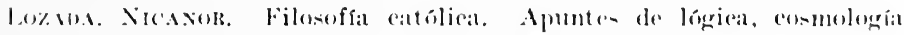
Y peieolegía, para los alummos del siminario coneiliar. Mexieo. lition.

lozaxo y lituo. T. Las armas de dialétiea, o breve intruceion parat

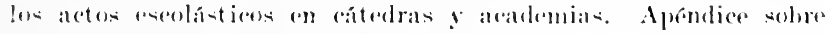
lan legen del silogi-mo. Madriel, lsild.

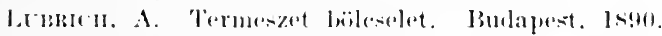

Xevelestudomány a a bïleselet. Budlapest, lis?t.

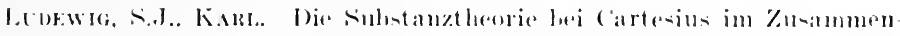
hane mit der sehelantischen n. neneren Philosephie. Fuhla, lsig:s.

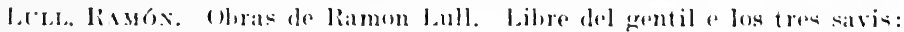
lihe de la primera esengua intenció libre de mil proverbis. festom originales publicados a ilustrados con notas y variantes

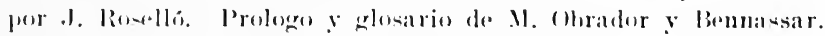
Palma de Malerear. Colomatr, lissti logol.

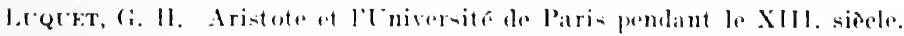
Paris, Leroux. 1904.

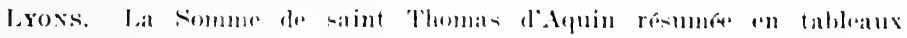
symoptipues. Niere, 1901.

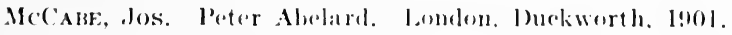

MacDoxald, Alfx. Fohution and the Futhers. The resket (Anti. goni-h), 1 s.9.5.

St. Thomas and Evolution. Foshet, lsoge.

Development not Evolution. 'ath. Horld, Isati.

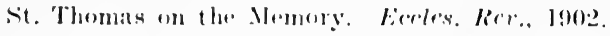

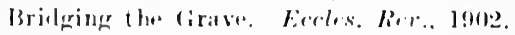

The Peychology of our spiritual conceptions. Molphin. 1905:

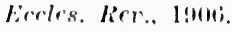

st. Thomas and the Eucharistio Sacrition. Amer. rath. Quart., 1906. 
MacDonald, Alex. St. Thomas and the Virgin Birth. Questions of the Day, Vol. 1, C. P. A. Pub. Co., New York.

The Ethical Aspect of Bribery. Questions of the Day, Vol. 2; C. P. A. Pub. Co., New York.

The Imagination. Questions of the Day, Vol. 2; C. P. A. Pub. Co., New York.

McDonald, Walter. The Conservation of Energy and the Vital Activity of Organisms. Dublin Rev., 1902.

The New Knowledge and the Old Philosophy. New York Rer., 1905.

McNabb, O.P., Vixcent. Logic and Faith. New York Rev., 1905-6.

Scholasticism and the Modern Method. Amer. Eccles. Rev., 1903.

McSorley, C.S.P., Joseph. The Christian Idea of Justice and Equality. Cath. Univ. Bull., 1898.

Hugo of Saint-Victor, Mystic. Dolphin, 1902.

Mader, D. Oratio de laudibus Thomæ Aq. Pragæ, 1870.

de Madureira, B. A. Compendio de philosophia elementar conforme ao programma official de 1895 . Coimbra, 1896.

Magevney, S.J., Eugene. Christian Edueation in the "Dark Ages." Amer. Cath. Quart., 1898.

Maner, S.J., Michafl. Psychology. New York, Benziger, 1891; 5. ed., London, Longmans, Green \& Co., 1902.

Mamonides. Perusch Ma-Mischna. German by R. I. Fürstenthal. Breslau, 1842.

Yad Hachazakah or Mischne Torah. Hebrew and Engl. by H. H. Bernard, Cambridge. 1832; Hebr. and Germ. by E. Maller, Wien, 1889 ; Germ. by E. Solowciczyk, Königsberg, 1846; Engl.. London. 1838 ; n. ed., 1863.

More nebuchim (Guide of the perplexed). Arab and French by $\mathrm{S}$. Munk, Paris, 1855-56; Hebr. and Germ. by S. Scheyer, Frankfurt, 1830-38; Germ. by R. J. Fiirstenthal, Krotoschin. 1838; ltal. by I. I. Maroni, Livorno, 1870-71; Engl. by II. Friedländer. London, 1885.

Kiddusch Hachodeseh. Vebersetzt und erlïutert v. E. Mahler. Wien, 1889.

Maisoxifive. L. In eardinal philosophe, Mgr. Mercier. Bu. I. pccl.. 1907.

Mamixi, C. Intorno al libro del Prof. ('. Passaglia intitolato " Jal dottrina di San Tommaso secondo l'encicliea di Leone Xlll. Torino, $18 \mathrm{~s} 1$.

Maxcisi, Hinoxymo Maria. Elementa philosophix ad mentem D. Thome Aquinatis ad triennium accommodata. Romx, Propagimda, 1598.

de Maxdito, S.J., PIUs. Institutiones philosophice ad normam doetrina Aristotelis et $\mathrm{S}$. Thome. Rome, 1894.

Le specie organiche secondo la dottrina di San Tommaso e la moderna teoria degli evoluzionisti. Roma, Befani, 1895. 
de Maxdato. S.J. PILs. Disaprtazioni filonofiche. Evistenza di Dio. Trosofismo moderno, Evoluzionismo. ('ause "rimedi di materialismo, Importanza della religione. Roma, 1907 .

Mavionset, O.P., l'ikere. Les idees cosmographiques d'Alhert le firand et la deouverte de l'Amérique. Rer. them., ls!3s.

Polemique averointe de Siger de Brabant rt saint Thomas. Rer. thom., 1895 9ti.

Jean Seot Erigene et Jean le Sourd. Rere them.e 1897.

siger de Brabant et l'Averroisme latin au Xlll. siecle. Fribourg. 1499.

1.e Traite "De Erroribus Philosophorum." Rer. Nenscol., 1907.

Alaxo. ('. Ie probleme de la vie ou le principe vital devint la seience et la mataphysigue. Paris, Bloud, 1900.

Le Pesimisme contemporain. Ses precursenrs, ses representanta, ses somrees. Paris, Bloud, 1902.

Mlaxser, I. A. Possibilitas pramotionis physica thomistipir in actibus liberis naturalibus juxta mentem divi Aquinatis. Friburgi (Switz.), 1895.

Maxsiox, A. L'induction chez Albert le Grand. Rer. Vén-siol., l906. of Margekir, A. Esina sur la philosophie de saint Bonaventure. Paris, 185.5.

I. principe de causalite est-il une proponition analytique on une propesition synthetique a priori? Ann. Philos. chr., lsive.

de Makia, S.J., Michari. Opuscula philosophica et theologien Sti. Thoma Alp. Editio accurate recognita et nonnullis quatstionibus Ine scholiis aucta. Tiferni Tiberini, ('itth di Castello, Iskt).

Philouphia peripatetico-scholastien. 3 vol., Ronae, Is:2.

compendium logicar et metaphysiear. Romer, ('uggiani, 1s97; ed. 2.. 1900.

Mabiaxi, A. Sian Bonaventura ... studii. Firenze, Isit.

Mariftax, J. P'robleme de la clnswification des sciences d'Aristote a saint Thomas. l'aris, 1901.

Makiotri, (. San Franereco, San Tommaso e Dante mella civilta cris. tiana. Veneria, 18s3.

Markr, D). Die natiorliche Thrologie des Rnymundus von Sabunde. Istit.

Maktan, L. Onaervazioni preliminari allo studio della filosofin tomis. tica. Piacenza, 1sk!

dakt in: Eixala, Rimóx. Gurso de Filosoffa clemental. Barcelona, 1841.

Mamual de la historia de la filosoffa. Bareelona, 1842.

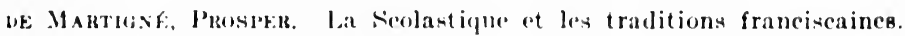
Pariq, Iathiellenux, 18st.

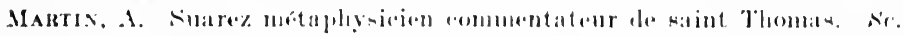
cuth., lis!s. 
Martin, P. A szépség fogalmáról. Bölcs. Holy., 1886.

Szent Tauás és Kant. Bölcs. Foly., 1887.

Martinez, Marcelino. Fray Luis de León y la filosofía española del siglo XVI. Madril, 1891.

martinez Nuñez, Zacarías. Ideas, Imágenes y Sensaciones. Ciudad de lios, 1907 .

Estudios biológicos. Madril, Saenz de Jubera, 1907 .

DE MAtTia, G. La mente di San Tommaso intorno all'origine dell'anima, sua unione col corpo ed origine delle idee. Napoli, Errico, 1900.

Matriussi, Guido. Primato della volontì. Scuola calt., 1906.

Aneora la volontà nel pensiero del Venerabile Duns Ścoto. Ścuola catt., 1906.

Maumus, O.P., V. Saint Thomas d'Aquin et la philosophie cartésienne. Paris, Lecoftre, I890.

Les Philosophes contemporains. Paris, Lecoffre, 1891.

Jes doctrines politiques de saint Thomas d'Aquin. Rer. thom., 1893.

Matri, Juax. Importaneia de la restauración de la filosofía escolástica en estos tiempos. Alieante, Seva, 1890.

Malra y Gelabert. Fl optimismo del B. Raimundo Lulio. Bareelona. 1904.

Macrexbmecher, Max. Thomas von Aquino's Stellung zum Wirthsehaftsleben seiner Zeit. Leipzig. 1898.

Macro, S.I., Symestro. Quæstiones Philosophica auctore S. Mauro S. J. presbytero, olim in Collegio Romano Philosophiæ et S. Theologize Professore, ed. novissima cum epistola a R. P. M. Liberatore prefata. Parisiis, Lecoffre, 1876.

Mausbacir, Jos. Christenthum und Weltmoral. 2 Vortriige ïber das Verhälniiss der christlichen Moral zur antiken Ethik und zur weltlichen Cultur. Münster, Aschendorff, 1897.

Der Begriff des sittlich Guten nach d. hl. Thomas von Aquino. Freilurg, 1898.

Divi Thome Aquinatis de roluntate et appetitu sensitivo doctrina. Paderborn, 1901.

Die katholische Moral, ilıre Methoden. Grundsätze und Aufgaben. Kïln, 1901.

Die Stellung des hl. Thomas von Aquin zu Maimonides in der Lehre von der Prophetie. Theol. Quart., lxxxi.

Maxwell, II. Roger Baeon. Blackwood's Mag., elvi.

Mazelda, S.J., Camiluss. De Deo C'reante. Praclectiones ScholasticoDogmatice quas in Collegrio ss. Cordis Jesu ad Woodstock maxima studiorum Domo Soe. Jesu in Foed. America Sept. Statibus habebat. Woodstoek, 1877 ; ed. 3.. Rome. 1893.

Medices, Fritz. Ein Wortführer der Neuscholastik und seine Kantkritik. liuntstudien, 1901 . 
Menrex, A. F. M. La philosophie d'Avicenne Ibn Sina, exposere d'apres des domments infits. Jouvain, lsse.

Les rapports de la philosophe d'Avicenne avec lislam. Jouvain, 1583.

Et udes our la philosophie d'Arienene conernant son rapport aver celle d'Avicenne et Gazali. Louvain, lisss.

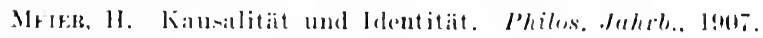

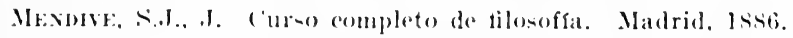

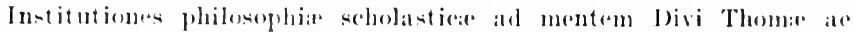
Suarezii. Valli-oleti, Cuestal, lsstg st.

Lat religion catoliea vindicada de las imposturas racionalietas feon un prólogo de 1). .I. M. Orti y Lara). Madril, lssis.

Mracenar. Del veru, del buono a del bello. Nipoli, 1sa9.

Mexzel. Doctrina J. Sooti Erigrna rum christianat comparata. liautzen, lstio.

Mracon, M. Cotrum in dialectica aristoteliea recte distingnantur tigura modique syllogiomi. Froiburg-i.s., imp. S. Patul, 1 s9.9.

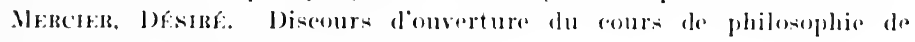
salint Thomas. Louvain. lsise.

Le determinismo mecanique et le libre arhitre. Louvain, Jsst.

fommate du cours de philosophie selon saint Thomas d'Aquin,

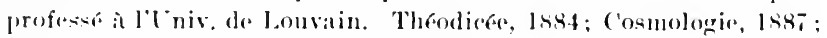

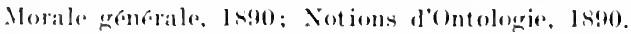

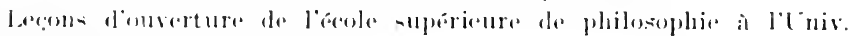
de Lomvain. Lille. 1s90.

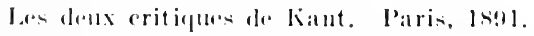

lapport sur les atules superieures de philosophie. lombain, 1s9l; cipan. lima, imp. de " lal (Obrero," 1902.

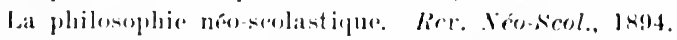

Les origines de la pardologie contemporaine. Louvain, 1897; Polish by W: Komiakiewioga, Warszawa, 1900; Npan. Wy Arnaz, Madrid. Silenz de Julera. l901; Ital. by A. Messina, Roma, Desclee, 1903.

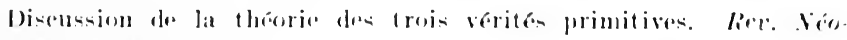
sieol., $1 \rightarrow ! 4$.

Ja définition philosophigue de la vie. 2. ed.e louvain, lsas.

La peychologie de Deurartes et lanthropologie seolastique. life.

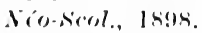

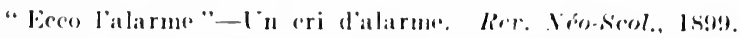

C'riteriologe generale on traito general de la rertitude. Louvain, 1899: 5. ad., 1906; Jolish by W. Koniatiewieza and A. Krasnowolskiego, Warszawa, lg01; lortug. by Dantas Pereira, Vizeu, 1904.

La notion de la verite. Jemuan, J!000.

La percholugie experimentale ot la philosophio spiritualiate. Lou vain, 1990; Engl. hy k. .l. Wirth, New York. Brngiger, 1902. 
Mercier, Desirf. La pensée et la loi de la eonservation de l'énergie. Louvain, 1900.

Le bilan philosophique du X1X. siecle. Louvain, 1900.

Merten, J. Ueber die Bedeutung der Erkenntnisslehre des hl. Augustinus und des hl. Thomas von Aquino für den gesehiehtlichen Entwicklungsgang der Philosophie als reiner Vernunftwissensehaft. Trier, 1865.

Meufrels, Hubert. A propos d'un mot nouveau. Quinzaine, 1901.

Un probleme a resoudre: dans quelle langue doit être donné l'enseignement de la philosophie dans les séminaires. Rer. NéoScol., 1902.

Meurin, S.J., Leo. Ethics. Port-Iouis, 1891.

Meyer, S.J., Theon. Institutiones juris naturalis seu philosophix moralis seeundum principia $\mathrm{S}$. Thom:e Aquinatis. Friburgi, Herder, $1885 \mathrm{ff}$.

Meynell, Charles. Padre Liberatore and the Ontologists. London, 1868 .

MEzArd, O.P., P. Medulla S. Thomæ Aquinatis seu meditationes ex operibus S. Thomæ depromptæ. Paris, Lethielleux, 1907.

Mezzera, Gius. Risposta al libro del G. M. Cornoldi "Il Rosminianismo." Milano, 1883.

Michael, S.J., E. Albert der Grosse. Zeitsch. f. kath. Thcol., 1901.

Geschiehte des deutsehen Volkes vom 13. Jahrh. bis zum Ausgange des Mittelalters. Freiburg, Herder, $1903 \mathrm{ff}$.

Michaud. Guillaume de Champeaux. Paris, 1867 .

Michel, Axton. Die Kosmologie des Mos. Maimonides und des Thomas von Aquino in ihren gegenseitigen Beziehungen. Philos. Jahrb., 1891-92.

Michelis, Fried. Bemerkungen zu der von J. Kleutgen vertheidigten Philosophie der Vorzeit. Freiburg, Herder, 1861.

Michelitsci. A. Atomismus, Hylemorphismus und Naturwissenschaft. Graz, 1897.

Mieile, P. De substantiæ corporalis vi et ratione secundum Aristotelis doctorumque scholasticorum sententiam. Iingonis, 1894.

la Matière première et l'étendue. Fribourg. 1898.

Les postulats de lidéalisme et la théorie de la connaissance. Pensée contemp., 1907 .

Migne. Patrologia latina. 221 vol. in-4o, Paris, 1844-55.

Mugxox, A. Les origines de la scolastique et Hugues de Saint-Victor. Paris, Lethielleux, 1895.

Minúlkovics, L. Ismerettani elïadások. Bölcs. Foly., 1893.

Minálovits, F. Plátó theologiája. Böles. Foly., 1893.

Az indukeió határai. Bölcs. Foly., 1898.

Min Ĺyfy, A. Az államhatalom eredete. Bölcs. Foly., 1898.

Milier. J. Bifecker. Jeo XIII and Modern Civilization. New York, Fissdale Press, 1897. 
Minlox, F. La clef de la Philosophie seolastique. Etude sur la com. position substantielle des corps dayres saint Thomas d'Aquin. Paris, Delhomme \& Briguet, 1897.

Mrg, S.J., Jowx.J. Modern and Ancient Philosophy compared. Amer. ('ath. Quart., 1879.

Pretended Inity of Modern Philosophy. Amer. Cath. Qwart., 1880. The Existence of God Demonstrated. Amer. C'ath. Quart., 1881-82. On the Nature of the Human Soul. Amer. C'ath. Quart., 1854.

Science and Spreculative Philosophy. Amer. Cath. Quart., Issi.

The Idea of Evolution. Amer. Cath. Quart., 1803.

Criticism on Recent Pantheistic Evolution. Amer. Cath. Quart., 1894.

The Datal of Molern Ethies Examined. 3d ed., New York, Benziger, 1894.

Modern Theories of Society. The knd of Society. Amer. Cath. Quart., 1896.

Determinism versus Free-Will. Amer. ('ath. Quart., 1902.

Mixges, O.F.M., Parthexil's. Ist Duns Ścotus Indeterminist? (Ihitriige.) Muinster, 1905.

Bedeutung von (Ohjekt, Lmstiinden und Zweck fïr die Sittlichkeit eines Aktes nach Duns Scotus. Philos. Jahrb., 1906).

Die Gnadenlehre des Duns Scotus auf ihren angeblichen Pelagian. ismus und Semipelagianismus geprïft. Miinster, 1906.

Der Gottesbegriff des Duns Scotus auf seinen angeblich excessiven Indeterminismus gepriift. Wien, 1906.

Beitrag zur lehre des Duns Scotus iiber de Enivokation des Sein. begriffes. Philos. Jahrb., 1907.

Mistegliaga, S.l., V. M. la Moral indegendiente y los principios del derecho muevo. 3. ad., Madrid, Inel Amo, 1906.

Mrola, A. Codien MSt. opermu St. Thome de Aquino ot $\mathrm{S}$. Bonaventurar in Regia Neapolitam Bibliothen, Neapel, 1sit.

Mek, Mister. Armonfa entre la ciencia y la fe. N. col., Matrid, Is92.

Meraldes y Suekt, Josfe. Sunto Tomas de Aquino y el moderno regimen contiturional. (on un prólege de 1). J. M. Orte y Larn. Mndrid, 1 sis().

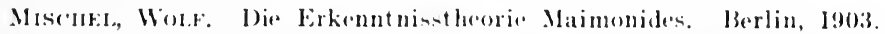

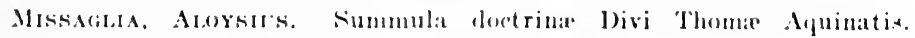
Milnno, 1s!19; 2. ed., Roma, Desclée. 1900.

Mogila, Agost. I Suareziani e l'Alate losmini. Pianenza, Iskis.

La filonotia di San lommano d'Alunino nelle senole italiane. Pia ("nzat, 1sisis.

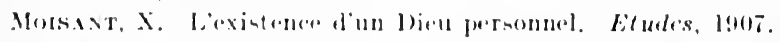

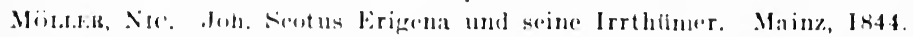

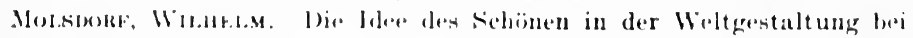
Thomas vou Apuino, Jent, lsigl. 
Moxvier, Fraxis. De Gottescalci et Joh. Scoti Erigenæ controversia. Paris, 1852.

Alcuin et son influence littéraire, religieuse et politique chez les Franes. Paris, 1853.

Monvier, M. La théorie de la pluralité des formes et la chimie moderne. Etudes francisc., 1901.

Montagrani. Un eminente scolastico troppo dimenticato (1)ionisio Certosino). Montreuil-s-Mer, 1898.

Rosmini, San Tommaso e la Logica. Bologna, 1890.

Tomisti e Neotomisti. Lettere filosofiche. Roma, Befani, 1891.

Scolastica ed estetica. Parma, Fiaccadori, 1891.

Montagne, O.P., A. Saint Thomas d'Aquin à Toulouse. Rev. thom., 1894.

La pensée de saint Thomas sur les formes de gouvernement. Rev. thom., 1900-1.

ne Montalembert, C. F. Saint Ansclme. Paris, 1844.

Monter, Leon. Mémoire sur saint Thomas d'Aquin. Paris, 1847.

De Principiis quibus eonstat Thome Aquinatis Ethica commendatio. Parisiis, 1848.

Moosherr. K. Die Versöhnungslehre des Anselm von Canterbury und Thomas von Aquino. Jahrb. f. prot. Theol., 1890.

DE LA Mora, Migues M. El hombre no pertenece al género animal. Guadalajara, 1904.

vox Mongott, Fraxz P. Die Theorie der Gefühle im Systeme des hl. Thomas. Eichstadt, 1864.

Morix, F. De l'histoire de la philosophic scolastique. Lyon, 1852.

Dictionnaire de philosophie et de théologie scolastique. 2 rol., P'aris, $1857-58$.

Morminas, Humpiney. First P'rineiples of Mental Devolopment. Rev. ('ath. Pedag., 1903.

Mrckermax, s.J., H. Instinetive and lntelligent Activity. Ifessenger, 1905.

Mïller, Aloysics. /m Analysis des Raumes. Philos. Jahrb., 1903.

Mïnes, I. Biographisches iiber Duns Scotus. Köln, 1881.

Mirm.k. A.J., .J. Der Gottesbeweis aus der Bewegung. Zeitsch. f. kath. Theol., 1897.

Mülukr. St. Thomas und die moderne Wisisenschaft. Beiträge zum allgemeinen \%eitung. Miinchen, 1s!4.

Mexglí, ('. DE J. Del Culto considerado en sí mismo y en sus relaciones con el individuo, la sociedad y el gobierno. Morelia, 1847.

Del Dereeho natural en sus principios commes y en sus diversas ramificariones. 4 vol., Mexico, 1849.

Obras diversas del liceneiado ('. de .J. Munguía. Morelia, 18.̃2.

Los Principios de la Iglesia eatolica comparados con los de las escuelas racionalistas. Méxieo, 1878. 
Mexk, Shomos. Mélanges de philomophie juive et arale. Paris, 1859.

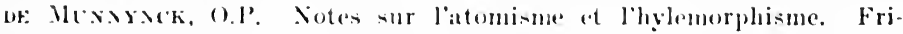
bourg, 1s!ss.

La conservation de l'energie et la liberte morale. Rere thom., 1899 ; Paris, Bloul, 1901.

Enecere la conservation de l'energie. Ret. thom. 1s9?.

Lat prómotion physique selon l'écol" dominicane. Re'te Véoscol., 1901 .

Prielectiones de Dei existentia. louvain, 1904.

Mixz, Isak. Die Religion-philosoplie des Maimonides und ihr Fin flu-s. Berlin, Ixki.

Mrrack, . Q. Questions d'ontologie: etmdes sur saint Thomas. Lyon. 1876.

Mrutes, (i. Scotus Erigena. Halle, 1843.

Sinneo, P. 11 pensiero filosotico mederno e il rinnosimento della filo. sotiat tomistica. Napoli, 1901.

NaciY, Amso. Die philosophischen Ahhandlungen des Jatpub ben lshaq al-Kindi (Beitrïge). Miinster, 18!) .

ne: Narn, Pintro. Antonio Rosmini ad i (iesuiti dinanzi a san Tommaso d'Apuino. Torino, 1sis.

I muri Tomisti a la storia dellat filosotial. Rit. ital. di filos.. Is?o.

Tommaso d'dyuino e leeta in eni s'avemue. Forli, Mariani, lsas.

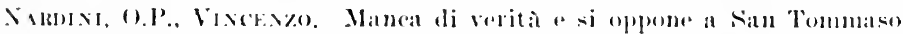
las soluzione di un alto problema metalisieo abbracediata dal l'rof. P. M. Lilweratore d. ('. d. (i. Gindizio del P. V. Nardini Domenirance. Romna, latiz.

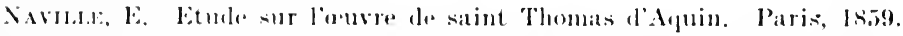

Seavers, I. 1. W. Der hl. Bithard und sein \%eitalter. Berlin, ls30; French ly T. Vial, Paris, lsiz: Engl. by M. Wrench, London. 1843.

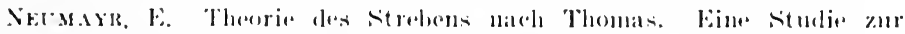

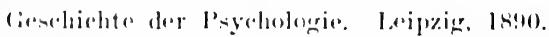

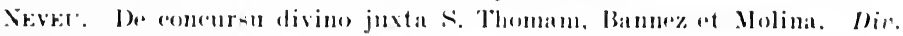
Thom., 1902.

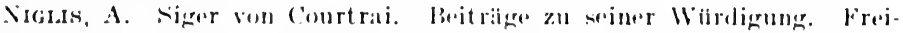
burg-i-13., ('haritas-1)ruckerei, lacos.

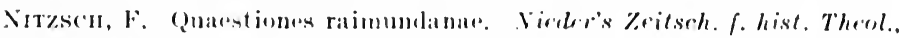
18.59 .

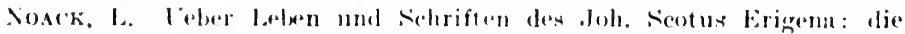

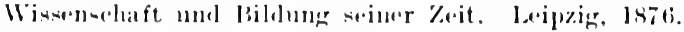

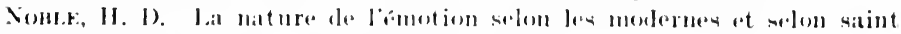

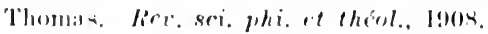

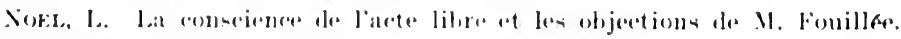

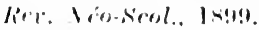

lat (an-rience du libre arbitre. Iouvain, Isog).

la determinisme. Louvain, 1905. 
Noless, W. H. De Leer van den h. Thomas van Aquino over het recht. Utrecht, Beijers, 1890.

Noriega, Rafael. La Escolástica y el pensamiento moderno. El Pais (Mexico), 1903.

von Nostitz-Rieneck, S.J., Robert. Leibniz und die Scholastik. Philos. Jahrb., 1894.

Notter, A. Kant antinomia-tana és a kereszteny iskola bölcselet. Bölcs. Foly., 1890.

Nowent, W. G. St. Anselm. Christ. Exam., lxxiii.

Nys, D. Le problème cosmologique. Louvain, 1888.

La notion du temps d'apres les principes de saint Thomas d'Aquin. Louvain, 1898.

La nature du composé chimique. Louvain, 1899.

La notion despace au point de vue cosmologique et psychologique. Louvain, 1901.

La definition de la masse. Louvain, 1901.

La divisibilite des formes essentielles. Rev. Téo-Scol., 1902.

Cosmologie ou etude philosophique du monde inorganique. Louvain, $1903 ; 2$. ed., 1906.

O'Brien, Convelies. Philosophy of the Bible Vindicated. Charlottetown, 1876.

Оснава, J. A lélekszellemiségévöl. Bölcs. Foly., 1897.

Ellenvetések a lélek halhatatlansága. Bölcs. Foly., 1900.

A lélek eredetéröl. Bölcs. Foly., 1902.

De Officiis hominis generatim, tractatus ex Summa Philosophica Fr. S. M. Roselli desumptus. Guadalaxaræ, 1851.

Oischinger, J. N. C. Quæstiones controversa de philosophia scholastica. Landshut, 1859.

O'Kane, O.P., M. St. Thomas and the Beautiful in Art. Rosary Mag.. 1897.

The Conservation of Energy and Voluntary Activity. Amer. Cath. Quart., 1903.

O'Leary, Cornelil's M. Decline of the Study of Metaphysics. Cath. World, 1880.

Olivieri, SEb. Tractatus de ideologia ex operibus Divi Thome Aquinat is depromptus. Gienux, 1890.

O'MAinoxy, T. Az apriorikus összetevï itéletekröl. Bölcs. Foly., 1889. O'Mninoxy, T. J. Summa Summæ, sc. Summa Theologice D. Thoma Aq. Analytico-Synthetica Synopsis. In usum scholarum cleriealium ad mentem D. Thoma in questionibus occurrentibus, presertim philosophicis, certius eitiusque aperiendam, necnon ipsius Summa et gratiorem et utiliorem reddendam. Dublinii, 187\%.

Ortí y LaRa, J. M. Krause y sus discipulos convictos de pinteismo. Madrid, 1864.

Lecciones sobre el sistema de filosofía panteistiea de Krause. Madrid. Tejada, 1865. 
Ortí Y LARA, J. II. La Ciencia y la Divina Revelación ó demonstración de que "ntre las ciencias y los dogmas de la religión católica no pueden existir contlictos. Madrid, 1881.

Logica. Novisima edieión, Madrid, 1885.

lecciones sumarias de metafisica y filosofia natural segran la mente del Angélico Doctor Santo 'Tomás de Apuino. Madrid, 1887.

Cartas de un filósofo integrista al director de La C'nión Católiea. Madrid. Issig.

Principios de Psicología sagnin la doctrina de santo Tomás de Aquino, mirando el estado actual de la cultura molerna. Madrid, 1890 .

los grandes arenues del liniverso o filosofía de la naturaleza. Madrid, 1890.

Curso abreviado de metafísica y tilostfa natural. 2. ed.. Matdrid, imp. S. Franciseo de Sales, lsas tr.

Ortiz, S..J., Luis. La Vida. Bogotá. 1s93.

Ostikr. H. Die Psychologie des Hugo von St. Viktor. Ein Beit rag zur (ieschichte der Psychologie in der Friihscholastik (Beitriig(e). Minstor, 1906 .

Ortex, A. Allgemeine Erkenntnisolelire des hl. Thomas. Paderborn, 1882.

Das Reich des (ieistes und des Stoffes. Paderborn, Schöningh, 1900.

Ozaxam. A. F. Dante et la philosophie catholique an Xlll. siecle. Paris, 1839: 6. ed., 1872; Engl. ly Boissard, Lomden, 1854: hy L. D. Pychowska, New York, 1 1 ist.

Pack, EDWari A. The Growth and spirit of Modern Psychology. Amer. ('ath. Quart.. 1si!l.

The Rolation of Experimental Probhology. Amer. ('ath. Quat., 1895.

St. Themas and Modern Thomenht. ('ath. Init. Bull. Is!ti.

The Sonl in the system of st. Themuns. ('ath. Cnir. Bull.. lsas.

The World-eppy, aceording to St. Thomas. Cath. Tnir. Bull, lsas.

The concept of Immortality in the Philesophy of st. Thomas.

C'ath. Cnit. Bull., 1900.

The Argument of St. Thomats for Immertality. C'oth. Inir. Bull., 1900.

The Study of Philosophy. ('ath. I nir. Bull., 1901.

St. Thomas' Theory of Ehlucation. F'uth. Fnir. Bull., 1902.

The Psychology of st. Thomus. Manhattan Quart.. lagt.

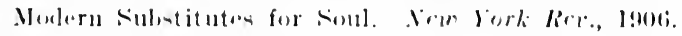

Introspetion and lexpriment. C'ath. Inir. Bull., 1907.

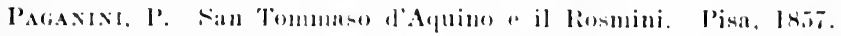

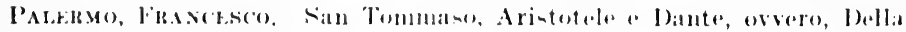

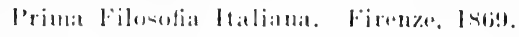


Pallex, Coxpe B. Seepticism and its Relations to Modern Thought. Cath. World, 1883.

God and Agnosticism. Amer. Cath. Quart., I886.

Palmer, M. Aristoteles és a logikai formalizmus. Böles. Foly., 1886.

Palmieri, S.J., Dominicus. Institutiones Philosophice; 3 rol., Romæe, $1874-76$.

Animadversiones in recens opus De Mente Concilii Viennensis. Romx, 1878.

Papagxi, O.P., T. La mente di San Tommaso intorno alla mozione divina nelle ereature e le questioni che vi hanno rapporto. Bencvento, D'Alessandro, 1902.

Paquer, L. A. Rosmini et son système. Canada français (Québec). 1888.

Disputationes theologiex seu Commentaria in Summam Theologicam 1). Thomæ. 6 vol., Québee, Demers, 1893-1903; 2. ed., Rome, Pustet, $1907 \mathrm{fl}$.

PAroccin, L. M. Del lume dell'intelletto secondo la dottrina dei SS. dottori Agostino e Bonaventura. Torino, 1881.

Pansons, R. Abelard. Amer. C'ath. Quart., 1889.

DE Pascal, G. Philosophie morale et sociale. Paris, Lethiellemx. $1894-96$.

De Pascal, Vixcext. Saint Thomas et le R. P. Bottalla. Poitiers, 1878 .

Passaglia, Cario. Della dottrina di San Tommaso secondo l'eneicliea di Leone XllI. Torino, 1880 .

Paste, Rom. Il " De Anima" di Aristotele commentato da Sin Tommaso. scuola catt., 1904-6.

Patiss, S.J., Georg. Das A B C der Scholastik. Wien, 1866.

Paussex, Friedricit. Das jüngste ketzergericht iiber die moderne Philosophie. Dentsehe Rundschau, 1898.

Katholicismus und Wissenschaft. Deutsche stimmen, Is99.

Kant, der Philosoph des Protestantismus. Kuntstudien, 1899.

Philosophia militans; gegen Klerikalismus und Naturalismus. Berlin, 1901 .

Pazmíny, Petri. Opera omnia partim e codd, mss. partim ex editionibus antiquioribus edita per Senatum academic. rey. seient. univorsitatis Budapestin, reeensionem accurante Collecrio Professorum Theolog. in ead. univ. Budiupestini, $1894 \mathrm{fl}$.

Pecci, (insespes. Parafrasi e diehiarazione dellopusculo di San Tommaso "De ante et exsentia." Roma, 1882.

La Predeternination physique et la seience moyenne. Traduit de litalien, avee approbation de l'auteur par l'abbe F. Deshayes. Proface par Mgr. Salué; Le Mans, 188.); German by J. Triller, Paderborn, Is8s.

Pecci, Joschim. ('f. Leo Xlll. 


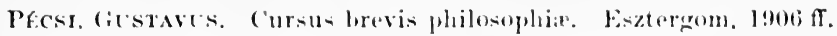

Crisis axiomatum moderna Phisicas. Fistergom, lons.

vox P'kez, Arkx. Scholantik in der (iegenwart. Berlin, 1900.

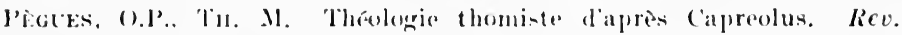
thom., 1900 .

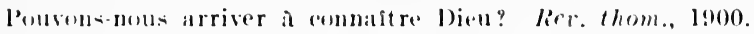

commentaire francatis litteral de la somme Theolengigue de saint Thomas d'Aquin. Toulouse, 1906.

Pentalde, E. Theorie des conepts; existence, origine, valeur. Paris, Lethiollenx, 1895 .

РКк.і́, К. A tilozófia tïrténete. Buclapest, l!no3.

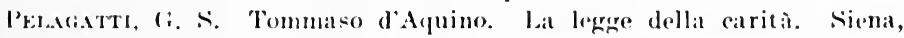
s. Bermardino.

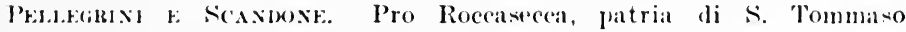
d'Alfuino (eon documenti). Napoli, d'Auria, 1903.

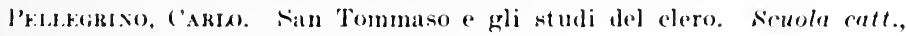
1904 .

P'rizkr, .1. L'Institut superieur de philosophie a l'lniversité catholique de Louvain; 1904.

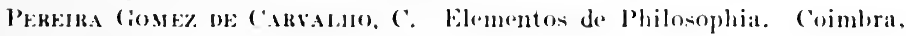
1894.

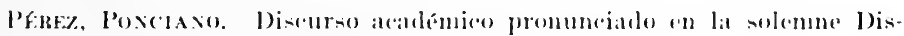
tribución de l'remios la noche del 20 de lgosto de lsiso; y una

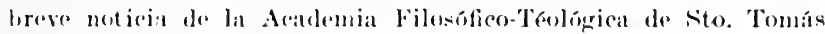
de Apuine. Iarin, 1880 .

Pkktes, I. Die in einer Mïnehener Handsehrift anfgefundene erste lateininche lebersetzung des maimonidicehen Fiihrers. Breslatu, 1875.

Pвйло, Niнто Aroxso. Lexieon philosophico-theologicum in quo scholasticorum vocabula, lecutiones, termini, distinctiones, effata et aximuata, declarantur at explicantur; ex optimis quar huensque? prodierunt litteraliter eompilatum quamplurimisque vocibus et alnetationihus anctum. Matriti, lsst.

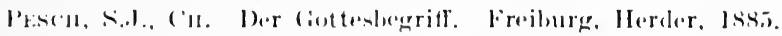

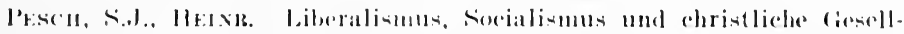

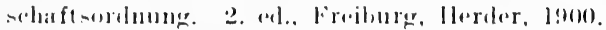

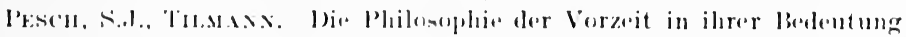
fiir dire \%ukunft. 1sit.

Dire scholantioche Bildung-methorle. Inis.

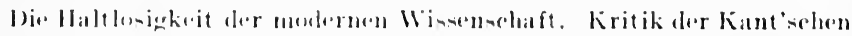
Vormunft-kritik. Freiburg, 187.

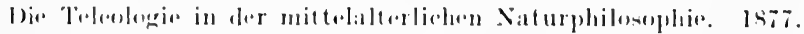

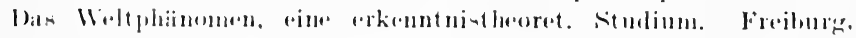
lisil.

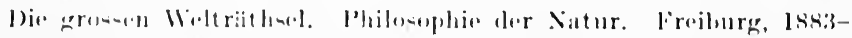

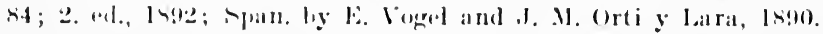


Pescir, S.J., Trlmany. Christliche Lebensphilosophie. Gedanken über religiöse Wahrheiten. Weiteren Kreisen dargeboten. 5. ed., Freiburg. Herder, 1900; French by Biron, Paris, Lethielleux, 1901. Institutiones philosophia naturalis secundum principia S. Thomæ Aquinatis. Friburgi. Herder, 1880: 2. ed.. 1897.

Institutiones logicales secundum principia S. Thomæ Aquinatis. Friburgi, Herder, 1888-90.

Institutiones psychologicæ secundum principia S. Thomæ Aquinatia. Friburgi, IIerder, 1896-98.

Seele und Leib als zwei Bestandtheile der einen Menschenaubstanz. Fulda, 1901.

Le Kantisme et ses erreurs. Traduit de l'allemand. Paris, Lethielleux, 1897.

Petri, Girseppe. Intorno al sistema filosofico del P. Matteo Liberatore della C. di G. Tucca, 1861 .

Antonio Rosmini e i Neo-Seolastici. Torino. 1878.

Sullodierno conflitto tra i Rosminiani e i Tomisti. Torino, 1879.

Sulle dottrine ideologiche del P. G. M. Cornoldi d. C. d. G. e sulle accuse d'ontologismo e panteismo contro la teosofia di A. Rosmini osservazioni. Lucea, 1883.

Petronio. In Summam catholicr fidei contra Gentiles elucidationes. Neapoli, 1886.

PETz, Fr. Philosophische Erörterungen ïher dic Unsterblichkeit der mensehliehen Seele. Mainz, 1879.

Pfeifer. Fraxcis Xavier. Die Kontroverse iiber das Beharren der Elemente in der Verbindungen von Aristoteles bis zur Gegenwart. Programu, Dillingen, 1879.

Albertus der Grosse, Eine Biographie-Festschrift. Donauwörth, 1881 .

Harmonische Beziehung zwischen Scholastik und moderuer Naturwissenschaft mit besonderer Rïcksicht auf Albertus Magnus. St. Thomas von Aquin und die Worte der Euzyklika Aeterni Patris. Augsburg, 1881.

Die Lehre von der Seele als Wesensform, betrachtet vom Gesichtspunkte der Kunst und Aesthetik. Jahrb. Ph. sp. Th., 1888-9.

Ein Argument des hl. Thomas fuir die Einheit der Seele im Menschen, beleuchtet durch Tatsachen der Pnysik, Psychologic und Mystik. Jahrb. Ph. sp. Th., 1889.

Analogien zwischen Naturerkenntnis und Gotteserkenntnis, den Beweisen für das Dasein Gottes und naturwissenschaftlicher Beweisfülırung mit Bezugnahme auf Kants Kritik der Gottesbeweise. Philos. Jahrb., 1890-91.

Psychologische Lehren der Scholastik bestaitigt und beleuchtet durch Thatsachen der katholisch-religiösen Mystik. Jahrb. Ph. sp. Th., 1891. 
Prefrer, Fascis Xavir. Widerstreiten die Wunder den Naturge-

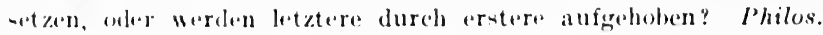
Jahrb., 1 s!93-94.

Cber den Ie"gritl der " Auslïsung" und dessen Anwendbarkeit auf

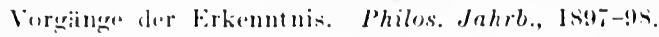

lower einen bersuch, die darwinische selektionstheorie auf die Erkenntuitheorie und den Wahrheitsbegriff enzuwenden. Fatur. und ("lio nbarung, lsis.

Moderner Pantheismus und seine Widerlegung durch ein Wunder der Niuzit. Theol, prakt. Monatschrift, 1900.

Kritiche buleuchtung der fragmente von J. Tyndall ibler chelet und II under. Theol. prakt. Monatschrift, 1900.

fibt is in Menschen mbewusiste psychische Vorginge? Philos. Juhb., 1901 .

Phuatite. Siant Thomas et la définition aristotelicienne. Sce cath., Ists.

Les Philosophes du moyen age (Textes et etudes). (ollection publiee par l'Institut superieur de Philosophie de l'lniversite de Lou vain. ('f. De Wulf.

Philosophia Jacen-is sive Institutionm Philosophiar Seholastien edita a Presbeteris societatis Jesu in Collegio quondam B. Maria ad Lacum disciplinas philosophicas professis. Friburgi Bringoviae. Herder. ('f. Hontheim, Meyer, Peseh.

The Plyyiologieal Prychology of St. Thomas. Dublin Rer., lise.

Piat. ('ionus. L.Intellect actif ou le role de lactivite mentale dans la formation des idlees. Paris, Leroux, Is91.

la liberté. Histeriqu du problème an XIX. siècle. Paris, Lethielleux, 189495.

L'ldee. Paris, Poussielgue, 1895.

La Personne humaine. Paris, Alean, 1897.

Destiné de l'homme. Paris, Alean, lsas.

La Morale chretienne et la moralite en France. Paris, 1905.

De l'Intuition en Theodicere. Rer. Véosicol., 1908.

Picavet, Fraveors. De loorigine de la scolastipue en France et en Allomagne. Paris, Leroux, lisis.

L'histoire dew rapporte de la theologie at de la philosophie. Paris, ('olill, IKsis.

Ia monvement neorthomiste. Rer, l'hilos., 1892.

lat scolastique. Jaris, colin, lsing.

La science expérimentale nu XIII. siecle. Paris, Bouillon, 1894.

Galilese dentructeur de la solustigue, fontateur de la seienee et de lat philosophie mesterne. P'aris, fontemoing, 1895.

les travaux renente sur lo now-thomisme et la seolastique. Rev. l'hiles., Ingti.

Aléard at Alevambe de Hales, créateurs de la methode scolnstique. l'aris. Leroux, lastis. 
Picavet, Fraxcois. Roscelin, philosophe et théologien. Imp. nationale, 1896.

Les discussions sur la liberté au temps de Gottschalk, de Raban Maur, d'Hincmar et de Jean Scot. Paris, Picard, 1896.

La renaissance des études scolastiques. Rer. bleue, 1896.

Gerbert, un pape philosophe d'après l'histoire et d'après la légende. Paris, Leroux, 1897 .

Entre camarades. Paris, 1901.

La valeur de la scolastique (In Bibl. du Cong. Intern. de Philos., t. 4). Paris, 1902.

Travaux d'ensemble sur la scolastique et le néo-thomisme. Rev. Philos., 1902.

Esquisse d'une histoire générale et comparée des philosophies médiévales. Paris, Alcan, 1905; 2. ed., 1907.

Deux directions de la théologie catholique au XIII. siècle. Saint Thomas d'Aquin et Roger Bacon. Kev. de l'hist. des religions, 1905 .

L'enseignement de l'Histoire générale et comparée des philosophies du moyen âge. Paris, Lib. gen. de Droit, 1906.

Nos vieux maitres, Pierre de Maricourt, le Picard, et son influence sur Roger Bacon. Rev. i. ens., 1907.

Piccirelli, S.J., J. M. De Deo Disputationes Metaphysicx. Lut. Paris, Lecoffre, 1885.

Disquisitio metaphysico-theologica, critica de distinctione actuatam inter essentiam existentiamque creati entis intercendente, ac præcipue de mente Angelici Doctoris circa eamdem quæstionem. Paris, Lecoffre, 1906.

Picherit, L. Le R. P. Carbonelle et l'Eneyclique Eterni Patris. Angers, 1883.

Pidal y Mox, Alejandro. Sistemas filosóficos. Madrid, 1873.

Santo Tomás de Aquino, su vida, historia de sus reliquias, sus obras. su doctrina, sus discípulos, sus impugnadores, el siglo X111, la Orden de Santo Domingo, etc. Madrid, 1875.

Discursos leídos ante la Real Academia de las ciencias morales. Madrid, 1887.

Pierson, Allardo. Disquisitio historico-dogmatica de realismo et nominalismo quatenus vim habuerint in precipuis placitis theologia scholastica, inde ab Anselmo usque ad Gulielmum ab Occamo. Trajecti ad Rhenum, 1854.

Pietropaoto, F. Lanima nel mondo greco e romano, nel medio evo e nella filosofia moderna. Roma, Capaccini, 1898.

Pignatako, S.J., Finice. De Deo Creatore. Commentarius in 1. P. Summar Theologicie s. Thoma. Romae, 1894.

Pinlet, A. De $\&$. Thoma onnium scholarum ehristianarum patrono. Rer. se. erel., 1899 .

Plassmaxi, Il. E. Die Sehule des hl. Thomas von Aquino. Soest, $1857-62$. 
Plassmax, H. E. Die lahre des hl. Thomats von Aquino ziber die Bescheidenledit und Demuth. Paderborn, lsis.

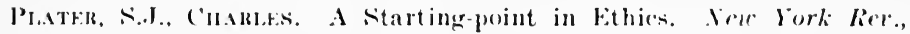
1907.

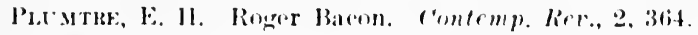

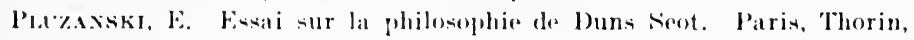
lsist; Ital. ly. A. Alfani, Firmze. 1s92.

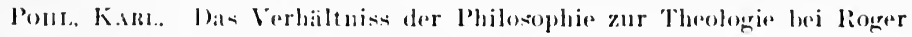
liacon. Nematrelit\%, 1893.

Pontes, Jos. Cohre die actualde Bestimmtheit des unendlich Kleinen. lhilos. Jahrb., 1893.

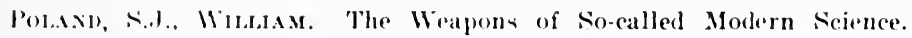
Aller. 'ath. Quart., Issis.

Triple Order of Sicience, Physics, Metaphysies and laith. Amer. 'ath. Quart., 1889.

Fundamental Ethics. An ethical analysis, conducted by way of question and answer for use in classes of Moral Philosophy. Boston, Silver Burdett, 1894.

laws of Thought or Formal logic. New York and Boston, Silver Burdett, 1894.

Rational Philosophy. The Truth of Thought or Material Logic. A Short Treatise on the Initial Philosophy, the Groundwork Necessary for the consistent l'ursuit of Knowledge. New York, Silver burdett, 1890 .

Modern Materialism and its Methods in Psyehology. Amer. Eccles. lier., Is?t.

Poloxisi, (akso. Areorlo delle dottrine dellabate Rosmini con quelle di San Tommaso dimostrato. Parabiago, 1879.

Poole. Illust rations of the History of Medieval Thought. London, 1854.

Pope I

Pontmax. A. Die systematik in den (Guastiones disputata des hl.

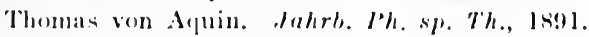

Das System der theolegischen Summa des h. Thomas von Apuin, oder iblersichtlicher und zonammenhingender Abriss der summu therel. mit Ammerkungen und Erklärungen der termini technici. Lucern, 1s!1; 2. ed., 19903.

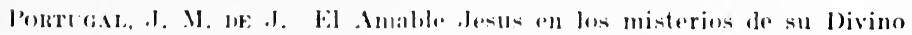

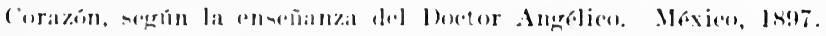

lal Santal foluntad de lios. llomenaje de adoracion, amor y pratitud al bivino landentor de los llombres al terminar al siglo XIX. Malrid, l!mol.

leinerario de la lierra al cielo. liarelena, Subirana. 1906.

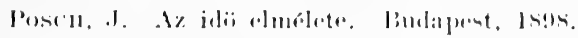

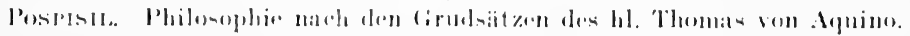
145.5. 
Potters, P. Compendium philosophire moralis seu ethice secundum principia S. Thomæ ad usum scholarum. Bredx, 1892.

Fovcuet, F. A. Ilistoire des sciences naturelles au moyen âge ou Albert le Grand et son époque considérés comme point de départ de l'éeole expérimentale. Paris, 1853.

de Polifiquet, Fr. A. Le point central de la controverse sur la distinction de l'essence et de l'existence. Rev. Néo-Ścol., 1906.

Power, S.J., M. A. The So-called Problem of Evil. A Protest. Amer. Cath. Quart., 1889.

del Prado, O.P., N. De Veritate fundamentali philosophiæe christiana. Friburgi Helvet., 1899.

Characteres essentiales physica premotionis juxta doctrinam Divi Thomæ. Jahrb. Ph. sp. Th., 1901.

De diversis perfectionis gradibus in physica primotione. Jahrb. Ph. sp. Th., 1901-2.

Concordia liberi arbitrii cum divina motione juxta doctrinam D. Thom et S. Augustini. Dic. Thom., 1902.

De Gratia et libero arbitrio. Friburgi, lib. St. Paul, 1907.

Praxte, Kari. Der Universalienstreit im 13. und 14. Jahrhundert. Sitzber. Acad. Wiss. M Ïnchen, phil. C'l., 1864.

Gesehichte der Logik im Abendlande. Leipzig, 18.55-70.

Michael Psellus und Petrus Hispanus. Leipzig, 1867.

Preger, Wilir. Grschichte der deutschen Mystik im Mittelalter. München, 1874 .

Preston, 'T. S. God and Reason: Lectures upon the Primary Truths of Natural Religion. New York, Coddington, 1884.

1'risco, Giuserpe. Elementi di Filosofia speculativa. 5. ed., Napoli, 1879 ; Span. by Gabino Tejado, Madrid, 1866.

La Metansica della morale. Napoli, 1865.

Gioberti e la seolastica. Scienza e Fede, xxxvii.

Gioberti e l'ontologismo. Napoli, 1867.

Sull'opposto indirizzo della filosofia scolastiea e moderna considerazioni storico-critiche. Napoli, 1868.

Lo Heghellianismo considerato in se e nel suo svolgimento storico. Napoli, 1868.

Principii di Filosofia del Diritto. Napoli, Manfredi, 1872.

Proníszka, O. A causa formalis gyözelme a modern természetböleselet fölïtt. Böles. Foly., 1888.

Az értékek realizmusa. Bölcs. Fol., 1889.

Isten sis a világ. Exatergom, 1891.

A szabadakarat és a testmozgási mechanizmus. Bölcs. Fol., 1894.

Föld es sg. Esztergom, 1901.

Prosper, P. H. L'exposition litterale et doetrinale de la Somme théologique de saint Thomas d'Aquin. Lierre, Van In, 1894.

Protois, F. Pierre Lombard, son époque, sa vie ses écrits et son influence. P'aris, 1881. 
Peccisi, Roberto. La scienza e lateismo. Siena, s. Bernardino, 1890.

La scienzat e il libero arbitrio con appendice sul recente libro:

"Il pe-imi-mo " levoluzinne di G. Trezza." Sienal, s. Bernardinu, 1 sian.

Introduzione alla sociologia. Sirna, s. Bernardino.

II Progresio morale a le slle leggig. Niena, s. Bernardino.

La morale studiata mei suoi fondamenti. Sienas, s. Bernardino, 1902.

löitutu superiore di filonotia nell't niversita cattolicat di lovaina

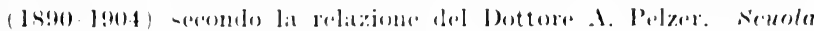
catt., 1904.

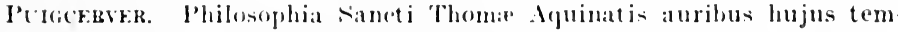
poris accommodata. 1824.

Quns, Broxamb. Philosophia mentalis. Prima Pars. logica. 1901.

Rines, L. Zur Plibesophio des Thomas zon Aguino. veue Kirchl. Zeitsch., 1890.

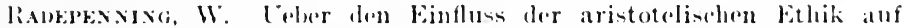
die Moral des Thomas von Aquino. Jema, 1875.

Ravziszewski, J. Odrodzenie filozofji scholastyeznej. Przeglad Filozoticzny. Warszawa, 1901.

Ragey, P. Vie intime de saint Anselme. Paris, 1sit.

Saint Anselme professeur. Ann. Philos. chr., $18 s 9$.

Histoire de saint Anselme. 2 vol., Paris, 1 sso.

Vir de saint Anselme. Paris, 1891.

Largument de saint Anselme. Paris, Delhomme \& Briguet, 1893.

RänsE, H. Des Joh. Frigena's Stellung zur mittelalter Scholnstik und Mystik. Rostock, 1874.

Rasellax, ('. Commentaria in Quastiones XXVlI LIX, 3. P. Summa Theologica de Mysteriis ('hristi in lectiones distributa. Div. Thom., 15!9-99?.

Ramize, S.J., H. Laccord de la philosophie de saint Thomas et de la science moderne an sujet de la composition des corps. Paris, $157 \%$.

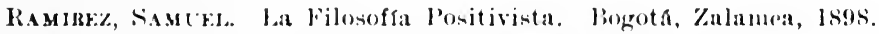

Ravi, Ebw. K. Johannes sicottus. Minehen, Beck, 1907.

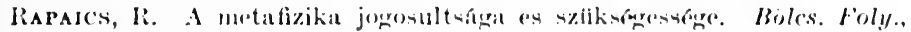
1900 .

Rasmona, H. Iniversities of burope in the lliddle Ages. Oxford, 18:\%.

Nicholas de Itltrieuria : a medieval llume. Proceded Aristotel. Soc., 1907 .

Rastran. Inatitutiones philonophiea. lienova, 1874.

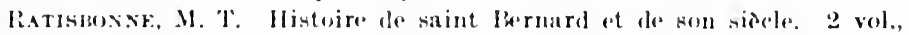
Paris, lstl; ti. ed., 18tit; Engl. by H. (i. Manning, Dublin, 1859.

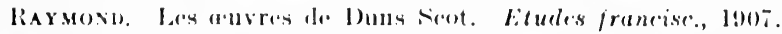

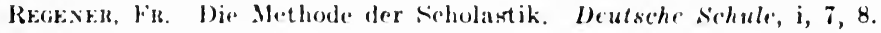


ne RGgxox, S.J., Tufonore. Bannez et Molina, histoire. doetrines. critique métaphysique. Paris, Oudlin, 1883.

Nature de la science métaphysique. Ann. Philos. chr., 1885.

Métaphysique des causes d'après saint Thomas et Albert le Grand. Paris, Retaux, 1885; 2. el., 1906.

Travaux contemporains sur la question du libre arbitre. Etudes relig., 1888.

Bannésianisme et Molinisme. Science eath., 1889.

Bannesianisme et molinisme. Etablissement de la question et défense du molinisme. Paris, 1890.

Regort, L. De H. Thomas van Aquino en Kant. Een strijl van twee werelden. studien, 1904.

Reimers, J. Der aristotelische Realismus in der Frühscholastik. Ein Beitrag zur Geschichte der Lniversalienfrage im Mittelalter. Aachen. Schweitzer, 1907 .

Reiner, Jos. Der Aristotelische Realismus in der Frülıscholastik. Aachen, Schweitzer, 1907.

Reinstader, Skis. Elementa Philosophiæ Scholasticæ. Friburgi. 1901 ff.; 3. ed., 1907.

Reitz, J. Dic aristotelische Materialursache. Philos. Jahrb., 1893.

Remrr, S.J., Vinc. Summa prælectionum philosophiæe scholasticæ. I vol., Prati, Giacchetti, 189.).

de Remusat, Charies. Abélard. Paris, 1845.

Saint Ansclme de Cantorbery. Paris, 1853; 2. ed., 1868.

Bacon: sa vie, son temps, sa philosophie. Paris, 1857.

Revax, Ensest. Averroes et l'Averroisme. Paris, 1852; 3. ed., 1866.

De philosophia peripatetica apud Syros. Paris, 1852.

Rengifo, Francisco M. Santo Tomás de Aquino ante la ciencia moderna. Rev. Col. del. Rosario, 1906.

Repetitorium der Philosophie fiir Studierende der katholischen Theolorie. Nach 1)r. Stöckl's Lehrbuch der Philosophic. Mainz, 1899.

Restrepo Jlerxíxdez, Julí́n. Leceiones de Lógica dietadas en el Colegio Mayor de Ntra. Señora del Rosario. Bogotá, imp. Colombia, 1907.

RetTrerg, F. Occam und Luther. Stud. u. Krit., 1839.

Recscir. F. II. Die Fiilschungen in den Tractat des Thomas von Aquin gegen die Giriechen. Mïnchen, 1889.

Revolio, Penno M. Religrion y Ciencia. Mutua Correspondencia y Harmonía de ambas. Barranquilla, 1904.

Rey. I. l'wurre philosophique de Mgr. dllulst. Rer. eath. des Rer., 1897.

Reycald, AldBert. ('atholic Philosophy. I. T. Rev., 190s.

Rézbixya, J. Az ókor kulturája. Pées, 1888.

A secpticizmus as kïvetkezmenyei. Böles. Foly., 1889.

Rinera, Jit. ()rígenes de la filosofía de Ramundo Lullo. Madrid, Suare\%, 1899. 
Rumersixges, r. H. Epitome Philosophia chrintianar. V. I. Introductio al universam philosophiam, logicat. Placentiar. lsa!s.

Logica. Tabular syopticae. Placentiar. 1901.

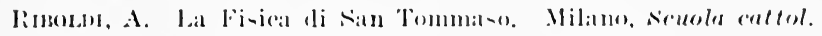

Racham, Jax. Eudes sur la mysticisme spéculatif de salint Bonaven. ture, decteur du Xlll, siecle. Heidelbere, lstis.

Richarr, T. Etule eritipue sur le but et la nature de la scolatstigue. lier. thom.. 19004-5.

Ricuteks, A. Wesenherit und Dasein in den (ieschipfen nach d. Tehre d. H. Themas von Apuin. Regenstrurg, 18si.

lickany, S.l., Joux, First Principles of Knowledge. New York, linnziger, 1ss9): 22 ed., london, Longmans, 1901.

(ieneral Metaphy-ies. Tew York, Benziger, Is!0; 3 ed., London, l.ongmans, 1!10:2.

Spirit and its struggles after a Definition. Wonth, Ig0).

Rickamy, S.J.. Joseph. Moral Plilomophy or Ethies and Natural law. New York, lenziger, 1ssa; 3 ed.. London, Longmans, 1903.

Aquinas Ethicus, or the Moral Teachinge of St. Thomas. New York, 1892.

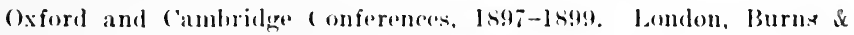
Oates, 1900.

Political and Moral Fsisays. New York, Benziger, 1902.

Free-will and four ronglish Philosephers: Hobhes, locke, llume and Mill. London, Burns \& (hates, l!oti.

of ciod and llis ('reatures fannotated lingl. transl. of the Simmu contra (ientiless). london, 1906.

Rits. J. Die Cottestehre des hl. Bermard. Juhrb. Ph. sp. Th., 1906.

bas geistliche leben in seinen lentuicklungsstufen nach der lehre des hl. Barnard. Froiburg, Herder, Jeoti.

Rintrer. Axpox. Die Moral des hl. Thomas ron Aquino. Milnchen. 1858.

Ruse, J. H. Reger bateon and lord Bacon. Methed. Quart., xviii.

Rigic, .I. .1. St. Anselm of ('anterbury. Lomlon, Js!)ti.

LF: Ritixiso, A. M. P'rincipio protologieo dell'intelligenza umana, ossia il vero concetto dell'Itinerarium mentis ad Denm di sian Bona venturat. Romat. Istiz.

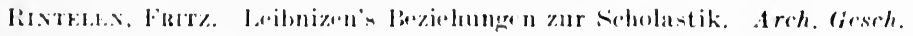
Philss., 1!)(1)-3.

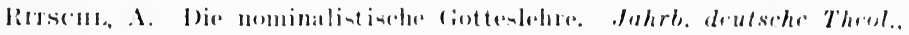
Intis.

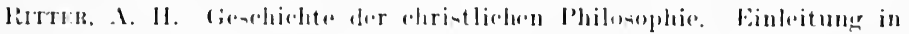

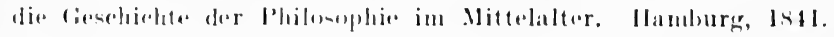

Platen und Arietoteles im Mittelialter. Philologges, Isteti.

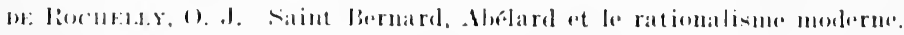
Parin and layon, Intiz. 
Ronkiguez de C'epeda. Eléments de Droit naturel. Trad. de l'esp. par A. Onclair. Paris, Retaux, 1890.

Rolfes, Eugex. Die aristotelische Auffassung vom Verhältnisse Gottes zur Welt und zum Menschen. Berlin, 1892.

Die Textauslegung des Aristoteles bei Thomas von Aquin und bei den Neuren. Jahrb. Ph. sp. Th., 1894.

Die vorgebliche Präexistenz des Geistes bei Aristoteles. Philos. Jahrb., 1895.

Die substanziale Forme und das Begriff der Seele bei Aristoteles. Paderborn, 1896.

Die Controverse über die Möglichkeit einer anfanglosen Schöpfung. Philos. Jahrb., 1897.

Die Gottesbeweise bei Thomas ron Aquin und Aristoteles erklïrt und vertheidigt. Köln, 1898.

Des Aristoteles Schrift ïber die Seele ïbersetzt und erklärt. Bonn, Hanstein, 1901.

Die Unsterblichkeit der Seele nach der Beweisführung bei Plato und Aristoteles. Philos. Jahrb., 1902.

Aristoteles' Metaphysik. Cebersetzt und mit einer Einleitung und erklärenden Anmerkungen versehen. Leipzig, 1904.

Zum Gottesbeweis des hl. Thomas. Herrn Prof. Simon Weber in Freiburg zur Erwiderung. Jahrb. Ph. sp. Th., 1907.

Ronayne, S.J., Maurice. Religion and Science: Their Union Historically Considered. New York, Collier, 1879.

God Knowable and Known. New York, Benziger, 1888; 2. ed., 1902.

Rondina, S.J., Fraxc. X. Compendio de philosophia theoretica e pratica para uso da mocidale portuguesa na China. 2 vol., Macau, $1869-70$.

Roquetre, G. Saint Bonaventure et son siècle. Paris, sixième centenaire, 15 juillet 1874 .

Le Cardinal saint Bonaventure. Lyon, 1874.

DE la Rosa, Agustín. Consideraciones filosoficas sobre la Verdad y la Certidumbre. Guadalajara, 1870.

Roselit, Saly. Mar. Compendium Summa philosophicæ. Rome, 1837. Rosin, D. Die Ethik des Maimonides. Breslau, 1876.

Rosset, Michaelis. Prima principia scientiarum, seu philosophia eatholica juxta D. Thomam ejusque interpretatores respectu habito ad hodiernam disciplinarum rationem. Paris, Vives, 1866; 2. el., 1873.

Rossignoli, Giov. Principii di Filosofia secondo la dottrina di San Tommaso esposti ad uso principalmente dei Seminari. 2. ed., Novara, 1889.

Natura e elassificazione delle potenze dell'anima. Palermo, 1892.

I] determinismo nella sociologia positiva. Nuova rivendicazione del libero arbitrio contro sofismi nuovi o rinovellati. 2. ed., 
Siena, s. Bernardino, 1901: Span. by M. Garcia Barzanallana, Barcelona, 1903.

Rossigxol, (iIov. Lat scienza della religione esposta in compendio ad uso delle seuole. Parma, Fiaceadori, 1901.

lat modernita. il moderuismo e la riforma scolastica dei nontri Seminari. Semola cattol., 1907.

Rotue, Taxcrione. Traite de droit naturel theorique et applique. Paris, Latrose, $1892-96$.

Rothexflet, s.J., Fraxc. Institutiones l'hilosophise theoretice in uжum prelectionum. Lyon and Paris, ed. altera, 1846-52.

Rort, F. A fogalmak tárgyi erteke. Böles. Foly. 1899.

A belsï erzekräl. Boles. Foly., 1901.

Darvinizmus es kifejlödes. Bülcs. Foly., 1904.

A croda termézettudomínyos szempontból. Budipest, 1907.

Rotre, S.I., Lcciex. Doctrines et Prohlemes. Paris, Retaux, 1900.

De Rocssatx, L. Elements de Logique. Bruxelles, 1894.

Rocssizor. Etudes sur la philosophie dans le moyen age. 3 vol., Paris. $1840-42$.

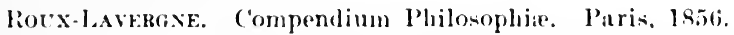

Royce, Josian. Pope Leo's Philosophical Movement and its Relation to Modern Thought. Boston Erg. Transeript, luly 29. 1903; Rer. C'ath. Pedag.. l!903.

Remaxi. Lezioni elementari di firiea. Bologna, Jsso.

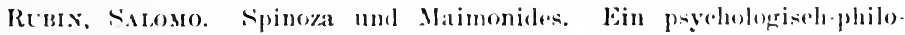
sophisclese Aut itheton. Wien, lsist.

Heidenthum und liablala. Dir kabulistische Mystik, ihrem Iroprung wie ihron Wesen nach grïmllich alufgehellt und populiir darpentellt. Wirn. 1s!33.

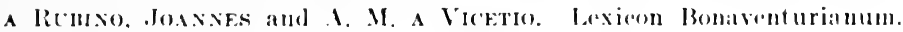
Venice, Jisto.

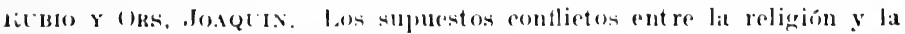
(iencia, a la obra de Drajer ante a Tribunal del sentido comán. de lat ram y de la historia. Mallad, less.

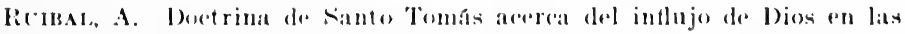
aeciones de las eriaturats racionales $y$ sobre la cieneia media.

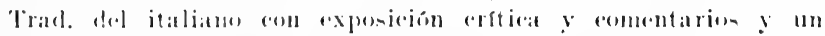
entudio de los puntos fundamentales de la preceiencia y coopera. rión divinat. Sintiatgo, 1901 .

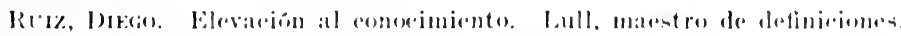
Nueva diuertacion solire los principios del metodo en lat historiat

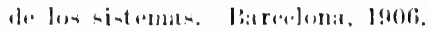

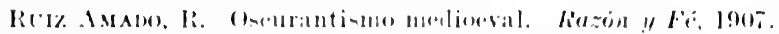

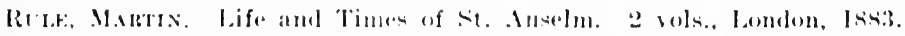

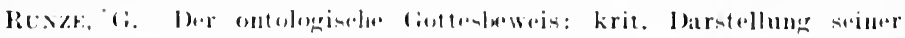

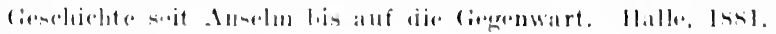


Russo, S.J., Nicolaus. Summa philosophica juxta scholasticorum principia. Boston, 1885.

De philosophia morali pralectiones. Neo Eboraci, Benziger, 1890.

SACus, Jos. Grundzüge der Metaphysik im Geiste des hl. Thomas von Aquin. Paderborn, 1896.

de Saint-Ellier, L. Pourquoi faut-il croire en Dieu? Réponse de la science. Paris, Bonne Presse, 1900.

La Providence. Dieu s'occupe-t-il de nous? Paris, Bonne Presse, 1901 .

SaIsset, E. Essais sur la philosophie et la religion au XIX. siecle. Paris, 1845.

Roger Bacon, sa vie et son auve. Rev. des Deux Mondes, 1861.

Précurseurs et disciples de Descartes. Paris, 1862.

Sala, E. Metafisica. Vol. I: Teodicea. Cremona, 1902.

Salerno, Stefaxo. Compendio ragionato della filosofia basata sopra la dottrina dell'Angelico Dottore San Tommaso e riordinato per domande e riposte, all'uso degli alunni dei Seminari, Instituti religiosi e Scucle liceali. Riposto, Denaro, 1898.

Salis Seewis, S.J., Fraxcesco. La scienza materialistica e le cause finali. Civ, catt., 1877-79.

Della conoscenza sensitiva. Prato, Giacchetti, 1881.

La vera dottrina di San Agostino, di San Tommaso e del P. Suarez contro la generazione spontanea primitiva. Roma, 1897.

Saiomon, Michel. Cne vue de la philosophie du siecle. Quinzaine, 1901.

Salvaxy, M. El concepto de Dios segun Santo Tomás. Rev. de España, 1885.

SAINator, Mescio. In Epistolam Encyclicam S. S. D. N. Leonis D. P. Papa Xlll D. Thome Aquinatis philosophiam instaurantis vicesimo recurrente anno obsequium. Foggia, 1899.

DE SAx, S.J., Louss. Institutiones metaphysice specialis. Vol. I. Cosmologia. Lovanii, 1881.

Tractatus de Deo uno. Pars Prior preter tres partes prioris ipsius tractatus continens disquisitionem de mente $\$$. Thome eirca Prodeterminationes Physicas. Lovanii, Peeters, 1894.

Sixdonfry, F. Gondolkodástan. Gyula fehérvár, 1888.

Istentan. Gyula fehérvár, 1890.

Saxseverixo, (AJetaxo. Institutiones logica et Metaphysica. Neapoli, 1851 .

Philosophia christiana emm antiqua et nova comparata. Neapoli, 1862.

Elementa philosophiae christiane. Neapoli. 1864; French by Corriol, Avignon, 1sit.

saxs-Fin. De lorthodoxie de lOOntelogrisme modére et rationnel. Nincy, Bordes, lstig. 


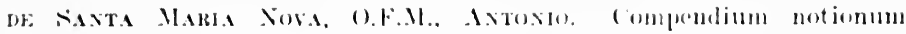
philosephicarum sub dialegi format. Ad claras Apuas, lssti.

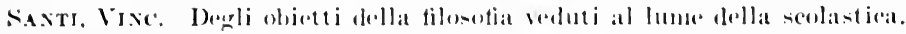
Perugia, Is!o.

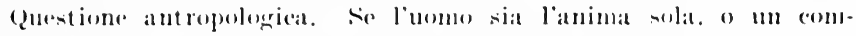

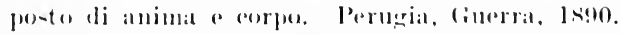

la guestione fondamentale della teologia naturale. Perugia, (iuera. 1 sis?.

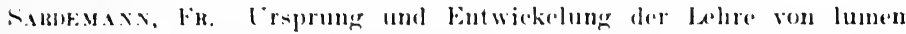
rationis aternee, lumen divinmu, lumen naturale, rationes seminales veritates ternie, his leneartes. Kassel, Raitterer, 1902.

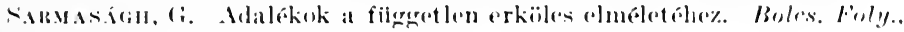
$1496 \%$.

Soroms, las. Euchiridion Philosophiar: Pars Prima complectens Logican universam. Bruma, lssis.

In Summam theologiean Divi Thoma Aquinatis. De Trinitate. prabectiones habita in pontificio seminario romallo et enllegin urbano. Romie. Propaganda, lssi.

1) habitibus doctrina 5 . Thoma Aquinatio in 1-2 1 Summar Theologioar. Romar, 1897.

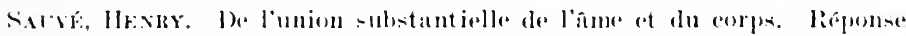
an li. l'. Bottallat. Paris, Berehe \& Tralin, lsis.

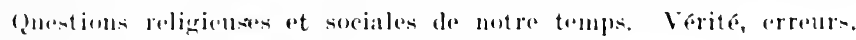
opginions libres. 2. ed.. l'aris, lssis.

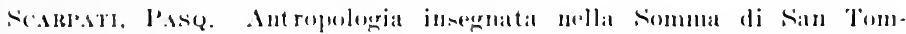

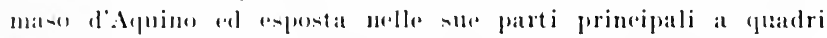

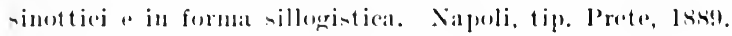

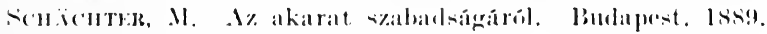

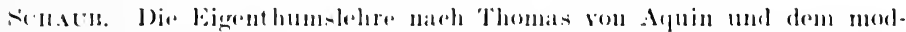

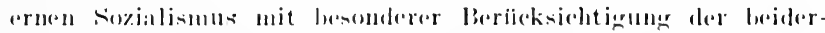

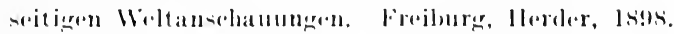

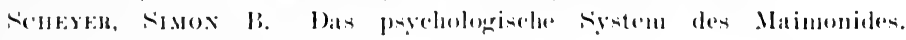
lirankfurt, 1s.5.

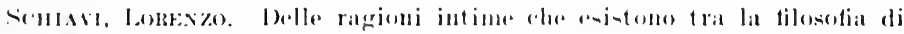

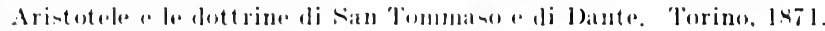

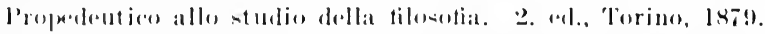

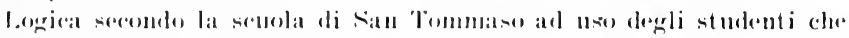

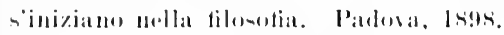

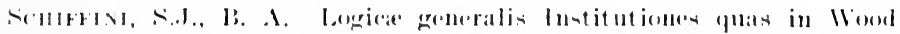

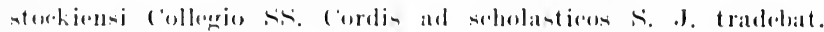
Ex typis rollonii, 18i3.

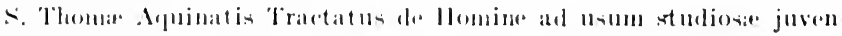
tutis aceommedatus. Windutork Marylandiar, Isteg.

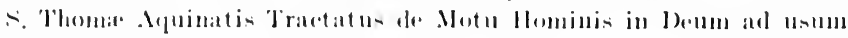

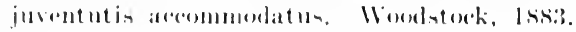


Schiffini, S.J., Saxctus. Principia philosophica ad mentem Aquinatis. Augustre Taurinorum, Speirani, 1886; 2 . ed., 1894.

Disputationes metaphysica specialis. Augustæ Taurinorum, Speirani, 1888.

Institutiones philosophicæ ad mentem Aquinatis tribus voluminibus jam evoluta, ab eodem auctore nuper in compendium redactæ. Augustæ Taurinorum, 1889.

Disputationes philosophiæ moralis. 2 vol., Augustæ Taurinorum, 1891.

Schiltz, Petr. Summa philosophica ad mentem D. Thomæ Aquinatis in usum Seminarii Luxemburgis. Luxemburg, $1894 \mathrm{ff}$.

Schindele, St. Beiträge zur Metaphysik des Wilhelm von Auvergne. Inauguraldissertation. München, 1900.

Zur Geschichte der Unterscheidung von Wesenheit und Dasein in der Scholastik. München. Hofbuchdruckerei, 1900.

Die aristotelische Ethik. Darlegung und Kritik ihrer Grundgedanken. Philos. Jahrb., 1902-3.

Schropps, Lor. La psicologia tomistica e la moderna psichiatria. Napoli, Pisanzio, 1895.

Scrilosser, Fr. Chr. Abälard und Dulcin: Leben und Meinungen eines Schwärmers und eines Philosophen. Gotha, 1807; Paris, 1839.

Scumd, Aloys. Die thomistische und scotistische Gewissheitslehre. Dillingen, 1859.

Die perip.-schol. Lehre von den Gestirngeistern. Athaencum (München), 1862.

Erkenntnisslehre. 2 vol., Freiburg, 1890.

Das Causalitätsproblem. Philos. Jahrb., 1896.

Scmmo, Fravz. Die Kategorie der Quantitiat. Zeitsch. kath. Theol., 1889.

Verhältniss der Quantitiit zur Substanz. Zeitsch. kath. Theol., 1890.

Der Begriff des "Wahren." Philos. Jahrb., 1893.

Sсhмidt, Heinrich. Der Mysticismus des Mittelalters in seiner Entstehungsperiode. Jena, 1824.

Schmied, A. Studien iiber jiidisehe, insonders jiidisch-arabisehe Religionsphilosophie. Wien, 1869.

Scrmitт, A. Zwei noch unbenützte Handsehriften des Johannes Scotus Erigena. Bamberg, 1900.

ScimitT, J. IIegel dialektikájának titka. Budapest, 1892.

Scimmolders. Documenta philosophice Arabum. Bonn, 1836.

Essai sur les écoles philosophiques chez les Arabes et notamment sur la doetrine d'Algazzali. Paris, 1842.

Scmmörier, L. Die scholastische Lehre von Materie und Form. Neuerdings dargestellt mit Riicksieht auf die Tatsachen und Jehren der Naturwissenschaft. Passau, 1903. 
Sonxtrmaxx, s.J. Controver-iarum de divine gratia liberique arbitrii 'onecrelia initia et progresisus. Freiburg. Issl.

Scoxem, Matulas. Aristoteles in der scholastik. Fin Boitrag zur Gesehichte der Philosophio im Nittelalter. Eichstidt, 1875.

Die Kärperlehre des Joh. Duns Scotus, und ihr Verhältniss zum Thomismus und Atomismus. Mainz, Kirchheim. Isig.

Die Philosophie des hl. Thomas und ihre Bedentung fiir die Ciegenwart. Wiirabung. lssis.

Die philosphisehe Lehre von Ramm und Zeit. Mainz, 1886.

Saturplitocophie im Geiste des hl. Thomas. Paderborn. Schöningh,

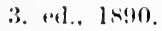

Die Willensfreiheit des Mensehen und ihre hentigen Gegner. Der Kutholik. Mainz, 1890.

Perchologio in Gejste des hl. Thomas von Aguin. Paderborn. Sihöningh, $180: 2$.

Scunfune, Aktulk. Die Psyehologie Alberts des (irosien (Beitrigar). Miill-tor. 1903-6.

scoxrater, ('. M. Natur. Lermunft, fott. Abhandlung iiber die natiirliche Erkenntniss Gottes nach der lephre des hl. Thomas von Aquino. Regensburg, lssis.

Das Wisen fottes nach die Lehere des hl. Themals ron Apuino.

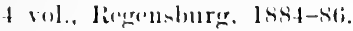

Die katholisehe Wahrheit oder die theol. Summa, deutach ron (. M. Schneider. Regenslurg, Issio-s9.

Die Cirmolprincipien des hl. Thomat und der mederne Socialiamus. Jahrb. Ph. sp. Th.. 1s!13-!)t;.

ScHsaner, L. Roger Bacen. Auguburg. 1si3.

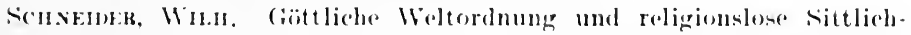

keit. \%eitgemisse Erörterungen. Paderborn, Sihöningh, 1900.

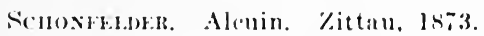

Scht trrss. Kart. l)ie siagen iber sylventer ll (fierbert). llamburg. 1893.

scme Machers. Matrukw. The knowableness of God. Its Relation to the Theory of Knowledge in St. Thomas. Notre lame. Indiana, Iniversity l'ress, 1905.

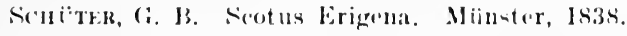

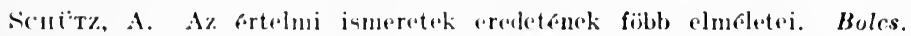
Foly., 1903.

Kezelet es verg a világolyamatoklunn. Burlupest, 1907.

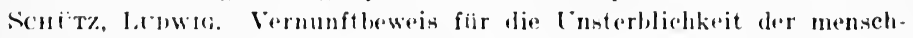

lichen Serele. Paderborn, 1sit.

Enfreiheit und Freileit des mensehlichen Willens. 1877.

Einleitung in lie Philosephie. Paterborn, 1879.

I).r cougenannte Veretand der Thiere. 1880. 
Sonity. Lenwig. Thomas-Lexicon. Simmlung, lebersetzung und Erklïrung der in saimmtl. Werken des lil. Thomas von Aq. vorkommenden Kunstausdriieke und wissenschaftl. Aussprüche. Paderborn, 1881; 2. ed., 1895.

Ueber Wissenschaft und Offenbarung. 1884.

Der hl. Thomas und scin Verständniss der Grieehisehen. Philos. Jahrb., 1895.

In welchem Zeitpunkte tritt die vernünftige Seele des Menschen in ihrer Korper ein? Freiburg, 1898.

Schwalm, O.P., M.B. La propriété daprès la philosophie de saint Thomas. Rev. thom., 1895.

L'action intellectuelle d'un maître d'après saint Thomas. Rev. thom., 1900.

Schwets. Institutiones philosophice. Vienna, 1873.

Scotus, Joannes Duxs. Opera omnia. Editio novissima juxta editionem Waddingi a PP. Francisc. de observ. accurate recognita. 26 vol. in-4, Parisiis, Vives, 1891.

Secrétax, Charles. La restauration du thomisme. Rev. Philos., 1884.

Seeberg, Reinhold. Die Versöhnungslehre des Abälard und die Bekämpfung derselben durch d. hl. Bernard. Mitt. u. Nachr. f. d. evang. Kirehe in Russl., 1888.

Die Theologie des .Johannes Duns Scotus. Eine dogmengesehichtliche Untersuchung. Leipzig, 1900.

Segura, Andrés. Discurso pronunciado en la solemne Distribución de Premios del Seminario C'oneiliar de León, año de 1879. León, 1879 .

Seipel, Igraz. Die Lehre von der göttlichen Tugend der Liebe in d. Petrus Lombardus Biichern der Sentenzen und in der Summa theologica des hl. Thomas von Aquin. Der. $K$., 1906.

Semeria, Grovaxis. Scienza e Fede e il loro preteso conflitto. La Critica della Scienza. Roma, Pustet, 1903.

Sentroul, ('. L'objet de la metaphysique selon Kaut et selon Aristote. Louvain, 1905.

Vrai thomisme contre vrai kantisme. Rev. Néo-Scol., 1906.

Le subjectivisme kantien. Réponse à M. l'abbe Farges. Rev. thom., 1907.

Sertillaxas, O.P., A. D. La preuve de l'existence de Dieu et l'éternité du monde. Rev. thom., 1898.

L'art et la morale. Paris, Bloud, 1899.

Nos vrais ennemis. Rev. thom., 1902.

Ies bases de la morale et les réeentes discussions. Rev. de Philos., $1902-3$.

Lidee de sanetion peut-elle servir a prouver Dieu. Rev. thom., 1903.

L’idée de Dieu et la vérité. Rev. thom., 1904-5. 


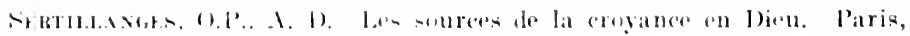
Perrin. 1901: 11. ed., 1904).

Agnosticiome on anthropomorphi-me. Rer. de Philos., 1906.

la eonnationate de Dien. Rere de l'hilos., loget.

Lidere de rration dans saint Thomas d'Aquin. Rre set. philos, ot theol., 1910 .

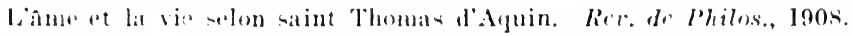

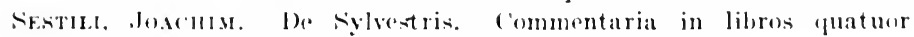

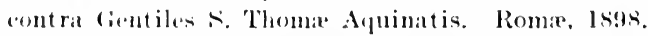

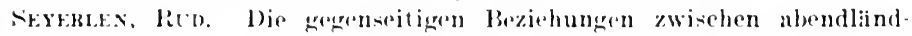
i=cher mud norenetlindischer Wisenschaft, mit besonderer Rieksicht unf sialomon iln (iabirol und seine philosophiselse Bedeutung. lepipzigr. Kaufmann, 1900.

silallx, Thusas J. The Middle Ages. Sketchea and Fragments. New York, Bromiger. 1905.

silaxalux, Eumton T. Roalistie Philosophy: Its Sitrength and Weakuns. rath. Enil. Bull., ls!to.

John Finke on the Idea of Ciod. C'ath. I'niv. Bull., 1897.

'The ldea of liend in the Iniverse. rath. I'nir. Bull, ls98.

The Fallacy in Folution. ('ath. linil. Bull., l901.

The language of Evolution. C'ath. Cnil. Bull., 1901-2.

sinfa, Cifobor. Some facts and Probabilities Relating to the History of Johanmes feotus surnamed l)uns and concerning the genuinenese of the Siganoletto Portrait belonging to the Cieneral Theo-

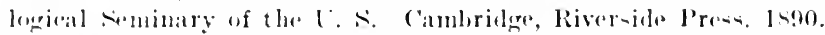

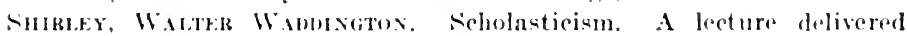

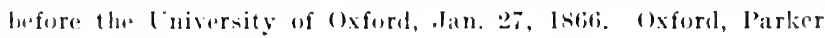
\& ('o, listiti.

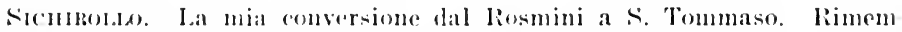
branze di stuli filosofici. Padova, lssiz.

sienser, H. liselichte der l'sychologic von Arist. his Thomas von Aguino. liotha, list.

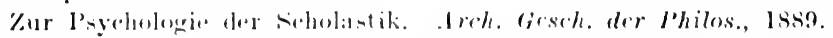

leber die Eut-tehung der Termini" natura naturant" und " natura naturata." Arrh. (iesth. Philos., Jsim.

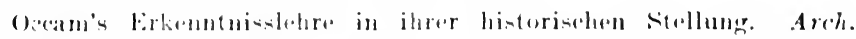
liasch. Philos., lagt.

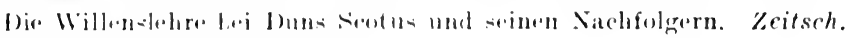
f. Ih. u. ph. Hrit., lsis.

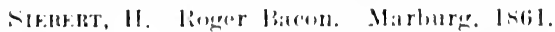

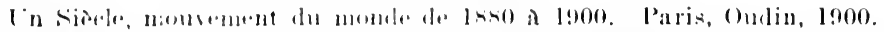

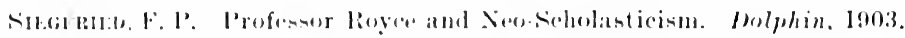

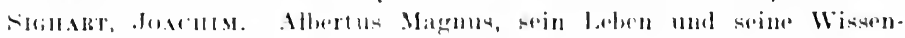

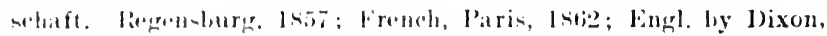
lomben, Isti. 
Signorieilo, Nuntio. Lexicon Peripateticum Philosophico-Theologicum in quo scholasticorum distinetiones et effata præcipua explicantur. Neapoli, $1854 ; 2$. ed., 1872.

Philosophia moralis. Neapoli, 1876; 3. ed., 1883.

Silbernagel, T. Wilhelm von Oceam's Ansichten iiber Kirche und Staat. Hist. Jahrb., vii.

Simar. Die Lehre vom Wesen des Gewissens in der Scholastik des XIII. Jahrhunderts. Freiburg, 1885.

Simeterne, R. Sur les condamnations d'Aristote et de saint Thomas. R. prat. d'apolog., 1908.

Simon, Jules. Abelard et la philosophie au XII. siècle. Rev. des Deux Mondes, 1846.

Sinibald, Jac. Prælectiones philosophiæ christianæ ad mentem S. Thomæ Aquinatis. Coimbra, $1889 \mathrm{ff}$.

Elementos de Philosophia. 2 vol., Coimbra, 1892; 2. ed., 1894.

Sistema fisico di San Tommaso. Cir. cattol., 1891.

Sistini, O. Lettre romaine: Le mouvement thomiste a Fome. liev. Néo-Scol., 1907.

Slattery, J. R. Scholastic Methods, their Advantages and Disadiantages. Amer. Eccles. Rev., 1900.

Slevix, T. J. Order in the Physical World and its First Cause according to Modern Science. Transl. from the French. London, 1891.

Snell, M. M. The Triumph of St. Thomas. Dublin Rev., 1839.

Soldana, M. La verdad transcendental segun la filosofia escolistica. Santander, Oria, 1907.

Soler, ANT. Biografía del D. J. Balmes. Madrid, 1850.

Solimaxi, A. Divagazioni filosofiche intorno ai sommi filosofi Tommaso d'Aquino e Antonio Rosmini. Milano, 1886.

Solmanus, S.J., Dominicus. D. Solimani, S.J. in Collegio Romano professoris Philosophia moralis et juris naturæ Institutiones Ethica Dicalogiæ Eudæmonologiæ. Romæ, 1847.

Sollaxo y Dívalos, J. M. de J. Diez de. Logica Compendium juxta doctrinam S. Thome Aquinatis. Auctore P. C. Roux. In gratiam sui Seminarii ab Episcopo Leonensi multis annotationibus locupletatum. Leon, 1868; n. ed., 1900.

Vigesima segunda carta pastoral, que el primer Obispo de León, J). J. M. de J. Diez de Sollano y l). dirige á su Ilmo. y V. Cabildo, a su Seminario Conciliar, ete., publicando la encíclica de N. S. P. el Sr. León XIll que comienza " Eterni Patris" de 4 de Agrosto del presente año, sobre la Filosofía del Angélico Dr. S. Tomás de Aquino, León, 1879.

Theologica disquisitio in qua mens Ecclesiæ in definitione dogmatica de Immaculata B. Virginis Marix Conceptione cum mentem 1). Thome de eadem re comparata, evidenter monstratur, juxta philosophicum et theologicum ejusdem Angelici Doctoris 
systema, unam et eamdem esse, nec in apice discrepare. Leon, 1 ision.

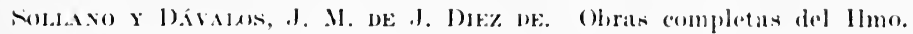
y Rmo. Ar. Dr. y Mtro. 1). .. M. J). de Sollano y J). . . coleceionadic por .J. Il. de Vermoy Parres. Mexieo, is!lt.

DA Solbexto. Boxir. S. Bonaventura o la sua dottrina. Napoli, 1890. sontas. S.J., tinstox. Triate de Philosophie. l'aris, Jethielleux, $1901 \mathrm{HT}$.

Do lat beatute lapress Platon. Aristote et saint Augustin. Paris, Ratatux, 1902.

Etudes philosophiques et sociales. Parie, Lethielleux, 1907.

1): Sol\%a, Joss: Sotmaxo. Licües de Phibsophia elementar racional e noral. Pernambuco. 1851.

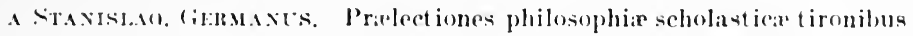
facili methodo instituendis aceommodatar. Romer. Pustet, 1903 If.

Starhahx, II. Ditu "opur majus" des Roger Bateon. Kirchl. Monatschr., 1593.

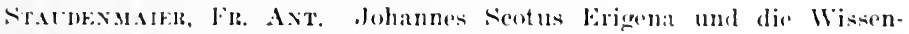
schaft soiner \%eit. Frankfurt-ia-M., 1934.

Sirfecz, (r. A Feehner-fale poche-phyoikai alapkeplet tarthatatlansága. Bisles. Foly., 1890.

A calculus infinitesimalis mivoltanak fontossályal kerestany biileseleti s\%mponthol. Büles. Foly., 18!):.

Streg, Jit. Johannis Scoti Erigene de verbo divino sententia, seu Christologia, Argentorati, lstii.

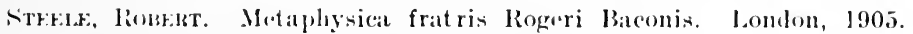

Straisi, A. San Tommaso. Bergamo, la00.

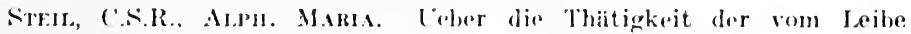
gat rennten menuchlichen firele vom standpunkte der Philorophie. Philss. Jahrb., 1901.

Das lheorem der menschliehen Wescuseinheit in eonseguenter Durelifiihrumg. Plilos. Jahrb., 190:2.

strax, Moses Mamonides. Lat Haye, Jitti.

Srras, L. Antike und mittelalterliche Vorlianfer des ocoasionalismus.

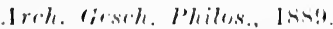

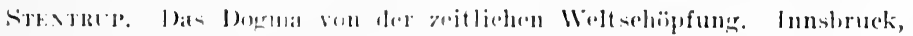

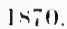

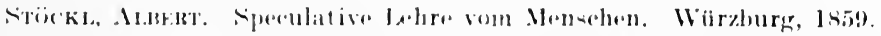

1), argumento, ut vocint, ontologion. Monasterii, 1stiz.

Geschichte der Philowophie des Mittelalters. Mainz, Istit-60.

J) Joh. Seroto Erigena. Mian-tar, letiz.

lahrbuch der Philemephie. 3 vol., Manz, lstis; 7. ed., ls!2.

thid. Neu hearlextert von (i. Wohlmuth. Mainz, 190).

L.hrbuele der firsehichto der Philowophie. 2 vol., Mainz, 1870; 3. ed., 1 ssis?. 
Stöckl, Albert. Grundriss der Aesthetik. Mainz, 1971.

De S. Anselmi de liberi arbitrii notione sententia. Ind. lect. Monaster. per monses astiv., 1871.

Die thomistische Lehre vom Weltanfange in ihrem geschichtlichen Zusammenhange. Katholik, 1883.

Gesehichte der neueren Philosophie von Baco und Cartesius bis zum Gegenwart. 2 vol., 1883.

Lelırbuch der Aesthetik. Mainz, 1889.

Geschichte der christlichen Philosophie zur Zeit der Kirchenväter. Mainz, Kirchheim, 1891.

Grunzüge der Philosophie. 1892.

Grundgriss der Geschichte der Philosophie. 1894.

Lehrbuch der Apologetik. Mainz, Kirchheim, 189.).

Dr. Albert Stöckl, Domeapitular und Lycealprofessor in Eichstaitt. Eine Lebensskizze. Verfasst von einem seiner Selüiler. Mainz. 1896.

Stölzle, Remigius. Abaelards verloren geglaubter Tractat " De unitate et trinitate divina." Histor. Jahrb. d. Görresgesell., xi ; München, 1890.

Abaelardo. $1121 \mathrm{zu}$ Soissens verurtheilter Tractatus de unitate et trinitate divina. Aufgefunden und erstmals herausgegeben. Freiburg-i-B., Herder, 1891.

Stonyhurst Philosophieal Series. Cf. Boedder, Clarke, Maher, Rickaby. Stonss. Bernard of Clairvaux. New York, 1892.

Stössel, D. Salomo ben Gebirol als Philosoph und Förderer der Kabbala dargestellt. Leipzig, 1881.

Sträter, Hermaxn. Ein modernes Moralsystem. Philos, Jahrb., 1901.

Straub, S.J., Axton. Die Aseitiit Gottes. Philos. Jahrb., 1903.

Straub, Jorr. Der teleologische Gottesbeweis und seine Gegner. Würzburg, Stïrtz, 1894-95.

Gewissheit und Evidenz der Gottesbeweise. Philos. Jahrb., 1897.

Strobel, A. Die Lehre des sel. Albertus Magnus iiber das Gewissen. Sigmaringen, 1901.

Stuchicer, J. Az életelv egysége az emberben. Böles. Foly., 1900.

Elet es öntudat. Böles. Foly., 1902.

Az öntudatlan a psychologiaban. Bölcs. Foly., 1903.

Suarez, S.J., Franciscl's. Opera. 26 vol., Besançon and Paris, 1856-62.

Opuscula sex inedita. Bruxelles, 1859.

Sucona y Valles. Metaphysiex adnotationes. Tarragona, 1883.

Philosophix Institutiones. Tarragona, 1886.

Suldivan, J. Marsiglio of Padua and William of Ockam. Amer. II ist. Rev., 1897.

Suríxy, J. John Stuart Mill szabadsúgtama. Böles. Foly.. 1900.

Sutík, J. Geometriai Axiómák. Böles. Foly., 1898. 
Sropcik. O.S.P. ('oxst. I'bersichtliche Darstellung und Prilfung der philosophischen Bawejor fiir dir Geistigkeit und die Custerblichkeit der menechlichen verele. Philos. fahrl.. Ists.

Swrerste, s. Abatard and bernatd. Biblioth. Sincra, xvii.

swotalsks. B. W. Des ('haldedius commentar zu Plato's Timaius (Beitrige). Mionster. Aichentortl, 190:2.

Dats leben der feele. Jianmolerg, 1900.

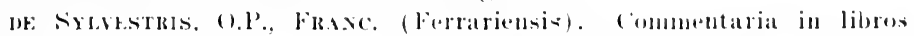

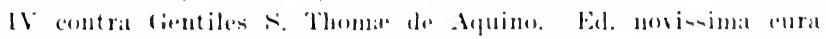
J. Sentili. Romat, Is!s tr.

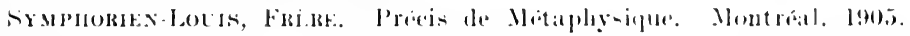

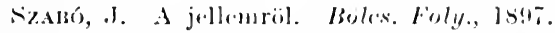

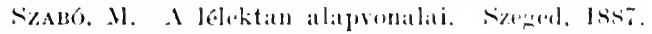

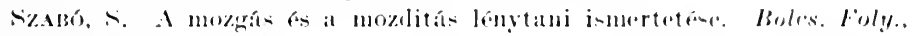
15!30.

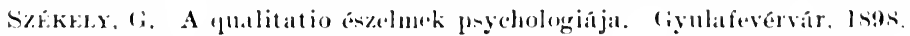

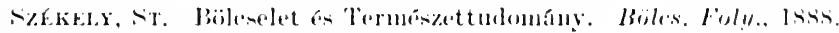

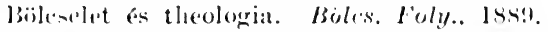

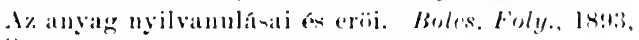

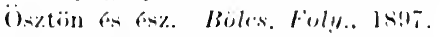

Esz és äztion. Nagyvárad, ls!s.

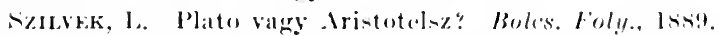

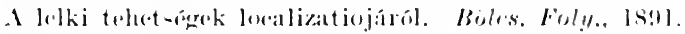

Fizika des metafizika. P'ées, 1s!4.

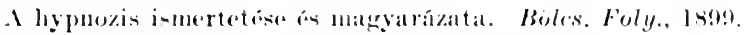

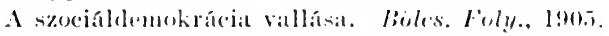

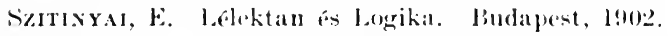

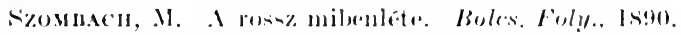

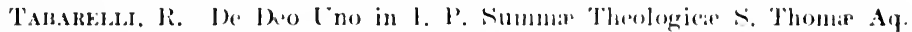
a Q. II ad (2. XIS. Romir. P'ustat, 1906t.

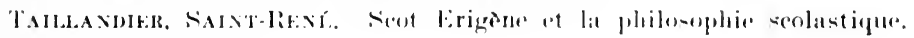
l'aris. Ist:i.

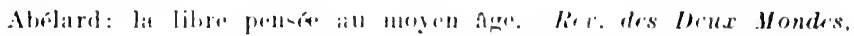
1 stil.

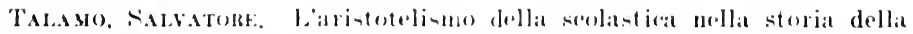

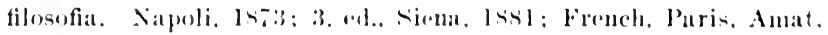
Itirit.

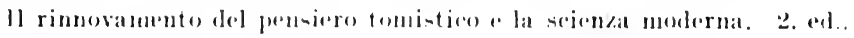
Siena, lsiti.

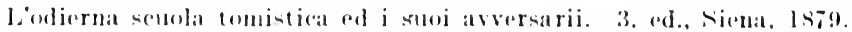

löneonscios dellollartmann, dineorse letto nell dee. di Roligione (attol. di Roma il di 1.5 Maggeno 1s79. Roma, lsige.

lina nuova forma di uscialismo. Note eritiche. Roma. Desclere, 19100.

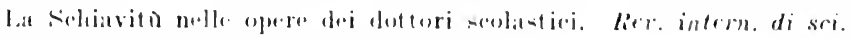

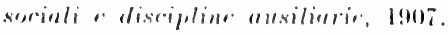


TApareli d'Azeglio, S.J., Luigi. Saggio teoretico di diritto naturale appoggiato sul fatto. Palermo, 1840-41; 6. ed., 1857; Germ., Regenshurg, 1845; French, Paris, 1857; Span., 2. ed., Madrid, imp. San José, 1884.

Corso elementare di Natural Diritto ad uso delle scuole. Napoli, 1843; Livorno, 1851; 6. ed., Napoli, 1860; French by Ozanam, Tournai, 1864; Span., Paris, Bouret, 1875.

Esame critico degli ordini rappresentativi nella società moderna. 2 vol., Roma, 1854; Span., Madrid, 1867.

Le Ragioni del bello secondo i principii di S. Tommaso. Roma. 1860 ; Span. by E. Danero, Madrid, 1879.

TARINo. Institutiones logica, metaphysice, ethic: atque juris nature. 2. ed., Biella, 1877 .

Problema fundamentale della scienza. 1878.

Templer, Berxh. Der Unsterblichkeitsglaube bei den jiidischen Philosophen des Mittelalters. Nebst Einleitung iiler den Unsterblichkeitsglauben in Bibel und Talmud. Wien, Breitenstein, 1895.

v. Tessex-Wesierski, F. Die Grundlagen des Wunderbegrifles nach Thomas ron Aquin. Paderborn, Schöningh. 1899.

'Tunmiri, E. J. De rationibus seminalibus et immanentia. Lille, 1905.

L'immanence et les raisons séminales, les problèmes de la vie et de l'action divines. Rev. sci. recl., 1906-i.

Thíkry. A. Was soll Wundt für uns sein? Rer. Xco-scol., 1898.

Le tonal de la parole. Louvain, Inst. sup. de Philos., 1901.

'Tullu, J. Das Fundamentalprincip aller Wissenschaften. Philos. Jahrb., 1891.

'Thomas Aquinas. Opera omnia; 22 vol. fol., Parme, Fiacedori, 1866.

Opera omnia jussu impensaque Leonis XlIl P. M. edita. Romæ, $1882 \mathrm{fl}$.

Excerpta philosophica (arranged and edited by P. Carbonel). 2 vol.. Avignon. 1882.

('ommontaria in tres libros Aristotelis de Anima. Lovanii, 1901.

Ceber die Regierung der Fïrsten. De Regimine principum. Ein Compendium der Politik. Tebers. v. Th. Scherrer-Boccard. Lucern, 1897 .

('f. Rickaby, C. M. Schneider.

St. Thomas Aquinas and Medierval Thought. Dublin Rer., 1906.

Trïmss, Nis. Commentatio litteraria et eritica de $S$. Thoma Aruinat is operibus. Berolini, 1874 .

Divi Thome Aquinatis opera et pracepta quid raleant ad res ercelesiatsticas politicas sociales. Berolini, 1875 .

Türixg, If. Dir Willensfreiheit des Mensehen nach der Lehre des hl. Thomas von Aquino. Kathol. Sichureiz. Bl., 1891.

'Tut rot, Cuarlas. De lorganisation de l'enseignement dans l'Universite de Paris an moyen âge. Paris, 1850. 
Thux. P. Dewx eouvents au moyen age. ou l'Ahiaye de Saint dildas et le Paraelet au temps d'Abélard et d'Heloiste. Paris, 1851.

Tomcsixy, L. Az ember akaratának szabadsaga. Kalocsa, ls90.

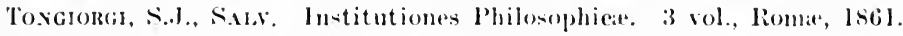
Institutiones philosephica $\&$. Tongrorgi. S.J., ab eodem in eom.

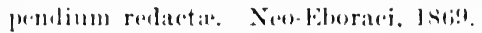

Intitutiones philosophia moralis in compentimus redactio. Ed. 3.. senis, 1s!)!.

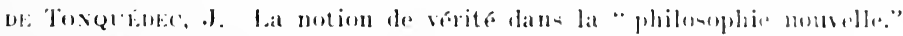
Fitudes, 1907 .

Torsatore, I. B. De natura rei materialis at immaterialis. Placentiar. 1sis.

Primeipia s. Thomar, quilus innititur doetrina " 1), "nte communi." Hir. Thom. Is!o).

1) humante rognitionis molo, origine ale profectu ad mentem sanet Thomir. Placentiar. 1s?)

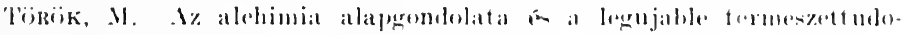

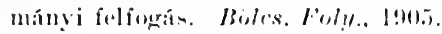

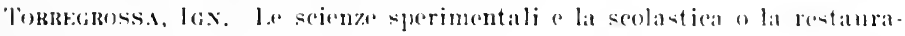
zione tilosutica. Palermo. lsing.

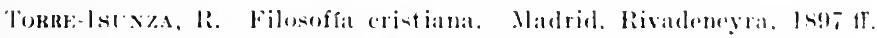

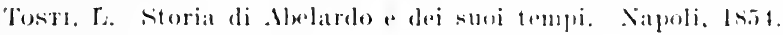

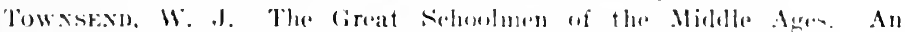
aceount of their lives, and the servieses they rendered to the

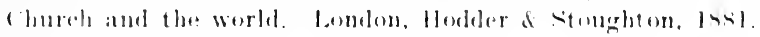

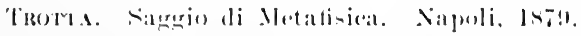

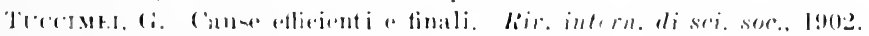

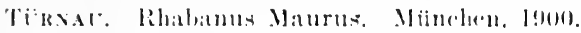

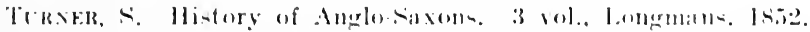

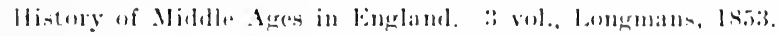

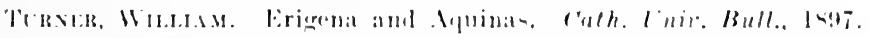

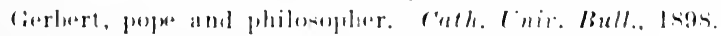

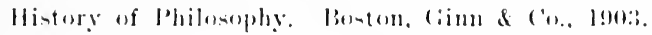

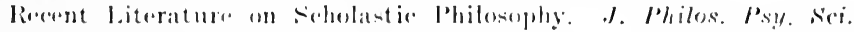
Meth., lanto.

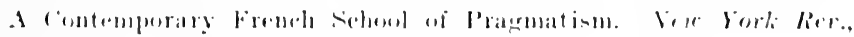
1906 ;

The catholie loont of liew in Philonophy. fmer. ('ath. Quart., 1907 .

Mnemente Vorses in a Ninth cintury . WS : A contribution to the llintory of longe. Philos. Rer.. later.

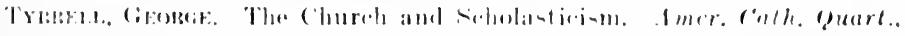
$18 ! 1$ s.

The Futh of the Millions. Jombon, longmant, 1962.

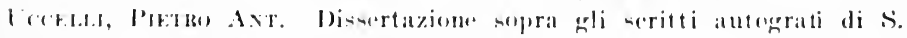
Tommanor d'Aluino. Malane. Ists. 
Uccelli, Pietro Axt. Memoria sui testi esaminati da San Tommaso d'Aquino nell' opusculo contro gli errori de'(ireci. Napoli, 1870.

Ude, Joansis. Doctrina Capreoli de influxu Dei in actus roluntatis humane secundum principia Thomismi et Molinismi collata. Græcii, Sumptibus "Styriæ." 1905.

Die Psychologie des Strebevermögens im Sinne der Scholastik. Graz, 1907.

Uebinger, Jos. Begriff der Philosophie. Philos. Jahrb., 1893.

lgarte de Ercilla, E. Método psicológico-experimental. Experimentación. Razón y Fé, 1907.

Carácter material, externo y divisible de la sensación. Razón " Fé, 1907 .

Ubrain, Carol. De concursu divino scholastici quid senserint. Paris, Thorin, 1894.

Urráburu, S.J., J. J. Institutiones Philosophicæ quas Roma in pontificia universitate Gregoriana tradidebat. \& vol., Vallisoleti, Hernandez, $1890 \mathrm{ff}$.

Origen de los seres vivientes, según sum diversas especies y examm del transformismo. Bilbao, 1896.

Principios fundamentales de Antropologia. Obra escrita en latin y puesta en castellano por A. Madariaga, S.J. Madrid, 1901.

Compendium Philosophire Scholastice. 5 vol., Matriti, Lopez, $1902-4$.

El verdadero puesto de la filosofía entre las ciencias. Ruzón y Fé, 1901-2.

El principio vital y el materialismo ante la ciencia y la filosofía. Razón y Fé, 1904-5.

VACANDARD, E. Abélard et sa lutte avec saint Bernard, sa loctrine, sa méthode. Paris, 1881.

Vie de saint Bernard, ablé de Clairvaux. Paris, 1895.

VAcant, J. M. A. De certitudine judicii quo assentimur existentie revelationis. Taranne, 1878 .

De nostra naturali cognitione Dei dissertatio. Taranne, 1879 .

Notes sur les séminaires de philosophie en France. Ext. de la Rev. des Sci. eccl., 1880.

Le mourement et la preuve de l'existence de Dieu par la nécessité d'un premier moteur. 1880.

Ia theorie de la connaissance selon saint Thomas d'Aquin et selon Duns Sicot. Ann. Philos. chr., 1889.

L'objet de l'entendement d'après saint Thomas ot d'après Dums Sicot. Ann. de Philos. chr., 1889.

La Parole rot le langage d'après saint Thomas et d'après Duns Scot. Ann. Philes. chr., 1890.

Etudes comparées sur la philosophie de saint Thomas et sur eelle de Duns Scot. Paris \& I,yon, 1891. 


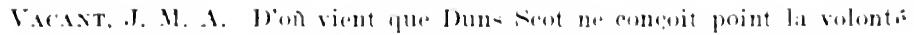
conme saint Thomas d'Aluin. Rer. du clerge frens.. 1sar.

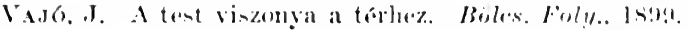

Vasmoxise. Eeperienza e ragionamento in Rogero Bacone. Romat, lis!ti.

Vanexsise, D) Ina diflicolta tilosotico-teologiea creduta inalubile. Nicastro, 1900 .

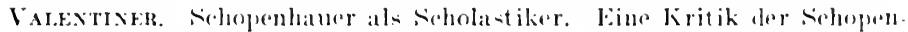
hatuerechen Philosophie mit Riicksicht auf die gesammere hant ische Nom-cholastik. lecipzig, 1!101.

Valexzera, Mario. Apuntamientos solore el principio de utilidat. Bogotá, imp. de Ortiz, 1857 .

Valfoga, Leosarog. Inel Tradizionalismo e del simirationalismo. Gienova, $18(i)$.

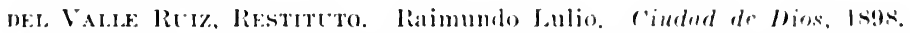

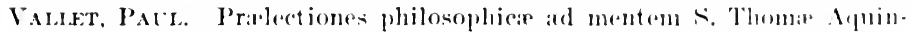
atis. Paris. Roger, 1sa!); n. ed.. 1s!1 ; Span. by (i. Rosis, Bogentat

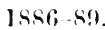

Histoire de la Philosophie. Paris. Istil; 5. ed., lsat.

laidee du heau lans la philosophie de saint Thomas. Parin. losk.

le Kanti-me et le Positivisme, etude sur les fondements de la con. natisance humaine. Paris, 1s8t.

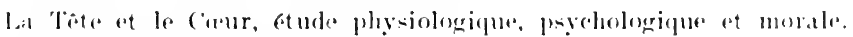
l'aris. Rouger \& rheruovi\%, Is!ll.

La vir et l'heremlití. Paris, Rotaux, ls!le.

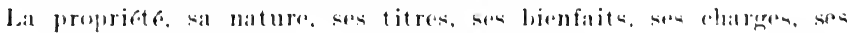
limitations. son avenir. Lyon, Vittr. 1!)oo.

Dien principe de la loi morale. Paric, Bloud \& Barral. 1900.

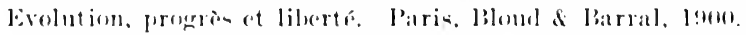

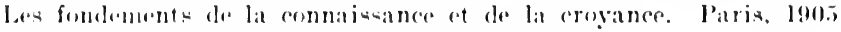

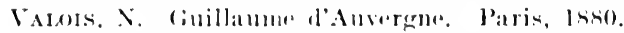

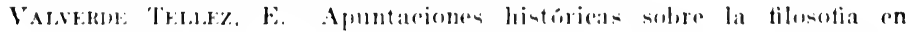

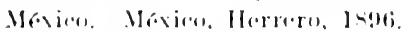

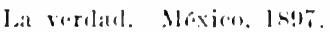

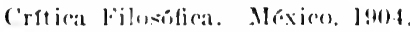

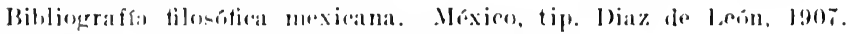

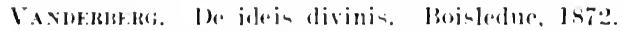

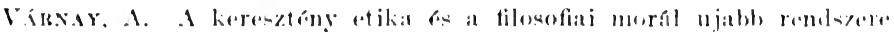
Bndingent, lasm.

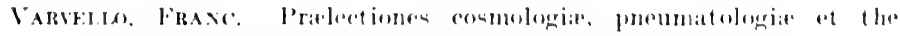
ologia naturalic. Augnte Taturin., off. Salesiana, lsag.

Institutiones philosophicas. Ethiea. Angunt. 'Taurin., 1902.

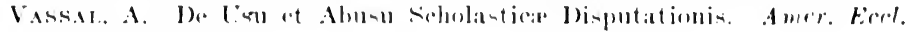
lier., 1900 .

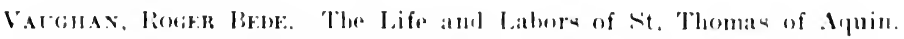
Lonlon, I871-72; Allnny, 187.4 . 
Vatghan, Roger Bede. Life and Labors of St. Thomas Aquinas. Abridged and edited by 1). Jerome Vaughan. 2 ed., New York, 1891.

Veder, G. R. Dissertatio de Anselmo Cantuariensi. Lugd. Bat., 1832. Ventura de Raulica, J. La Philosophie chrétienne. Paris, 1861; Ital., Napoli, 1862; Span., Madrid, 1864.

Venturoli. Del Panteismo e Materialismo nelle scienze naturali. Bologna, 1865.

Vercellone. Di Sant-Agostino e San Tommaso ricongiunti alla odierna filosofia dei maestri cattolici. Napoli, 1864.

Vermeersch, S.J., A. Quæstiones de justitia ad usum hodiernum scholastice disputatie. Brugis, Bryaert, 1901.

Vespignaxi, Arf. Mer. 11 Rosminianismo ed il lume dell'intelletto umano. Studio critico-filosofico. Bologna, 1888.

Dell'intelletto agente e dell'intelletto possibile. Parma, 1892.

In liberalismum universum Doctore Angelieo duce et pontifice Summo Leone XIII trutina. Dir. Thom., 1897-98.

Vigiva, L. Sant'Anseluno, Filosofo. Milano, 1999.

Vir.an, Agustix F. Vocabulario de Términos Escolásticos para la mejor inteligencia de los escritores de la Edad Media, especialmente de Santo Tomás de Aquino (auctore J. M. Zama Mellinio). Traducida y ammentada. Guadalajara, 1879.

a Villafraxca, G. Compendium Philosophize juxta dogmata D. Thomæ, D. Bonaventura et Scoti, ad hodiesnum usum accommodatum. Tonlouse, tip. s. Cyprien, 1899-1901.

Vinfmatx. Les amours, les malheurs et les ouvrages d'Abélard et d'Héloüse. Paris, 1835.

Vinati, .Tosives. Relationum definitio et divisio ad mentem S. Thom:e. Div. Thom., 1890-91.

De principio causalitatis animadversationes criticx. Div. Thom., 1897 .

Natura et genesis principii causalitatis. Dir. Thom., 1898.

De Universalium realitate. Liv. Thom., 1899.

Vincext. 1. Précis de philosophie scolastique. Beyrouth, 1885.

Voger. literarische, historische Notizien iiber den mittelalterlichen Gelehrte von Bealuais. Freiburg-i-B., 1843.

Vogess, S.J., Is. Vraagstukken der Zielkunde. Verstand en Vrije Wil. Ansterdam, 1900.

Vogr. S. Die Physik Roger Bacon. Erlangen, 1906.

VolPI, R. Lectiones philosophia moralis. Roma, 1900.

Vychonf. Beweise für die Existenz (iottes und ihre Geschichte. 1889.

Walker, Jonx. Essay on the Origin of Knowledge according to the Philosophy of St. Thomas. London, 1858.

Walsi, James J. Medieval Cniversities. Rosary, 1907.

The Thirteenth freatest of C'enturies. New York, Cath. Summer sich. Press, 1907. 


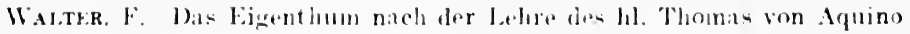
11. d. Socialismus. Freilurg. 1s95.

Ward, Whatam (ibomge. Mill's Denial of Necensary Truth. Mublin Re'., $18 \pi \mathrm{I}$.

Mill's deninl of Free Will. Iublin Rer. Isit.

Appendix on Free Will. Dublin Rer., lsit.

Mr. Mill's Philosophieal Position. Mublin Rer., lsit.

A keply on Necessary Jruth. Dublin Rer., lsit-i.5.

Mill on the Foundation of Morality. Mublin lier., lsiz.

Mill on Causation. Dublin Rer., leiti.

The Reasonable Batis of certitude. Dublin Rer.. lsis.

Free Will. Inblin Rer. lsig.

Supplementary Remarks on Free Will. Mublin Rer., 1489.

Mr. Shadworth Hodgson on Fre Will. Dublin Rer.. Isso.

The rextent of Free Will. Inblin Rer.e lsist.

Philosoplyy of the Theistic controversy. Imblin Ror., liss.

Wrobr, sisox. Der fiottenbeweise ans der Bewegung hei Thomas $v$ A1. auf seinem Wortlaut untersucht. Ein Beitrag zur lert kritik und Erklïrung der summa contra gentiles. Freibura.i.l... Herder. 190:2.

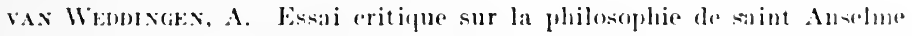
de Cantorbery. Bruxelles, 1si.).

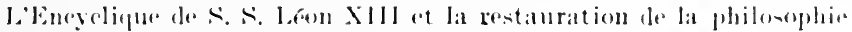
chretionne. liruxelles, listo.

Silloge argumentorum, quibus a Scholar ehristianar Doctoribus veritas humana cognitionis et scientiar certitudo comprobatur. Dir. Thom., lisis.

Albert le Cirand, le mat in de satint Thomas. liruxelles, lsol.

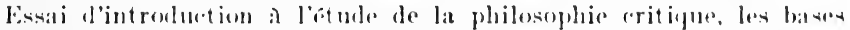

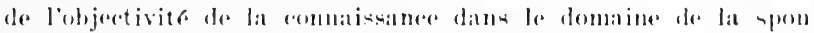
taneite et de la reflexion. Bruxellen. Hayez, lsisel.

Wenofre. Th. M. Anorinumern leo Xlll. iber das Thomatitudium. Jahrb. I'h. sp. Th., lsgti.

Die geitige Bewegung in Anschluss an die Thomas-Eneyclica leos Xill. vom 4 Ang. 1679. Wien, 1s!it.

Wente, Easser. Der Commentar des Mamonides. Arab. Text mit

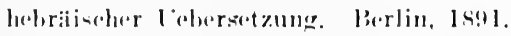

Wercsurar, l. Der Mikrokosmos, ein Angeblick im 12. Jahrh. von dem cordubenser domef ilon Zaddik verfasstes philosoph. Syintem, nach seiner lehtheit untersucht. Breslatu, lasto.

Wras, ('It. Hugonis de Sineto Vietore metholus myatica. Jaris, 1s39.

Wriss, O.P., Aln. M. Die Kunst zu leben. Freiburg i-B., Ilerder, 1900.

Wrass. J. II. Biographien heriblenter jiblischer Golehrten dea Mittel alters. 1. Ifeft: Rabbi Moses ben Maimon. Wien, lstil.

Wrass, K. Veber den begrith der Tugend im allgemeinen nach der I.thre des hl. Thomas $v$ Aquin. Jahrb. Ph. sp. Th., 1s93. 
Werss, M. Ceber mariologische Schriften des Albertus Magnus, primordia nova bibliographiae beati A. M. Paris, 1898 .

Weiss, S. Philo von Alexandrien und Moses Maimonides. Halle, 1884.

Welcil, A. C. Anselm and his Work. New York, Scribner, 1901.

Wexinam, JoHn G. On the Formation of Knowledge. Dublin Rev., 1885.

Werdexicir, E. 1 társadalom és az igazságos munkabéis. Bölcs. Foly., 1896.

A földbirtokjog föbb tételei Aristotelesnél és a ker. böleseletben. Bölcs. Foly., 1902.

Termeszetes Istentan. Györ, 1905.

Werser, Carl. Der heilige Thomas von Aquino. Regensburg, 1859.

Franz Suarez und die Scholastik der letzten Jahrhunderts. 2 vol., Regensburg, 1861; 2. ed., 1889.

Wilhelms von Auvergne Verhältniss zu den Platonikern des 12. Jahrh. (Sitzungsberichte d. kais. Akad. d. Wiss., I873).

Die Psychologie des Wilhelm von Auvergne. Wien, 1873.

Alcuin und sein Jalırhundert. Paderborn, 1876.

Die Psychologie und Erkenntnisslehre des Johannes Bonaventura. Wien, 1876.

Die Psychologie und Erkenntnisslehre des fohamnes Duns Seotus. Wien, I87 7 .

Die Sprachlogik des Johannes Duns Scotus. Wien, I877.

Der Entwickehungsgang der mittelalterlischen Psychologie von Aleuin bis Albertus Magnus. Wien, 1877.

Die Psychologie, Erkenntniss- und Wissenschaftslehre des Roger Baco. Wien, I879.

Die Kosmologie und allgemeine Naturlehre des Roger Baco. Wien, 1879.

Johannes Duns Seotus. Wien, 1881.

Die Scholastik des spiiteren Mittelalters. 3 vol.. Wien, 1881-87.

Die nominalisirende Psychologie der Scholastik des späteren Mittelalters. Sitzber. Akad. Wiss., Wien, I882.

Wetzer, M. Die Lehre des Aristoteles von der Gerechtigkeit und die Scholastik. Warburg, 1881.

Win, I. Ueber die Eehtheit einiger Opuscula des hl. Thomas. Jahrb. Ph. sp. Th., 1906.

Wilkexs, A. Peter Abälard. Bremen, 185.).

Wilks, W. and M. The Three Archbishops. London, 1858.

Wilizms, C. Die obersten Seins- und Denkgesetze nach Aristoteles und den hl. Thomas von Aquin. Philos. Jahrb., 1901.

Die Erkenntnisslehre des modernen Idealismus. Trier, 1906.

Institutiones philosophice. 2 vol., Treveris, 1906.

Winlis, T. F. The Foundation of Philosophy. Dublin Rev., 1902.

Whlmaxy, (). Geschichte des Idealismus. Braunschweig, $1896 \mathrm{fr}$. 


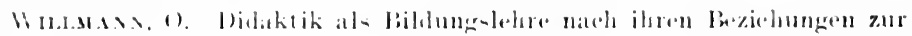

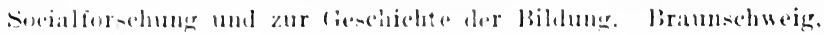
3. (2l.. 1!) 13 .

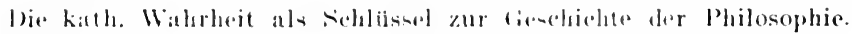
Minclen, l!)!.

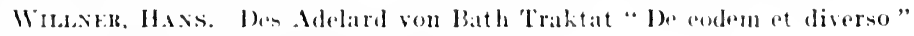
(Be+itriigr+). Miinstar, l!)(3:3.

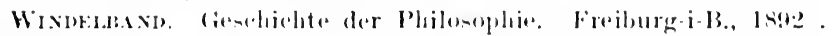

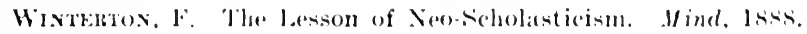

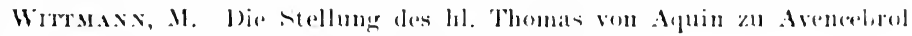
(Beitrige). Minster, Aschendurtr, lsi!t?.

\%um Prohlem der I'tlicht. Philos, Juhrb. la(04.

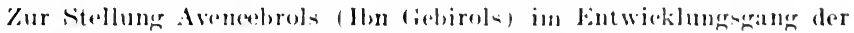
arahischen Philosophie (Beitrige). Miinster, la0s).

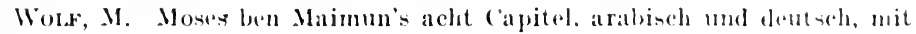
Anmerkungen. I,eipzig, lsti3.

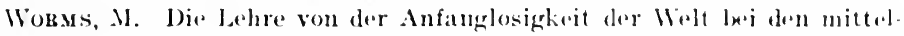
alterlichen arabischen Philosophen des (orients mud ihre bekiimpfungr durch die nrabischen Theologen (beitriige). Miinster. Aschandortf, 1901.

Wotscuke, Th. Fichte und Erigena. Halle, ls!li.

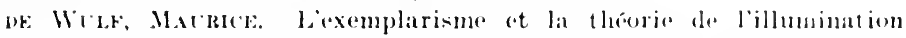

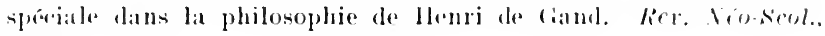
1894 .

Histoire de la philosophie scolastipue dane les l'ays liate lat prin-

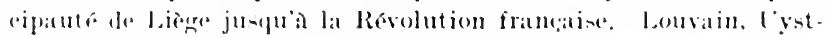
pruyst, Is!).

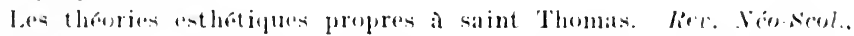
lim !lit.

Etudes sur llenri de Gand. Lenvain. Is!aj.

bitules histerignes sur linthetigue de saint Thomble dipuin. louvain, Is!t).

le probleme des miversaux dams son erobution hintorigue du IX. ill Xll1, sievele. Berlin, 1sitti.

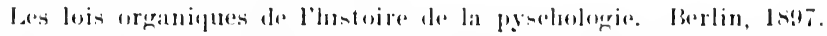

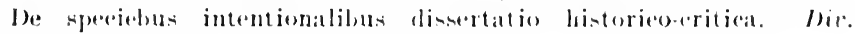
Them., Isit?.

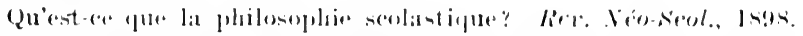

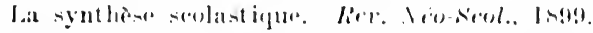

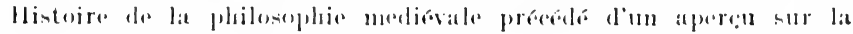

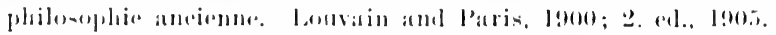

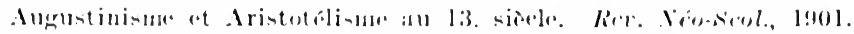

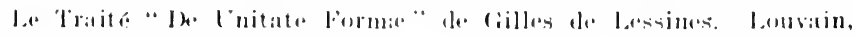
l!)!.

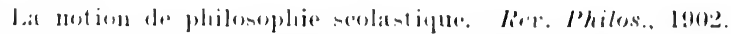

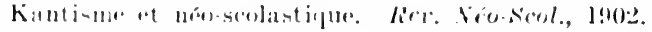


de Wulf, Maurice. Méthodes scolastiques d'autrefois et d'aujourd'hui. Rev. Néo-Seol., 1903.

La décadence de la scolastique a la fin du moyen age. Rev. NéoScol., 1903.

Etudes sur la vie, les auvres et l'influence de Godefroid de Fontaines. Louvain, 1904.

Introduction à la philosophie néo-scolastique. Louvain and Paris, Alean, 1904; Engl. by P. Coffey, London, Longmans, 1907.

Première Lecon d'Esthétique. Rev. Néo-Ścol., 1907.

de Wulf, M. \& A. Pelzer. Les Quatre Premiers Quolibets de Godefroid de Fontaines. Louvain, 1904 .

Zanon, Gianantonio. Prineipii di fisiea secondo la dottrina dellilemorfismo moderno.

Zavilı, M. Polémica. Coleceión de artículos sueltos. Mérida de Yucatán, 1896.

Ziesché, Kunt. Die Lehre von Materie und Form bei Bonaventura. Philos. Jahrb., 1900.

Die Naturlehre Bonaventuras. Philos. Jahrb., 1908.

Zigirara, O.P., T. M. Osservazioni su alcune interpretazioni di G. C. L baghs sull'ideologia di San Tommaso d'Aquino. Viterba, 1870.

Della luce intellettuale e dell'ontologismo secondo la dottrina di S. Bonaventura e Tomniaso d'Aquino. 2 vol., Roma, 1874.

Summa Philosophica in usum seholarum. 3 vol., 1876; s. ed., Paris, Briguet, 1891; Span. by Medina Perez, 1901.

De mente concilii Viennensis in definiendo dogmate unionis anime humanis eum corpore. 1878.

Theses philosophiex. 1881-83.

(Euvres philosophiques. Trad. de l'italien par l'abbés Murgue. 3 vol., Paris and Lyon, Vitte, 1883.

Zıgov, Fr. De seientia media seu Thomismi cum Molinismo coneordia. Gïrz, 1893.

Zur Lehre des hl. Thomas von Wesenheit und Dasein. Jahrb. Ph. sp. Th., 1904.

Ziro, P. Metafisica generale o filosofia prima e fondamentale. Siena, s. Bernardino.

Zuave, Jonaxi. Die Principien der Moral bei Thomas von Aquin. Arch. Gesch. Philos., 1899.

Die psychologisch-ethisehe Seite der Lehre Thomas' von Aquin iber die Willensfreiheit. Jahr. Ph. sp. Th., 1899.

Die Werththeorie bei Aristoteles und Thomas von Aquin. Arch. Gesch. Philos., 1899.

Zoltvixy, J. Az asthetika történetéb̈̈l. Böles. Foly., 1896.

Zokzoli, Emmax. La questione di S. Bonaventura: "De cognitionis humane suprema ratione" conmentata e difesa contro le rosminiane interpretazioni di S. Casara. Torino, tip. Salesiana, 1890. 


\section{INI)ES}

Anriand, Moderate realiom of 25 ; on Roscelin's nominulism, 20; identifies philosophy and theology, 30: condemned by the ('hurch, 23.

Abstraction, Theory of, $110 \mathrm{ff}$; re. jected by Berkeley. 111.

Act and loteney, scholast ic theory of, $4 ! \mathrm{fr}$.

Alarirt tile (imast, on the universal, 24; on induction, 44; on chemical (ombination, 90.

Alsxasiek of llabes's theory of universal matter, !) 4.

Alvaralk, 176.

AMatry of BeNe, condemned by the ('hurch, 23.

Axaxisardek's ronception of philosophy, 28.

Axaximfixes's conception of philosophy, 28.

Axsecs, on relation of faith and reason, 30; ontologrical argument of, $1: 7$.

Amistomes, ground of the preferenee given to in the Middle Ages, l66; his conception of philosophy, 28: his logie, 41; on motion, 50; distinguishes four kinds of causes, fo! : his defini. tion of the soul, 110: on pure arctunlity, 132; his ethical sye tem, $138 \mathrm{fr}$.

Armeracis, on Scholasticiom, Isti.

Atomiom, born in ancient firecer, 8:; molified in modern times, 83; revived hy 1)alton, 105; difficultien of lo:

Attributes of rion, 131 If.: negat tive and positive. 133 ir.

Arcitstrer, identities philosophy and religion, 29; on matter and form, s!?

Avelisg, 230-1, 251.

Azakias, Bhotil:k, $238 \mathrm{ff}, 251$.

Bacox (Fraxcis), his conception of philosophy, 29.

Bacos (Rogke), on induction, 44.

BAF:MKER, 200-1, 251.

BALLERIXI, 172, 252.

BALMEs, philosophical work of. $176 \mathrm{ff} .252$; on substincee, 62.

BАRHERIS, 170, 253.

VAN liECELAERE, 290, 254.

Bfokerar. rejects abitraction. $111 \mathrm{fr}$.

BrkxARD, protects mysticism, 23.

Brsse's contribution to nowsehn, lasticism, 211 2, 25.5; on liomun Thomism, $168 \mathrm{fr}$.

Braxc's contribution to neosede la-tici-m, 206-7, 25ti; on sicho last ic philosophy, 17, 32.

BeEDUT:R, 2:30, 256.

BOSaverte me's theory of uni veral matter, 94; new alition of works hy Franciscans of Quaracehi, 36, 173.

bovisery, condemned by the ('hurch, lis.

Boscovents theory of nature, 83. 101.

losster, Thonism of, 154; on in trornal change in system of doe trine, s.

Bostmorx, on Ariatente's philen ophy, 4!9.

likaxis ontologiom, 232-3.

limickĩo, 188, 258.

bmowxsox's influence upon . Imer 
iean Catholics, 232; on Balmes, 170.

Brïcken, on Aristotle's philosophy, 19.

('AgIGAS, 187-8, 259.

('ARO, on utilitarianism, 191-2.

('ARRA de VAIX, on Scholastic philosophy, 32.

Carrasquilla, 192-3, $2(\mathrm{i} 1$.

Casteleis, 217, 261.

('AtilReis, 198, 261.

Cause, Scholastic theory of, $69 \mathrm{r}$.; efficient, $69 \mathrm{ff}$; final, $78 \mathrm{ff}$; material, $82 \mathrm{ff}$; formal, $82 \mathrm{ff}$; four kinds accorling to Aristotle, 69; Malebranehe's criticism on, 6!)70 ; Hume's criticism on, $70 \mathrm{tr}$.

Chrysostom, Brotiler, 239-40, 263.

('ocosiles, 208, 264.

Comelase, 178-9, 264.

Commer, 199, 264.

Covte's opposition to metaphysics, 47 .

ronceptualiom in the Middle Ages, 24; resembles Kantian philosophy, 25.

IE CONcilio, on pantheism, 240-1.

('oxnnlasc's philosophy introduced into Spain, 175; into Portugal. 183.

Coppexs, $235,264$.

corsomb's contribution to neoScholasticism, 160, 164. 265-6; his opposition to modern philomophy, 9. 13, 164.

comoluey. Scholastic system of, 8.0 $\mathrm{tr}$.

Coesix, on Sidolatic philosophy. 19, 27; his worke on Mediaral philosophy, listi: on Abelard, 25; his philosophy taught in Fremeh Catholie seminaries, 203.

('RIsuls, on foundation of moralit $y, 137$.
Cinie's scientific achievenents, 106.

DaLTox revives hypothesis of atoms, 105.

DARWIN's natural selection and the design-argument, 129-30.

David of Dixaxt condemned by the church. 23.

DedMAs, 210-1, 268.

Democmitrs. regarded as founder of atomistic system, 82.

Dexifle's works on Middle Age's, $200,265$.

Descantes, reuarded as a Scholastic by Picavet, 2; on sub. stance, 61, (5.5; his philosophy taught in French Catholic seminaries, 203 .

Design-argment, $129 \mathrm{fr}$.

DEwer, on Scholastic philosophy, 2.5. 28.

Dinerot, on Duns Sicotus, 18.

Diniot's contribution to neo-Sicholastici-m, 211, 269; on Kanti-m and Hegelianiom, 12.

Directivity, Hemslow's theory of, so.

Domet de Vorges, 204-5, 269.

Driscols, contribution of to neoScholasticism, $241 \mathrm{fr} . .270$; on Kant. 242; on Royee's conception of God, 243.

bixs scotes, prowes existener of primordial matter, $8 \mathrm{~s}$; his division of the materia prima, 94 ; juilged ly 1)iderot, 18; contrasted with Thomas Aquinas, 2.5 .

Dynamism, its theory of nature, 83; Tait's objection to, 101; defieiency of, 101.

Efficiency, very different from eontaut conjunction, $75 \mathrm{mr}$; has 
met two elatures of oplements.

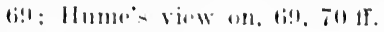

Flatide sehowl, denied tha esi-t rnep of nution, int.

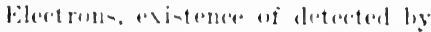

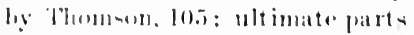
of all material being- lit, lis. 111.) 11 .

Encyelieal ". Eterni Patri-," 162.

Eternity explatined, 133.

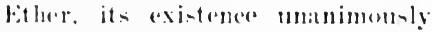
allimed by phroveists. 83; theory of strengthened by ex proments of Maxwell. 102; of 1lert\%, 10:2: inherent eomititution of. 103: repenerers view on, 103: Kelvin on, 103: Larmor on, 104: Iondge on, 104, 10.5; Whethatm on, 103: Véronnet on, 103.

butenoniom of Scholantice ethical rytem. 13ti.

PABRES's (ontrilution to neoscholat icion, 201.), 273: on motion, 50): (1) matter and form, sti, !1: on chental (ommhination, !1], 10!!.

Fichte, subtlety of, 20 i.

Final (at1-r, Totr.

Folstiklte, 213, 275.

Form, Subtantial, scholantic theory of, sit tl.. 4.5 If : properties of, ati: alneerl ont of the futency of mattrer. Jo6): moditieations on the theory of, los: plurality of forme in llenry of Ghent, !s: in louns sontur, !!! : in Laminc. ('onninke, Ma!r, !!?.

Forma ('orporeitatio, !s !)

Frendill, doctrine of definel.

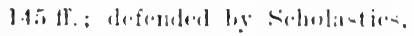
14ti defined by kint, I fi.

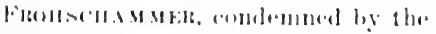
churets, 1:.

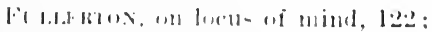

on st. Thomats's determinism, $1+i$.

(iskefise enentribution to nen-

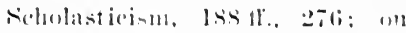
spanioh philusoluy lit s.

Gakmalr. 207. 2iti.

(inkat, llexis or, his destrime of plurality of forms. !s.

Gistums's eontribution to nenSeholasticinm, 195, 20̈: his letinition of matter and form, sti.

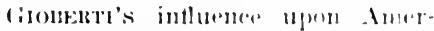
ican ('atholies. 2:3:2.

Ged, proofs of exintenere of 127 tf.: ontological aremument, 1:2: ar gument from the moral law, 127 Ir.: argument from univer-al consent, 1.2s: argument from de-ign, l2!); metaphy-ieal atronment. 130): attrilutes of. $131 \mathrm{ll}$.: elernity of, 133, 1.52: inmutiahility of 1333 : infinity of $1: 31 \mathrm{ll}$.: unity of, 13:2 : simplicity of. 1:32. 135: inmon-ity of, 133: knuwlodge of. 134: will of, 134: omnipotenee of, 134: preacienere of, 1.50 $\mathrm{tr}$.

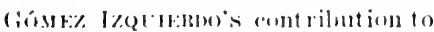
neor-seholatitioin, 1sl, 27!): on (omplas, 179.

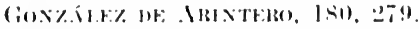

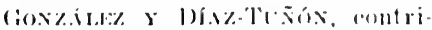
bution of to neosefollatioinn,

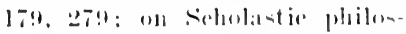
"phy, 32: on Father Ventur., 1.ti; on sameverinu, lis.

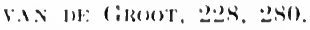

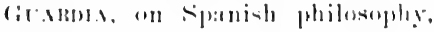
17.4 .

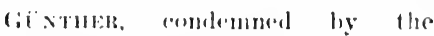
('hureh, le, l!lti.

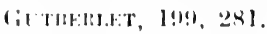

Happinas, nature of in srintotle, 110. 
TlARPER, 228-9, 282-3.

Haureau's definition of Scholastic philosophy, 14; on Scholastic philosophy, 19; on problem of universals, 20 ; on causes of downfall of Scholastic philosophy, 153; his works on Mediaval philosophy, 156.

Hedonism, contrasted with Scholastic ethical system, 138; criticized, 141 ff.; criticized by Ming, $236-7$.

Hegel, on Scholastic philosophy, 19,27 ; on substance, 62 ; on adequate knowledge of God, 126 ; on divine nature in old metaphysies, 134; readmits ontological argument, 127 ; compared to St. Thomas, 12; influence of upon Catholic philosophy in Germany, 196.

Hexslow's theory of directivity, 80.

Hermes, condemned by the Church, 12,196 .

IIERNÁNDEz y FaJarNes, 180, 283.

Невтz, scientific experiments of, 102.

HiLL, 233, 284.

Hobres, on foundation of moralit $y, 137$.

D'HLLST, 212-3, 286.

HrME, on substance, $55 \mathrm{ff}$, 64; on efficiency, $69,70 \mathrm{ff}$; on simplicity of soul, 116.

IBN ('ABBIROL's theory of universal matter. 94.

Idea and Plantasm, confused by Locke, 111; nature of, 111-3.

Immensity of (iod, 133.

Immutability of God, 133.

Induction. in the Middle Iges, 44; regarded as fundamental by Mill, 42; in neo-Scholastic logie, 45.
Infinity of God, $131 \mathrm{ff}$.

Intellect and Sense, essential difference of, 120 .

Taxtiks, on neo-Scholasticism, 3J. Jorix, 233, 287-8.

KAnT, regarded as a Scholastic by Picavet, 2; whether his philosophy can be interpreted from a Christian standpoint, 11 ; on metaphysics, 47 ; on substance, 61,65 ; on ontological argument, 127 ; on moral character of our acts, $144 \mathrm{ff}$; influence of in Spain, 175; influence of upon Catholic philosophy in Germany, 196.

Kacfmaxx, 201, 288-9.

Kelvix, on ether, 103.

KLEUTGEN's contribution of to neo-Scholasticism, $196-7,290$ : principles of knowledge of, 197 .

LARMor, on ether, 104.

LeIbNiz, on substance, 61, 65.

LeMos, 181, 293.

Leo XIII. Cf. Pecci.

LEPIDI's contribution to neo-Scholasticism, 215,293 ; refutes ontologism, 215 .

LEc clpPL', father of atomism, 82. LIBERATORE's contrilution to neoScholasticism, 167, 293-4; on chemical combination, 90.

Locke, regarded as a Scholastic by Picavet, 2; on formation of names, 15; on substance, 53 ff.; philosophy of introduced into Spain, 175; into Portugal, 183.

Lomge, on ether, $104,105$.

Logic, Scholastic system of, $41 \mathrm{fr}$; a complete system in the hands of Aristotle, 4l; Mill's contribution to, 42 .

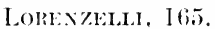


Inusain, In-tifute of Philonteply of, its contribution to meos-s(chorlateticism, 22l\% tl.: its scientitic -pirit, fol: favoralely jullemel ly liene, ltis; reforms which chararturize the Institute, 2ls!: it = prodignious suceosis, 2.20.

Mact)oxin, 247 s. 235 6.

M.MHM:1Ms, Iss, 2utt.

Manras's antribution to neo-

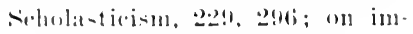
murtality of the solll, ]20).

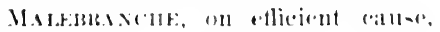
(i).

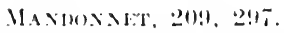

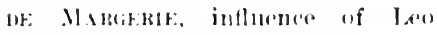

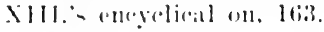

HE: M131., 171, 2!).

MorTf, influrner of an simi-h thinking, 17s.

Matter, (non-titution of acourding (i) modern -rioner, $100 \mathrm{11}$.

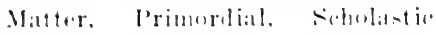
theory af, st tl: propertien of. al: divisions of, !12: monlifieat tions on the therety of, los.

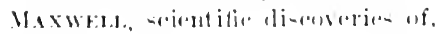
1112.

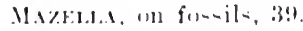

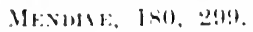

Mrorsure Y Presyo, on sianish philumeley, 17.4.

Mraseres, philuenphical work of. 2ls tr. 2uts: on hi-torioal -tud. i..., 34: on metapliysicen, f6: an tinal rint-r.

Metaphysical aremment, 1:30 1.

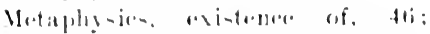
origin of the workl, fti: letinesl

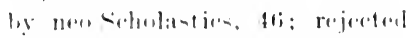
1,y poitivi-m, 17: ly Kant, 17:

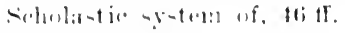

M11.1.5., 21:2, :301.

Mr1., signitiranere of his ". Sy-trm of longe." 42: on syllogiom, 43: an -luh-tance. it) tf. : on technical linguage of Probulation, 111.

M1Ni, 2:36i 7, 301.

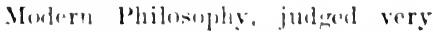
meveloly ly cornoldi, !1, 13, lit: by de Maria, 17I: ly ('agigass. list: by lorentelli, ltis: hy Nammus, zon: comblemmed by ()rte y latra, Iso); despised lig ()Brien, 2\$1; 7 .

Millstrk, Isti, lati.

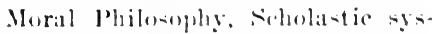
trin of, listiff; contrated with Kantian -y-tem, $14 t 1 \mathrm{~T}$.

Moral prouf of liod's exintence. $1: 7$ if.

Morality, grout qua-tion of. 137: based on external principle. $13 \% 11$.

Motion, exi-tence of loniod by Fleaties, 50; Nowtumian laws

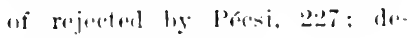
fined loy fares, st).

Mextit is, 1sti, 302.

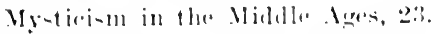

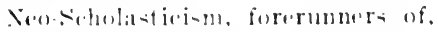
1.i3 tl. : oplenition to the worle 34. 35: moner-al allorener of (1) Mhomal- Aquinas, 31: moditiritlions it has intromlueed on the philusuphy of the Minllle. Ager. 37 ; important contributions of (1) stmly of mombru philosephiral litrrature, :3!): and serentific studiers, 3!): its -y-tem uf

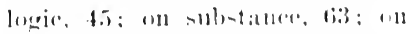
ontolongeal aremment, 12: ; meral aremment, las; on metat physical aremument, 130.

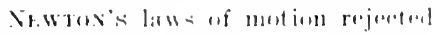

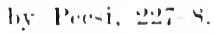

Nominali-1n, la:ale to matreriali-nl, 21: alan to ny-ticisut. 2l. 
Nys's contribution to neo-Seliolasticism, 22.2, 304; on matter and formin, 85 .

O'Briex's contribution to neoScholasticism, $245 \mathrm{fr}$. . 304; despises modern philosophy, 246-7.

Oecasionalism, eonsiderations urged against, 70 .

Omnipotence of God, 134.

Ontological argument discussed. $127 \mathrm{ff}$; rejected by st. Thomas. 127.

Ontologism in Bolgium, 215; in the Cnited States, 232-3; refuted by Lepidi, 215; condemned by the Church. 215.

OrTí Y LARA's eontribution to neoScholasticism, 179-80. 304; on historical studies, 38 ; condemns modern philosophy, 180.

OвтіZ, 194-5, 305.

Pantheism, the outcome of realism, 22: in the Middle Ages, 22; condemned by the Church, 12, 23 ; de Concilio on, 241.

PAQUeT, 247, 306.

Pallsen, on Thomistic revival, 1.

Peccl (Leo Xlll.), sympathizes with the Thomistic revival, 159 ; is elected pope, 160; imposes scholastic philosophy on Catholic world, 162 ; founds Institute of louvain, 218.

Pecsa's eontribution to neo-feholasticism, $2.25 \mathrm{fr} ., 307$; his theory of matter and form, $226-7$; rejects Newtonian laws of motion. 227.

Penachere, 207, 307.

Pesc' H, 198, 307.

Pfelfer, 202, 308.

Phantasm and laleal. confused by locke, 111: nature of. $111 \mathrm{fl}$.
Philosophy, meaning in ancient times, 28; its essential eharac. ter, 189 ; defined by speneer, 29 : identified with theology by st. Angustine, 29; by Scotus Erigena, 30; by Abelard, 30; discriminated from theology by Thomas Aquinas, 31.

Piat, 213, 309.

Picavet's philo-ophical work, 213-4. 309-10; on Thomistic revival, 2 ; on Scholastic philosophy, 19.

P'IDAL Y Mon, 180, 310.

Plate, realism of, 2:2 ethical system of, 138.

Polaxd, 234-5, 311.

Positivism, rejects metaphysics, 47.

Potency, Cf. Act.

Pragmatism, weleoned by French Catholics, 6.

Predestination, doctrine of in st. Thomas, $150 \mathrm{ff}$.

Prescience of God, $150 \mathrm{fr}$.

Provt, on atomism, 105 .

Psychology, Scholastic, 110.

Purpose, what old Scholastics meant by, 51.

Radio-aetivity, scientific observations on, $106 \mathrm{fl}$.

Realism. professed by Plato, 21; moderate form of, $23,24$.

DE REgxox, 209-10. 314.

REMesat, on Vediaral philosophy, 156; on Abelard, 25.

RESTREPO, 19:3 4. 314.

RickabY's emotribution to nemScholasticism, 230, 315: on Hume's philosophy, 58.

lisera. on spanish philosophy. 174.

lomesplerse. regarded as a Schola-tic by Picavet. 2. 
lioman Thomints, serelely judered

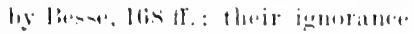
uf - rience, 3!!.

lion.11:1:, 2:37 \&, :311.

liandul, 1st. 311i.

lios(1.1.1. m the unis(r-all, 20, 21 :

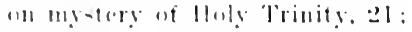

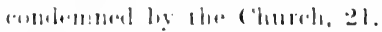

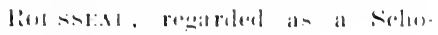

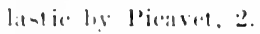

ling(1: an my-tic.i-m, 21 : his promit

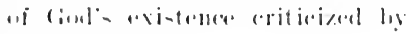
1)rincoll. 213 .

li1 sit, 2:31, 314.

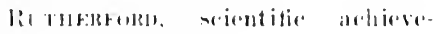
munti of. 106.

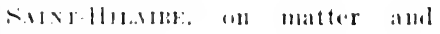
formu, sti.

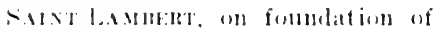
m!orality. 1:3\%.

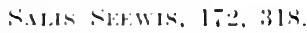

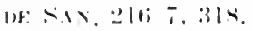

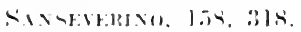

S.NTHL.1, lij, :31!1.

लिमान11, 1\%1. 3200.

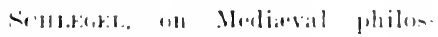
mhly, liti. 1!li.

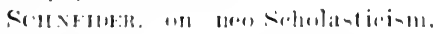
$3 ., 2(11)$.

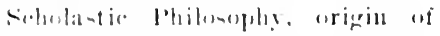
the word -cholat-tic. 1t: defined in telln= of it - language meth. wh. 2⿰氵 definol by it rolation to thenlenes. 27: identitiol with theoluen. 27: detimed ly Dewey.

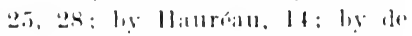
Mulf. 17; by Blane, 17: ly M.lw.r, 27: ly Tyrrell, 2x: ly

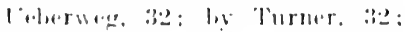
i. primatrily and andentially the

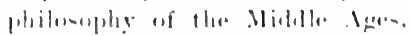

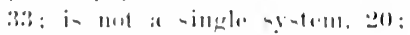
it - harmony with ratholic thenl

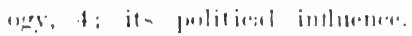

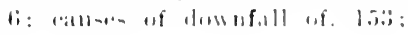

atuan uf its revival, $7:$ forrorum ner- of it revival, $153 \mathbb{1 r}$; its -y-tem of logice 41 if. : its meta. physice. flitr.: its theory of -uhatance. 52 tr.; its theory of

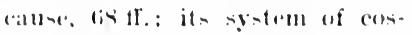
moluger siente: its theory of matter and form, se IT. ; its poyelowlegre 110 If.: it i natural the ulacy. letitl.; its ryotem of 1161\%als, $1336 \mathrm{ml}$.

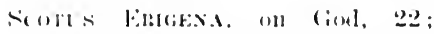
indentifies philosophy and theol. reye 30: combemmed ly the ('hinroli, $2: 2$.

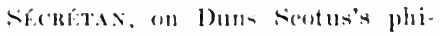
losephy. i: on st. Thomas's de10rmini-m. 147.

Selection. Natural and the denignaremuncut, 1:29-30.

sillar and Intellect, essential difforemere af, 1:00.

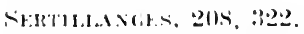

Simplicity of (ionl, 1:32. 1:35.

Sixm1111, Ist, 321.

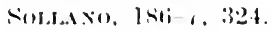

Soml, detimed by Ariatotle. 110: nature of, 1l.itl.: intrinsically independent of lowly, 115: simplicity of, Il.i; -prirituality of, listr.: immortality of. 1:20: locilis uf, lel fl.

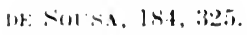

cirescres conception of philu ophy, 2!!: apponition of to meta plis-ice, t5; on ether, 10:3: on

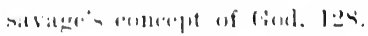

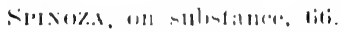

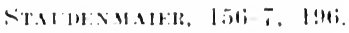

slickl. 1!17, 83:5.

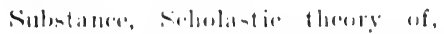

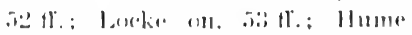

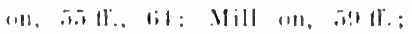
|). atartan oll, lil, tis: lacilniz un.

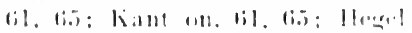


on, 62; Balmes on, 62; Sinoza on, (iti.

Syllogism, nature of, 42; Mediaval philosophy on, 26 ; Mill on, 43 ; praised by Leibniz, 26.

Taine, on Scholastic philosophy, 19.

TAIT, on dynamism!, 101.

Talamo, $165 \mathrm{ff} ., 327$.

TAPAREILI, $172,328$.

'Tertillan's system of philosophy, 29.

'Thales's conception of philosophy, 28 .

Theology, natural and revealed, 126 ; its relation to philosophy, 10, 31 ; identified with philosophy by St. Augustine, 29; by Seotus Frigena, 30 ; by Abelard, 30 ; discriminated from philosophy by Thomas Aquinas, 31.

Thomas Aquinas's doctrine of unity and immutability of truth. $S$ : on relation of philosophy and theology, 31; on primordial matter, $8 \pi$; on loeus of the soul, 124; on God's ubiquity, 125; on Anselm's ontological argument, 127 ; on pure aetuality, 132; on immensity of God, 133; on simplicity of God, 135; and free will, 147 Il.; on prelestination, 150 $\mathrm{fl}$. ; obsolete doctrines of, 35: contrasted with Duns Seotus, 25: Leonine edition of his works. 36 .

Thomsox, diseovers electrons, 10.).

Traditionalism, eondemned by the Church, 13.

Truth. its unity and immutability according to sit. 'Thomas, 8.

TrRxer's eontribution to noo-sicholasticism, 244, 329; on Scholastic plilosophy, 32 .

Trrkrla, on siholasticism, 28.
Lbaghs's influence in Belgium, 215.

Leberweg, on Scholastic philosophy, 32 .

Unity of God, 132.

Universals, conceptualists on, 24; Hauréau on, 20 ; de Wulf on, 20 ; Albert the Great's solution of the problem of, 24 .

'Rríblru's contribution to neoScholasticism, $181 \mathrm{fr} ., 330$; his strictly scholastic method, 37 ; on sense and intellect, 119; on immortality of the soul, 121.

Vacant, 211, 330.

VACHERot, on act and potency, 49. VAllet, 205, 331.

Valuerde Téluez, 190-1, 331.

Ventura, 15\%.

VÉroxiet, on ether, 103.

Voltaine, regarded as a Scholastic by Picavet, 2 .

Weber, on Scholastic philosophy, 27.

VAN WeddngeN, 216, 333.

Werser, 200, 334.

Wintilam, on ether, 103.

Will, freedom of, $145 \mathrm{fl}$.

William of Cimampatx, connected with Mediaral mysticism, 23 .

Woondridie, on vital problem of metaphysies, 47.

DE WLLF's contribution to neoScholasticism, 221-2, 335; his definition of Scholastic philosophy, 17; on problem of universals, 20; on historical studirs. 38; on Seholastic system of ethics, 136.

Zetuer, on Scholastic philosophy, 32.

ZiGiLiARA, 164-5. 336. 


\section{THE COLUMBIA UNIVERSITY PRESS}

Columbia University in the City of New York

Books fullished at net prices are sold by tooksellers eieryithele at the adier. tised net frices. When delicered from the pwblishers, carriage, either postate or expessage, is an extra charge.

AN INTRODUCTION TO SYSTEMATIC PHILOSOPHY. By Walter 'T. Makvis, Ph.l)., Assistant Professor of Philosophy, Princeton University. 8vo, cloth, pp. xiv +572. Price, $\$ 3.00$ net.

ANCIENT IDEALS. A study of Intellectual and Spiritual (irowth from Varly 'limes to the Establishment of Christianity. By HWRr OSBORN 'TAYlok. In two volumes. Sro, cloth. Vol. I, pp. $x i+461$. Vol. II, pp. vii +430 . Price, $\$ 5.00 \mathrm{net}$.

THE PRINCIPLES OF SOCIOLOGY. An Analysis of 'The Phenomena of Association and of Social ()rganization. By Frankils HeNry (ildulncis, LI..I), Professor of Sociology, Columbia Lniversity. 8ro, cloth, pp. xxvi+476. Price, $\$ 3.00$ net.

CRIME IN ITS RELATION TO SOCIAL PROGRESS. liy Aктhi'k (ifevelanil Hali, P'h.l). Svo, cloth, pl). 427. P'rice, $\$ 3.50$ nct.

EFFICIENCY AND RELIEF. A P'rogramme of social Work. By EIWARD T. INisine, I.I.I)., Schiff Professor of Social Economy, Columbia Lniversity. $12 \mathrm{mo}$, cloth, IP. viii +45 . Price, 75 cents net.

POLITICAL PROBLEMS OF AMERICAN DEVELOPMENT. By AllikeT SHAW, L.I.I), Editor of the Rerieze "f Recticu's. 12 mo, cloth, pp. vii +268 . Price, $\$ 1.50$ net.

CONSTITUTIONAL GOVERNMENT IN THE UNITED

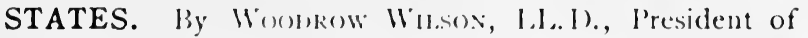
l'rinceton ('niversity. $12 \mathrm{mo}$, (loth, pl). vii +236 . P'rice, $\$ 1.50 \mathrm{net}$.

THE PROBLEM OF MONOPOLY. A Study of a (irave l)anger and the lleans of Averting it. by Jons liatks ('ikkk, l.l.1)., I'rofessor of l'olitical Economy, Columbia liniversity. 12mo, cloth, plp. vi+12S. Price, \$1.25 net.

\section{Till: MAC.MHLI.IN ComISNY, Agents 64-66 FIFTH AVENUE, NEW YORK}




\section{THE COLUMBIA UNIVERSITY PRESS}

Columbia University in the City of New York

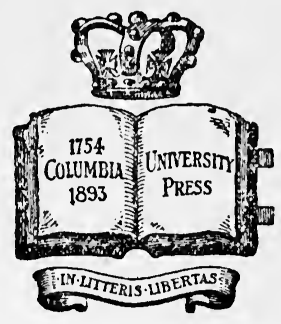

The Press was incorporated June 8,1893 , to promote the publication of the results of original research. It is a private corporation, related directly to Columbia University by the provisions that its Trustees shall be officers of the University and that the President of Columbia University shall be President of the Press.

'The publications of the Columbia University Press include works on Biography, History, Economics, Education, Philosophy, Linguistics, and Literature, and the following series :

Columbia University Biological Series.

Columbia University Studies in Classical Philology.

Columbia University Studies in Comparative Literature.

Columbia University Studies in English.

Columbia University Geological Series.

Columbia University Germanic Studies.

Columbia University Indo-Iranian Series.

Columbia University Contributions to Oriental History and Philology.

Columbia University Oriental Studies.

Columbia University Studies in Romance Philology and Literature.

Blumenthal Lectures. Hewitt Lectures.

Carpentier Lectures. Jesup Lectures.

Catalogues will be sent free on application.

The Macmilian Company, Agents 64-66 FIFTH AVENUE, NEW YORK 



St. Michael's College Library

\section{PHONE RENEWALS}

9 $926-7114$

Due date:

DEC 101997

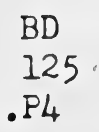


